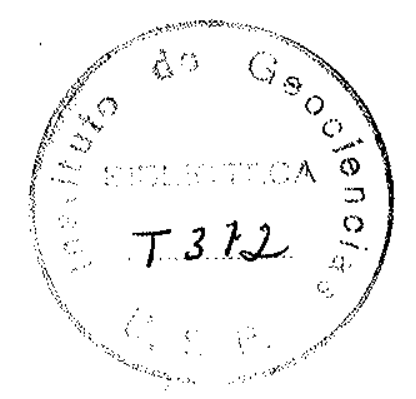

\title{
CONDIÇÕES DE METAMORFISMO DE BURITIRAMA, PARÁ E SERRA DO NAVIO, AMAPÁ
}

\footnotetext{
Dissertação de Mestrado apresentada ao Departamento de Mineralogia e Petrologia do Instituto de Geociências da Universidade São Paulo.
}

Orientador :

Prof. Dr. José Vicente Valarelli

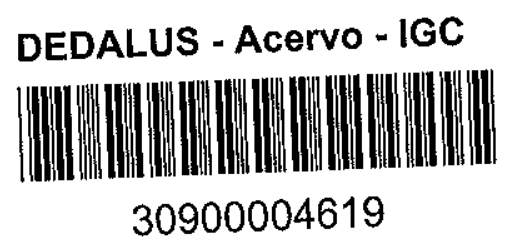


INDICE

RESUMO

CAPITULO I

INTRODUÇAO

CAPITULO II

4

MATERIAIS E METODOS

$\begin{array}{ll}\text { CAPITULO III } & 7\end{array}$

JAZIDA DE MANGANES DE BURITIRAMA 7

III - 1 - ASPECTOS GEOLOGICOS DE BURITIRAMA

III - 2 - ESTUDO DOS PROTOMINERIOS E ENCAIXANTES DE BURITIRAMA 13

$111-2-1$ - GENERALIDADES 13

$111-2-2$ - DESCRIÇÃO DE FUROS DE SONDA 15

III $-2-2-1-$ Furo B5-10 15

III $-2-2-2-$ Furo B5-22 19

III $-2-2-3-$ Fuxo B5-14 : 19

$111-2-3-$ TIPOS DE PROTOMINERIOS 20

III - 3 - MINERALOGIA DOS PROTOMINERIOS 23

$111-3-1-$ CARBONATOS 23

$111-3-2-$ ṔIROXMANGITA 24

$111-3-3-$ RODONITA 27

$11|-3-4-C L I N O P| R O X E N I O S$ MANGANESIFEROS 30

$111-3-5$ - TEFROITA 30

$111-3-6 "$ - ANFIBOLIOS MANGANESTFEROS 33

$111-3-7$ - GRANADAS 34

$111-3-8$ - FLOGOPITA MANGANESIFERA 34 
JAZIDA DE MANGANES DE SERRA DO NAVIO

IV - 1 - ASPECTOS GEOLOGICOS DE SERRA DO NAVIO

IV - 2 - ESTUDO DOS PROTOMINERIOS E ENCAIXANTES DE SERRA DO NAVIO

IV - $2-1$ - GENERALIDADES

IV - $2-2-$ DESCRIÇAOO DE FUROS DE SONDA

$$
\text { IV }-2-2-4 \text { - Outras Amostras }
$$

IV - $2-3$ - TIPOS DE PROTOMINERIO

IV - $\dot{3}$ - MINERALOGIA DO PROTOMINERIO

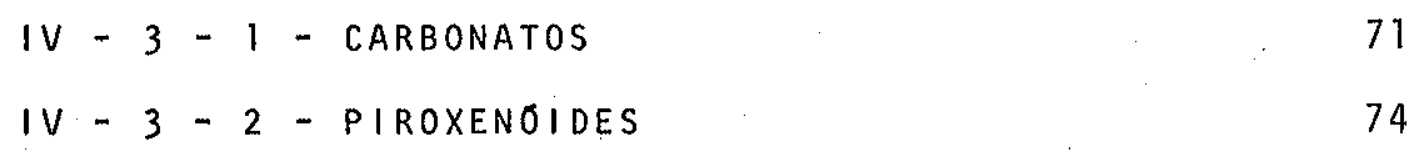

IV - $3-2-$ PIROXENOIDES

IV $-3-3$ - TEFROITAS

IV - $3-4$ - ESPESSARTITA

IV - $3-5$ - FlOGOPITA MANGANESTFERA

IV. $-3-6-$ ANFIBOLIOS

IV - 3- 7 - MINERAIS METALICOS E ACESSORIOS

DISCUSSAO DOS RESULTADOS

$V$ - 1 - CONDIÇðES FISICO-QUIMICAS DO METAMORFISMO DE BURTTIRAMA

$\mathrm{V}$ - 2 - CONDIÇOES FISICO-QUIMICAS DO METAMORFISMO DE SERRA DO NAVTO 


$$
\begin{aligned}
V-3 \text { - PARTIÇAO DE ELEMENTOS } \\
V-4 \text { - CORRELAÇÃO ENTRE O METAMORFISMO, A GEOTEC } \\
\text { TÔNICA E A GEOCRONOLOGIA }
\end{aligned}
$$

\section{TABELAS}

Tabela I - Anālises de microssonda de carbonatos de protominërios de Mn de Buritirama

Tabela II - Anālises de microssonda de piroxenóides de protominérios de Mn de Buritirama

Tabela III - Análises de microssonda de clinopiroxënios de protominërios de Mn de Buri tirama

Tabela IV - Anälises de microssonda de tefroitas de protominérios de Mn de Buritirama

Tabela $\quad V$ - Anālises de microssonda de anfibólios de protominerios de Mn de Buritirama

Tabela VI - Anălises de microssonda de espessarti tas de protominërios de Mn de Buritirama

Tabela VII - Anālises de flogopitas manganesīferas de protominérios de Mn de Buritirama

Tabela VIII- Dados ópticos de piroxenóides e clino piroxēnios de protominérios de Mn de Buritirama

Tabela IX - Dados ópticos de olivinas de protominërios de Mn de Buritirama

Tabela X - Anālises de microssonda de carbonatos de protominérios de Mn de Serra do Na vio 
Tabela XI - Anălises de microssonda de piroxenōi des de protominërios de Mn de Serra do Navio

Tabela XII - Anālises de microssonda de tefroitas de protominerios de Mn de Serra do Navio

Tabela XIII - Anälises de microssonda, de espessarti tas de protominërios de Mn de Serra do Navio

Tabela XIV - Anālises de microssonda de flogopitas manganesíferas de protominërios de $\mathrm{Mn}$ de Serra do Navio

Tabela XV - Anälises de microssonda de anfibölios de protominerios de $M n$ de serra do Navio

Tabela XVI - Dados ōpticos de piroxenöides de protominērio de Mn de Serra do Navio

Tabela XVII - Dados ópticos de olivinas de protomine rios de Mn de Serra do Navio

\section{FOTOS}

Fotos 1 e 2 - Calco xistos encaixantes de Buritirama

Fotos 3 e 4 - Märmores calcossilicäticos encaixantes de Buritirama

Fotos 5 a 10-Protominërio - Braunita märmores de Buritirama

Fotos 11 a 18- Xistos. calcossilicāticos encaixantes de Buritirama

Fotos 19 a 21-Protominērio - märmores calcossilicä ticos de Buritirama 
Fotos 22, 23 e 24 - Protominério - piroxmangita märmores de Buritirama

Foto 25 - Protominērio - mārmore manganesífero de Buritirama

Foto 26 - Protominērio - braunita märmore de Bu ritirama

Fotos 27a, 27b, 28 e 29 - Protominērio - tefroi ta märmore de Buritirama

Foto 30 - Protominērio - piroxmangita märmore de Buritirama

Foto 31 - Encaixante calcossilicätica de Buriti rama

Foto 32. - Protominērio - braunita märmore de Buritirama

Fotos 33 a 41 - Xistos encaixantes de Serra do Navio

Fotos 42 e 43 - Protominērio - märmores mangane siferos de Serra do Navio

Fotos 44 a 47 - Sillimanita xistos encaixantes

de Serra do Navio

Fotos 48 e 49 - Encaixantes calcossilicäticas de Serra do Navio

Fotos 50 a 53 - Protominērio - tefroita märmores de Serra do Navio

Fotos 54 e 55 - Protominērio - piroxmangita mär mores de Serra do Navio

Fotos 56 a 59 - Protominērios sỉlico carbonäticos e märmores silicäticos de serra do Navio

Fotos 60 a 63 - Encaixantes metape1iticas (xistos) de Serra do Navio

Foto 64 - Encaixante calcossilicática de Serra do Navio

Foto 65 - Xisto encaixante de Serra do Navio

Foto 66 - Protominērio - sīlico carbonātico de Serra do Navio 
Figura 1 - Mapa geológico da região de Serra dos Carajās

Figura 2 - Mapa geológico da Serra de Buritirama

Figura 3 - Mapa geológico do corpo de minërio B-5

Figura 4 - Seção geolögica $200 \mathrm{~N}$ do corpo de mine rio $B-5$

Figura 5 - Perfil litológico esquemätico do furo de sonda.B5-9 e do furo de sonda B5-10

Figura 6 - Solução sōtida no sistema $\mathrm{CaCO}_{3}-\mathrm{MnCO}_{3}$

Figura 7 - Diagrama triangular em porcentagem molar de $(\mathrm{Mn})-(\mathrm{Ca})-(\mathrm{Fe}+\mathrm{Mg})$ de carbonatos, rodo nitas, piroxmangitas, clinopiroxēnios e tefroitas de amostras de protominērios de manganês de Buritirama

Figura 8 - Mapa geolögico do distrito de Serra do Navio

Figura 9 - Pefil geológico da jazida C-2 - Seção $14+20$

Figura 10- Perfil geológico da jazida F-12. Seção $7+60$

Figura 11- Diagrama triangular em porcentagem molar de $(M n)-(\mathrm{Ca})-(\mathrm{Fe}+\mathrm{Mg})$ de carbonatos, rodo nitas, piroxmangitas e tefroitas de amos tras de protominērios de manganēs de Ser ra do Navio

Figura" 12- Diagrama isobärico $\mathrm{T}-\log \mathrm{fO}_{2}$ para o sistema $\mathrm{Mn}-\mathrm{C}-\mathrm{Si}-\mathrm{O}-\mathrm{H} . \mathrm{PT}=2.000$ bars; $\mathrm{X}_{\mathrm{CO}_{2}}=1$

Figura 13- Diagrama isobärico $\mathrm{T}^{-\mathrm{X}_{\mathrm{CO}}}$ para o sistema CaO-MgO-SiO ${ }_{2}-\mathrm{H}_{2} \mathrm{O}-\mathrm{CO}_{2}$ à vărias pressões to tais

Figura 14- Densidades criticas de $\mathrm{CO}_{2}\left(\mathrm{~g} / \mathrm{cm}^{3}\right)$ e tempe raturas de homogeneização de 394 inclusões fluidas em cristais de quartzo. 
Figura 15 - Diagrama isobārico $\mathrm{T}-\mathrm{X}_{\mathrm{CO}_{2}}$ para o sis tema $\mathrm{CaO}-\mathrm{MgO}-\mathrm{SiO}_{2}-\mathrm{H}_{2} \mathrm{O}-\mathrm{CO}_{2} \overline{\mathrm{a}} \mathrm{Pf}=1 \mathrm{~Kb}$ e $P f=5 \mathrm{~Kb}$

Figura 16 - Diagrama $P-T$ : reações metamörficas em rochas peliticas

Figura 17 - Diagrama $P-X_{F e 0}$ de granadas e cordier $\underline{i}$ tas coexistentes a $700^{\circ} \mathrm{C}$

Figura 18 - Diagrama $P-T$ para a associação cordierita + almandina + sillimanita + quartzo

Figura 19a- Relação $\mathrm{Ca}^{2+} / \Sigma \mathrm{M}^{2+}$ entre carbonatos e es pessartitas coexistentes. Buritirama.

Figura 19b-Idem, Serra do Navio

Figura 19c-Idem, Buritirama e Serra do Navio

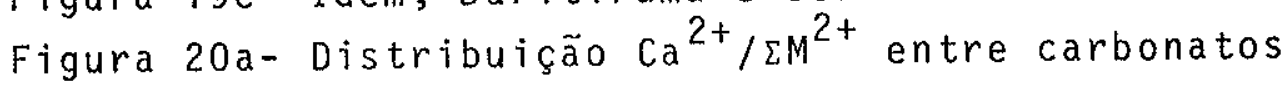
e rodonitas coexistentes. Buritirama.

Figura 20b- Idem, Serra do Navio

Figura 20c-Idem, Buritirama e Serra do Navio

Figura $21 a-$ Distribuição $\mathrm{Ca}^{2+} / \Sigma \mathrm{M}^{2+}$ entre carbonatos e piroxmangitas coexistentes. Buritirama

Figura 21b- Idem, Serra do Navio

Figura 21c-Idem, Buritirama e Serra do Navio

Figura $22 a-$ Distribuição $C a^{2+} / \Sigma M^{2+}$ entre carbonatos e anfibölios manganesifferos coexistentes. Buritirama

Figura 22b-Idem, Serra do Navio

Figura 22c-Idem, Buritirama e Serra do Navio

Figura $23 a-D i s t r i b u i c ̧ a ̃ o ~ C a^{2+}+M n^{2+} / \Sigma M^{2+}$ entre carbona tos e tefroitas coexistentes. Buritirama

Figura 23b-Idem, Serra do Navio

Figura 23c-Idem, Buritirama e Serra do Navio

Figura 24 - Distribuição $\mathrm{Ca}^{2+} / \Sigma \mathrm{M}^{2+}$ entre carbonatos e os piroxenöides de Serra do Navio

Figura 25 - Resultados experimentais de sintese atra vês da reação $(\mathrm{Mn}, \mathrm{Ca}) \mathrm{CO}_{3}+\mathrm{SiO}_{2}=$ $(\mathrm{Mn}, \mathrm{Ca}) \mathrm{SiO}_{3}+\mathrm{CO}_{2}$ ä $\mathrm{P}$ total $=2 \mathrm{~Kb}$ e $\mathrm{X}_{\mathrm{CO}_{2}}$ variando entre 0,3 e 0,6 
$-v i j i-$

Figura 26 - Distribuição $\mathrm{Ca}^{2+} / \Sigma \mathrm{M}^{2+}$ entre carbonatos e os piroxenöides de Buritirama

Figura 27 - Distribuição $C a^{2+} / \Sigma M^{2+}$ entre carbonatos e rodonitas, piroxmangitas, espessartitas e anfibolios manganesiferos de Bur $\underline{i}$ tirama e Serra do Navio

Figura 28 - Soluções sölidas no sistema $\mathrm{CaCO}_{3}$ -

- $\mathrm{MgCO}_{3}-\mathrm{MnCO}_{3}$ à pressão total de $10 \mathrm{~Kb}$ (a) $500^{\circ} \mathrm{C}$ (b) $600^{\circ} \mathrm{C}$ 
RESUMO

Amostras frescas de furos de sonda das jazidas de man ganēs de Serra do Navio, Amapā, e de Buritirama, Parā foram estü dadas

Em Buritirama ocorrem os seguintes tipos de protomine rios de manganês: märmores calcossilicāticos, piroxmangita märmo res, braunita märmores, tefroita-alabandita märmores e xistos calcossilicăticos manganesiferos. As rochas encaixantes são constitü̈das por märmores, rochas calcossilicāticas, xistos e quartzitos dobrados, de atitude geral: direção N60W e mergulho 20-30 NE. Este pacote de rochas metassedimentares faz parte do Grupo Grão Parā que è sobrejacente às rochas do complexo xin gü.

Os protominērios de manganēs de Buritirama caracterizam-se pela sua natureza sîlicomcarbonätica, ausēncia de grafita e presença de braunita e hausmanita, alëm de carbonatos da sērie Mn-calcita - Mn-kutnahorita, piroxenöides manganesifferos (pirox mangita e rodonita), olivina (tefroita), espessartita, clinoanfi bölios manganesiferos, manganoflogopita (manganofilita) e aces sörios (alabandita, esfalerita, espinēlio manganesifero e piro fanita).

Soluções sōlidas dos carbonatos indicam temperaturas superiores a $550^{\circ} \mathrm{C}$ para o pico do metamorfismo sofrido pelo pro tominērio. A paragēnese: braunita + hausmanita + carbonato man ganesîfero indica temperatura semelhante e $\log \mathrm{f}_{0_{2}} \cong-8$.

As associações das encaixantes calcossilicatadas (cal cita-dolomita-quartzo-diopsidio-tremolita) e das metapeliticas indicam temperaturas, entre 500 e $600^{\circ} \mathrm{C}$. Estudo de inclusões fluidas em grãos de quartzo, somados aos dados acima, indicam que em Buritirama, o pico do metamorfismo atingiu as seguintes condi ções: $T=550 \pm 50^{\circ} \mathrm{C} ; P=3.000 \pm 300 \mathrm{~atm} ; \log \mathrm{f}_{0_{2}} \cong-8 ; \mathrm{e}, \mathrm{X}_{\mathrm{CO}}$ 
maior que 0,8 .

Estas condições devem ter ocorrido durante metamorfis mo regional progressivo no ciclo orogenētico Transamazônico. Da tações $\mathrm{K} / \mathrm{Ar}$ e Rb/Sr dessas rochas fornecem idades concordantes de $1.960 \mathrm{~m} . \mathrm{a}$. Nenhum outro fenōmeno de monta ocorreu depois des se evento a não ser pequenos cizalhamentos, remobilizações e aco modações.

Em Serra do Navio ocorrem protominērios do tipo mārmo re manganesifero, em forma de lentes envolvidas por estratos de protominério sīlico-carbonätico, encaixados em quartzo-biotita-granada xistos, xistos grafitosos e quartzitos.

Essa sequência metassedimentar sobrepõe-se a rochas do Complexo Guianense. Localmente considerada como Grupo Serra do Navio da Sërie Amapä, este pacote modernamente pertence ao Grupo Vila Nova, de idade Rb/Sr $2.090 \mathrm{~m} . \mathrm{a}$. (ectinitos) e K/Ar 1.800$-1.700 \mathrm{~m} . \mathrm{a}$.

o protominērio carbonātico de Serra do Navio é carac terizado pela associação Ca-kutnahorita - Ca-rodocrosita, olivi na (tefroita), piroxenōides e espessartita, tendo grafita como acessörio constante. Outros minerais menos comuns são: mangano flogopita, clinopiroxēnios manganesîferos - anfibölios mangane siferos, pirofanita e sulfetos.

o protominērio sîlico-carbonático contēm a mesma asso ciação porēm com maior quantidade de granada e piroxenöides em detrimento de olivina e carbonato.

A associação grafita-piroxenöide-olivina-carbonato man ganesifero estabelece para o protominērio temperaturas de $600^{\circ} \mathrm{C}$ e fugacidade de oxigênio $\log f_{0_{2}} \cong-20$, supondo pressões da or dem de $2.000 \mathrm{~atm}$.

As paragēneses das rochas calcossilicāticas indicam ele vada fração molar de $\mathrm{CO}_{2}$ e temperatura da ordem de $620^{\circ} \mathrm{C}$ a $4 \mathrm{~Kb}$, ou temperaturas maiores a pressões mais elevadas (calcita-tremolita-diopsidio-quartzo). 
As rochas xistosas, metapelitticas mais ou menos silicä ticas são mais favorăveis à observação das condições reinantes no metamorfismo sofrido pelas rochas da região. 0 climax do meta morfismo deve ter sido atingido a temperaturas da ordem de $700 \pm$ $40^{\circ} \mathrm{C}$ e pressões da ordem de $5,5 \pm 1 \mathrm{~kb}$ (sillimanita-cordierita -quartzo-granada; muscovita-quartzo-sillimanita-ortoclásio; es taurolita-muscovita-quartzo-sil1imanita-biotita).

Efeitos de metamorfismo de grau mais baixo, tais como a passagem de sillimanita em biotita e andalusita, transformação de sillimanita e ortocläsio para andalusita e microciñnio ou pa ra muscovita e quartzo, etc, são abundantes nas rochas pelîticas. Este metamorfismo de grau mëdio tem seus reflexos tambëm nos pro tominërios, märmores e.rochas calcossilicäticas.

0 primeiro metamorfismo do tipo regional progressivo atingiu temperaturas suficientes para a fusão de rochas de compo sições favoräveis, atribuindo-se aos chamados granitos sintec tōnicos de Serra do Navio, uma origem anatēctica. Apōs um res friamento houve um segundo metamorfismo de grau mēdio (fācies anfibolito), provavelmente responsāvel pelas datações $\mathrm{K} / \mathrm{Ar}$ des ses metassedimentos.

objetivando a comparação das condições de metamorfismo de Serra do Navio e de Buritirama, confeccionaram-se diagramas de porcentagem molar e diagramas de partição de elementos (em peso por cento dos cātions) entre fases coexistentes, com dados de microssonda eletrōnica dos minerais dos respectivos protomine rios manganesîferos. A interpretação desses diagramas eviden ciou condições de equitibrio e diferenças no grau de metamorfi mo das duas äreas.

Descontinuidades nos "trends" de composição dos carbo natos de Buritirama confirmam dados de miscibilidade dos mine rais do sistema $\mathrm{MnCO}_{3}-\mathrm{MgCO}_{3}-\mathrm{CaCO}_{3}$, indicando nessa ocorrên cia, condições tërmicas mais baixas daquelas que prevaleceram ém 
Serra do Navio.

A natureza dos piroxenōides manganesiferos mereceu atenção especial. Estrutura do tipo piroxmangita existe ate um teor limite de Ca0, passando para estrutura do tipo rodonita com o aumento desse teor. 0 conteūdo em cao das piroxmangitas è menor em Serra do Navio e maior em Buritirama, colaborando com da dos experimentais que sugerem ser esse limite dependente da tem peratura. Mais uma vez confirmam-se condições metamórficas mais drästicas na primeira ärea. 
CAPITULO I

INTRODUÇAO

0 Brasil è um dos maiores produtores mundiais de manga nês e a maioria das jazidas em exploração sistemätica è consti tuĩda de minērios formados por enriquecimento supērgeno de ro chas mãe, de natureza metassedimentar, carbonäticas com quanti dades variäveis de silicatos que podem ser genericamente denomi nadas de Queluzitos.

Entre as jazidas com protominërios queluziticos podem ser destacadas as de Buritirama e Sereno no Parä; as de Serrá do Navio, Amapä; as de Lafaiete, Saūde e Säo João del Rey em Minas Gerais.

A potencialidade dessas jazidas de enriquecimento su përgeno, alëm de outros fatores, estä intimamente relacionadacom a natureza carbonătica dos protominērios.

Värios trabalhos sobre a mineralogia e origem secundā ria desses minērios são encontrados na literatura (LEINZ, i948; PARK, 1956; NAGELL, 1962; CASTR0, 1960; VALARELLI, 1966, 1967 , 1975; SCARPELLI, 1973; ANDERSON et al., 1974; MELFI et al.;1973; BITTENCOURT, 1973; DORR et al., 1958). Entretanto quando se re ferem ao protominērio, poucos são os autores (SCARPELLI, 1963, 1968; da SILVA et al., 1961; BELLO et al., 1976; COUTINHO et al., 1976; RIBEIRO FILHO, 1968; EBERT, 1963) que tratam das condições metamōrficas a que foram submetidos os antigos sedimentos. Em alguns trabalhos, a natureza silicātica, pelïtica, carbonätica ou química è correlacionävel a antigos ambientes de sedimentação (SCARPELLI, 1973 e EBERT, 1963).

os melhores estudos sobre o metamorfismo dessas rochas dão maior ēnfase aos aspectos estruturais e texturais e ao cadas tramento dos minerais identificados. Em alguns casos, o inven 
tärio mineralögico das jazidas possui nomes dos vārios minerais, sem levar em conta as associações em equilíbrio.

o objetivo principal do presente trabalho $\bar{e}$ de contri buir para o conhecimento das condições metamörficas a que foram submetidos os protominerios carbonäticos e sijlico-carbonäticos de Buritirama e de Serra do Navio.

A escolha de Buritirama foi ditada por vārios fatores:

1) trata-se de jazida cujo estudo preliminar (ANDERSON et az., 1974) demonstrou ter protominërio constituido por carbo natos, silicatos e öxidos de manganēs. As considerações genëti cas sobre Buritirama poderiam servir de base para estudos seme lhantes das jazidas de Sereno, Urandi e Maraū, respeitando-se as respectivas particularidades. Alëm disso as encaixantes carbonä ticas, calcossilicăticas e metapeliticas seriam favoráveis a um estudo paragenētico.

2) 0 estudo do metamorfismo do protominërio e das ro chas encaixantes de Buritirama poderiam contribuir para o estudo do Grupo Grão parā que adquire, no momento, grande importāncia devido ao desenvolvimento das pesquisas minerais na região.

3) A jazida de Buritirama possui reservas mëdias : em comparação com outras jazidas, mas seu melhor conhecimento e aproveitamento econômico ajudaria a viabilidade da implantação do complexo industrial da região (Marabā - Carajās - Itaqui).

4) 0 trabalho de ANDERSON et al. (1974) sobre Buritira ma, e os estudos regionais da ārea da serra dos carajäs (TOLBERT et al., 1971, 1973 e BEISEGEL et al., 1973) e do Projeto RADAM (LIMA et al., 1974), representavam um suporte adequado para o es tudo proposto.

5) Havia disponibilidade de testemunhos de sondagem.

Escolheu-se Serra do Navio pelos seguintes motivos:

1) trata-se de jazida cujo protominērio ē constituĩdo por carbonatos, silicatos, grafita e sulfetos. A semelhança da 
jazida de Serra do Navio com as de Minas Gerais (Lafaiete, Saūde e São João del Rey) ē flagrante, justificando uma previsão de que a metodologia de estudo e algumas considerações gerais pudes sem ser aproveitadas no estudo destas $\vec{u} 1 t i m a s$.

2) 0 estudo do metamorfismo do protominērio de Serra do Navio e das rochas encaixantes (märmores, rochas calcossilicäti. cas, metapelitos xistosos e rochas quartzo feldspáticas) contri buiria para o conhecimento dos metassedimentos, que constituem o cinturão metamörfico, sobrejacentes às rochas do complexo Guia nense, localmente denominado de Grupo Serra do Navio da Sërie Amapä (NAGELL, 1962), hoje denominado Grupo Vila Nova (LIMA et al., 1974).

3) A jazida de Serra do Navio ê, no Brasil, uma das mais importantes do ponto de vista de reservas. Seu protomine rio, conforme trabalhos anteriores (da SILVA et al., 1961), deve rä ser incorporado às reservas do minērio, da mesma forma que acontece com o protominërio de Lafaiete que estä sendo explorado economicamente.

4) Do ponto de vista prätico, contava-se com muitas in formações geolögicas, tectōnicas, petrogräficas e mineralōgicas da jazida, alēm de se dispor, de um grande acervo de testemunhos de sondagem.

Trabalhos geocronolögicos colocam as duas jazidas estu dadas dentro do mesmo cinturão mövel denominado Maroni-Itacaiu nas, dentro do ciclo orogenëtico tranzamazōnico de idades abso lutas Rb/Sr entre 1.800 e $2.200 \mathrm{~m} . \mathrm{a}$. (GOMES et al., 1975; MONTAL VAO, 1976; CORDANI, 1974; CORDANI et al., 1977; HURLEY et al., 1967). Seria interessante o estudo metamörfico dessas duas äreas e a sua correlação com os eventos tectōnicos evidenciados pelos dados geocronológicos.

Para atingir os objetivos propostos foram efetuados estudos mineralögicos, petrogräficos, paragenēticos, químicos e de inclusões fluidas. 


\section{CAPITULO II}

\section{MATERIAIS E METODOS}

As amostras estudadas neste trabalho são constituidas por testemunhos de furos de sonda coletados nos arquivos das ja zidas.

Baseando-se na descrição do perfil dos furos de sonda e na observação dos arquivos, coletaram-se, a cada intervalo amos tras de aspecto macroscōpico característico (mineralogia e textu ra).

De Buritirama foram amostrados sistematicamente os tes temunhos dos furos nümeros 10,22 e 14 da Mina B-5, contando-se tambëm com värias amostras esparsas de outros furos.

De Serra do Navio foram amostrados os testemunhos dos furos 74, 76 e 96 da Mina Faria, F-12; nümeros 32, 37 e 40 da Mi na Chumbo, C-2; 12, 25 e 50 da Mina Antunes, A-12; e dos furos T-12-12 e T-6-59 da Mina Therezina.

Foram confeccionadas 86 läminas delgadas dessas amos tras seguindo-se sua descrição petrogräfica e mineralögica.

Posteriormente, foram realizados estudos öpticos, mais acurados, tais como: determinação dos indices de refração das granadas e de $n_{w}$ dos carbonatos pelo mëtodo de imersão; determi nação do ãngulo $2 \mathrm{~V}$ entre os eixos ōpticos, āngulo entre as cli vagens e ängulo entre direções cristalogräficas e direções ōpti cas dos piroxēnios, piroxenöides e olivinas, atravēs da platina Universal de Federov, a três eixos.

A difratometria de raios $X$ foi utilizada rotineiramen te, obtendo-se numerosos difratogramas comuns de agregados e de minerais individuais, coletados de amostra de mão por meio de broca à diamante, com controle optico de lupa. Foram utilizados os aparelhos de difratometria "Philips Norelco 2 KVA" e "Geol 
IKVA". Filmes especiais em cāmaras "Debye-Scherer" e de "Guinier" possibilitaram a obtenção de dados cristalogräficos ne cessārios à correlação composição-propriedades dos diversos mine rais. Para os carbonatos, foram efetuadas medidas de $d_{10.4^{-d}} 10.2$ e medidas de $\Delta d_{104}$ com padrão interno de calcita (GOLDSMITH \& GRAF, 1957). Para as granadas empregou-se mëtodo analitico para determinação de $a_{0}$ a partir de diagramas de pö.

Após cuidadosos estudos ópticos e roentgenogräficos es tabeleceram-se as principais paragēneses das quais foram selecio nadas amostras para o estudo da composição quimica dos minerais atravës da microssonda eletrōnica. As associações interessantes foram fotografadas indicando-se na foto e na secção de microsson da os minerais em equilibrio, os quais seriam posteriormente ana 1isados. Foram examinados os seguintes minerais: granadas, car bonatos, olivinas, piroxenóides e em alguns casos tambēm clino piroxênios, anfibölios e micas manganesiferas, com respeito à $\mathrm{Mg}$, $\mathrm{Fe}, \mathrm{Mn}, \mathrm{Ca}, \mathrm{SiO}_{2}, \mathrm{Al}_{2} \mathrm{O}_{3}$ e outros elementos de amostras dos proto minérios de Serra do Navio e de Buritirama.

A partir dos dados de microssonda eletrónica obtiveram- se gräficos de partição de elementos entre as fases coexisten tes na mesma lämina. Para isso, converteu-se a porcentagem em peso dos öxidos em porcentagem em peso dos cätions.

Utilizou-se a partição $\mathrm{Ca}^{2+} / \mathrm{Ca}^{2+}+\mathrm{Mn}^{2+}+\mathrm{Fe}^{2+}+\mathrm{Mg}^{2+}$ entre rodonita, piroxmangita, espessartita, clinoanfibolios carbonatos coexistentes, assim como a relação $\mathrm{Mn}^{2+}+\mathrm{Ca}^{2+} / \Sigma$ cätions bivalentes entre tefroitas e carbonatos.

os dados obtidos foram submetidos a câlculos estatisti cos em computador.

Para as considerações referentes ao tipo de metamorfís mo foram usados todos os dados de observação disponíveis e os dados de estudos termodinâmicos das reações concernentes às para gêneses encontradas. Constantes de equilibrio para fases impu 
ras, atividades dos componentes, pressão parcial de oxigênio,pre sença ou não de grafita ou öxidos de manganês, relação $x_{\mathrm{CO}_{2}}{ }^{-}$ $X_{H_{2}} \mathrm{O}$ na fase fluida, temperatura e pressão total foram levadas em ${ }^{2}$ consideração.

Estudos de inclusões fluidas em grãos de quartzo preser vados entre diferentes minerais de manganēs, utilizando platina aquecedora "Chaix-Meca" enriqueceram os dados de densidade cri tica do $\mathrm{CO}_{2}$ e as correlações entre temperatura e pressão nas pa ragēneses de Buritirama. 
CAPITULO III

JAZIDA DE MANGANES DE BURITIRAMA

III - I - ASPECTOS GEOLÖGICOS DE BURTTIRAMA

Os depösitos de manganēs de Serra do Sereno, Serra de Buritirama e Azul, localizam-se na parte centro leste do Estado do Parā, numa região drenada pelo rio Itacaiunas, afluente ocidental do rio Tocantins, entre as coordenadas geogräficas $5^{\circ} 30^{\prime}$ e $6^{\circ} 06^{\prime} \mathrm{S}$ e $49^{\circ} 32^{\prime}$ e $50^{\circ} 18^{\prime} \mathrm{W}$ Gr. (ANDERSON, DYER \& TORRES, 1974) (Figura 1).

A região è caracterizada por planīcies recobertas por florestas tropicais, numa altitude mëdia da ordem de $250 \mathrm{~m} .0 \mathrm{cas} i \underline{0}$ nalmente aparecem cristas alongadas com relevo de cerca de 100 a $200 \mathrm{~m}$, onde se destaca a região serrana que constitui a serra dos Carajäs cujo desnīvel è de 350 a $450 \mathrm{~m}$.

os terrenos Prë-Cambrianos da Bacia do rio Itacaiunas fazem parte do chamado Craton do Guaporë, unidade cratonizada no ciclo Transamazōnico. Esse ciclo è bem caracterizado na Serra dos carajäs, onde ocorrem rochas de ambiente possivelmente geossinclinal, representadas pelo Complexo Xingu e Grupo Grão Parā.

As rochas mais antigas da região, representadas por gnaisses e anfibolitos polimetamörficos, pertencem ao complexo Xingu. (Figura 1).

0 Grupo Grão Parä é formado na região da Serra dos Carajās, por uma sequência metassedimentar, sobreposta discordantemente ao embasamento mais antigo. A litologia é representada por xistos, quartzitos e duas sequéncias metavulcānicas bāsicas que contēm a formaçăo ferrưfera, denominadas de "sequência paleovul- 


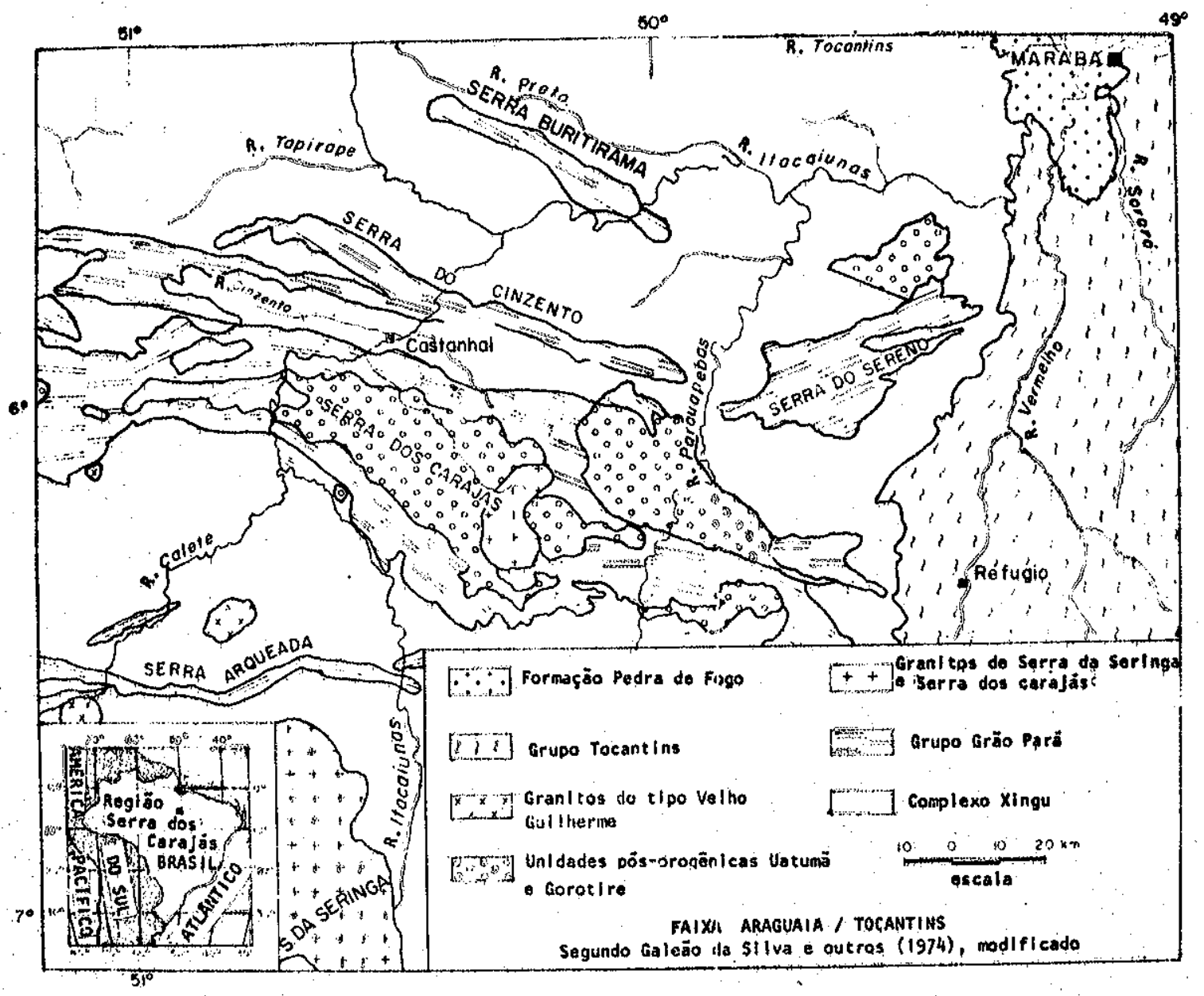

Figura 1 - Mapa geolögico da região de Serra dos Carajás.Lo calização e geologia regional da ärea, incluindo a região de Serra de Buritirama. Segundo GALEÃo DA Silva et al.,1974. Modificado: como em GOMES et $a$ h., 1975 . 
cânica superior e inferior" e constituídas por metabasitos espe1 itizados.

TOLBERT et al. (1971) e GOMES et al. (1975) obtiveram pa ra as rochas metavulcānicas afetadas pelo ciclo orogēnico transa mazōnico, idades K/Ar em torno de 2000 m.a.-Prë-Cambriano Mëdio.

Sobrepondo-se discordantemente às unidades do Grupo Grão Parä, existe uma sequência sedimentar molassoide com espessura superior a $1.500 \mathrm{~m}$, constituída por rochas areniticas e conglomeräticas alēm de siltitos, folhelhos e calcärios alternados, que pertence ao Grupo Uatumã. A parte superior dessa sequencia, designada por TOLBERT et al. (1971) por Membro Azul, contém os pe 1 itos e calcärios manganesîferos primärios que originaram o depö sito do Azul. Essa sequēncia contēm depósitos de manganēs semelhantes aos da Sërie Francevilliana, do Gabão. (VALARELLI, J.v. 1977).

Na região da Serra de Buritirama as rochas do embasamento (Complexo Xingu) são representadas por biotita gnaisses, hornblenda gnaisses e anfibolitos.

A sequēncia metassedimentar que constitui o Grupo Grão Pará, inicia-se, nessa região, por um quartzito basal seguido por um pacote de xistos de litologia diversificada que contēm os horizontes de protominérios manganesiferos sîtico-carbonäticos: e : camadas de quartzito. Esses horizontes foram oxidados e sofreram enriquecimento supērgeno originando os depōsitos de manganēs de Buritirama.

A Serra de Buritirama se estende rumo NW, a partir do rio Itacaiunas, por uma distāncia de $47 \mathrm{~km}$. Nas proximidades des se rio, a Serra se divide em dois ramos, chamados respectivamente de serras $A$ e $B$, que são duas abas de um anticlinal. (Figura 2).

A Serra $B$ que apresenta um relevo de 150 a $200 m$ de altura, sustentado pelo quartzito basal, parcialmente sobreposto pelo minërio de manganēs supërgeno, possui as maiores ocorrēn cias de manganēs. 


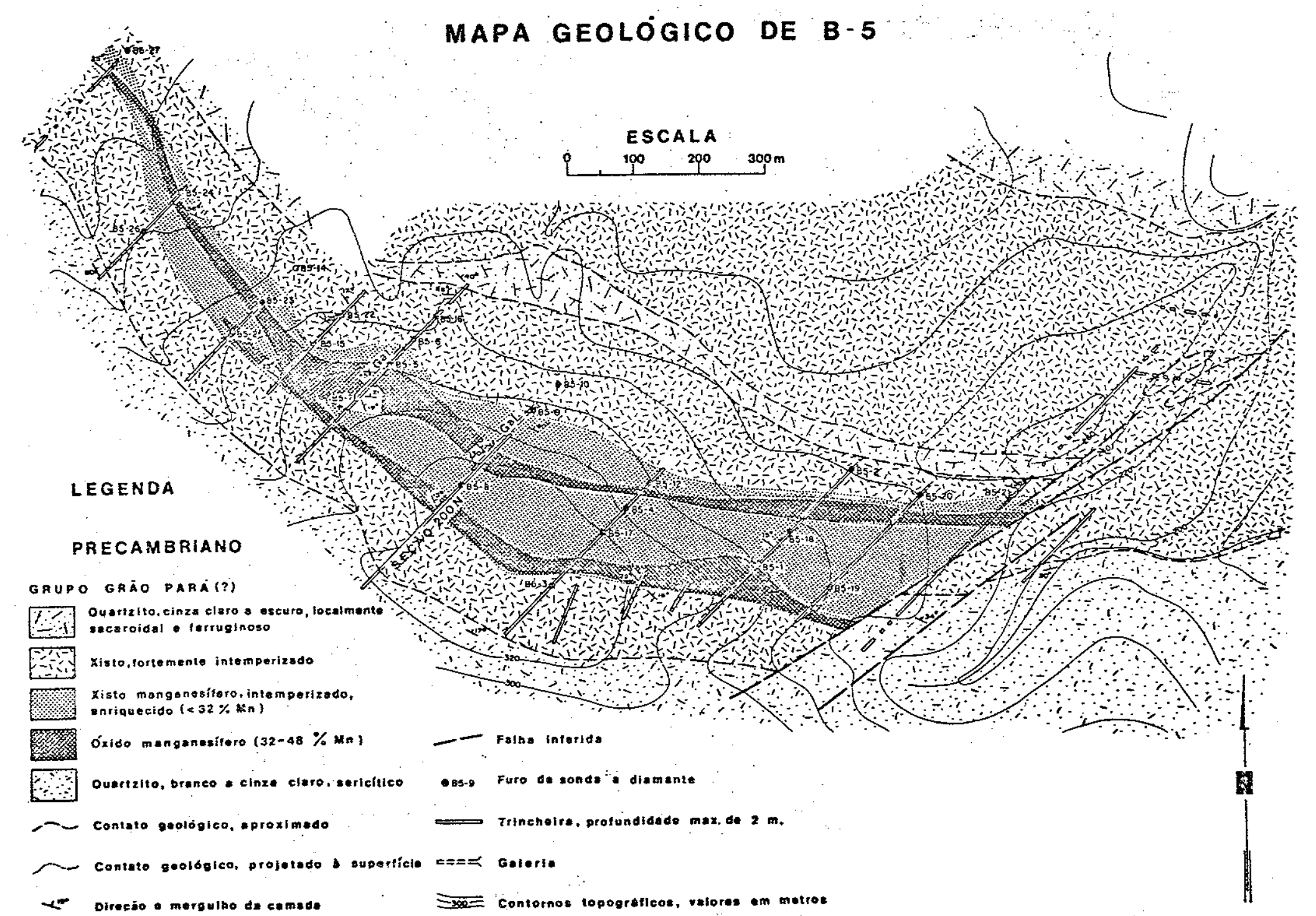

Figura 2 - Mapa geológico da Serra de Buritirama - segundo ANDERSON, DYER \& TORRES 1974. 
A SE do rio Itacaiunas desaparece o quartzito responsā vel pelo relevo de Buritirama devido talvez a mudança faciológica, reaparecendo porēm cerca de $65 \mathrm{~km}$ depois de maneira predominante, na Serra do Sereno. Essa Serra se estende na direção ENE, possuindo cerca de $45 \mathrm{~km}$ de comprimento, at $\overline{\mathrm{e}} 4 \mathrm{~km}$ de largura e um relevo mäximo da ordem de $200 \mathrm{~m}$.

As mesmas feições litolögicas e estruturais de Buritirama são encontradas na Serra do Sereno, sendo as ocorrências de manganês das duas serras consideradas do mesmo tipo genētico (ANDERSON et al., 1974).

As ocorrências de manqanēs dos dois ramos constituintes da Serra de Buritirama ( $A$ e B) sao, na major parte, corpos de formas lenticulares com extensöes mëdias de $180 \mathrm{~m}$, sendo exceçöes as ocorréncias B4 e $B 5 \mathrm{com}$ extensões sensivelmente maiores. 0 corpo B4 apresenta trēs āreas mineralizadas, totalizando $3,3 \mathrm{~km}$ de com primento. Na parte mediana da Serra B estä localizada a maior ocorrēncia conhecida, corpo B5, Figura 3 , que tem $1.400 \mathrm{~m}$ de comprimento, 35 a $240 m$ de largura (em planta) e 5 a $30 \mathrm{~m}$ de espessura. Esse corpo desaparece a NW por acunhamento e a SE seu desapa recimento parece estar relacionado a falhamento(ANDERSON et al., 1974). Na Figura 4 è mostrada uma seçäo transversal desse corpo. e sua forma irregular que segundo esses autores é devida à perda de volume e conseqliente afundamento causados por processos de oxidação e de enriquecimento supërgeno. Essa secção mostra protominērios de manganēs intemperizados, intercalados com micaxistos e quartzitos, todos com a mesma atitude geral N60W, 20-30 $\mathrm{O}$ " :

Material manganesifero duro e maciço, com teores de 46 a $47 \%$ de Mn estā limitado a uma zona superficial. Esse material gradua rapidamente para baixo a um material mais fino, friāvel, formado por öxidos de manganēs e minerais de argilá,que constitui o total do minërio bruto $(32-46 \%$ de $M n)$ atë o nível mais baixo de intemperismo. A zona de ocorrência do protominērio estä situada abaixo desse nível, cerca de $60 \mathrm{~m}$ de profundidade.

Zonas de xistos intemperizados, impregnados com öxidos 


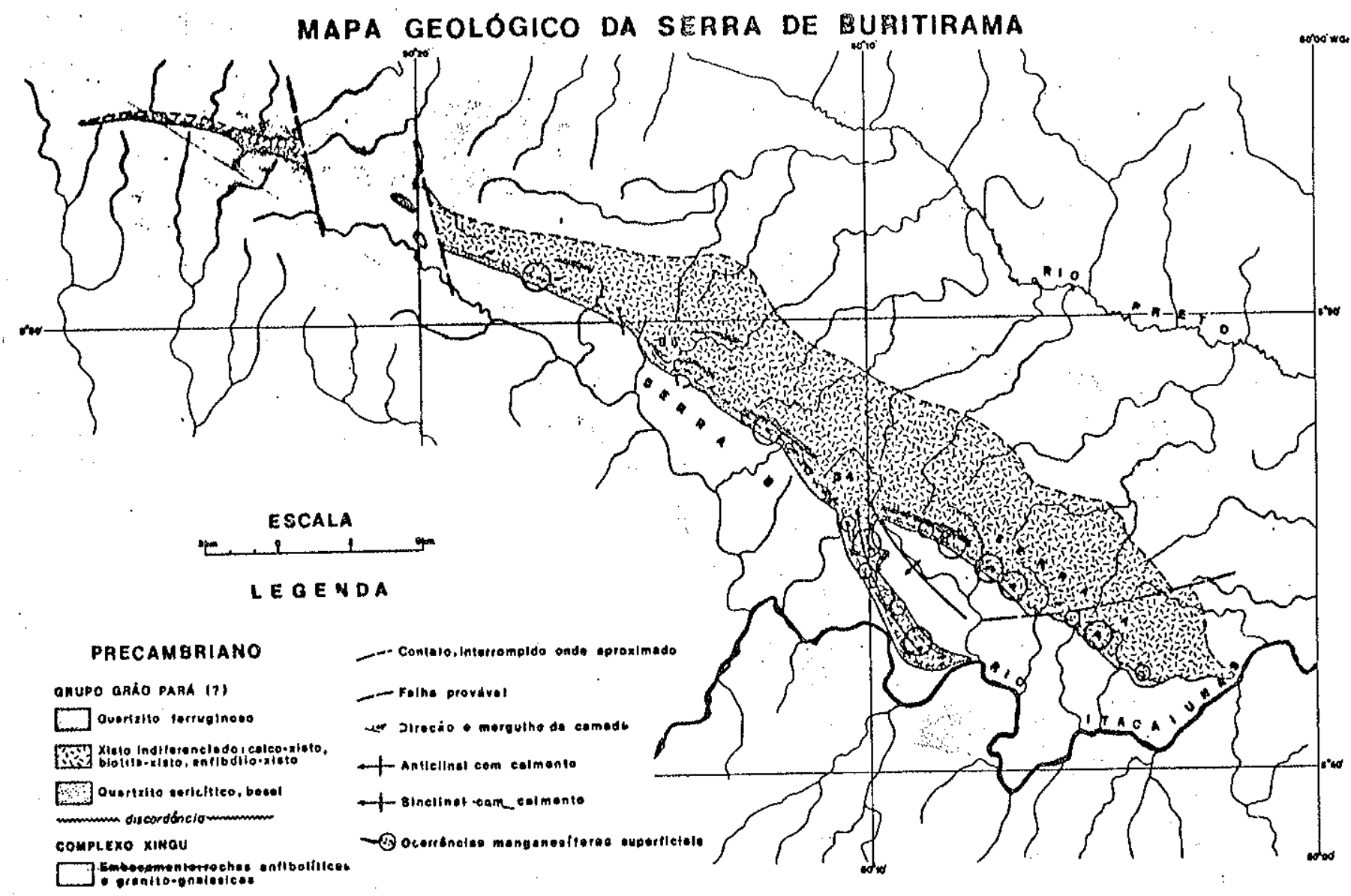

Figura 3 - Mapa geológico do corpo de minério B-5. Segundo ANDERSON, DYER \& TORRES, 1974. 
e ōxidos hidratados de manganès, envolvem as concentrações lenti culares de minērio ou são às vezes intercaladas com elas.

Minerais autigēnicos do minërio supērgeno são: criptomelana, litioforita, nsutita e buserita (ou $\mathrm{MnO}_{2}$ amorfo). Em protominērios intemperizados e em lama de sondagem do minērio aparecem braunita e hausmanita como minerais reliquiares.os prin cipais minerais de ganga são: mica, clorita, minerais de argila, gibbsita, goethita e espessartita intemperizada. (ANDERSON et a , 1974):

III - 2 - ESTUDO DOS PROTOMINERIOS E ENCAIXANTES DE BURITIRAMA

\section{$111-2-1$ - GENERALIDADES}

0 depösito de manganēs de Buritirama è composto por 9 afloramentos situados na Serra $A$ e por 30 afloramentos na. Serra B, os maiores sendo B4 e $B 5$.

A partir do estudo mineralōgico e petrográfico de amos tras do corpo B5 (furos de sonda, 2, 5, 6, 9, 10, 12, 14, 15, 16 e 22), Figura 3, obteve-se a maioria das informações a respeito da natureza e tipos de protominërios e das rochas encaixantes.

De uma maneira geral o protominério è constituído de märmores e xistos calcossilicatados manganesiferos, e estä encaj xado em calco-mica xistos com intercalações de camadas de märmo re.

$\mathrm{Na}$ Figura 4, seção geolōgica - $200 \mathrm{~N}$ do corpo B5, vêmse protominërios e minërios intercalados nos micaxistos. 0 pacote de xistos contendo os protominērios estä situado abaixo de um quartzito sacaróide e acima de quartzito sericitico com atitude geral N60W e mergulhos de $20 \cdot 30^{\circ} \mathrm{NE}$.

A alteração supērgena atinge em mëdia $60 \mathrm{~m}$ de profundi 


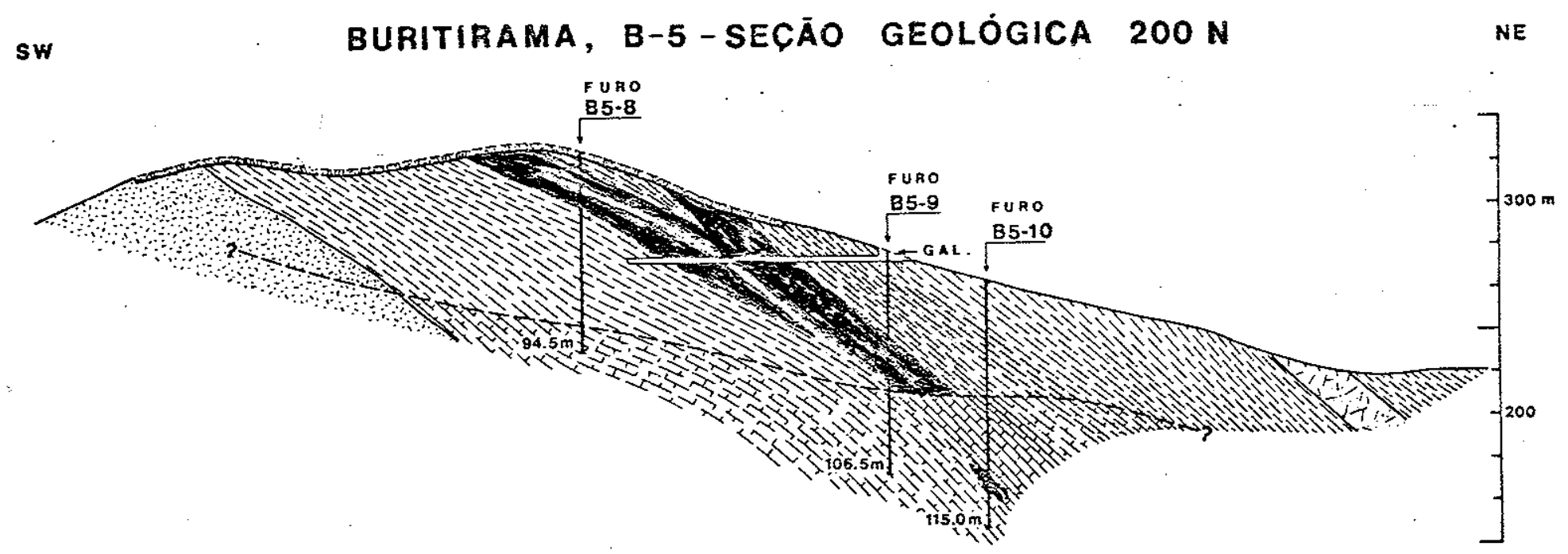

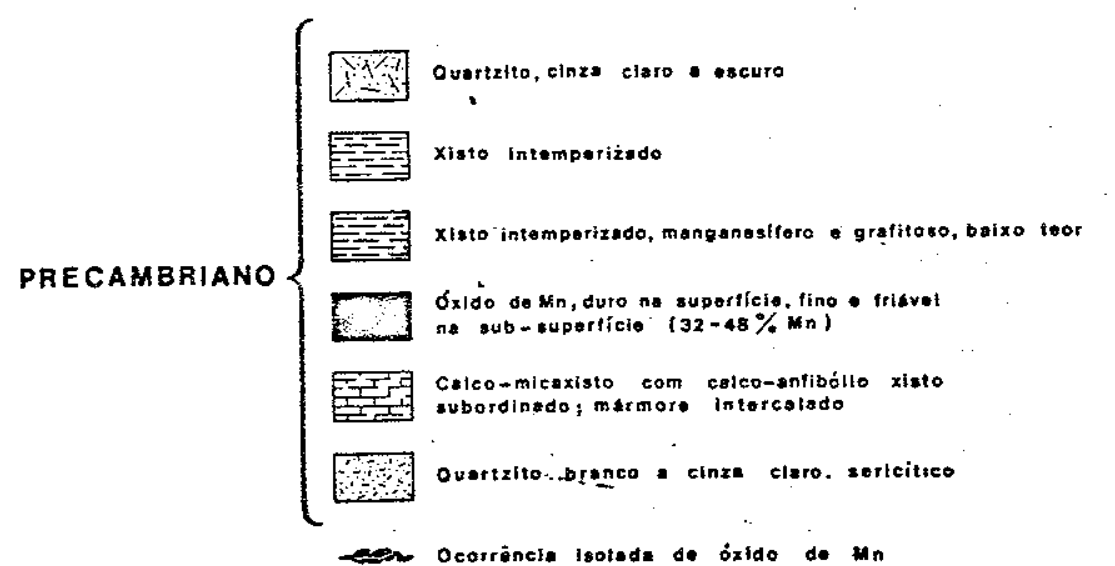

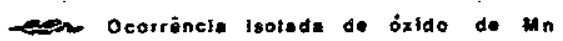

- Portil de intemperismó

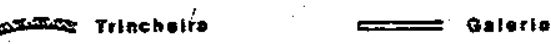

ESCALA

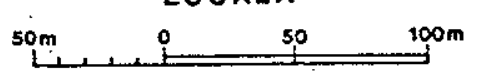

FIG. 4

Figura 4 - Seção geológica $200 \mathrm{~N}$ do corpo de minéxio B-5 - Segundo ANDERSON, DYER \& TORRES, $1974 \stackrel{\frac{1}{\vec{f}}}{\frac{1}{1}}$ 
dade. 0 protominērio só pode ser estudado baseando-se em furos profundos e de localização favorāvel ou seja, furos que cortem lentes de protominërio abaixo de 60m como B-5-10, B-5-22,B-5-14.

\section{|| $\mid-2-2-$ DESCRIÇÃO DE FUROS DE SONDA}

A Figura 5 mostra os furos verticais $B-5-9$ e B-5-10 do perfil $200 \mathrm{~N}$. Nesse perfil pode-se observar a natureza dos proto minérios e suas relações com as encaixantes na zona de rochas frescas do furo B-5-10 e o caráter supērgeno do minério na zona intemperizada do furo B-5-9. O protominērio de manganēs sobrepõe -se a um calco mica-xisto com intercalações de märmore calcossili cático tendo como capa um calco xisto grafitoso que gradualmente passa para um hedembergita-granada-mica xisto.

$$
\text { III }-2-2-1-\text { Furo B5-10 }
$$

Na parte mais profunda deste furo (99,5-115m) encontra -se um pacote onde intercalam-se faixas de calco-anfibolio-mica xistos e de märmores calcossilicáticos. As primeiras tem coloração cinza, composição e textura variāveis: leitos milimétricos de granulação fina e textura lepidoblástica $(0,2-0,6 \cdot \mathrm{mm})$ formados por clinopiroxēnio, flogopita e calcita (esta ūltima granoblásti ca) e leitos onde predominam clinopiroxênios porfiroblásticos e poiquiloblásticos, parcialmente transformados em agregados de clinoanfibólios (tremolita), dolomita e serpentina e ocasionalmen te epidoto. Os acessōrios desses calco xistos são microclínio, apatita e magnetita. (Fotos 1 e 2 ).

As faixas de märmores possuem textura lepidoblástica e são formadas por carbonatos $(40 \%)$, flogopita orientada (20-30\%) e salita $(20 \%)$, apresentando tambēm microclinio e clinoanfibólio 
FURO B-5-9

Profundidade em $m$.

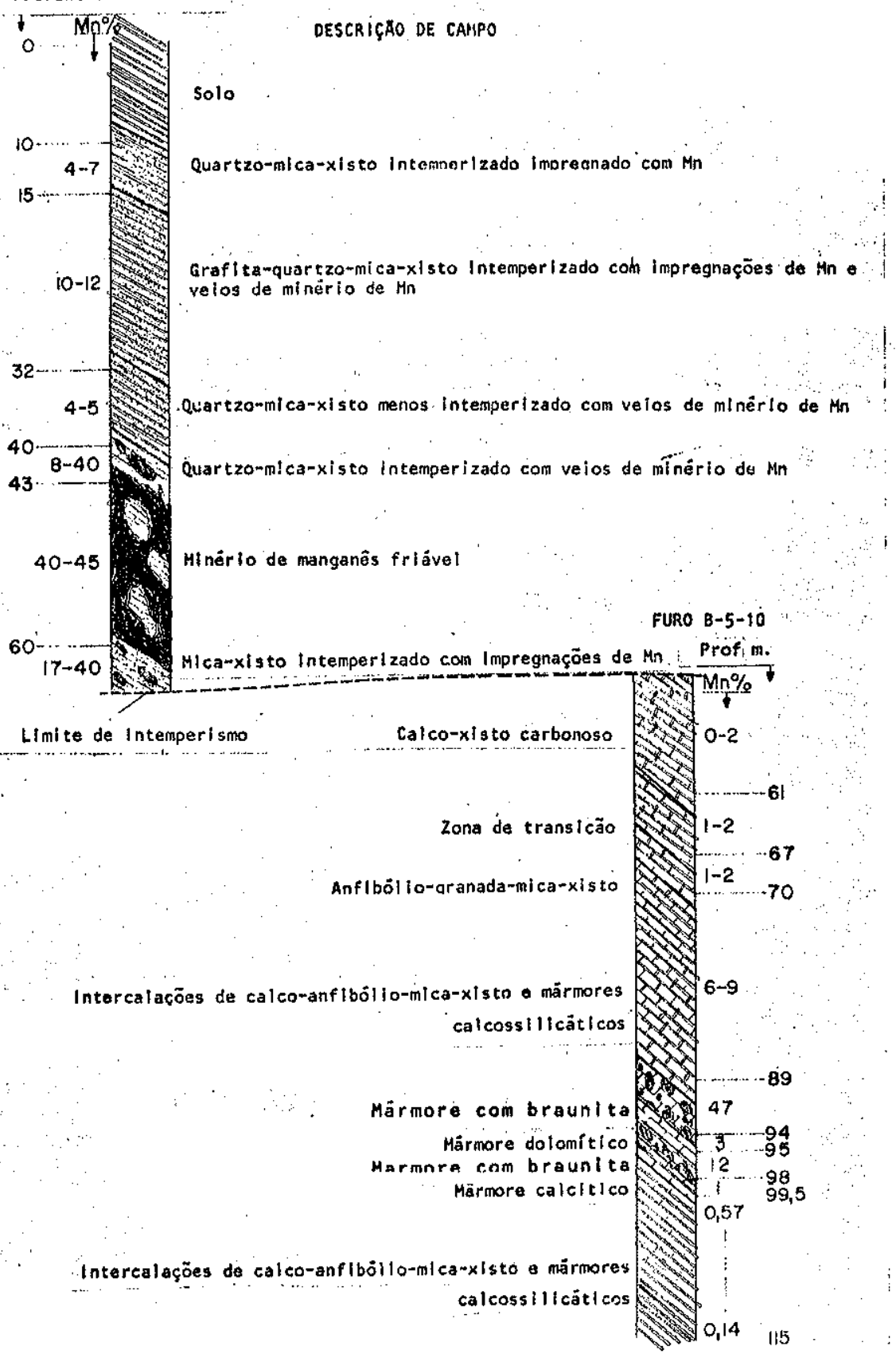

Figura 5-Perfil litológico esquemático da zona intemperizada do furo de sonda B5-9 e da zona de rochas frescas do furo de sonda B5-10. 
em quantidades subordinadas. Os carbonatos, mangano calcita e do lomita, juntamente com salita constituem às vezes leitos mais grosseiros $(0,5-2,0 \mathrm{~mm})$. (Fotos 3 e 4$)$.

Entre os niveis 98 e $99,5 \mathrm{~m}$, encontra-se märmore calc tico com orientação dada por concentrações de flogopita. Como acessörios existem granada e minerais opacos.

Acima dessa sequēncia, entre 98 e $89 \mathrm{~m}$, encontra-se um pacote de märmore contendo manchas, disseminações ou partes maciças (lembrando fragmentos) de minerais metāi icos, constituĩdas essencialmente de braunita com quantidades subordinadas de hausmanita. As partes maciças contēm, em geral, pequenas inclusões de carbonato e flogopita. (Fotos 5 a 9).

Ainda säo encontrados veios silicosos onde é comum a presença de feldspato potássico, barita e apatita, e veios forma dos por carbonato de granulação grosseira com flogopita ou manga nofilita, $\left(2 \mathrm{~V} \cong 40^{\circ}\right)$. Veios submilimetricos de clinoanfibölios e carbonatos cortam as partes opacas. (Foto 10).

Existem algumas zonas de transição entre os opacos e os veios silicäticos que são constitữdas por massa granobiástica de ortociásio englobando quartzo arredondado, albita(pequena quantidade) e também cummingtonita incolor passando a amarelada nas bordas. (Foto 10).

os carbonatos da matriz e dos veios apresentam compos çöes variäveis. Baseando-se em dados ōpticos e roentgenogräficos encontrou-se uma variação nos carbonatos de Mn-kutnahorita, (predominantemente Mg-kutnahorita) ate $\mathrm{Mn}-\mathrm{calci}$, ta $\mathrm{com} 20 \%$ de $\mathrm{MnCO}_{3}$. Dentro deste pacote ocorre uma intercalação mëtrica de märmore dolomitico de textura granoblästica brechóide, constituido essen cialmente de Mn-dolomita e disseminaçães de minerais opacos, cor tado por veios de carbonatos mais manganesiferos posteriores associados a manganofilita. (Amostras: B5-10-94,3m; B5-10-96,80-96,95m).

Segue-se um pacote espesso, entre 89 e $72 \mathrm{~m}$, constituído por intercalações de rochas calcossilicatadas e märmores com teor de manganês de 6 a $9 \%$. 
As rochas calcossilicatadas dessa sequência são orientadas, com textura granoblästica contendo concentrações variáveis de diopsidio, microclinio, flogopita e carbonato conforme os estratos. (Fotos 11 e 12). o microclinio possui inclusões de quartzo. Pode ser encontrado tambēm feldspato alcalino homogéneo. A calcita possui inclusões de granadas de granulação muito fina. (Foto 12). Nessas rochas são ainda encontrados veios constituĩdos por associações de sericita, biotita, carbonato e barita (Amostra B5-10-80,2 m).

As intercalações de märmore possuem uma quantidade de carbonato superior a $45 \%$ com textura granoblästica pavimentosa contendo inclusões de granadas de granulação fina. 0 carbonato estă associado a flogopita.

São tambëm observadas algumas lentes irregulares mais grosseiras (2-3mm) constituîdas por rodonita, diopsídio, granada, flogopita, apatita, barita e opacos (amostra: B5-10-83,3 m). 0 carbonato encontrado é a calcita de uma maneira geral, existin do alguns leitos de kutnahorita.

A seguir, entre os niveis 60 e $70 \mathrm{~m}$, ocorre um pacote constituido por rochas calcossilicatadas inalteradas, ricas em hedembergita, biotita, granada, microclinio e quantidade subordi nada de clinoanfibólio, titanita e turmalina, de textura granoblästica (Fotos 13, 14, 15 e 16), que graduam a rochas de textura lepidoblástica ricas em biotita contendo ainda microclínio e acessörios: turmalina e zoizita (Fotos 17 e 18). Em certos niveis a rocha tem textura granoblästica e $\vec{e}$ constituida predominantemente de diopsidio (67\%) (Foto 31) com calcita e microclinio, tendo titanita como acessōrio comum. Em outros a textura ē lepidoblästica e o diopsídio $\vec{e}$ menos abundante aparecendo muita flogopita, calcita, granada e clinoanfibölio (cummingtonita).Como acessōrios aparecem: opacos, apatita e clorita (amostra: B5-10-62,3 m). 


$$
\text { III }-2-2-2-\text { Furo B5-22 }
$$

0 furo B5-22 entre 50 e $60 \mathrm{~m}$ cortou xistos alterados en riquecidos em öxidos de manganēs que dificultam um estudo micros cópico mais detalhado.

Entre 60 e $70 \mathrm{~m}$ este furo atravessou o protominērio de manganēs que se constitui numa rocha mais ou mènos homogênea, mär more de textura granoblästica com 40 a $80 \%$ de carbonato contendo ainda granada, piroxmangita, Mn-flogopita, (olivina, em alguns casos) e acessōrios: clinopiroxēnio, serpentina, pirofanita e opacos (Amostras: B5-22-64,3m-B5-22-65,8m-B5-22-67, Im) (Fotos $19,20$ e 21$)$.

Em alguns casos a rocha apresenta granulação muito uni forme. Os minerais kutnahorita, piroxmangita e Mn-flogopita tem granulação entre $0,2-0,4 \mathrm{~mm}$, destoando somente as granadas mais finas $(\sim 0,01 \mathrm{~mm})$; em outros, a piroxmangita forma porfiroblastos $(2-10 \mathrm{~mm})$ as vezes serpentinizados, estando associada a olivi na $(0,2-0,4 \mathrm{~mm})$ e kutnahorita $(0,1-0,3 \mathrm{~mm})$ com granada e pirofanita finas $(0,01-0,03 \mathrm{~mm})$. (Amostra: B5-22-65,8m).

Alguns veios de $0,5-1 \mathrm{~mm}$ constituidos de serpentina, sericita e opacos são vistos em certas lâminas.

$$
\text { III }-2-2-3-\text { Furo B5-14 }
$$

0 furo B5-14 atravessou o protominërio entre 65 e $80 \mathrm{~m}$. Trata-se de uma sequência de calcoxistos com intercalações de märmores manganesiferos. Nos niveis 80,8 e $78,8 \mathrm{~m}$ existem olivinas märmores com carbonatos do tipo kutnahorita-rodocrosita que contëm inumeras inclusões de granada fina perfazendo mais de $50 \%$ das läminas.

Trata-se de rochas com textura granoblästica orientada (carbonatos e olivinas $0,2-1 \mathrm{~mm}$ ) com porfiroblastos isorientados 
de olivina $(3-8 \mathrm{~mm})$, contendo inclusões finas de carbonato e granada. Acessōrios comuns são flogopita e piroxmangita. No nível $80,8 \mathrm{~m}$ aparece alabandita disseminada e isolada em cristais de 0,5-2,0mm, ausentando-se mais acima no nivel 78,8m. (Amostras: B5-14-78,8m e B $5-14-80,8 m)$.

Nas sequências superiores de märmores, nível $72 \mathrm{~m}$ a $01 \underline{1}$ vina e os opacos desaparecem dando lugar a märmore de textura gra noblästica orientada, de granulação uniforme $(0,1-0,5 \mathrm{~mm})$ com kut nahorita $(60 \%)$, Mn-flogopita $(25 \%)$, granada (10\%) e piroxmangita $(5 \%)$. (Foto 22 ).

Acima, niveis $69,9 \mathrm{~m}$ e $67,8 \mathrm{~m}$ aparecem märmores de textu ra granoblástica orientada onde a piroxmangita pode constituir atē $35 \%$ dos minerais presentes (kutnahorita, granada, restos de olivina serpentinizada), ocorrendo as vezes como porfiroblastos de $2-7 \mathrm{~mm}$. (Fotos 23,24 e 30 ). Veios de piroxenöide, anfibólio, granada e carbonato, assim como faixas formadas oor serpentina + barita + esfalerita atravessam as 1àminas.(Amostra: B5-14-69,9m).Algu mas vezes, Mn-flogopita predomina sobre piroxenóides (piroxmangi ta) constituindo $30 \%$ da lämina, que apresenta textura granoblāstica pavimentosa com $60 \%$ de carbonato (kutnahorita) possuindo ainda granada e opacos (espinēlio?) como acessórios. (Foto 25).

Existem tambēm algumas intercalações de mārmores dolomiticos, brancos com textura granoblástica, em que o piroxēnio (diopsídio) toma o lugar dos piroxenóides manganesíferos, conten do ainda anfibólio incolor (tremolita) e acessórios.

\section{$111-2-3-$ TIPOS DE PROTOMINERIOS}

Em vista dos dados apresentados acima, os protomine-rios de manganês de Buritirama podem ser considerados numa pri-. meira aproximação como märmores manganesifferos mais ou menos silicáticos intercalados e/ou gradando para calco-xistos manganes feros. 
0 estudo petrogräfico e mineralögico pormenorizado, no entanto, permite a descrição dos seguintes tipos de protominerios, alguns dos quais se distinguem pela originalidade de sua paragènese.

\section{Märmores calcossilicäticos}

São rochas (Fotos 19,20 e 21 ) constituídas principalmente por Mn-clinopiroxénios poiquiloblästicos, carbonatos com composição variando de Mn-calcita a Mn-kutnahorita e flogopita manganesífera. Ainda pode ser encontrado feldspato potässico como maior constituinte em algumas amostras.

Trata-se de rocha com textura granoblástica contendo teor de carbonato superior a $45 \%$, o qual possui inclusões finas de granada.

Em veios, observa-se anfibölio de manganês substituindo os clinopiroxēnios e a rocha apresenta-se ainda cortada por vênulas de clorita.

0 pacote de calcoxistos, com intercalações de märmores calcossilicāticos, contëm teor de manganēs variando entre 6 e $9 \%$ no furo $B 5-10$.

\section{Piroxmangita märmores}

São rochas (Fotos 22,23 e 24 ) constituídas essencialmente de carbonato (kutnahorita) de granulaçäo 0,2 a $0,4 \mathrm{~mm}$ e es pessartita mais fina $(0,01 \mathrm{~mm})$ numa textura em mosäico, com porfi roblastos de piroxmangita de 2 a $10 \mathrm{~mm}$ que apresentam geminação lamelar. Em alguns casos a piroxmangita pode constituir mais que $35 \%$ dos minerais presentes, estando associada a restos de olivinas serpentinizadas. Nessas rochas, o teor de carbonato encontra do $\bar{e}$ de $40 \%$. Os porfiroblastos de piroxmangita apresentam-se tam bém ocasionalmente serpentinizados. Em outros casos, a piroxmangita juntamente com a kutnahorita e Mn-flogopita constituem uma* rocha de granulação uniforme a menos das granadas mais finas.

Em algumas amostras desse protominērio ainda são ob-. 
servados veios de 0,5 - $1 \mathrm{~mm}$, algumas vezes paralelos, de serpentina manganesīfera secundäria. (Foto 22).

\section{Braunita märmores}

Nessas rochas, (Fotos $6,7,8,9,10,26$ e 32), encontramse massas e/ou disseminaçöes de braunita intercrescidas com Mncalcita, manganofilita, feldspato potässico e.clinoanfibölio de manganês. Manchas de concentração de öxidos de manganēs contëm minüsculas inclusões de manganofilita e são separadas por mate rial mais grosseiro constituido por manganofilita e dolomita.

Nesses protominérios ainda são encontrados veios silicäticos onde aparecem rodonita, espessartita e quartzo, alëm de veios submilimêtricos de clinoanfibölios e carbonatos.

\section{Tefroita alabandita märmores}

São Rochas (Fotos 27, 28 e 29), cujo carbonato varia em composição de kutnahorita a rodocrosita, com inclusões de gra nadas finas. A textura $\vec{e}$ granoblästica orientada, ocorrendo a te froita como porfiroblastos com inclusões poiquiliticas finas de carbonato e granada. As dimensões dos porfiroblastos de olivi na são de 2 a $3 \mathrm{~mm}$. Alabandita aparece tanto disseminada fina como sob a forma de cristais de 0,5 a $2,0 \mathrm{~mm}$.

Alēm desses minerais ainda ē encontrada a esfalerita e como acessōrios piroxmangita e hausmanita.

Os sulfetos de manganés foram constatados no nïvel 80,8 do furo de sonda B5-14, estando ausentes em niveis superiores a $78,8 \mathrm{~m}$.

\section{Xistos calcossilicäticos}

São rochas (Fotos 11 e 12 ) orientadas apresentando estratos com porcentagens variadas de Mn-flogopita ou manganofilita,clinopiroxēnio, espessartita e carbonato de manganés.

Ainda podem ocorrer nessas rochas: feldspato potässico, 
pirrotita e barita. Clorita tambëm pode ser encontrada,tendo se formado a partir da manganofilita.

Essas rochas apresentam textura granoblästica e/ou le pidoblāstica dependendo da concentração dos minerais presentes nos estratos distintos.

Algumas amostras ainda apresentam clinoanfibölio inco lor, salita e carbonato em veios com feldspato potässico de baixa triclinicidade. Outras mostram orientação dada por concen trações de flogopita, apresentando tambēm, alēm de carbonatos e granada, oxidos de manganês disseminados.

0 carbonato de textura granoblästica pavimentosa contëm inclusões de granadas finas e estā associado à flogopita isorientada. São encontradas, ainda, lentes irregulares de agre gados mais grosseiros (atē $3 \mathrm{~mm}$ ) contendo essencialmente diopsidio, associado ä granada, flogopita, apatita, barita e opacos.

\section{III - 3 - MINERALOGIA DOS PROTOMINERIOS}

Neste item serão descritas as principais propriedades dos minerais encontrados nos protominērios de manganēs de Buritirama. Para a determinação destas propriedades vários métodos foram utilizados, destacando-se: difração de raios-x,öptica petrogräfica, medidas de propriedades ōpticas na Platina Universal de Federov, e anälises químicas em microssonda eletrónica.

As texturas desses minerais acham-se descritas e ilus tradas anteriormente. As associações alëm das descrições prévias, serão novamente discutidas no item $V-1$, "Condições de metamorfismo de Buritirama".

\section{$111-3-1-$ CARBONATOS}

Medidas do îndice de refração $n_{w}$, estudo de microsson. 
da e determinações de $\Delta_{104}$, ou seja, d104(ca1cita) - d104(carbonato desconhecido), mostram que os carbonatos encontrados no protominerio são quase que inteiramente compostos por $\mathrm{MnCO}_{3}, \mathrm{CaCO}_{3}$ e. $\mathrm{MgCO}_{3} \mathrm{com}$ pequenas quantidades de $\mathrm{FeCO}_{3}$. (menos que 1 mol \%).

os valores $n_{w}$ medidos pelo mëtodo de imersão variaram de 1,675 a 1,780 enquanto que os valores de $\Delta d_{104}$, de 0,03 a 0,14 .

A Tabela I contém añ̄lises de microsisonda dos carbonatos de Buritirama em porcentagem em peso e em porcentagem molar dos componentes $\mathrm{MnCO}_{3}, \mathrm{CaCO}_{3}, \mathrm{MgCO}_{3}$ e $\mathrm{FeCO}_{3}$. A razão $\mathrm{Ca} / \mathrm{Mn}$ apresenta grande variação em diferentes amostras, variando pouco porēm entre grãos de uma mesma lâmina. A quantidade de Mg estā relacionada com a razão $C a / M n$. Quanto maior a relação $C a / M n$, tanto menor ē o conteüdo de $M g$ devido à substituição isomorfa do Ca pe $10 \mathrm{Mg}$.

Comparando-se as composições dos carbonatos encontrados no protominërio, que pertencem ao sistema $\mathrm{MnCO}_{3}-\mathrm{CaCO}_{3}$ $\mathrm{MgCO}_{3} \mathrm{com}$ os dados de GOLDSMITH \& GRAF (1957) para o sistema $\mathrm{MnCO}_{3}, \mathrm{CaCO}_{3}$, nota-se que, acima de $500^{\circ} \mathrm{C}$, a maioria deles $\because$ estä dentro da região de completa miscibilidade, que extende-se do $\mathrm{CaCO}_{3}$ até $\mathrm{Ca}_{0,42} \mathrm{Mn}_{0,58} \mathrm{CO}_{3}$. (Figura 6).

Em uma amostra foram encontrados carbonatos coexistentes com composições: $\mathrm{Ca}_{0,19} \mathrm{Mn}_{0,70} \mathrm{Mg}_{0,11} \mathrm{CO}_{3}$ e $\mathrm{Ca}_{0,29} \mathrm{Mn}_{0,60}$

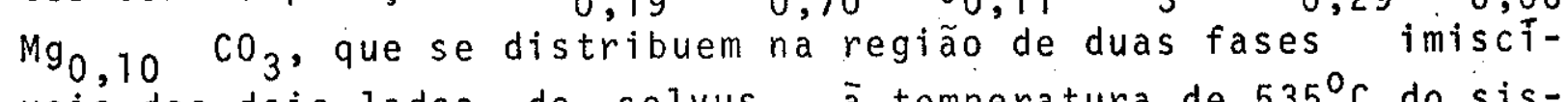
veis dos dois lados do solvus à temperatura de $535^{\circ} \mathrm{C}$ do sistema puro $\mathrm{MnCO}_{3}-\mathrm{CaCO}_{3}$. E possivel no entanto que o conteüdo em $\mathrm{Mg}$ e $\mathrm{Fe}$ desses carbonatos faça com que o solvus "do sistema $\mathrm{Ca}-\mathrm{Mn}-\mathrm{Mg}-\mathrm{Fe}-\mathrm{CO}_{3}$ encontre-se à temperatura mais elevada, como será discutido adiante. (Figura 28 ).

\section{$|1|-3-2-$ PIROXMANGITA}

Entre os piroxenöides manganesíferos a piroxmangita 
TABELA I - ANALISES DE MICROSSONDA DE CARBONATOS DE PROTOMINERIOS DE Mn DE BURITIRAMA

Peso \%

AMOSTRA NO $\quad \mathrm{MnCO}_{3} \quad \mathrm{CaCO}_{3} \quad \mathrm{MgCO}_{3} \quad \mathrm{FeCO}_{3}$

$B 5-14-80,8 \cdot I$

B5 $-14-80,8$ I I

B5-14-80,8 III

B5 $-10-80,2$ I

B5 $-10-80,2$ II

$\mathrm{B} 5-10-80,2$ I I I

B5-10-92,0 I

B 5-10-92,0 II

B5-10-97, 8 I I

B5-14-67, I I

B5-14-67, I I I

B5-14-69,9 I

B5-14-69,9 II

B5-14-72,0 I

B 5-14-72,0 II

B5-14-72,0 III

B5-14-72,0 IV

B5-14-78,8 I

B5-14-78,8 II

B5-14-78,8 III

B 5-14-78, 8 IV

B5-22-64,6 I

B5-22-64,6 II

B5-22-64,6 II I

B5-22-64,6 IV

B5-22-65, 8 I

B 5-22-65, 8 II

$\mathrm{B} 5-22-65,8$ III

B 5-22-65,8 IV
$64,2 \quad 26,3 \quad 7,8 \quad 0,7$

$64,4 \quad 25,7 \quad 7,5 \quad 0,7$

$71,9 \quad 16,9 \quad 8,3 \quad 0,7$

$19,1 \quad 77,2 \quad 2,6 \quad 0,2$

$19,3 \quad 73,3$

$16,3.82,8$

$20,8 \quad 78,3$

$20,1 \quad 82,1$

$11,790,3$

$50,4 \quad 38,9$

$51,5 \quad 38,9$

$45,2^{\circ} \quad 47,5$

$44,1 \quad 47,5$

52,4

$51,136,3$

52,0

52,1

50,2

49,1

49,0

51,0

39,8

38,8

38,0

39,0

40,9

41,2

42,0

38,9
37,4

3,1

1,3

1,9

1,1

0,4

8,3

8,0

5,8

5,7

0,2

nd

nd

nd

nd

0,7

0,7

0,7

0,7

3,2

0,7

9,0

0,6

9,0

0,6

9,1

0,6

8,7

0,7

8,6

0,7

8,7

0,7

8,7

0,7

6,6

0,6

6,5

0,6

52,4

6,5

0,6

52,0

6,5

0,6

50,5

7,1

0,7

6,7

0,7

7,6

0,7

0,7
Mol. \%

$\begin{array}{lllll}\mathrm{MnCO}_{3} & \mathrm{CaCO}_{3} & \mathrm{MgCO}_{3} & \mathrm{FeCO}_{3}\end{array}$

$60,7 \quad 28,6 \cdots \quad 10,1 \quad 0,6$

$61,5 \quad 28,1 \quad 9,8 \quad 0,6$

$69,6 \quad 18,7 \quad 11,0 \quad 0,6$

$17,1 \quad 79,5 \quad 3,2 \quad 0,2$

$18,3 \quad 79,7 \quad 3,9 \quad 0,2$

$14,4 \quad 84,1 \quad 1,5 \quad-$

$18,3 \quad 79,2 \quad 2,3 \quad-$

$17,3 \quad 81,4 \quad 1,3 \quad$ -

$10,1 \quad 89,4 \quad 0,5$

$47,1 \quad 41,7 \quad 10,6 \quad 0,6$

$\begin{array}{llll}47,8 & 41,5 & 10,1 & 0,6\end{array}$

$41,8 \quad 50,3 \quad 7,3 \quad 0,6$

$41,2 \quad 51,0 \quad 7,2 \quad 0,6$

$\begin{array}{llll}48,3 & 39,6 & 11,6 & 0,6\end{array}$

$48,4 \quad 39,5 \quad 11,6 \quad 0,6$

$49,1 \quad 38,7 \quad 11,6 \quad 0,6$

$48,7 \quad 39,2 \quad 11,5 \quad 0,6$

$\begin{array}{llll}46,8 & 41,5 & 11,0 & 0,6\end{array}$

$45,5 \quad 43,0 \quad 10,8 \quad 0,6$

$45,2: 43,2 \quad 11,0 \quad 0,6$

$47,7 \quad 40,6 \quad 11,1 \quad 0,6$

$36,0 \quad 55,3 \quad 8,1 \quad 0,5$

$35,4 \quad 56,0 \quad 8,1 \quad 0,5$

$35,3 \quad 56,0 \quad 8,1 \quad 0,5$

$35,7 \quad 55,6 \quad 8,1 \quad 0,6$

$37,4 \quad 53,1 \quad 8,9 \quad 0,6$

$37,5 \quad 53,5 \quad 8,3 \quad 0,6$

$\begin{array}{llll}37,8 & 51,9 & 9,6 & 0,7\end{array}$

$35,5 \quad 55,7 \quad 8,1 \quad 0,7$ 


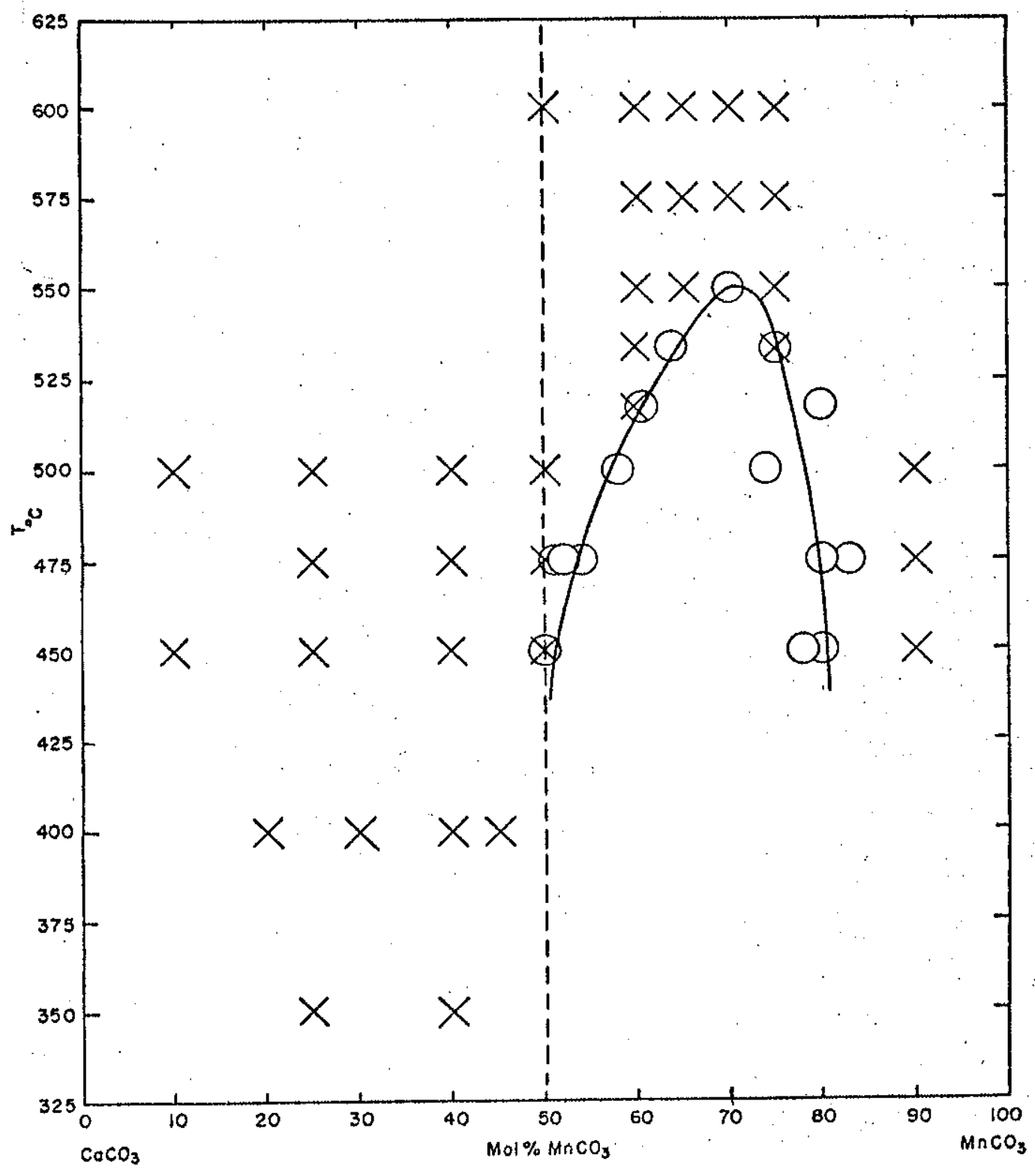

Figura 6 - Solução sōlida no sistema $\mathrm{CaCO}_{3}-\mathrm{MnCO}_{3}$ segundo GOLDSMITH \& GRAF, 1957. 
encontrada com mais frequéncia no protominërio, ocorrendo sempre associada a carbonatos mais ricos em $M n$ o que pode ser visto nas Figuras 7 e 27 . e Foto 30 entre outras. Foram efetuadas 27 medidas de propriedades ōpticas, em seis lâminas delgadas que continham esse piroxenōide. A variação encontrada para o valor do àngulo axial $2 \mathrm{~V}$ foi de $40,0^{\circ}$ a $47,0^{\circ}$. valores de $\gamma \wedge z$ variaram de $37,0^{\circ}$, a $43,0^{\circ}$ e o āngulo entre as citivagens (110) e (1TO) entre 89,5 e $92,0^{\circ}$ (Ta bela VIII).

A Tabela II contēm os dados das anälises de microssonda eletrōnica de piroxmangitas. Dela constam porcentagem em peso de $\mathrm{SiO}_{2}, \mathrm{MnO}$, $\mathrm{CaO}, \mathrm{MgO}$ e FeO bem como nümero de ions com base em 3 oxigenios $\left(\mathrm{M}^{2+} \mathrm{SiO}_{3}\right)$.

Pela anälise da Tabela II e da Figura 7 ve-se que 0 conteūdo molar de $\mathrm{CaS}_{3}{ }_{3}$ nas piroxmangitas apresenta pouca varia ção enquanto que $\mathrm{MnSiO}_{3}, \mathrm{FeSiO}_{3}$ e $\mathrm{MgSiO}_{3}$ variam consideravelmente.

\section{$111-3-3-$ RODONITA}

Ocorre em veios e também como mineral formador de rocha. (Foto 32).

Foram efetuadas sete medidas de propriedades öpticas atravēs de Platina Universal sendo os dados apresentados na Tabe la VIII. 0 àngulo axial $2 V_{z}$ varia de $62,0^{\circ}$ a $64,0^{\circ} ; \gamma \Lambda z$ varia de $36,0^{\circ}$ a $40,0^{\circ}$ e os āngulos entre as clivagens $(110)$ e (1T0) variam de $88,0^{\circ}$. a $91,5^{\circ}$.

As anälises de microssonda eletrōnica. Tabela II, mostram uma variação no seu conteūdo de $\mathrm{CaSiO}_{3}$ de 9 a 11 . mol \% sendo que o conteūdo em $\mathrm{MgSiO}_{3}$ e $\mathrm{FeSiO}_{3}$ não excede 15 mol \%.

Pela Figura 7 constata-se ainda que a rodonita é mais rica em ca que a piroxmangita, coexiste com carbonatos mais ricos em cálcio, (Figura 7 e 27), e às vezes tambëm com clinopiro-. 


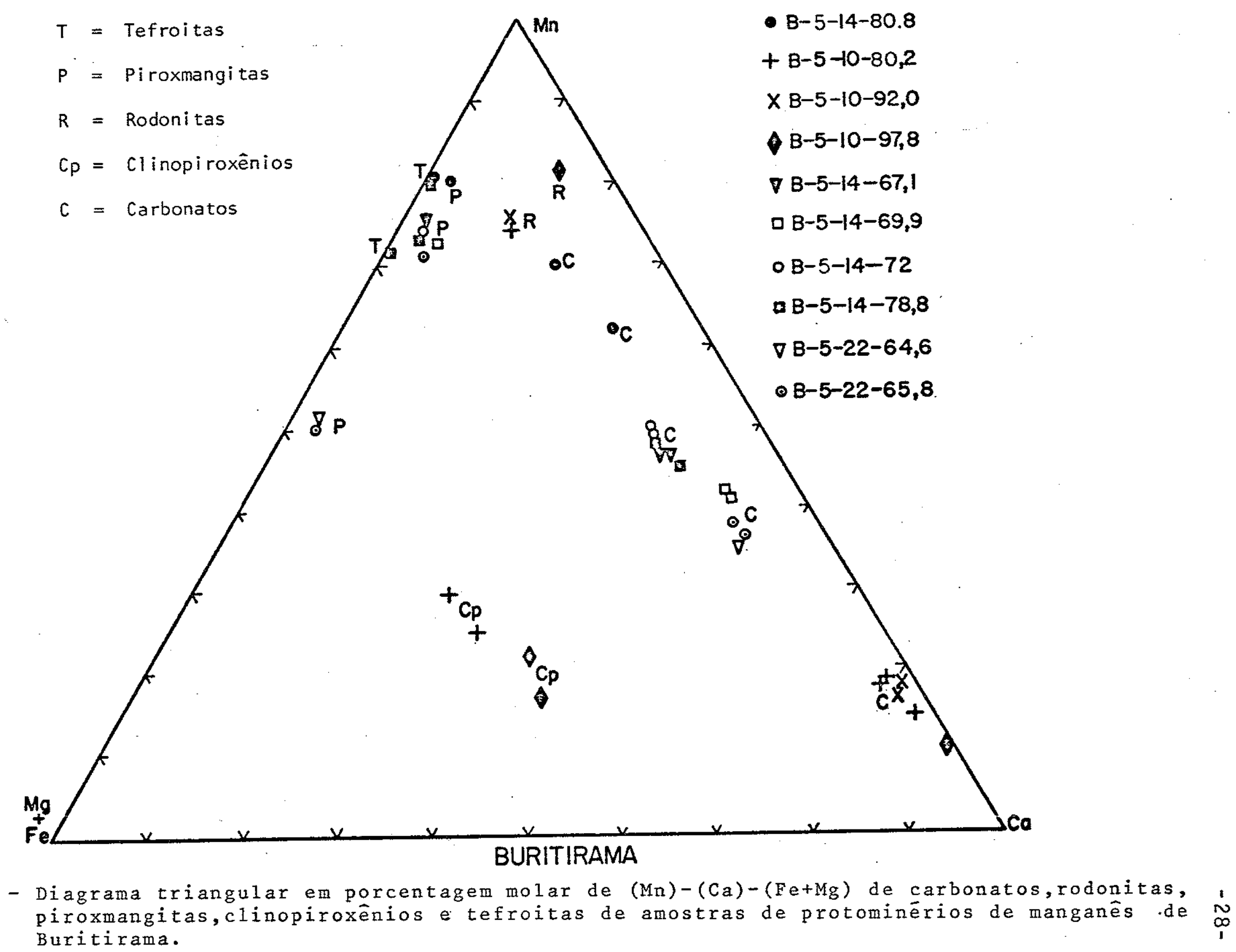


TABELA II - ANALISES DE MICROSSSONDA DE PIROXENOIDES DE PROTOMINERIOS DE Mn DE BURITIRAMA

\begin{tabular}{|c|c|c|c|c|c|c|c|c|c|c|}
\hline & & & Peso & & & Nümero & ions & com base & em 3 os & gênios \\
\hline AMOSTRA NO & $\mathrm{SiO}_{2}$ & Mno & $\mathrm{CaO}$ & $\mathrm{MgO}$ & $\mathrm{FeO}$ & Si & $M n$ & $\mathrm{Ca}$ & $\mathrm{Mg}$ & $\mathrm{Fe}$ \\
\hline & & & & Pirox & tas & & & & & \\
\hline B5-14-80,8 III & 47,71 & 44,52 & 1,09 & 5,73 & 0,95 & 1,00 & 0,79 & 0,03 & 0,18 & 0,02 \\
\hline$B 5-14-67,1 \mathrm{I}$ & 49,76 & 42,57 & 1,45 & 6,31 & 1,46 & 1,01 & 0,73 & 0,03 & 0,19 & 0,02 \\
\hline B5-14-67,1 II & 48,18 & 42,66 & 1,47 & 6,49 & 1,34 & 1,00 & 0,75 & 0,03 & 0,20 & 0,02 \\
\hline$B 5-14-69,9$ I & 48,92 & 41,78 & 2,09 & 6,23 & 1,86 & 1,00 & 0,73 & 0,05 & 0,19 & 0,03 \\
\hline B5-14-72,0 I & 49,53 & 42,40 & 1,43 & 6,88 & 1,34 & 1,00 & 0,74 & 0,03 & 0,21 & 0,02 \\
\hline $\mathrm{B} 5-14-72,0 \mathrm{II}$ & 48,18 & 42,44 & 1,43 & 7,13 & 1,30 & 0,99 & 0,74 & 0,03 & 0,22 & 0,03 \\
\hline B5-14-72,0 IV & 48,72 & 42,51 & 1,39 & 6,55 & 1,30 & 1,00 & 0,73 & 0,03 & 0,20 & 0,02 \\
\hline B5-14-78,8 II & 48,19 & 42,88 & 1,57 & 6,75 & 1,28 & 0,99 & 0,75 & 0,03 & 0,21 & 0,03 \\
\hline B5-14-78,8 III & 48,06 & 42,06 & 1,41 & 7,31 & 1,29 & 0,99 & 0,74 & 0,03 & 0,23 & 0,02 \\
\hline B5-14-78,8 IV & 47,83 & 42,22 & 1,38 & 7,36 & 1,26 & 0,99 & 0,74 & 0,03 & 0,23 & 0,02 \\
\hline B5-22-64,6 II & 52,62 & 30,17 & 1,70 & 14,98 & 1,62 & 1,01 & 0,49 & 0,03 & 0,43 & 0,03 \\
\hline B5-22-64,6 IV & 52,75 & 30,41 & 1,61 & 14,50 & 1,65 & 1,01 & 0,49 & 0,03 & 0,43 & 0,03 \\
\hline$B 5-22-65,8$ I & 52,28 & 30,58 & 1,46 & 14,97 & 1,77 & 1,01 & 0,50 & 0,03 & 0,42 & 0,03 \\
\hline B5-22-65,8 II & 50,10 & 41,18 & 1,72 & 6,82 & 1,84 & 1,01 & 0,70 & 0,04 & 0,21 & 0,03 \\
\hline$B 5-22-65,8$ IV & 50,21 & 41,37 & 1,94 & 6,44 & 1,94 & 1,01 & 0,71 & 0,04 & 0,19 & 0,02 \\
\hline & & & . & Rodo & & & & & & \\
\hline B5-10-80,2 I I & 48,93 & 41,63 & 5,01 & 4,50 & 0,62 & 1,01 & 0,73 & 0,11 & 0,14 & 0,01 \\
\hline $\mathrm{B} 5-10-92,0 \mathrm{I}$ & 45,84 & 42,99 & 4.83 & 4,15 & 0,05 & 0,99 & 0,77 & 0,11 & 0,13 & 0,01 \\
\hline $\mathrm{B} 5-10-97,8$ IV & 48,51 & 45,02 & 6,00 & 1,61 & 0,15 & 1,01 & 0,79 & 0,13 & 0,05 & 0,00 \\
\hline
\end{tabular}


xênio rico em manganès.

\section{1 - 3 - 4 - CLINOPIROXENIOS MANGANESífEROS}

Ocorrem associados a rodonita e a carbonatos mais ricos em cālcio da série calcita-kutnahorita (Figura 7). Efetuaram-se 22 determinações ópticas em Platina Universal tendo sido encontradas as seguintes variações:

àngulo $2 \mathrm{~V}$ : de $50,0^{\circ}$ a $60,0^{\circ}$

āngulo entre $\gamma$ e $z$ : de $37,0^{\circ}$ a $40,0^{\circ}$

ângulo entre as clivagens $(110)$ e $(1 \mathrm{TO})$ : de $86,0^{\circ}$ a $94,0^{\circ}$. Tabela VIII.

Pela Tabela III vemos que seu conteūdo em Fe e Mg è razoavelmente constante e que a razão $\mathrm{Mn} / \mathrm{Ca}$ varia consideravelmente.

Anālises feitas com raios- $X$, mostram padrão de difração quase indistinguĩvel da johansenita.

\section{$111-3-5-$ TEFROITA}

Aparece predominantemente como cristais poiquiloblästicos orientados às vezes com dimensões maiores que $3 \mathrm{~mm}$, englobando carbonatos, granadas e às vezes piroxenöides. (Fotos 27, 28 e 29).

Medidas em Platina Universal forneceram para 5 grãos, as seguintes variações:

Ânguto $2 V_{X}$ :de $62,0^{\circ}$ a $69,0^{\circ}$. As clivagens geralmente apre sentaram-se mal definidas havendo variação nos ângulos de $86,0^{\circ}$ a $88,0^{\circ}$ (Tabela IX).

A Tabela IV apresenta as anālises de microssonda das. 
TABELA III - ANALISES DE MICROSSONDA DE CLINOPIROXENIOS DE PROTOMINERIOS DE Mn DE BURITIRAMA

\begin{tabular}{|c|c|c|c|c|c|c|c|c|}
\hline AMOSTRA & No & $\mathrm{SiO}_{2}$ & $\mathrm{MnO}$ & $\mathrm{CaO}$ & MgO & FeO & $\mathrm{Al}_{2} \mathrm{O}_{3}$ & $\mathrm{Na}_{2} \mathrm{O}$ \\
\hline$B 5-10-80,2$ & $I$ & 53,00 & 14,93 & 15,62 & 14,90 & 1,02 & 0,23 & 0,24 \\
\hline$B 5-10-80,2$ & II & 53,31 & 14,60 & 12,37 & 14,60 & 1,33 & 0,12 & - \\
\hline$B 5-10-97,8$ & II & 53,69 & 13,25 & 19,42 & 13,66 & 0,17 & 0,10 & - \\
\hline$B 5-10-97,8$ & IV & 54,07 & 11,37 & 20,43 & 14,36 & 0,12 & 0,07 & - \\
\hline
\end{tabular}

Nümero de ions com base em 3 oxigēnios

\begin{tabular}{|c|c|c|c|c|c|c|c|c|}
\hline AMOSTRA & NO & $\mathrm{Si}$ & $M n$ & $\mathrm{Ca}$ & $\mathrm{Mg}$ & $\mathrm{Fe}$ & Al & $\mathrm{Na}$ \\
\hline B $5-10-80,2$ & I & 1,00 & 0,24 & 0,32 & 0,42 & 0,02 & 0,01 & 0,01 \\
\hline B5 $5-10-80,2$ & II & 1,01 & 0,29 & 0,25 & 0,41 & 0,02 & - & - \\
\hline$B 5-10-97,8$ & II & 1,01 & 0,21 & 0,39 & 0,38 & - & - & - \\
\hline B $5-10-97,8$ & IV & 1,01 & 0,18 & 0,40 & 0,40 & - & - & - \\
\hline
\end{tabular}


TABELA IV - ANĀLISES DE MICROOSSONDA DE TEFROITAS DE PROTOMINERIOS DE Mn DE BURITIRAMA Peso \%

\begin{tabular}{|c|c|c|c|c|c|c|c|}
\hline \multicolumn{2}{|c|}{ AMOSTRA NO } & $\mathrm{SiO}_{2}$ & Mno & $\mathrm{CaO}$ & $\mathrm{MgO}$ & FeO & $\mathrm{ZnO}$ \\
\hline B $5-14-80,8$ & I & 30,68 & 59,37 & 0,06 & 6,24 & 3,49 & nd \\
\hline$B 5-14-80,8$ & I I & 30,90 & 59,37 & 0,08 & 6,38 & 3,42 & nd \\
\hline$B 5-14-80,8$ & III & 31,64 & 58,98 & 0,07 & 6,73 & 3,55 & nd \\
\hline B5-74-78,8 & $I$ & 31,56 & 54,16 & 0,06 & 9,93 & 4,46 & 0,16 \\
\hline B5-14-78,8 & II & 30,96 & 54,41 & 0,07 & 9,70 & 4,72 & 0,12 \\
\hline B $5-14-78,8$ & III & 31,29 & 54,00 & 0,07 & 9,98 & 4,63 & 0,21 \\
\hline B $5-74-78,8$ & IV & 31,02 & 53,40 & 0,06 & 9,49 & 4,58 & 0,22 \\
\hline
\end{tabular}

Nümero de ions com base em 4 oxigēnios

\begin{tabular}{clcccccc}
\multicolumn{2}{c}{ AMOSTRA NO } & Si & Mn & Ca & Mg & Fe & Zn \\
B5-14-80,8 I & 0,99 & 1,61 & - & 0,30 & 0,09 & - \\
B5-14-80,8 II & 0,99 & 1,60 & - & 0,31 & 0,09 & - \\
B5-14-80,8 III & 1,00 & 1,60 & - & 0,31 & 0,09 & - \\
B5-14-78,8 I & 0,99 & 1,42 & - & 0,46 & 0,12 & - \\
B5-14-78,8 II & 0,98 & 1,42 & - & 0,45 & 0,12 & 0,12 \\
B5-14-78,8 III & 0,98 & 1,41 & - & 0,46 & 0,12 & 0,01 \\
B5-14-78,8 IV & 0,97 & 1,42 & - & 0,45 & 01
\end{tabular}


olivinas: alēm de $\mathrm{Mn}_{2} \mathrm{SiO}_{4}$, as tefroitas tambëm apresentam $15 \mathrm{~mol}$ $\%$ de $\mathrm{Mg}_{2} \mathrm{SiO}_{4}$ (forsterita) e pequena quantidade de $\mathrm{Fe}_{2} \mathrm{SiO}_{4}$ (faialita) e de $\mathrm{Ca}_{2} \mathrm{SiO}_{4}(1 \mathrm{arnita})$.

Nas anālises de raios-X, o teor cie forsterita é detectado, observando-se um deslocamento considerävel nas reflexões, no sentido de valores mais baixos de $d(h k 1)$ do que os da tefroita pura $\left(\mathrm{Mn}_{2} \mathrm{SiO}_{4}\right)$.

A tefroita ē mineral comum tanto nos protominērios de Buritirama como em outros protominērios carbonäticos de manganês de Serra do Navio e de Lafaiete. Em todos os casos ela deve ser denominada de picrotefroita segundo alguns autores (CASTRO,1960).

\section{$111-3-6$ - ANFIBOLIOS MANGANES IFEROS}

Esses minerais são geralmente formados em partes rocha onde a pressão parcial de ägua foi alta. Podem ser classificados como cummingtonita rica em Mn ou como uma danemorita rica em Mg. (Foto 7). Tambēm foram observados anfibōlios manganesi feros da série tremolita-actinolita (amostra B5-10-92,0m).

Estudos öpticos de anfibölios forneceram valores do ân gulo axial $2 V_{x}$ prōximos de $85^{\circ}$. São minerais incolores, raramente apresentando cor amarela. Geminação polissintëtica tambēm foi observada em alguns anfibolios. De maneira geral, sua formação parece ser relacionada a alteração de piroxenöides e piroxénios associados a veios carbonáticos.

A ação de fases hidrotermais pegmatiticas $\bar{e}$ sugerida pela presença de veios de quartzo dentro dos micaxistos situados a NE das ocorrēncias manganesifferas.

Em Buritirama conforme a variação dos teores de $\mathrm{Ca}, \mathrm{Mg}$, $\mathrm{Fe}, \mathrm{Mn}, \mathrm{Al}_{2} \mathrm{O}_{3}$ e $\mathrm{H}_{2} \mathrm{O}$ pode-se prever a formação de clinopiroxênios normais ao lado da rodonita (Mn, $\mathrm{Ca}, \mathrm{Fe}) \mathrm{SiO}_{3}$ (ABRECHT \& PETERS, 1975), carbonatos e minerais hidratados tais como anfibölios e flogopitas (VALARELLI \& CROSTA, 1977). 
os dados de microssonda eletrónica dos anfibōlios ana lisados acham-se apresentados na Tabela $V$.

\section{$111-3-7-$ GRANADAS}

A granada encontrada nos protominérios de Buritirama e a espessartita, usualmente com pequenas proporções de grossularia, piropo, almandina e andradita. Os dados de microssonda eletrōnica dessas granadas encontram-se na Tabela VI.

Elas ocorrem intimamente associadas a carbonatos como pequenas inclusões nesses minerais ou ainda muitas vezes ocorrem como hospedeiros de fragmentos carbonäticos. (Fotos 19 a 21 , 25 e 30$)$.

Granadas de granulação grosseira estão geralmente as sociadas a partes mais ricas em piroxenóides.

Medidas dos indices de refração forneceram valores en tre 1,817 e 1,790 indicando tratar-se do membro final espessartita.

Estudos de raios-X forneceram variação do parāmetro da cela unitäria entre 11,570 e $11,634 \mathrm{~A}$, confirmando os dados acima.

\section{$111-3-8$ - FLOGOPITA MANGANESTFERA}

Flogopita de manganēs ē uma fase hidratada comum em grande parte das associações estudadas. (Fotos 8, 11, 12, 19,20, 22, 23, 24 e 25). 0corre como placas possuindo förmula pleocrói ca: $X=$ castanha clara; $Y=$ rosada ou castanha pälida: $Z$ = ama rela esverdeada. Seu āngulo axial $2 V_{x}$ tem um valor aproximado de $35^{0}$. 
TABELA $V$ - ANÁLISES DE MICROSSONDA DE ANFIBÓliOS DE PROTOMINERIOS DE Mn DE BURITIRAMA

\begin{tabular}{|c|c|c|c|c|c|c|c|c|c|}
\hline & & & & & $\%$ & & & & \\
\hline AMOSTRA & & $\mathrm{SiO}_{2}$ & $\mathrm{Al}_{2} \mathrm{O}_{3}$ & $\mathrm{CaO}$ & $\mathrm{MgO}$ & $\mathrm{MnO}$ & $\mathrm{FeO}$ & $\mathrm{TiO}_{2}$ & $\mathrm{Na}_{2} \mathrm{O}$ \\
\hline$B 5-10-92,0$ & II & 56,87 & 0,06 & 11,19 & 21,99 & 5,83 & - & - & 0,34 \\
\hline$B 5-14-69,9$ & & 56,43 & 0,06 & 0,85 & 20,06 & 18,70 & 2,41 & - & 0,05 \\
\hline$B 5-22-64,6$ & I & 54,38 & 0,19 & 0,92 & 19,46 & 79,94 & 2,17 & - & 0,08 \\
\hline$B 5-22-64,6$ & IV & 56,36 & 0,14 & 0,91 & 19,44 & 19,14 & 2,17 & - & - \\
\hline
\end{tabular}

Nümero de ions com base em 23 oxigēnios

$\begin{array}{ccccccccr}\text { AMOSTRA NO } & \text { Si } & \text { Ai } & \text { Ca } & \text { Mg } & \text { Mn } & \text { Fe } & \text { Ti } & \text { Na } \\ \text { B5-10-92,0 II } & 7,99 & 0,01 & 1,68 & 4,60 & 0,69 & - & 0,09 \\ \text { B5-14-69,9 } & 8,03 & 0,01 & 0,13 & 4,25 & 2,25 & 0,29 & - \\ \text { B5-22-64,6 I } & 7,92 & 0,03 & 0,14 & 4,22 & 2,46 & 0,26 & - & 0,02 \\ \text { B5-22-64,6 IV } & 7,99 & 0,02 & 0,14 & 4,18 & 2,30 & 0,26 & - & -\end{array}$


TABELA VI - ANALISES DE MICROSSONDA DE ESPESSARTITAS DE PROTOMINERIOS DE Mn DE BURITIRAMA

Peso \%

AMOSTRA NO $\quad \mathrm{SiO}_{2} \quad \mathrm{Al}_{2} \mathrm{O}_{3} \quad \mathrm{MnO} \quad \mathrm{CaO} \quad \mathrm{MgO} \quad \mathrm{FeO} \quad \mathrm{TiO}_{2}$

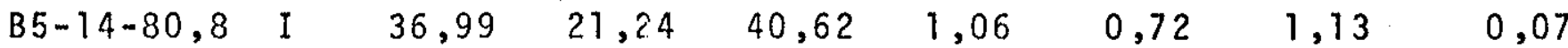

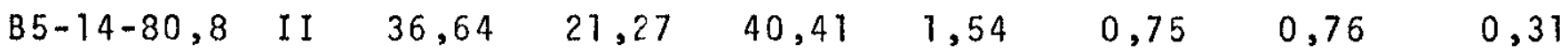

B5-10-80,2 I $37,39 \quad 18,92 \quad 34,92 \quad 4,66 \quad 1,80 \quad 3,30$ nd

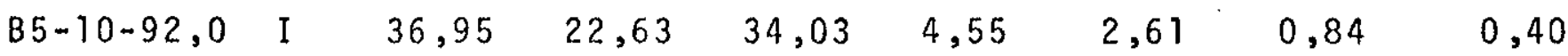

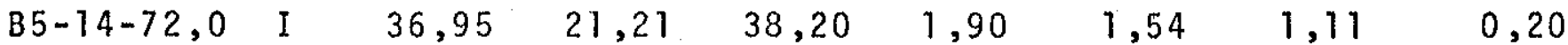

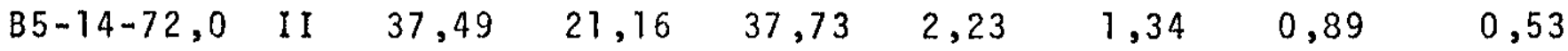

B5-14-72,0 IV $37,78 \quad 21,13 \quad 38,60 \quad 1,66 \quad 1,19 \quad 1,13 \quad$ nd

$\begin{array}{llllllll}B 5-14-78,8 \quad I & 37,67 & 21,29 & 39,27 & 2,00 & 1,14 & 1,03 & 0,28\end{array}$

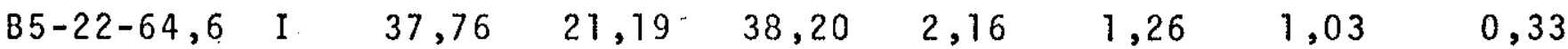

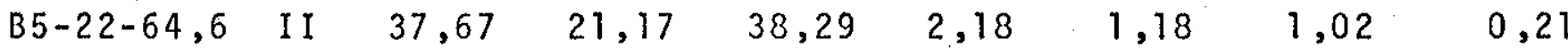

B5-22-64,6 III $37,54 \quad 21,18 \quad 37,94 \quad 2,26 \quad 1,23 \quad 1,03 \quad$ nd

B5-22-65,8 I $\quad 37,36 \quad 21,24 \quad 38,66 \quad 2,12 \quad 1,06 \quad 1,19 \quad$ nd

$\begin{array}{llllllll}B 5-22-65,8 & V & 38,04 & 21,28 & 38,27 & 2,10 & 1,09 & 1,25\end{array}$

Nümero de ions com base em 12 oxigênios

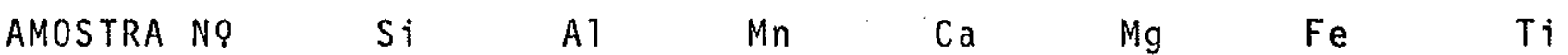

$\begin{array}{llllllllc}\text { B5-14-80,8 } & \text { I } & 2,98 & 2,02 & 2,77 & 0,09 & 0,09 & 0,08 & - \\ \text { B5-14-80,8 } & \text { II } & 2,96 & 2,03 & 2,77 & 0,13 & 0,09 & 0,05 & 0,02 \\ \text { B5-10-80,2 } & \text { I } & 3,03 & 1,81 & 2,39 & 0,40 & 0,22 & 0,22 & - \\ \text { B5-10-92,0 } & \text { I } & 2,90 & 2,09 & 2,26 & 0,42 & 0,30 & 0,05 & 0,02 \\ \text { B5-14-72,0 } & \text { I } & 2,98 & 2,01 & 2,61 & 0,16 & 0,18 & 0,07 & 0,01 \\ \text { B5-14-72,0 } & \text { II } & 3,01 & 2,00 & 2,56 & 0,19 & 0,16 & 0,06 & 0,03 \\ \text { B5-14-72,0 } & \text { IV } & 3,02 & 1,99 & 2,61 & 0,14 & 0,14 & 0,08 & - \\ \text { B5-14-78,8 } & \text { I } & 2,98 & 2,00 & 2,63 & 0,17 & 0,13 & 0,07 & 0,03 \\ \text { B5-22-64,6 } & \text { I } & 3,01 & 1,99 & 2,58 & 0,19 & 0,15 & 0,07 & 0,02 \\ \text { B5-22-64,6 } & \text { II } & 3,00 & 2,00 & 2,60 & 0,19 & 0,14 & 0,07 & 0,01 \\ \text { B5-22-64,6 } & \text { III } & 3,01 & 2,00 & 2,57 & 0,19 & 0,15 & 0,07 & - \\ \text { B5-22-65,8 } & \text { I } & 2,99 & 2,00 & 2,62 & 0,18 & 0,13 & 0,08 & - \\ \text { B5-22-65,8 } & \text { V } & 3,02 & 1,99 & 2,58 & 0,18 & 0,13 & 0,08 & -\end{array}$


A Tabela VII mostra anälises de microssonda eletrónica de mangano flogopitas. Ve-se que seu conteüdo em $\mathrm{Mn}$ varia muito pouco nas diferentes amostras e seu conteüdo de Fe, que è muito baixo quando comparado ao teor de $\mathrm{Mg}$, varia bastante. Encontrou-se, em seis amostras analisadas, variação de 0,29 a 4,41, na porcentagem em peso do Fe0. A porcentagem em peso de Mgo varia de 21,73 a 23,84 e a de $\mathrm{MnO}$ de 3,42 a 6,17. Na mesma tabela, observa-se que a substituiçăo de $\mathrm{Na}^{+}$por $\mathrm{K}^{+} \overline{\mathrm{e}}$ pequena. A flogopita manganesifera foi classificada como manganofilita.

\section{$111-3-9$ - MINERAIS METALICOS}

Os minerais metälicos foram estudados opticamente,por difração de raios-X e submetidos ao estudo químico semi-quantitativo na microssonda eletrōnica.

Nos protominērios constituídos por märmores com braunita, este mineral (braunita) aparece macroscopicamente em abundãncia apre sentando um aspecto de fragmentos maciços com atē $10 \mathrm{~cm}$ cortados e/ou envolvidos por massas de carbonato+manganofilita+clinoanf bölio manganesífero. (Fotos 10 e 26). Microscopicamente, a bra nita contēm inclusões desses minerais. (Fotos $6,7,8$ e 9). Seu conteūdo em $\mathrm{SiO}_{2}$ è aproximadamente constante podendo ser representada pela förmula ideal $3 \mathrm{Mn}_{2} \mathrm{O}_{3} \cdot \mathrm{MnSiO}_{3}$.

A substituição de $\mathrm{Mn}^{3+}$ por $\mathrm{Fe}^{3+}$ e $\mathrm{Al}^{3+}$ na primeira parte da förmula assim como a de $\mathrm{Mn}^{2+}$ por $\mathrm{Ca}^{2+}$ e $\mathrm{Mg}^{2+}$ na sua se gunda parte è muito pequena.

A alabandita geralmente ocorre como grãos xenomörficos contendo um pouco de $\mathrm{Fe}^{2+}$ e traços de $\mathrm{Mg}^{2+}$ substituindo o manganès na estrutura. Foi encontrada em apenas uma amostra analisada (furo B5-14), associada ao acessōrio pirrotita, numa rocha contendo rodocrosita, tefroita e espessartita.

Esfalerita ocorre como um acessörio disseminado e con. tëm $\mathrm{Fe}$ e Mn em pequenas proporções substituindo o $\mathrm{Zn}$. Ao mfcros 
TABELA VII - ANALISES DE FLOGOPITAS MANGANESIFERAS DE PROTOMINERIOS DE Mn DE BURITIRAMA

\begin{tabular}{|c|c|c|c|c|c|c|c|c|c|c|}
\hline \multicolumn{2}{|c|}{ AMOSTRA NO } & $\mathrm{SiO}_{2}$ & $\mathrm{Al}_{2}{ }^{\mathrm{O}} 3$ & $\mathrm{CaO}$ & $\begin{array}{l}50 \\
\mathrm{MgO}\end{array}$ & MnO & $\mathrm{FeO}$ & $\mathrm{K}_{2} \mathrm{O}$ & $\mathrm{Na}_{2} \mathrm{O}$ & $\mathrm{TiO}_{2}$ \\
\hline B $5-10-80,1$ & I & 39,41 & 12,97 & 0,051 & 21,73 & 3,96 & 4,41 & 10,20 & 0,04 & 2,08 \\
\hline$B 5-10-92,0$ & $V$ & 39,10 & 13,37 & - & 22,25 & 7,85 & 0,29 & 10,12 & 0,09 & 0,69 \\
\hline$B 5-10-94,5$ & I & 39,17 & 14,29 & - & 21,93 & 6,17 & 0,33 & 10,16 & 0,07 & 0,55 \\
\hline $85-14-67,1$ & $I$ & 39,16 & 13,78 & - & 23,45 & 4,11 & 2,00 & 8,72 & 0,49 & 0,52 \\
\hline$B 5-14-72,0$ & III & 39,15 & 13,27 & - & 23,84 & 3,56 & 1,74 & 8,34 & 0,40 & 0,84 \\
\hline$B 5-22-64,6$ & II & 39,34 & 12,60 & 0,04 & 23,46 & 3,42 & 2,14 & 9,19 & 0,19 & 1,39 \\
\hline
\end{tabular}

Nümero de ions com base em 22 oxigēnios

\begin{tabular}{cccccccccccc}
\multicolumn{1}{c}{ AMOSTRA No } & Si & A 1 & Ca & Mg & Mn & Fe & K & Na & Ti \\
B5-10-80,1 I & 5,74 & 2,23 & 0,01 & 4,73 & 0,47 & 0,54 & 1,89 & 0,01 & 0,23 \\
B5-10-92,0 & V & 5,74 & 2,31 & - & 4,87 & 0,98 & 0,04 & 1,90 & 0,03 & 0,08 \\
B5-10-94,5 & I & 5,76 & 2,48 & - & 4,82 & 0,77 & 0,04 & 1,90 & 0,02 & 0,06 \\
B5-14-67,1 & I & 5,74 & 2,38 & - & 5,13 & 0,51 & 0,25 & 1,63 & 0,14 & 0,06 \\
B5-14-72,0 & III & 5,76 & 2,30 & - & 5,23 & 0,44 & 0,21 & 1,68 & 0,11 & 0,03 \\
B5-22-64,6 & II & 5,79 & 2,19 & 0,01 & 5,15 & 0,43 & 0,26 & 1,73 & 0,05 & 0,13
\end{tabular}


cópio apresenta cor vermelha, sendo facilmente confundida com pi rofanita $\left(\mathrm{MnTiO}_{3}\right)$ que constitui acessōrio comum nos protominerios. Anālises de microssonda de pirofanita mostram que ela contëm tambëm pequenas quantidades de $\mathrm{CaO}$ e de $\mathrm{Fe} 0$.

Hausmanita constitui um acessório raro encontrado no

protominērio constitữ do por mārmores com braunita. Anālise de microssonda constatou $5 \mathrm{~mol} \%$ de $\mathrm{Fe}_{2} \mathrm{O}_{3}$ em sua composição. 
tabela VIII - dados opticos de piroxenoides E Clinopiroxenios de protominerios de Mn

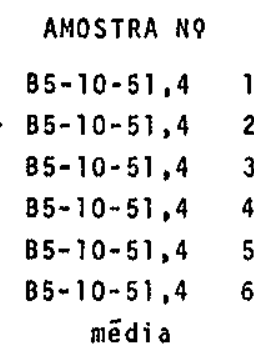

$85-10-89,6 \quad 1$

B5- $10-89,6 \quad 2$

B5-10-89,6 3

B5-10-89,6 4

mëdia

$B 5-10-92,0 \quad 1$

$B 5-10-92,02$

B5-10-92,0 3

B5-10-92,0 4

B5.10.92,0 5

mëdia

B5-14-67, 1

$85-14-67,12$

B5-14-67, 3

B5-14-67, 14

B5-14-67, 5

B5-14-67,1 6

B5-14-67,17

B5-14-67, 8

B5-14-67,1,9

$B 5-14-67,110$

mëdía

$85-14-69,9 \quad 1$

$85-14-69,92$

85-14-69,9 3

85-14-69,9 4

B5-14-69,9 5

B5-14-69,9 6

B5-14-69,9 7

mëdia

$B 5-14-72,0,1$

B5-14-72,0 2

B5-14-72,0 3

B5-14-72,0 4

B5-14-72,0 5

mëdia

B5-14-78, $8 \quad 1$

B5-14-78,8 2

85-14-78,8 3

B5-14-78,8 4

B5-14-78,8 5

B5-14-78,8 6

$85-14-78,8 \quad 7$

B5-14-78,8 8

$85-14-78,89$

$B 5-14-7 B, 8 \quad 10$

mëdta

Sina 1

$B+$

$B^{+}$

$\mathrm{B}^{+}$

$B^{+}$

$\mathrm{B}^{+}$

$B^{+}$

$\mathrm{B}^{+}$

$+$

$\mathrm{B}^{+}$

$\mathrm{B}^{+}$

$\mathrm{B}^{+}$

$B^{+}$

$B^{+}$

$B^{+}$

$B^{+}$

$B^{+}$

$B^{+}$

$\mathrm{B}^{+}$

$\mathrm{B}^{+}$

$B^{+}$

$B^{+}$

$B^{+}$

$B^{+}$

$\mathrm{B}^{+}$

$B^{+}$

$\mathrm{B}^{+}$

$\mathrm{B}^{+}$

$B^{+}$

$B^{+}$

$B^{+}$

$B^{+}$

$\mathrm{B}^{+}$

$B^{+}$

$B^{+}$

$\mathrm{B}^{+}$

$B^{+}$

$B^{+}$

$B^{+}$

$B^{+}$

$B^{+}$

$B^{+}$

$B^{+}$

$\mathrm{B}^{+}$

$B^{+}$

$B^{+}$

$B^{+}$ DE BURITIRAMA

$2 V_{Y}$ Clivagem

YAz

$40,0^{\circ}$

$30,0^{\circ}$

$38,0^{\circ}$

$35,0^{\circ}$

$21.0^{\circ}$

$37,0^{\circ}$

$33,5^{\circ}$

$40,0^{\circ}$

$38,0^{\circ}$

$38,0^{\circ}$

$40,0^{\circ}$

$39,0^{\circ}$

$38,0^{\circ}$

$38,5^{\circ}$

$36,0^{\circ}$

$32,0^{\circ}$

$40,0^{\circ}$

$36,9^{\circ}$

$32,0^{\circ}$

$37,0^{\circ}$

$42,0^{\circ}$

$36,0^{\circ}$

$48,0^{\circ}$

$54,0^{\circ}$

$-$

$48,0^{\circ}$

$36,0^{\circ}$

$50,0^{\circ}$

$42,5^{\circ}$

$47.0^{\circ}$

$32,0^{\circ}$

$40,0^{\circ}$

$38,0^{\circ}$

$39,0^{\circ}$

$44,0^{\circ}$

$40,0^{\circ}$

$40,0^{\circ}$

$42,1^{\circ}$

$42,0^{\circ}$

$42,0^{\circ}$

$42,0^{\circ}$

$43,0^{\circ}$

$38,0^{\circ}$

$41.4^{\circ}$

$43,5^{\circ}$

$44,0^{\circ}$

$45,0^{\circ}$

$40,0^{\circ}$

$40,0^{\circ}$

$43,0^{\circ}$

$53,0^{\circ}$

$51,0^{\circ}$

$51,0^{\circ}$

$37,0^{\circ}$

$44,8^{\circ}$
-

$31,0^{\circ}$

$40,0^{\circ}$

$38,0^{\circ}$

$43,0^{\circ}$

$39,0^{\circ}$

$43,0^{\circ}$

$39,0^{\circ}$

$56,0^{\circ}$

$44,0^{\circ}$

$39,0^{\circ}$

$44.0^{\circ}$

$35,0^{\circ}$

$46,0^{\circ}$

$34,0^{\circ}$

$45,0^{\circ}$

$40,0^{\circ}$

$46,0^{\circ}$

$45,0^{\circ}$

$44,0^{\circ}$

$41,8^{\circ}$ $89,7^{\circ}$

\section{Mineral}

clinopiroxênio clinopiroxênio

clinopiroxēnto

clinopiroxēnio

clinoptroxênio

clinopiroxēnio

Rodonfta

Rodonita

Rodonita

Rodonita

Clinopiroxẽnto clinopiroxênio

clinopiroxênio

clinopiroxénio

clinopiroxênio

Pifoxmanglta

Piroxmangita

Piroxmangita

Piroxmanglta

Piroxmangita

Piroxmangtta

Piroxmangita

Piroxmangita

Piroxmangita

Piroxmangita

Piroxmangita

Piroxmangita

Piroxmangtta

Piroxmangita

Piroxmangita

Piroxmangita

Piroxmangita

Piroxmangta

Piroxmangita

Piroxmangita

Piroxmangita

Piroxmangita

Piroxmangita

Piroxmangita

Piroxmanglta

Piroxmanglta

Piroxmangita

Piroxmangt ta

Piroxmangita

Piroxmanglta

Piroxmangita

Piroxmangita 
TABELA IX - DADOS OPTICOS DE OLIVINAS DE PROTOMINERIOS DE Mn DE BURITIRAMA

$\begin{array}{cccccc}\text { AMOSTRA No } & \text { Sinal Jptico } & 2 V_{\alpha} & \text { Clivagem } & \text { Mineral } \\ \text { B5-14-69,9 } & 1 & \mathrm{~B}^{-} & 69,0^{\circ} & - & \text { Tefroita } \\ \mathrm{B} 5-14-78,8 & 1 & \mathrm{~B}^{-} & 58,0^{\circ} & 86,0^{\circ} & \text { Tefroita } \\ \mathrm{B} 5-14-78,8 & 2 & \mathrm{~B}^{-} & 66,0^{\circ} & 87,0^{\circ} & \text { Tefroita } \\ \mathrm{B} 5-14-78,8 & 3 & \mathrm{~B}^{-} & 65,0^{\circ} & 86,0^{\circ} & \text { Tefroita } \\ \mathrm{B} 5-14-78,8 & 4 & \mathrm{~B}^{-} & 62,0^{\circ} & 88,0^{\circ} & \text { Tefroita } \\ \text { Média } & & 62,7^{\circ} & 86,8^{\circ} & \end{array}$




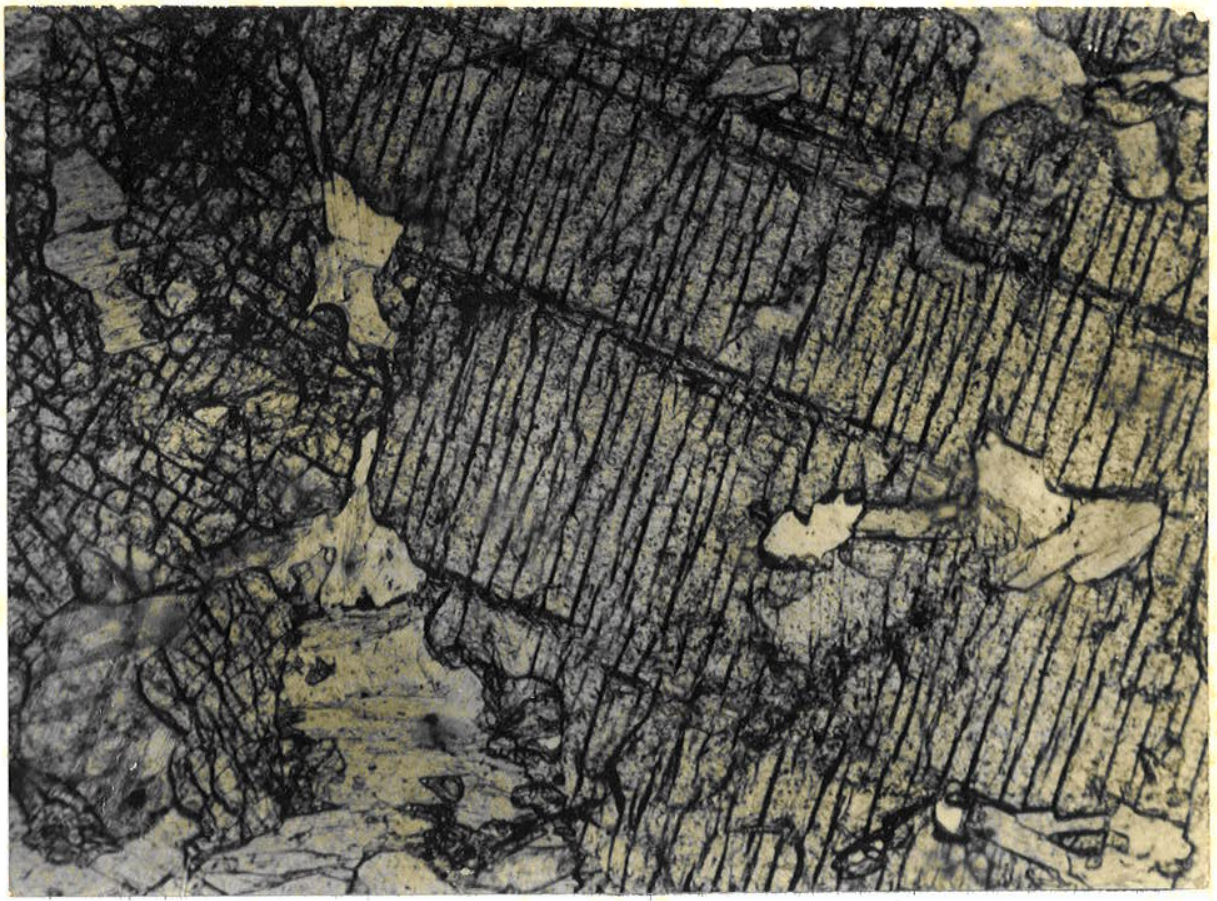

Foto 1-Calco xisto.Partes em que a rocha apresenta granulação mais grosseira com macrocristais de clinopiroxênios com inclusões poiquilíticas de carbona to e flogopita associado a carbonato e flogopita. Amostra B5-10(505) $113,6 \overline{4}$ $-113,69 \mathrm{~m}$. N.descruzados, X 35 .

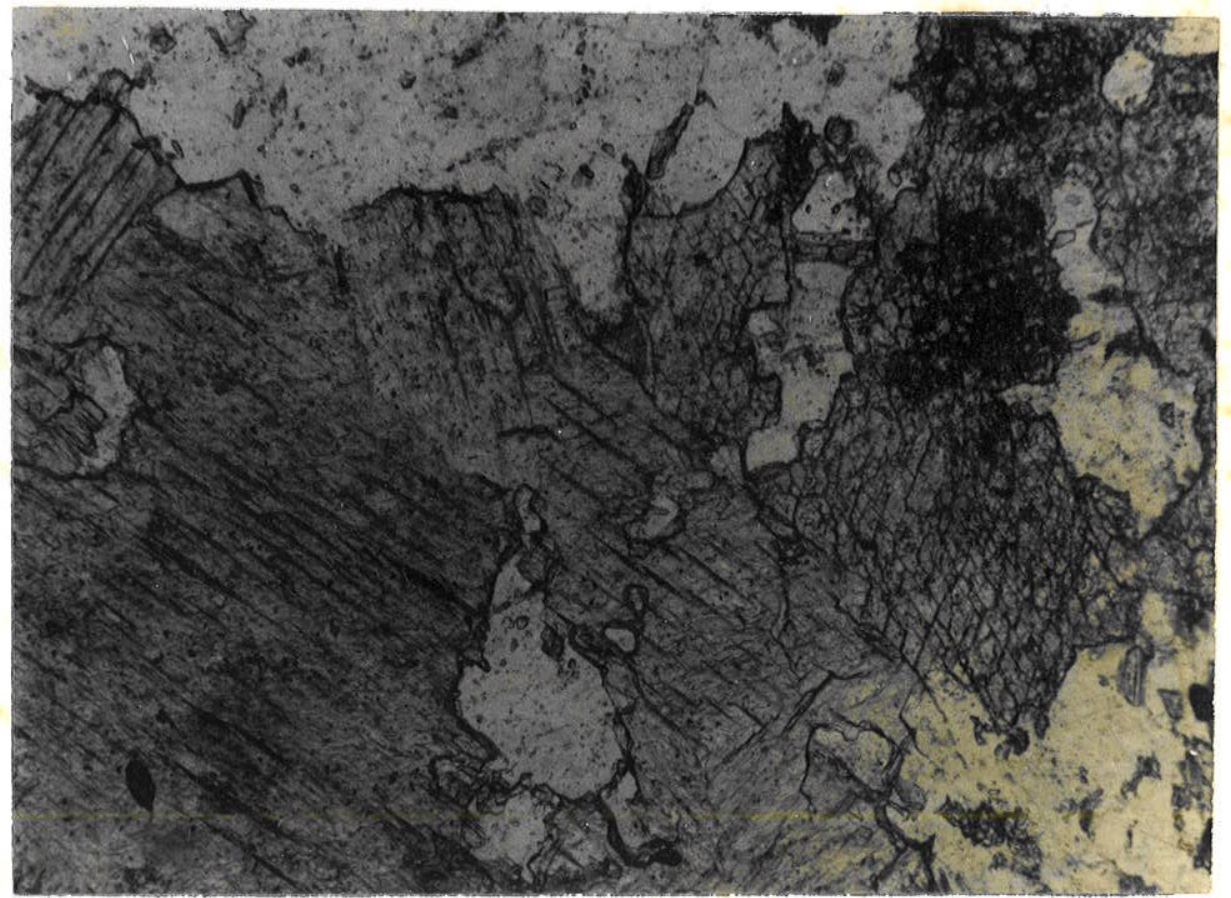

Foto 2-Calco xisto. Associação de microclínio,calcita,tremolita e salita.Rocha de textura granoblástica e nematoblástica com clinopiroxênio parcialmen te tremolitizado ao lado de calcita e microclínio.Amostra B5-10(507) 109,13 $-109,16$. N.descruzados. X 88 . 


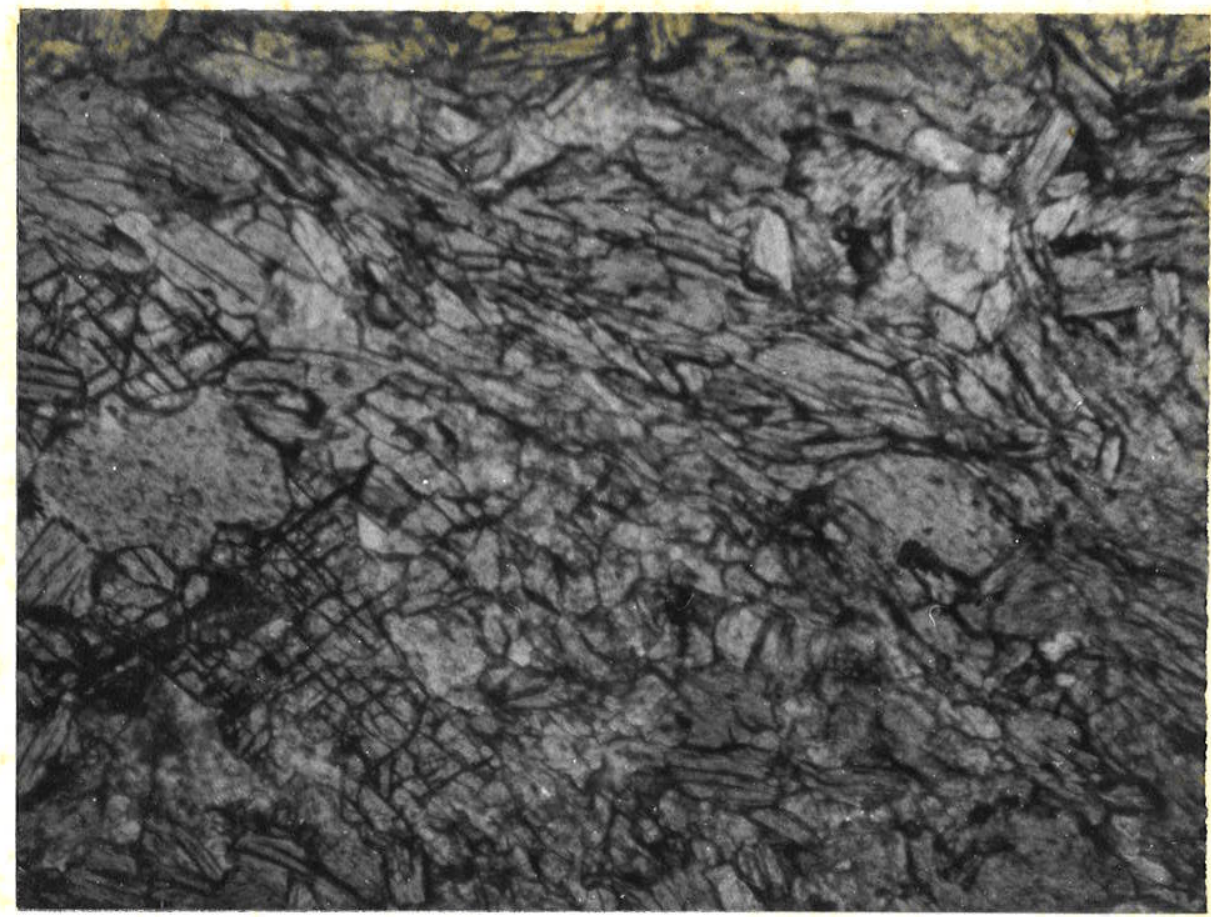

FOTO 3-Mármore calcossilicático. Rocha de textura lepidoblástica constituída por salita, flogopita orientada e carbonatos (Mn calcita e às vezes dolomi ta). Amostra B5-10-108,90m. N. descruzados, X 35 .

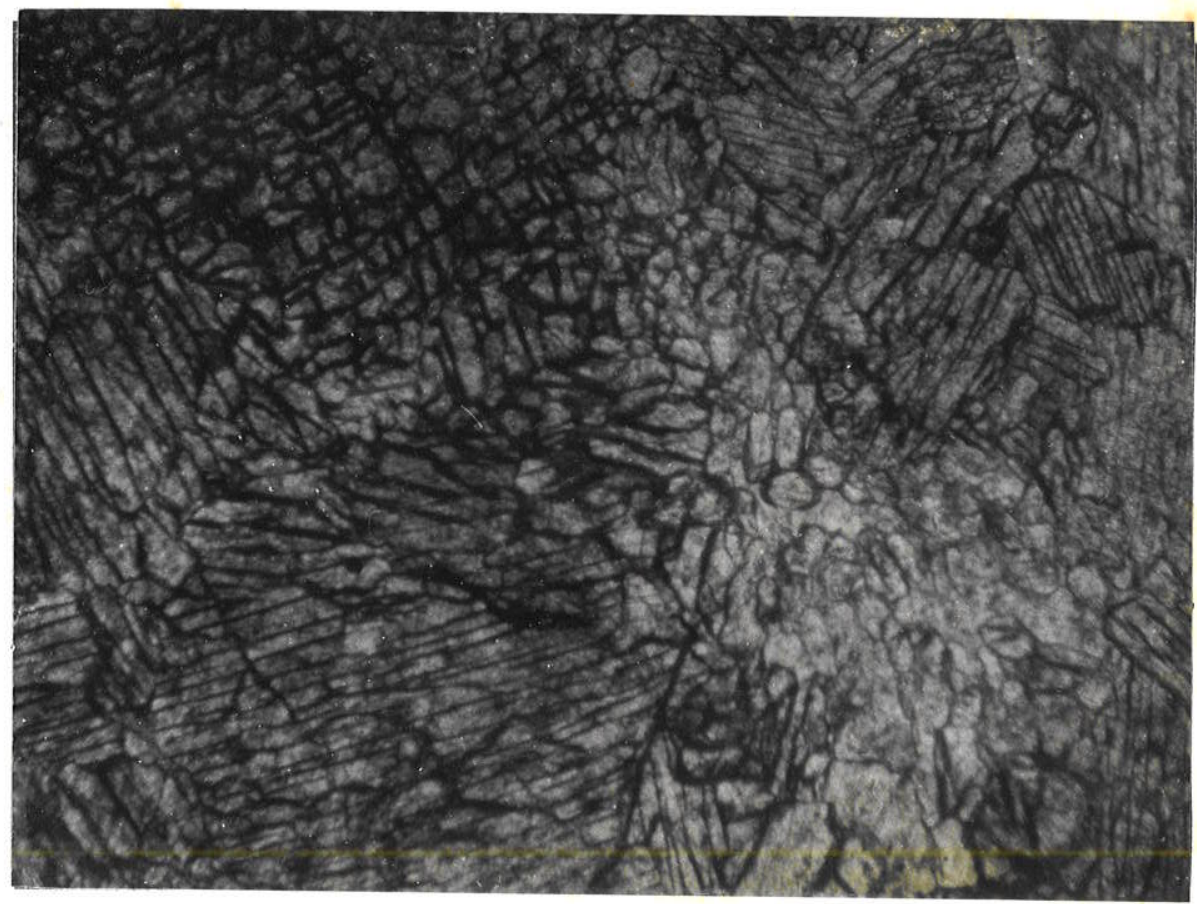

FOTO 4- Mármore calcossilicático. Leitos mais grosseiros com textura blástica, onde ocorre clinopiroxênio (salita) associado a carbonato e grano molita. Amostra B5-10-108,90m. N. descruzados, X 35. 


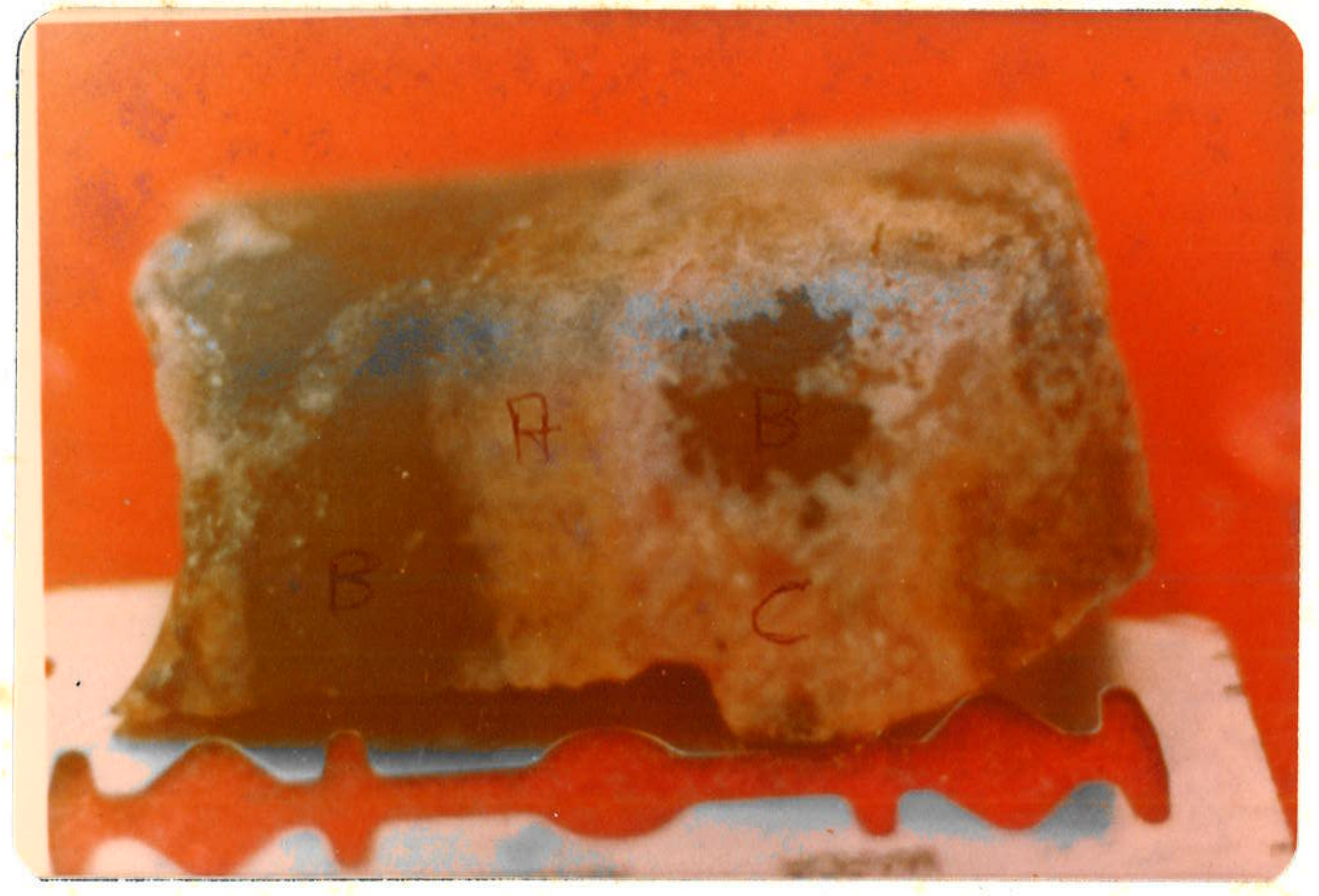

FOTO 5-Protominério carbonático de manganês-Braunita Mármore. Partes pretas são constituỉdas por braunita (e hausmanita), com aspecto de fragmentos

(brechas) e manganofilita. Zonas de coloração parda são formadas por inter crescimentos de Mn-calcita e flogopita, contendo também algum óxido de man ganês. Zonas de coloração rosada são constituỉdas por rodonita bem cristáa lizada, com cristais de até $7 \mathrm{~mm}$ com inclusões de carbonatos. Amostra B5-10 (501) $-92,00-92,09 \mathrm{~m}$.

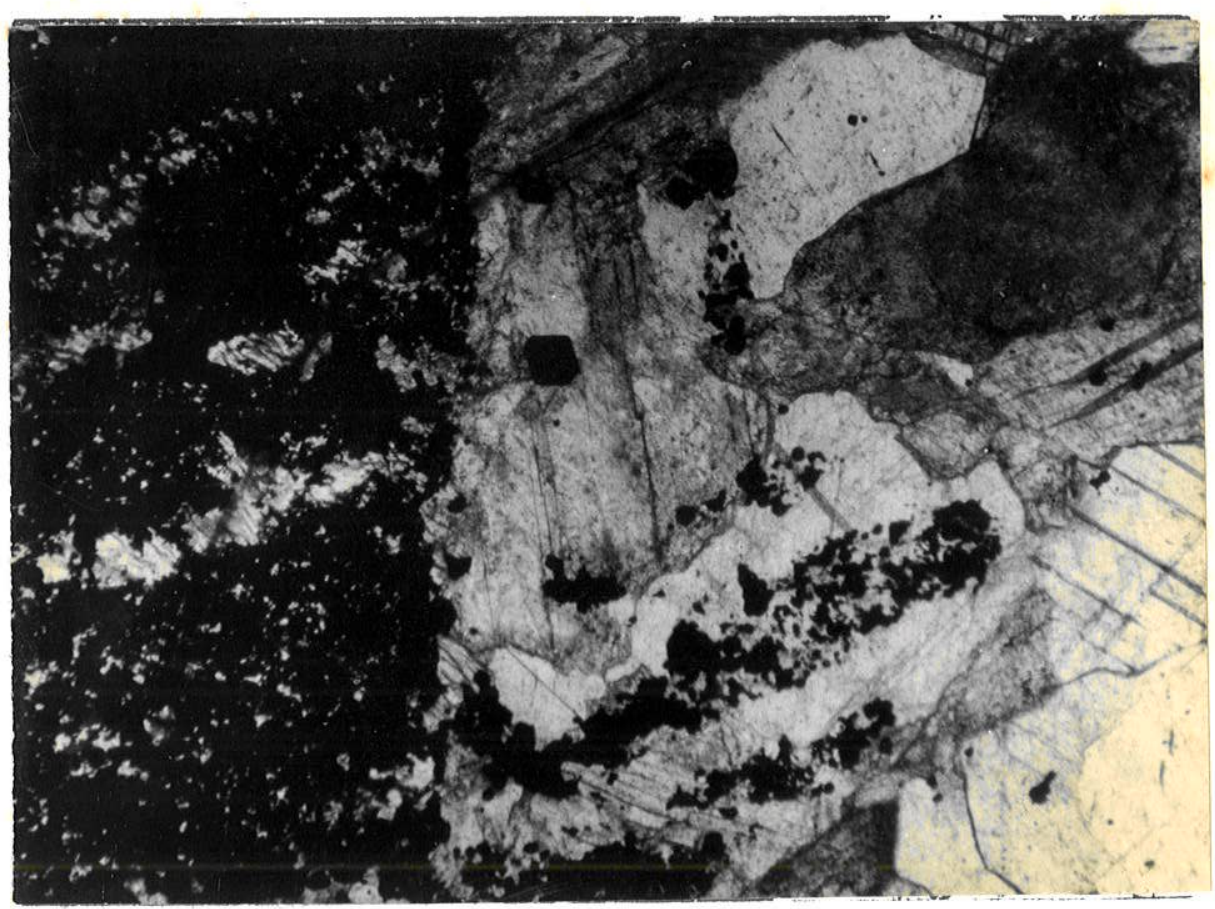

FOTO 6-Protominério de manganês-Braunita Mármore.Faixa de braunita com inclu sões de carbonato em contato discordante com mármore calcítico (às vezes do lomítico) de textura granoblástica. O mármore é constituído por calcita (do1omita) e piroxenóide (rodonita). Amostra B5-10-95,5m.N.descruzados, X 35 . 


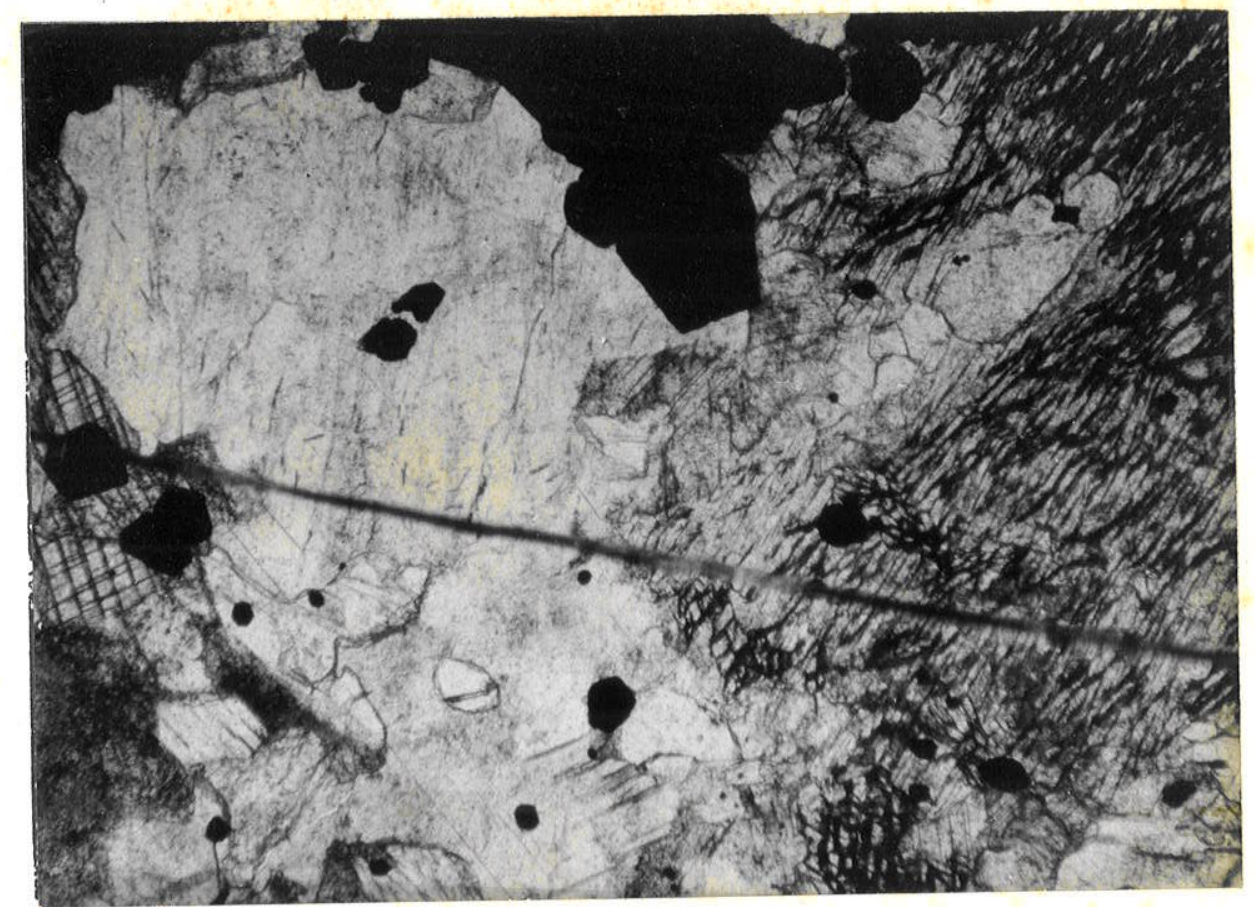

FOTO 7-Protominério carbonático de manganês. Braunita mármore. Märmores (cal cíticos e às vezes dolomíticos) com flogopita e clinoanfibólio (tremolita). Clinoanfibólios crescendo dentro dos carbonatos. À direita - carbonatos e clinoanfibólios. Ā esquerda - märmore. Em cima - braunita (e hausmanita) re cristalizada. Amostra B5-10-95,5m. N. descruzados, X 35 .

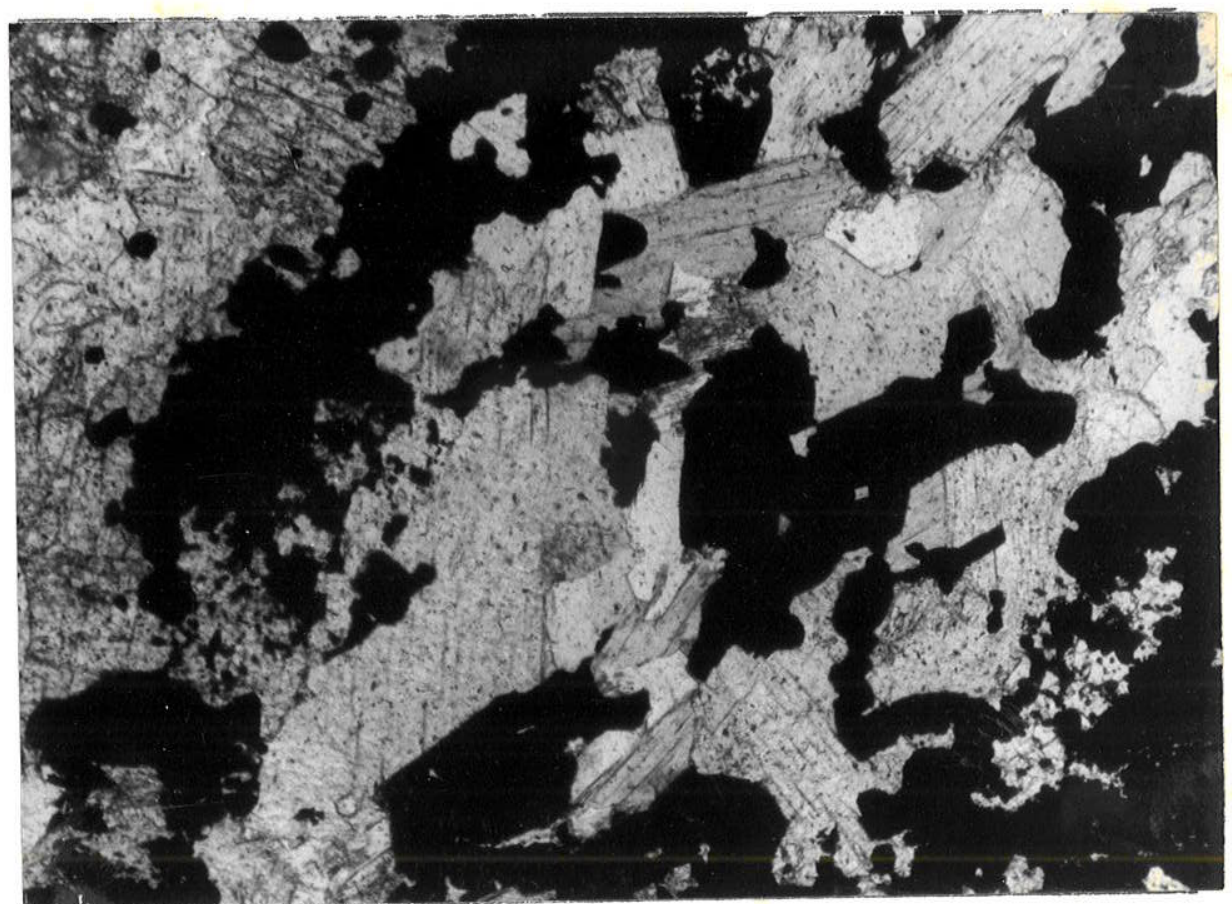

FOTO 8-Protominério carbonático de manganês. Braunita Mārmore. Associação de carbonato (Mn-calcita) braunita e hausmanita, flogopita, rodonita e plagioclásio. Braunita intercrescida granoblasticamente com os demais minerais. Amostra B5-10-90,7m. N. descruzados, X 88 . 


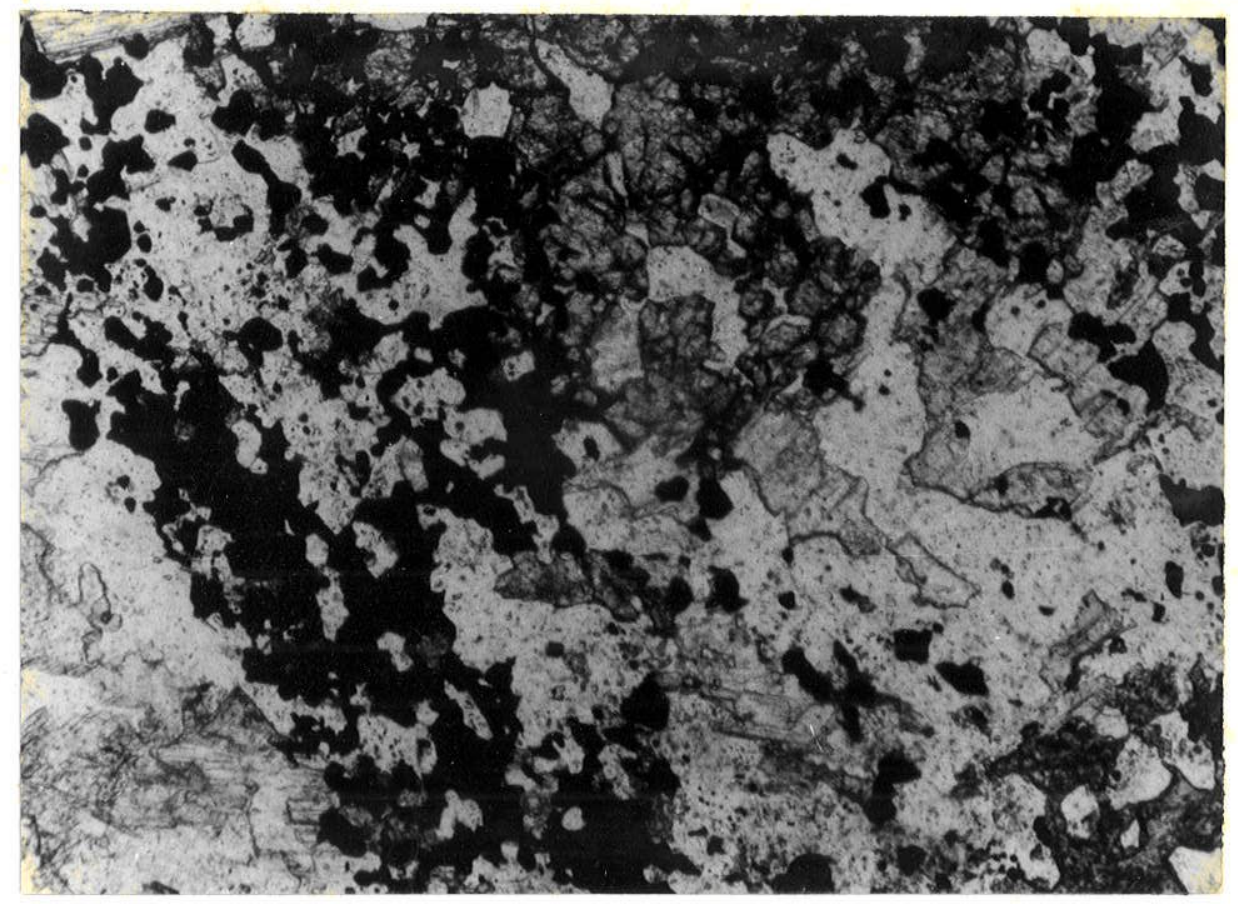

$-46^{\circ}-$

FOTO 9- Protominērio de manganês. Braunita mármore. Associação de granada, clinoanfibólio, plagioclásio, feldspato potássico, quartzo, rodonita e brau nita (disseminada e disposta em 1eitos). Amostra B5-10-91,1m. N. descruzados, $\mathrm{X} 88$.

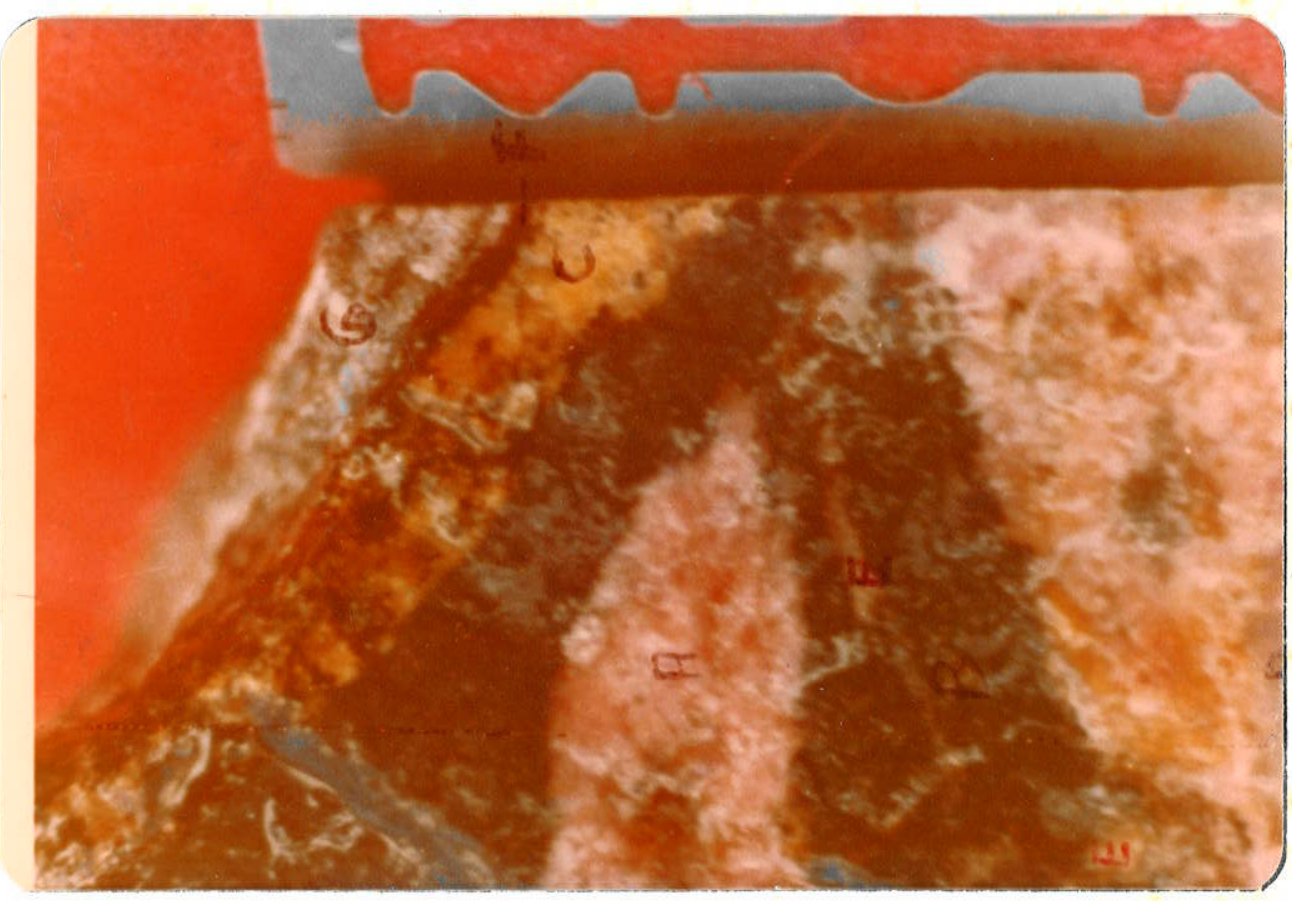

FOTO 10-Protominério de manganês. Braunita mármore. Partes de coloração pre ta: braunita e hausmanita intercrescidas com manganofilita e carbonato fino. Essas zonas possuem manchas claras formadas por clinopiroxênios, feldspato, clinoanfibólio e carbonatos. Zonas róseas são constituídas por rodonitas (cristais de 1 a $4 \mathrm{~mm}$ ). No contato entre rodonita e opacos temos clinopiroxê nios finos. Partes de coloração parda constituỉdas por clinopiroxênios $f \bar{i}$ nos $(0,2-0,4 \mathrm{~mm})$. Faixa de coloração cinza clara, situada à esquerda da foto, é formada por granada, flogopita e quartzo. Faixa de coloração branca rosa da situada à direita da foto é constituída por quartzo, feldspato e barita. Amostra B5-10(504)-92,10-92,16m. 


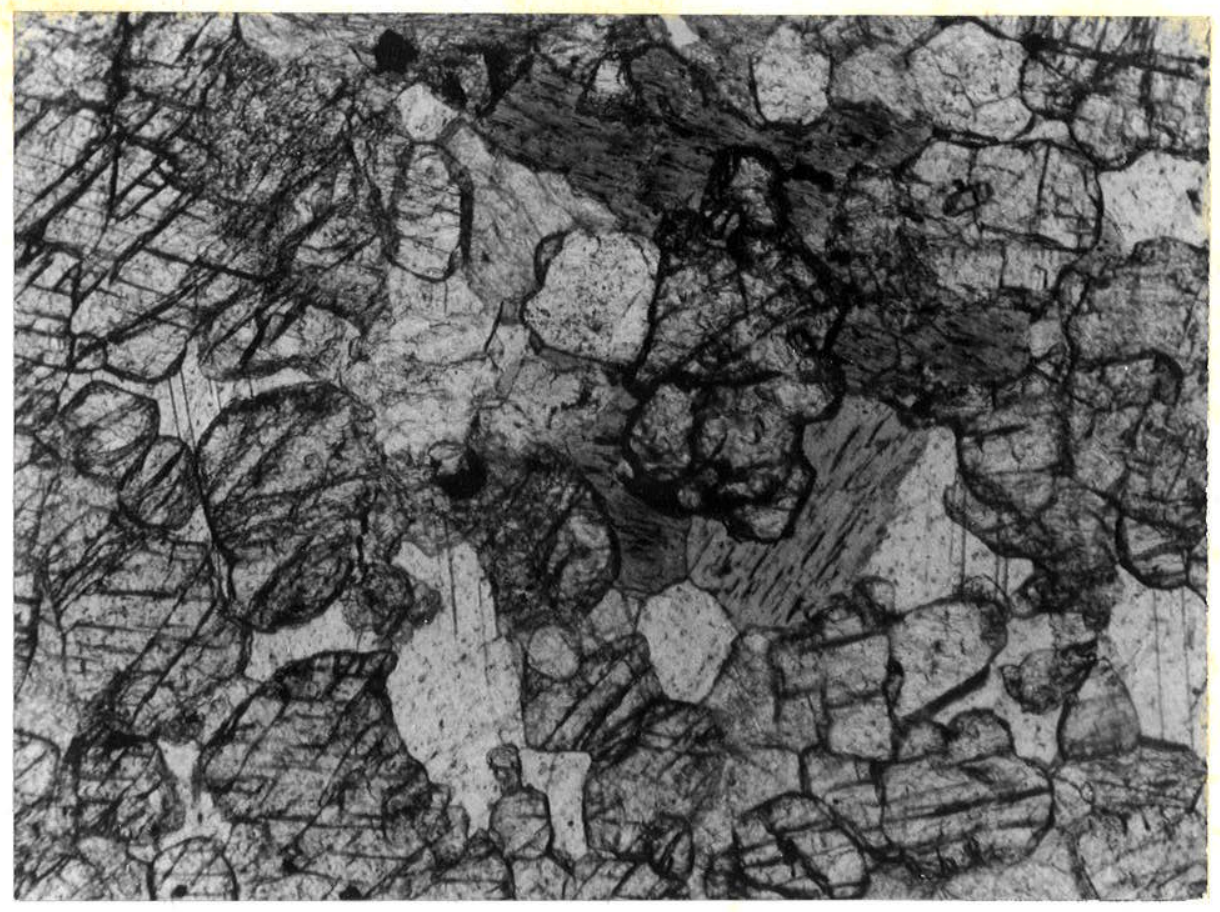

FOTO 11-Rocha calcossilicática com textura granoblástica. Associação de gra nada, flogopita, calcita, tremolita e diopsídio tendo como acessório apatita. Amostra B5-10-87,9m. N. descruzados, X 88 .

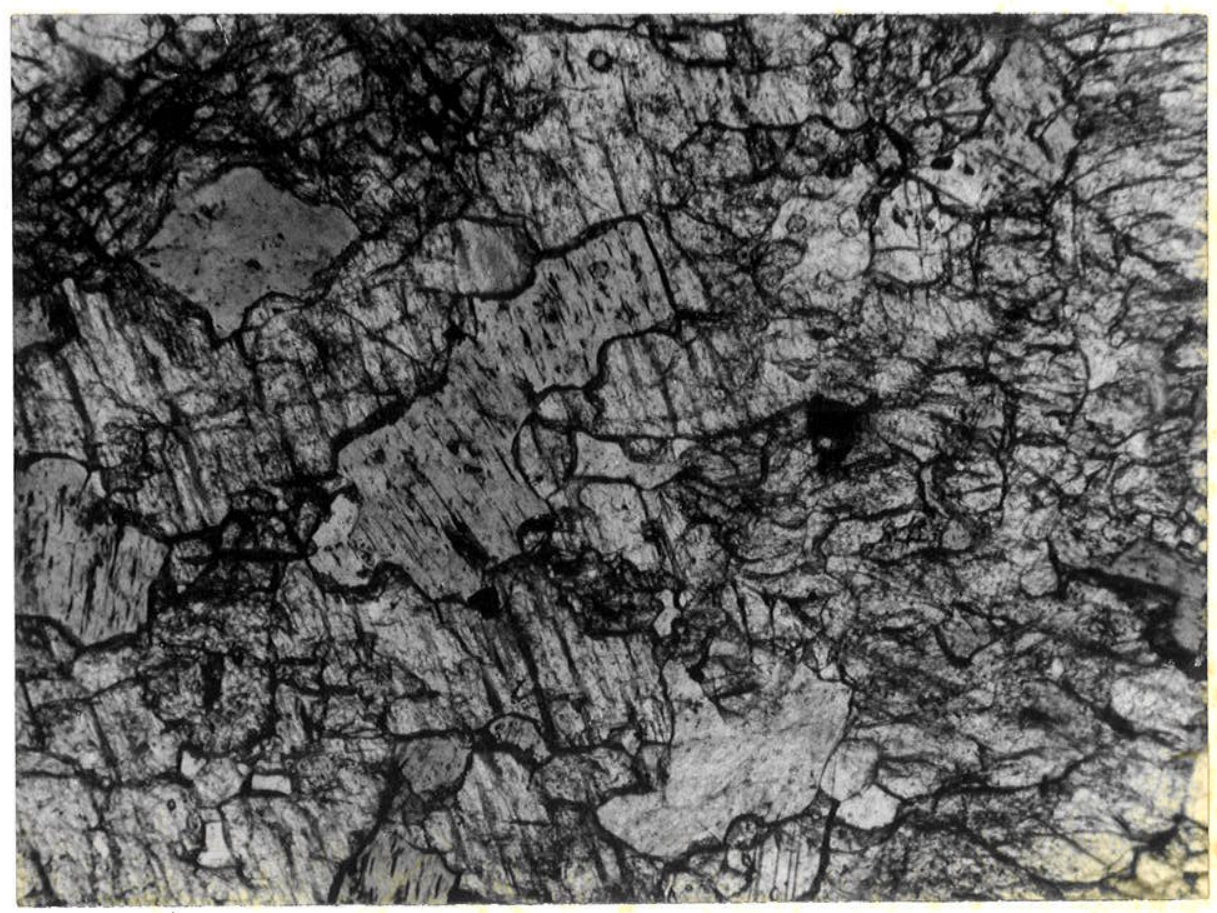

FOTO 12- Rocha calcossilicática. Associação de calcita, tremolita,diopsỉdio, granada e flogopita. Textura granoblástica. Amostra B5-10-87,9m. N.descruzados, X 88 . 


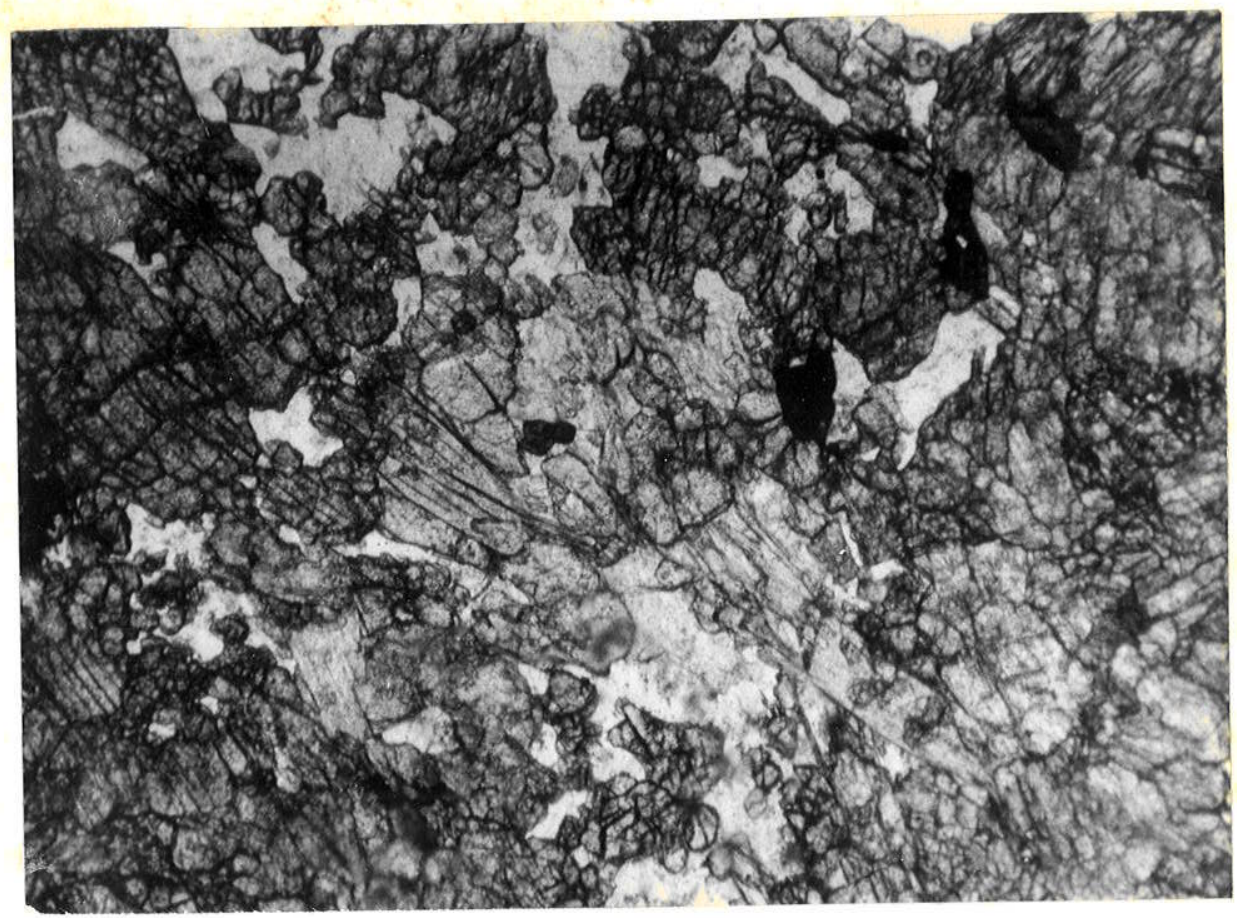

$-48-$.

FOTO 13-Rocha calcossilicática. Rocha de textura granoblástica com carbonato (calcita), clinopiroxênio (hedembergita) e microclínio, tendo como acessó rio, titanita. Amostra B5-10-69,6m. N. descruzados, X 35 .

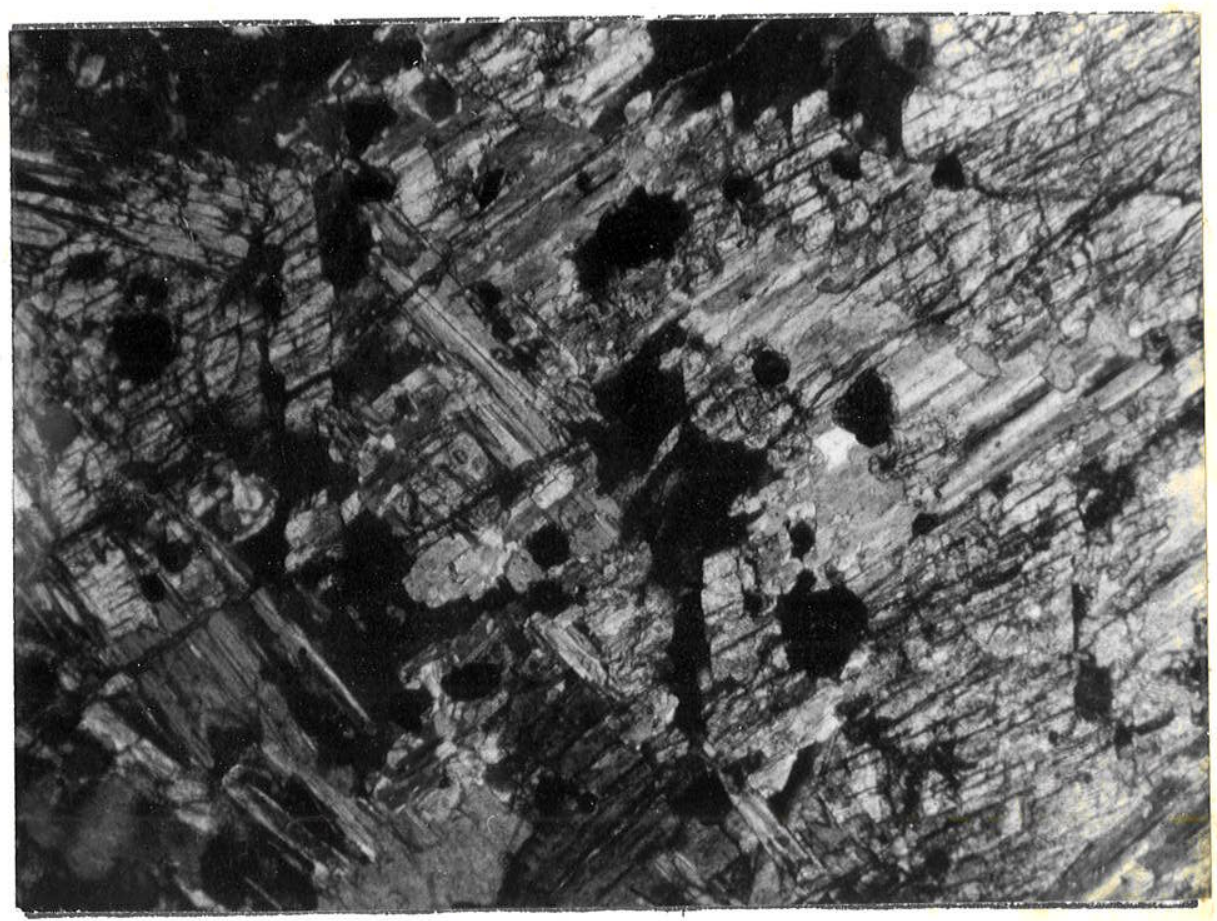

FOTO 14-Rocha calcossilicática de textura grano-nematoblástica com granadas (que se apresentam extintas), carbonato (calcita), hedembergita e clinoanfi bólio. Amostra B5-10-69,9m. N. cruzados, X 35 . 


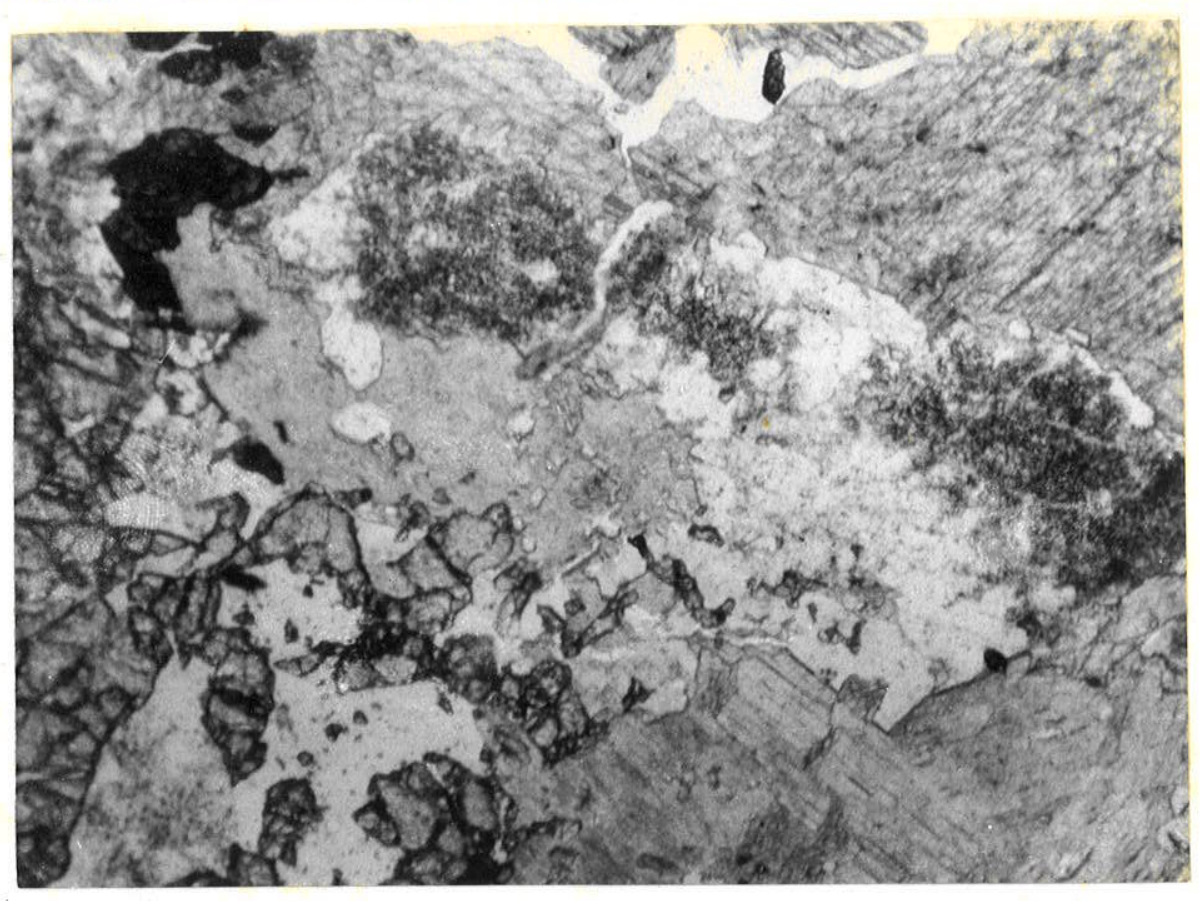

FOTO 15-Rocha calcossilicática de textura granoblästica. Associação de carbo nato (calcita), plagioclásio, granada e tremolita, tendo como acessório có mum a titanita. Amostra B5-10-67,1m. N.descruzados, X 35 .

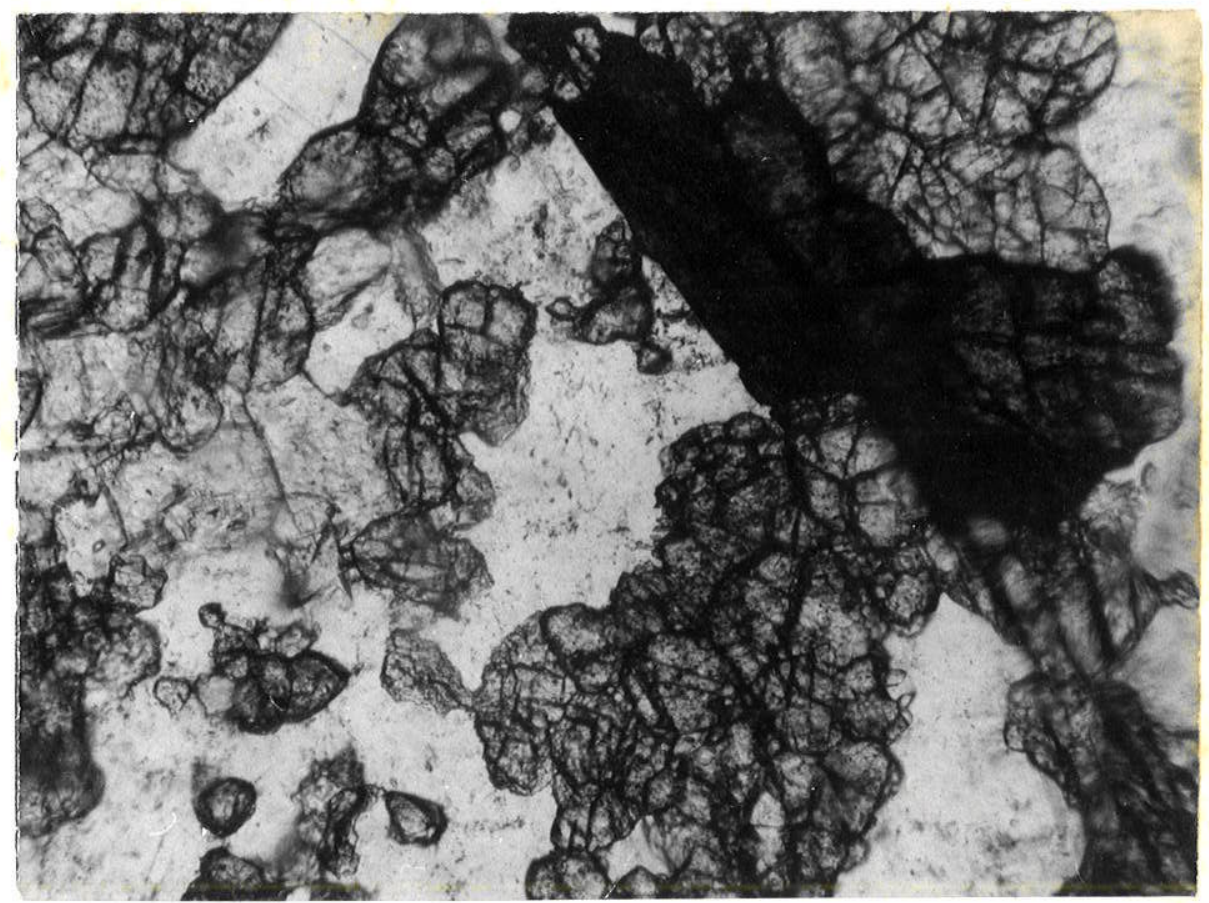

FOTO 16-Rocha calcossilicática. Textura granoblástica com porfiroblastos de clinopiroxênio. Associação de carbonato (calcita), hedembergita, microclỉnio e como acessório a titanita (macrocristal escuro). A hedembergita ocorre ora como cristais pequenos, ora como porfiroblastos. Amostra B5-10-69,6m. N. des cruzados, X 88 . 


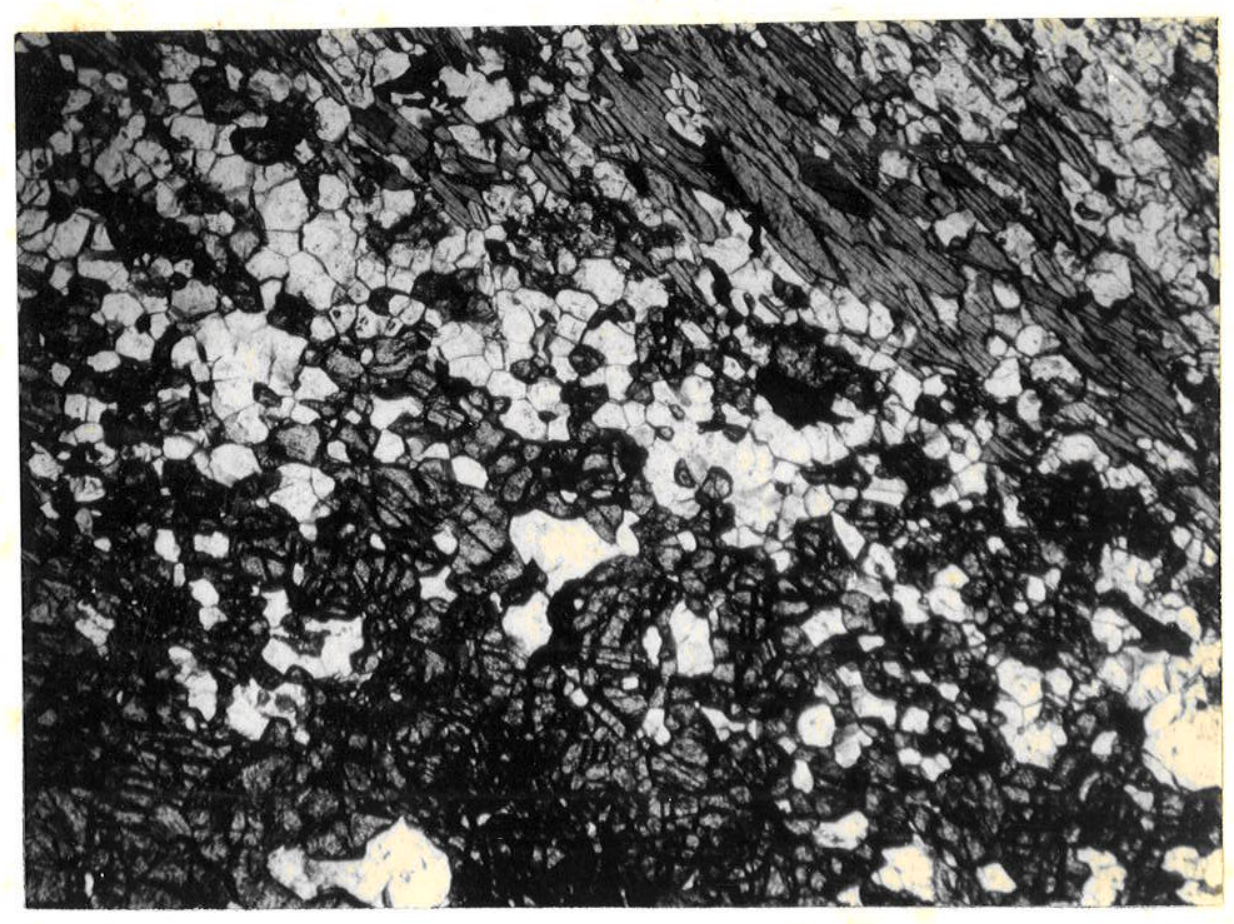

$-50 \div$

FOTO 17-Contato entre rocha xistosa e calcossilicática. A parte xistosa apre senta textura lepidoblästica e constitui-se essencialmente de biotita e mi croclínio. Subordinadamente ocorrem turmalina e quartzo. A parte calcossili cática contém grande quantidade de diopsídio ao lado de microclínio,granada, carbonato (calcita), quartzo e titanita, mostrando textura granoblástica. Amostra B5-10-62,3m. N. descruzados, X 35 .

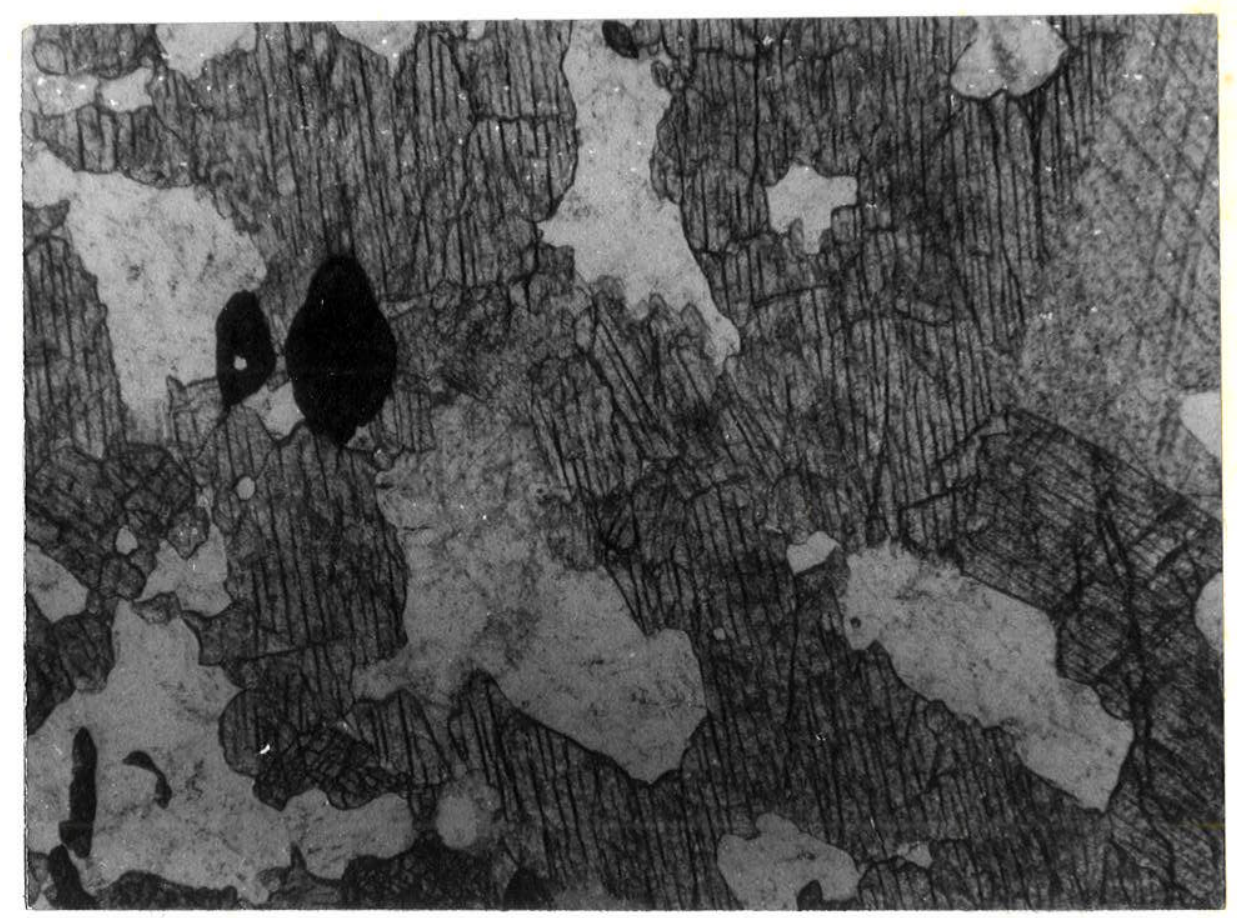

FOTO 18-Detalhe da parte calcossilicática da foto anterior. Associação, de diopsídio, microclínio, calcita e granada. Titanita ocorre como acessório. Amostra B5-10-62,3m. N. descruzados, X 35 . 


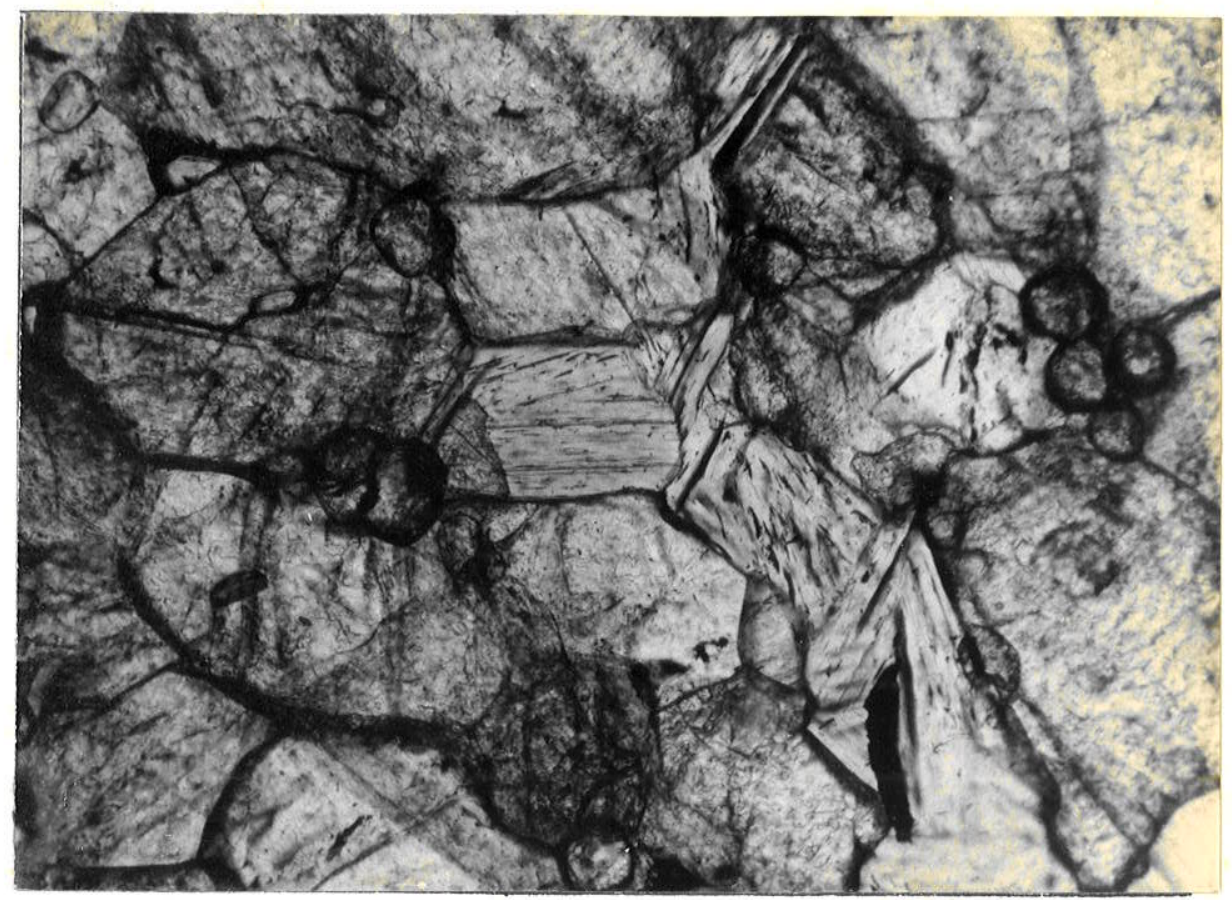

FOTO 19-Protominério de manganês. Mármore calcossilicático. Associação de car bonato (Mn-calcita-Mn-kutnahorita), granadas de diferentes tamanhos, mangano filita e pirofanita (como acessório). A manganofilita encontra-se tambēm in̄ cluỉda nos carbonatos. Textura granoblästica. Amostra B5-22-67,1m. N. descru zados, X 35 .

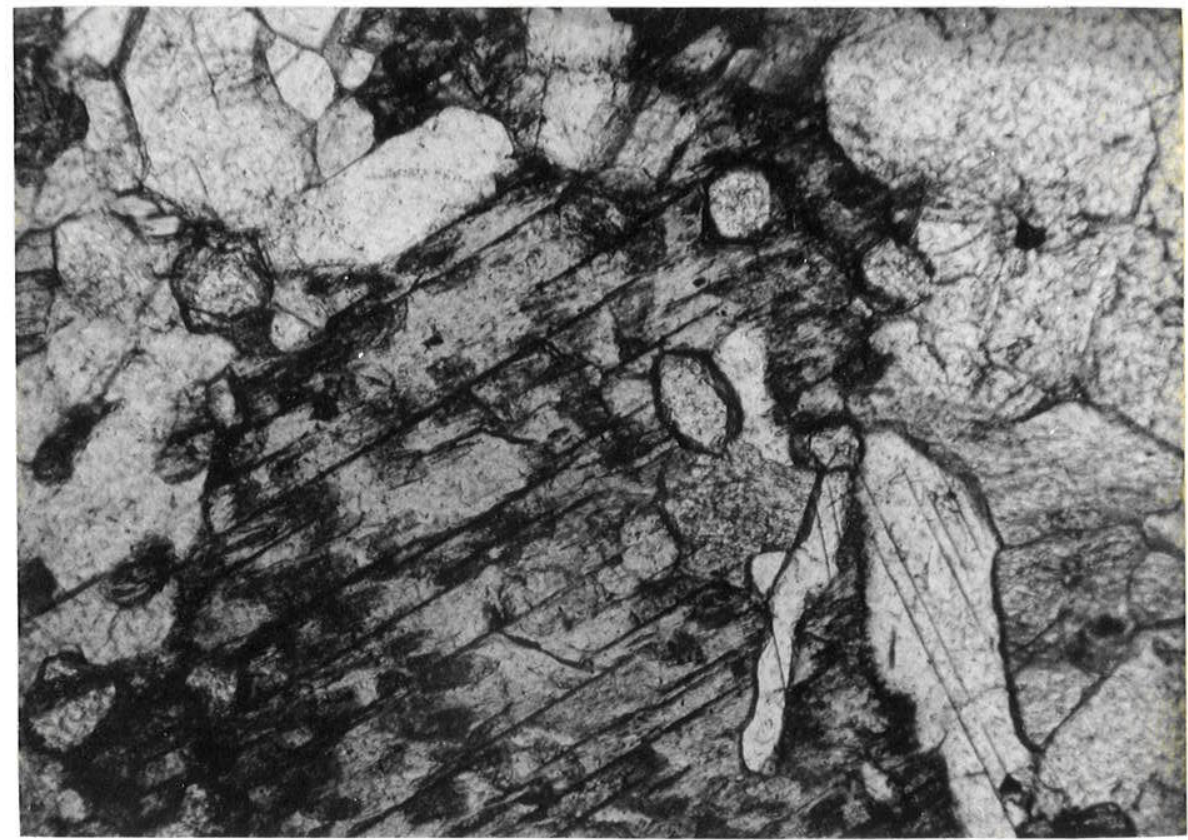

FOTO 20-Protominério de manganês. Märmore calcossilicático. Associação de car bonato (Mn-calcita-Mn-kutnahorita) com textura em mosáico, manganofilita li= geiramente serpentinizada e granada. A granada se encontra incluỉda no carbo nato e na manganofilit̄a, e apresenta granulação mais fina que os outros minerais. Acessório, apatita. Amostra B5-22-67,1m. N.descruzados, X 35. 


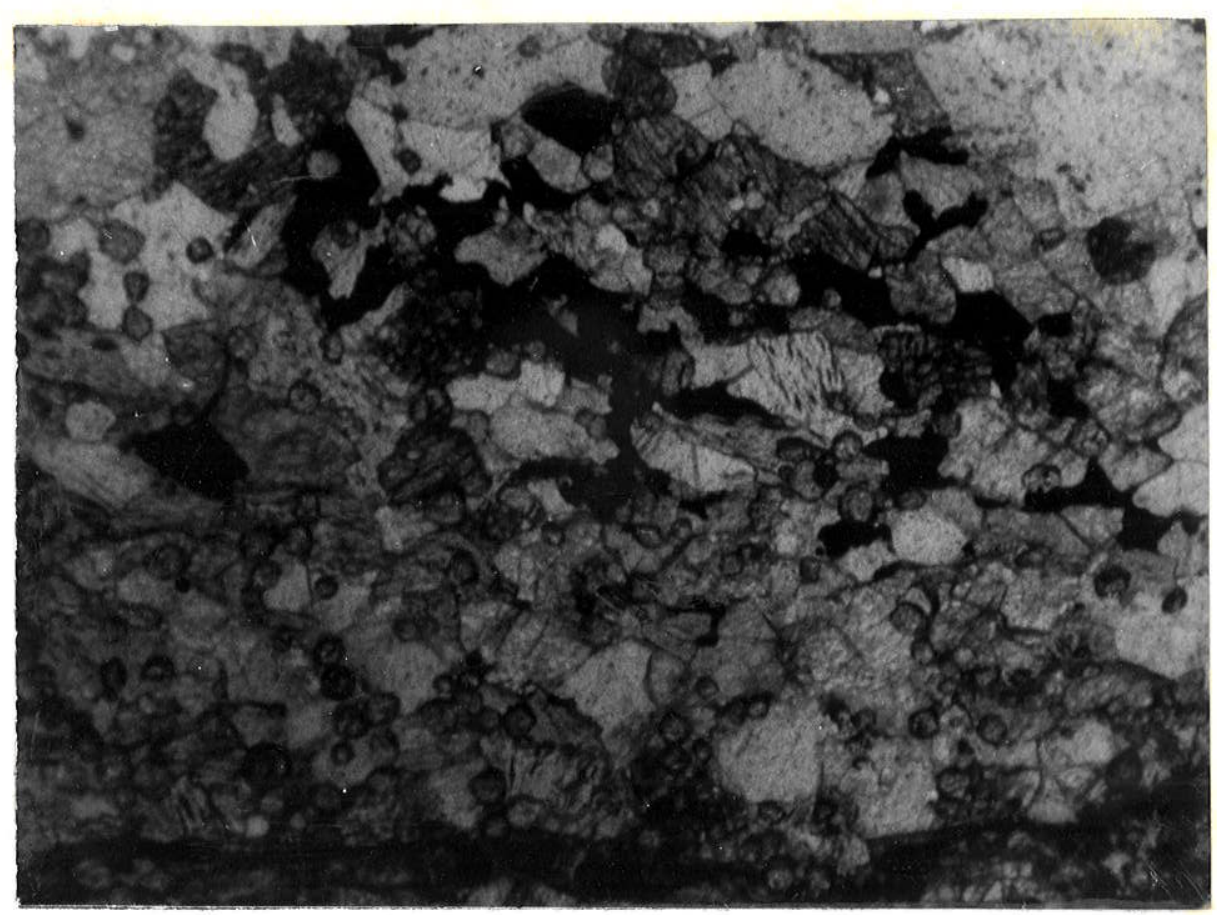

$-52-$

FOTO 21-Protominério de manganês. Märmore calcossilicático. Associação de car bonato (kutnahorita), granada, piroxmangita, manganofilita e opacos. Rochá de textura granoblástica e granulação relativamente uniforme a menos das gra nadas que são mais finas. Amostra B5-22-64,3m. N.descruzados, X 35.

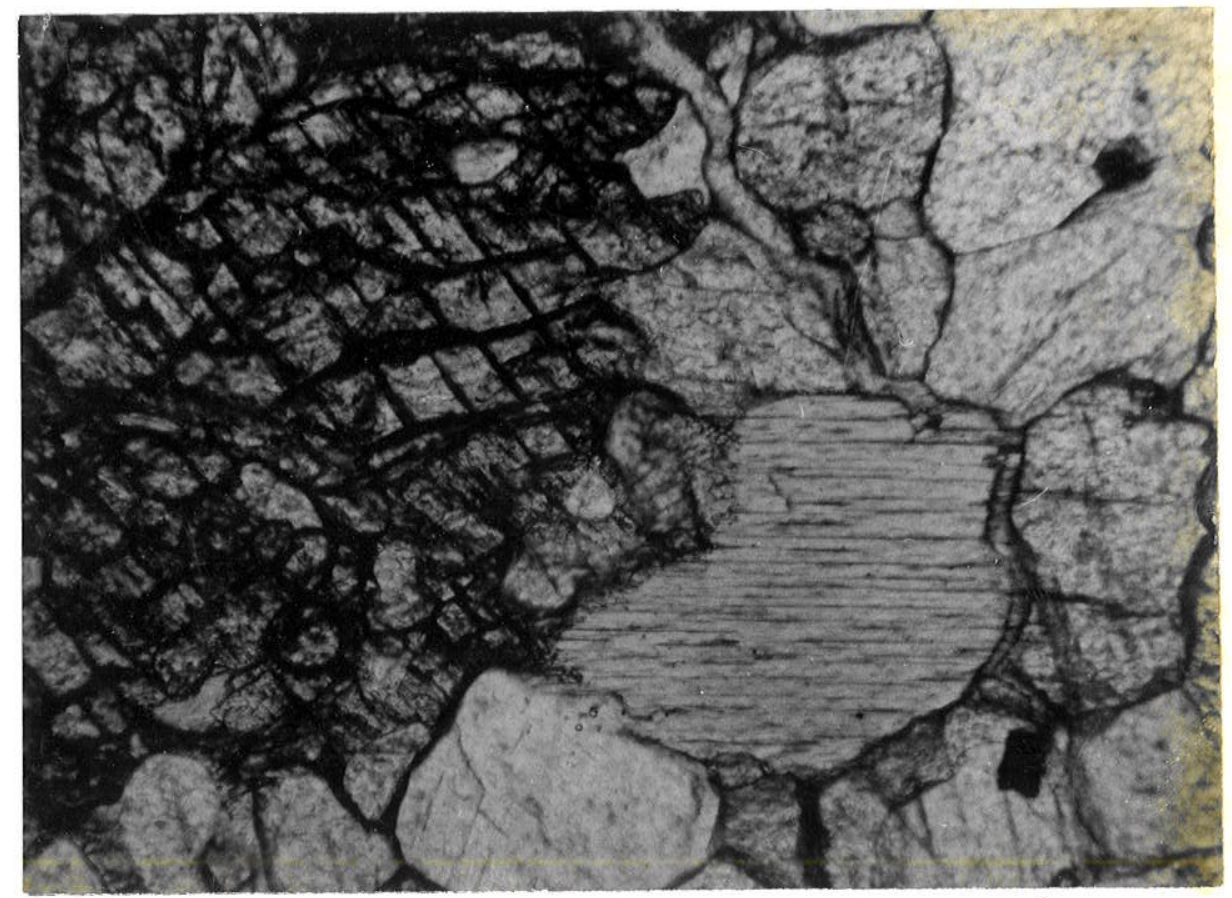

FOTO 22-Protominério de manganês. Piroxmangita mārmore. Mārmore constituído por carbonato (슬 tica com inclusões poiquilíticas de granada e carbonato, manganofilita e gra nadas de granulação fina. Veio de serpentinização corta o piroxenóide e os carbonatos. Amostra B5-14-72,0m. N. descruzados, X 35. 


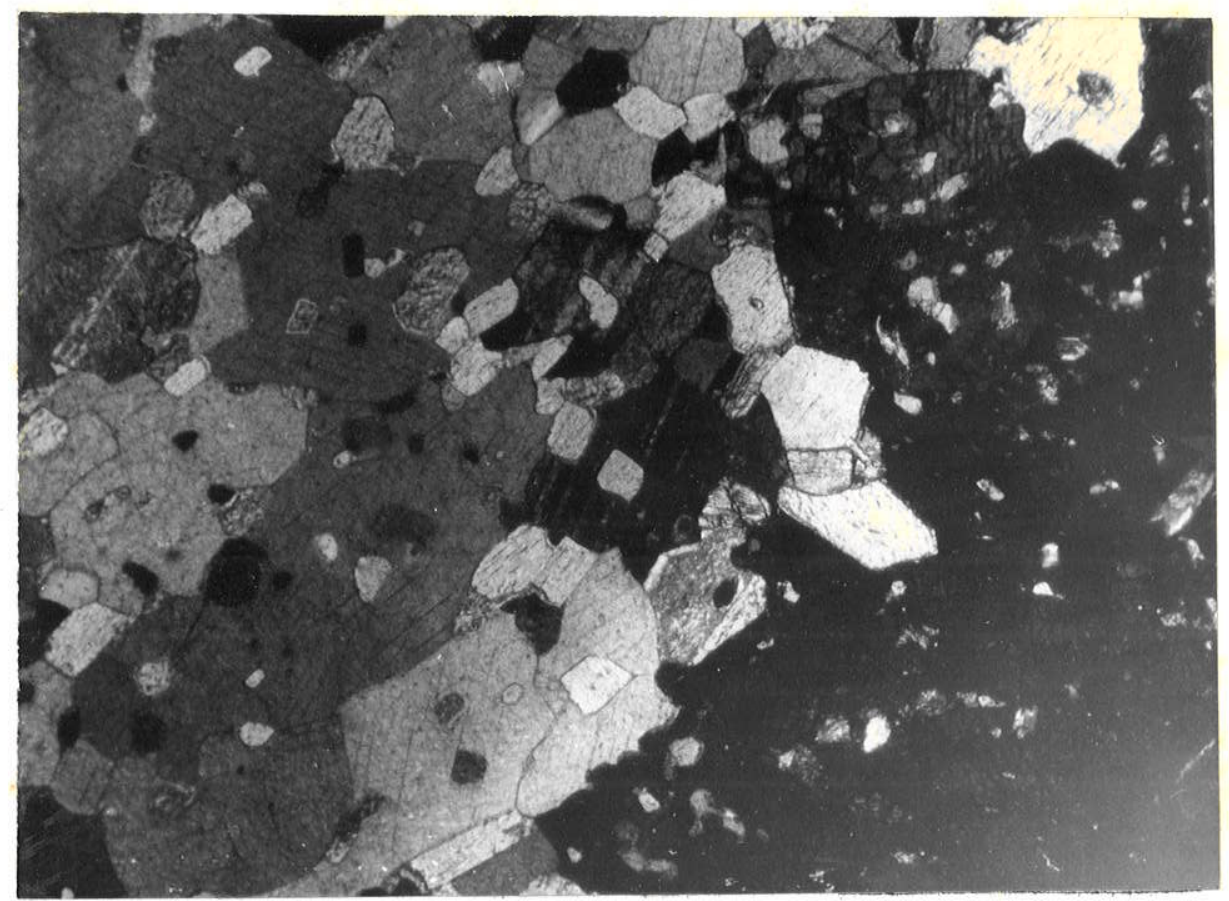

$-53-$

FOTO 23-Protominērio de manganês. Piroxmangita märmore. Mārmore constituí do por carbonato (kutnahorita), manganofilita orientada e granadas finas, com textura granoblástica orientada, em contato com porfiroblástos de pirox mangita com inclusões de carbonato e manganofilita. Amostra B5-14-67.8m. N.cruzados, X 35 .

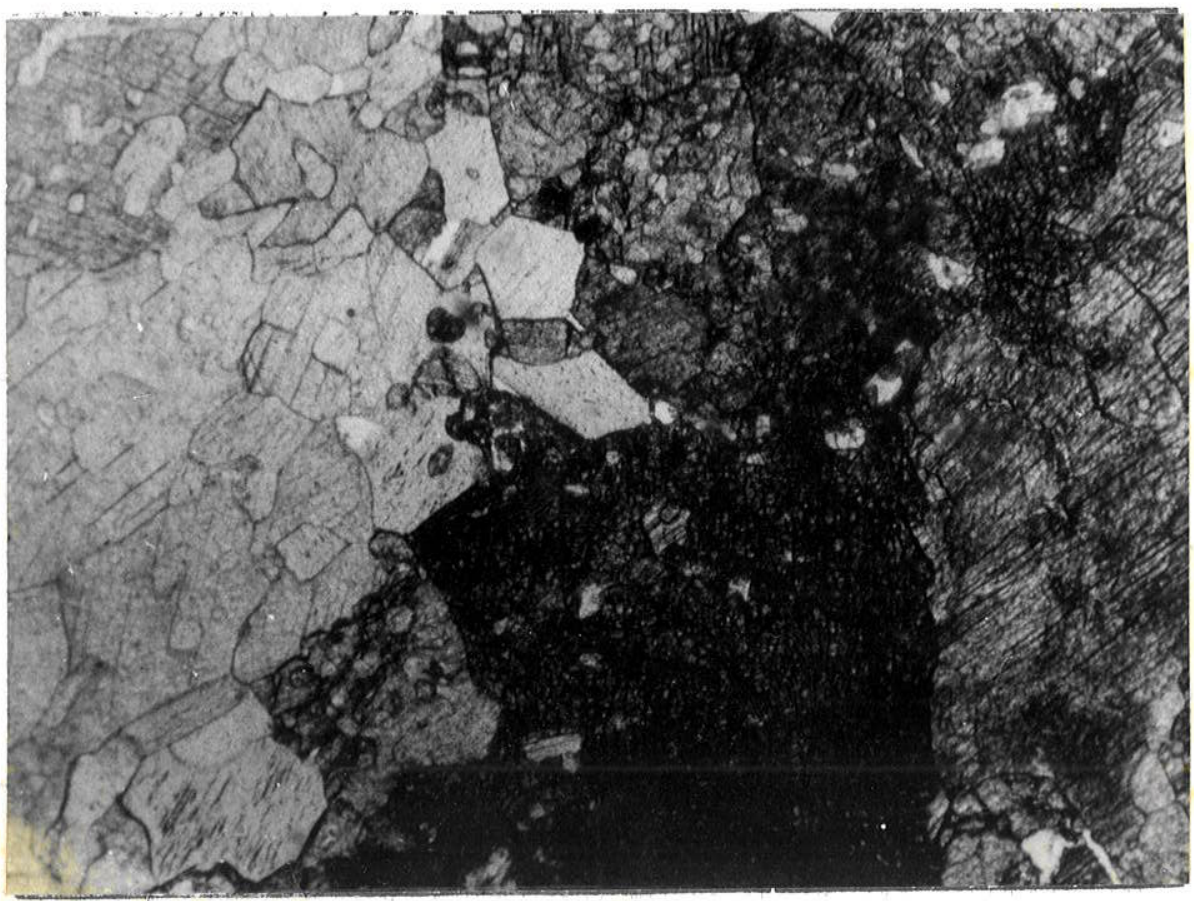

FOTO 24-Idem, foto anterior. Amostra B5-14-67,8m. N.descruzados, X 35 . 


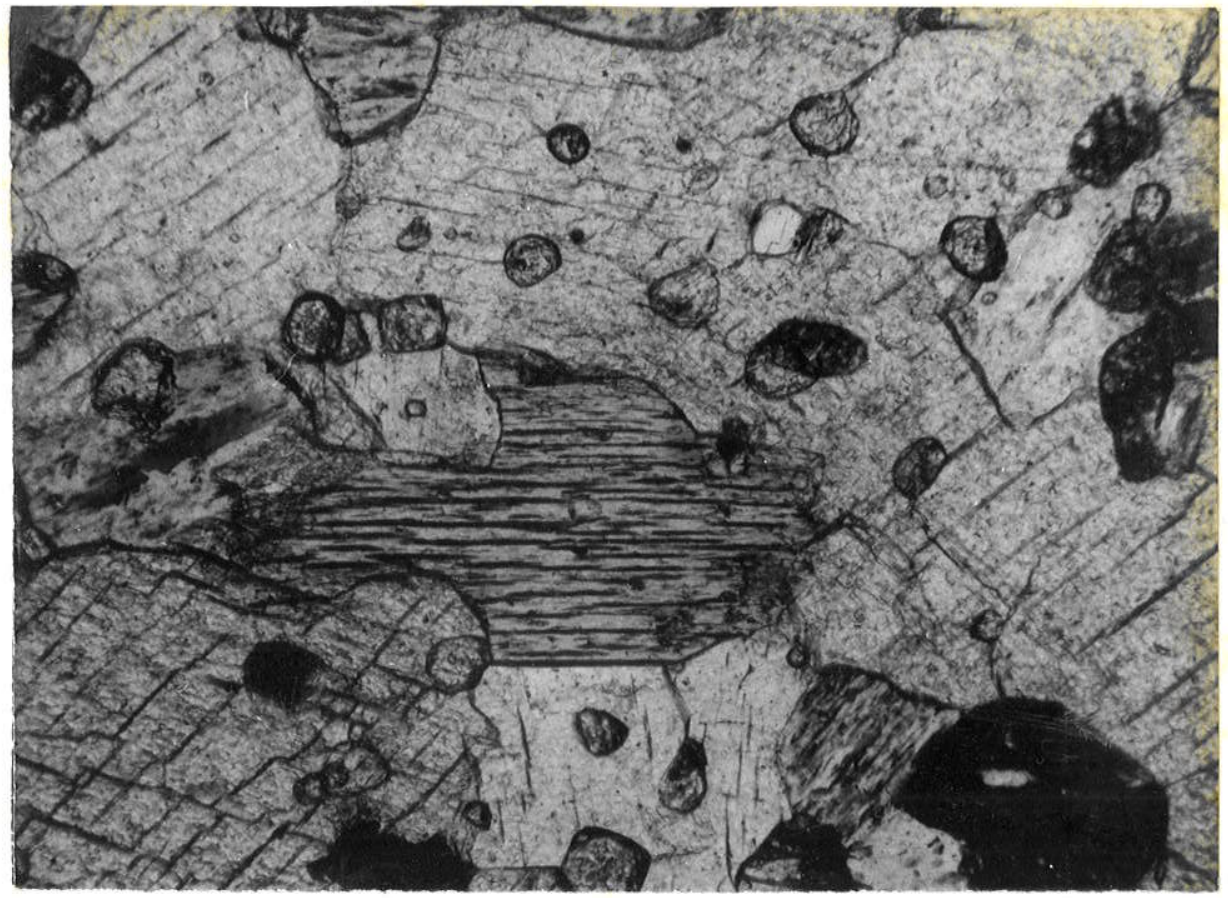

FOTO 25-Protominério de manganês. Mármore de textura granoblästica, constituí do por carbonato (kutnahorita), espessartita e manganofilita, tendo como acessório titanita e esfalerita. Faixas em que a manganofilita predomina so bre a piroxmangita. Amostra B5-14-69,9m. N. descruzados, X 35 .

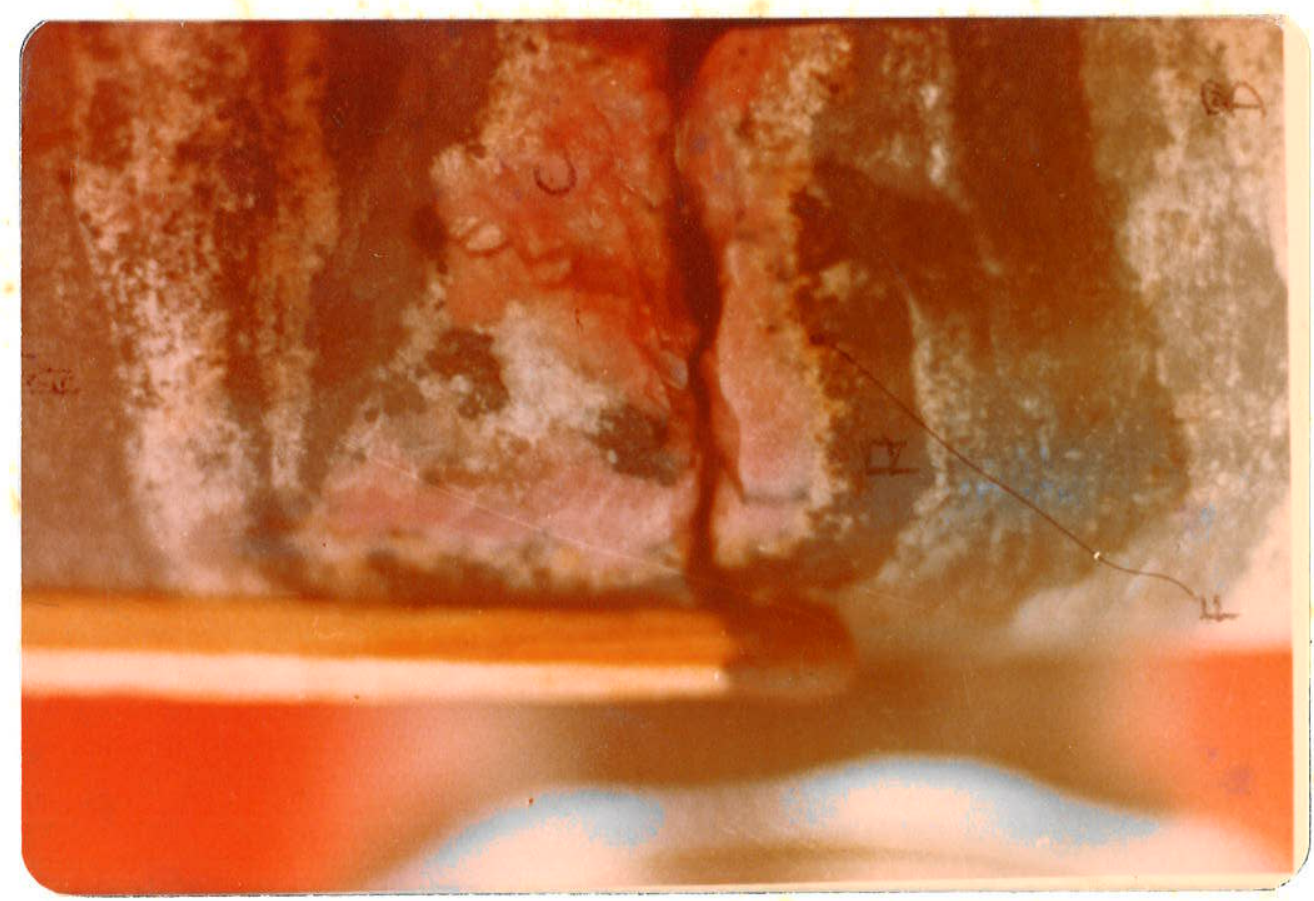

Fото 26-Protominério de manganês. Braunita märmore. Rocha com zoneamento de finido pela concentração de minerais diferentes. Zonas brancas e branco acinzentadas são constituídas por veios de quartzo grosseiro. Zonas pretas são formadas por braunita e hausmanita. Zonas róseas: cristais grandes de rodonita com algum quartzo e braunita em seu interior. A faixa cinza escura localizada no extremo esquerdo da foto é constituída por carbonato (ca1 cita, às vezes, dolomita) e clinopiroxênios. As zonas de separação entre os opacos e a rodonita é formada por Mn-flogopita, Mn-calcita, clinoanfibó lio e clinopiroxênio. Amostra B5-10 (506) 96,80-96,95m. 


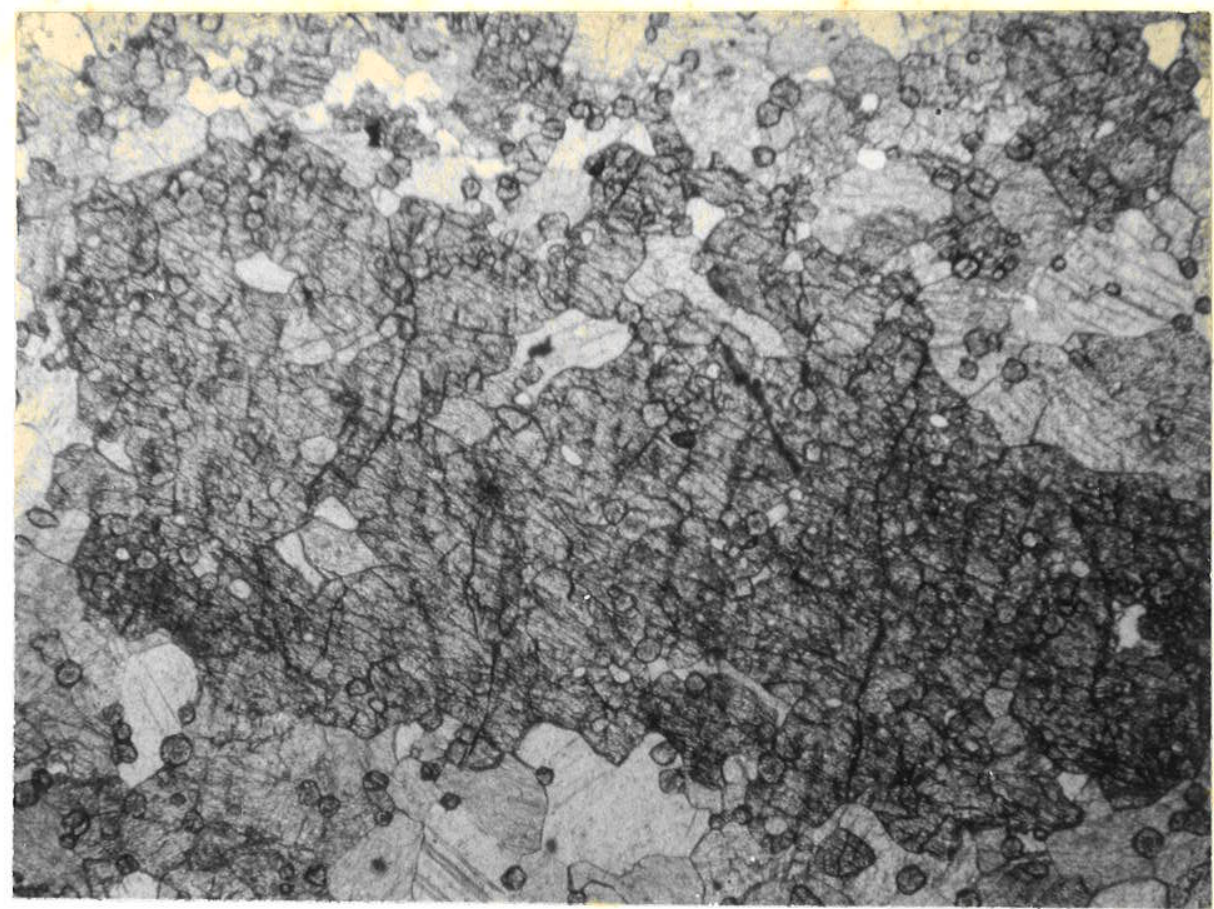

$-55^{-}$

FOTO 27a-Protominério de manganês. Tefroita märmore. Mārmore constituído por carbonato (kutnahorita-rodocrosita) com textura em mosáico, incluindo grana das finas, onde a tefroita aparece como porfiroblasto com inclusões poiqui líticas de carbonato e granada. Amostra B5-14-78,8m. N.descruzados, X 35 .

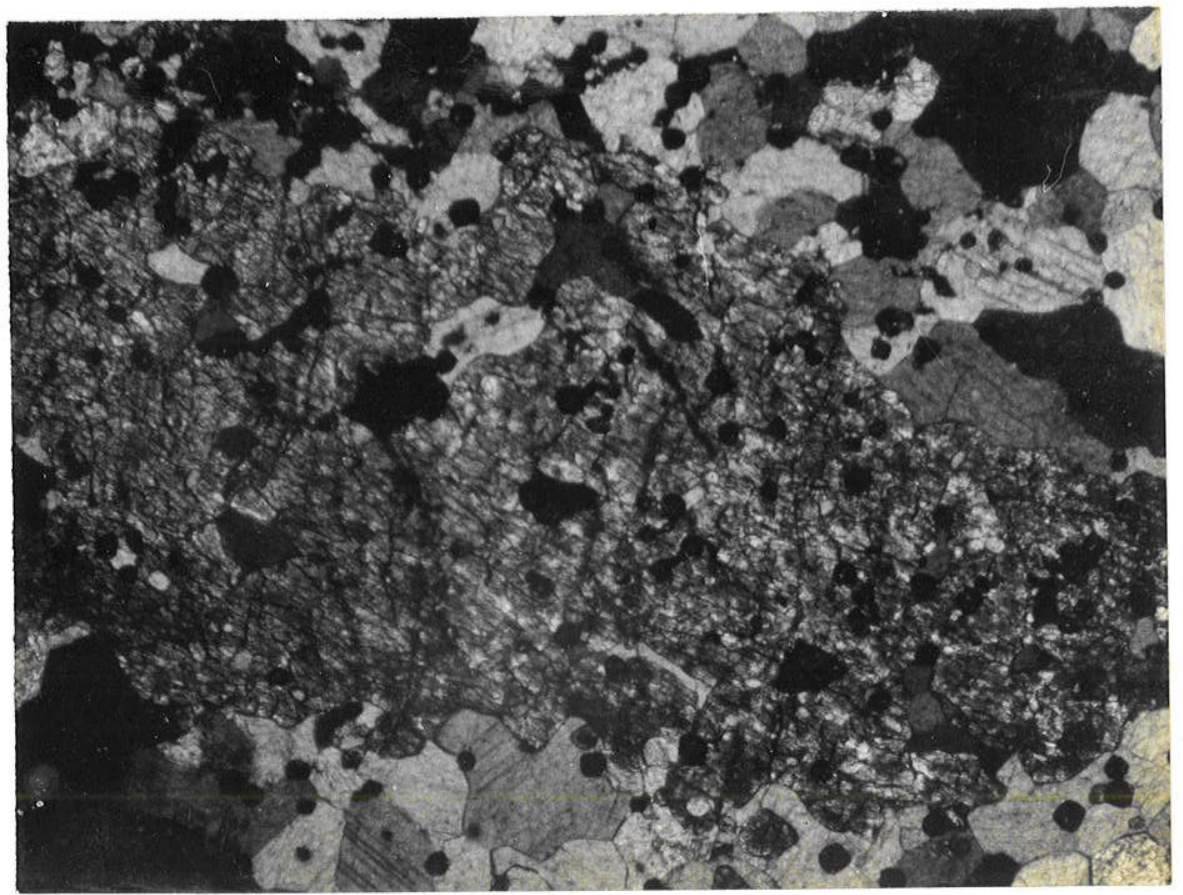

FOTO 27b-Idem, foto anterior. Amostra B5-14-78,8m. N. cruzados, X 35. 


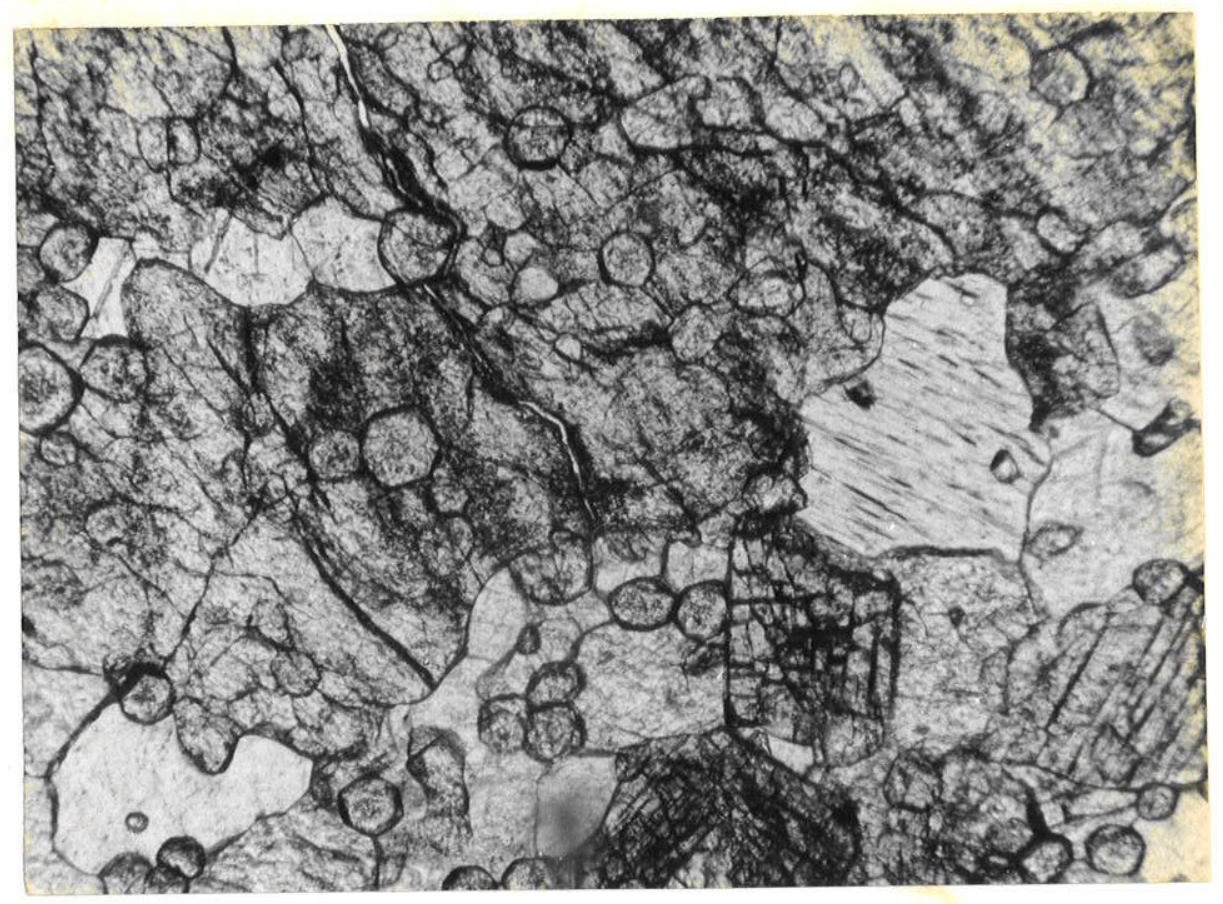

FOTO 28-Protominērio de manganês. Tefroita märmore. Olivina porfiroblästica com inclusões poiquilíticas de carbonato e granada fina, associada a car bonato (kutnahorita-rodocrosita), piroxmangita, granada e manganofilita. $\bar{A}$ granada possui granulação mais fina que os demais minerais. Amostra B5-14$-78,8 \mathrm{~m}$. N. descruzados, X 88 .

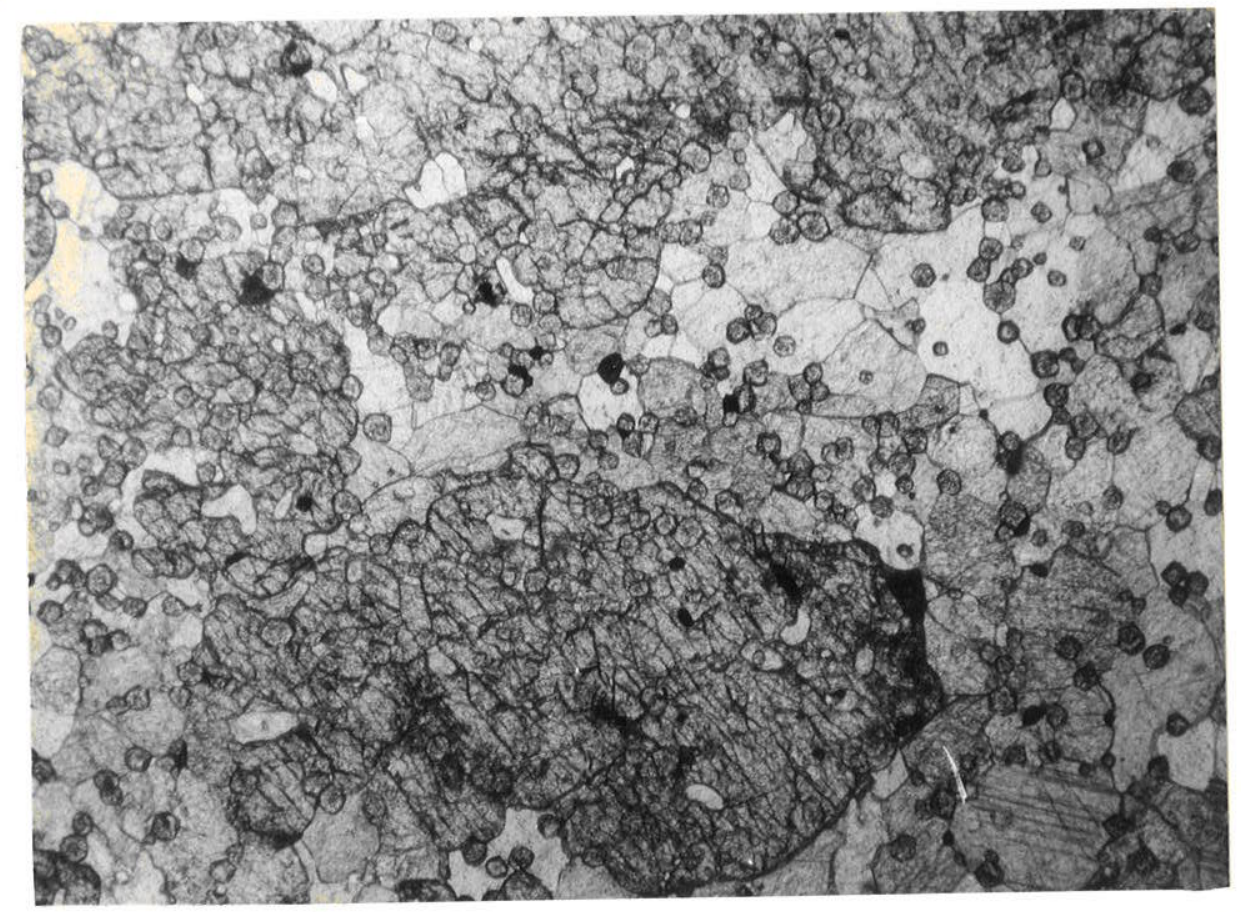

FOTO 29-Protominério de manganês. Tefroita märmore. Carbonato (kutnahorita-rodocrosita) com textura em mosáico englobando granadas finas. Destacam-se os porfiroblastos de tefroita com inclusões de carbonato e granada. Opacos também são observados. Amostra B5-14-78,8m. N.descruzados, X 35. 


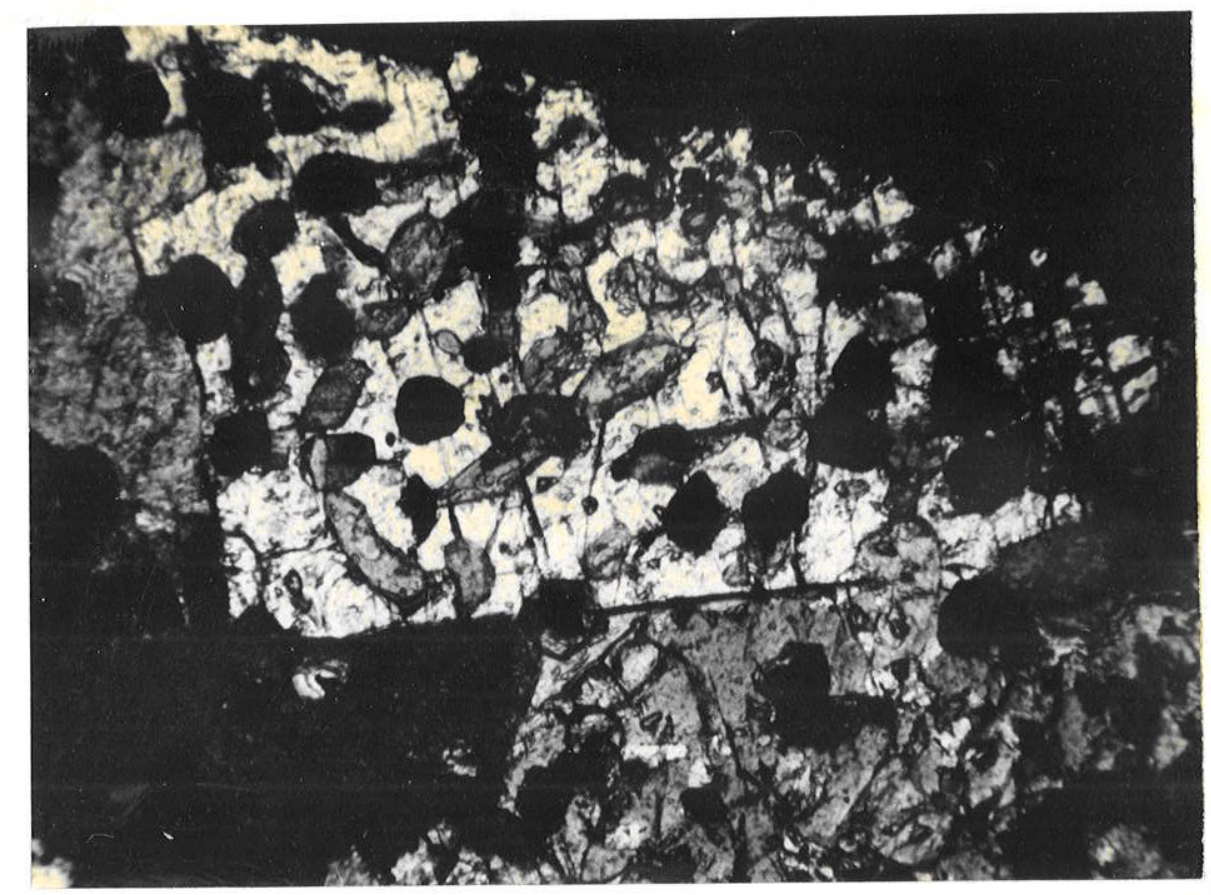

FOTO 30-Protominério de manganês. Piroxmangita märmore. Porfiroblasto de pi roxmangita, com inclusões poiquiliticas de carbonato e granada, em contato com olivina. A olivina (tefroita) também possui inclusões de carbonato e granada. Amostra B5-14-67,1m. N. cruzados, X 88 .

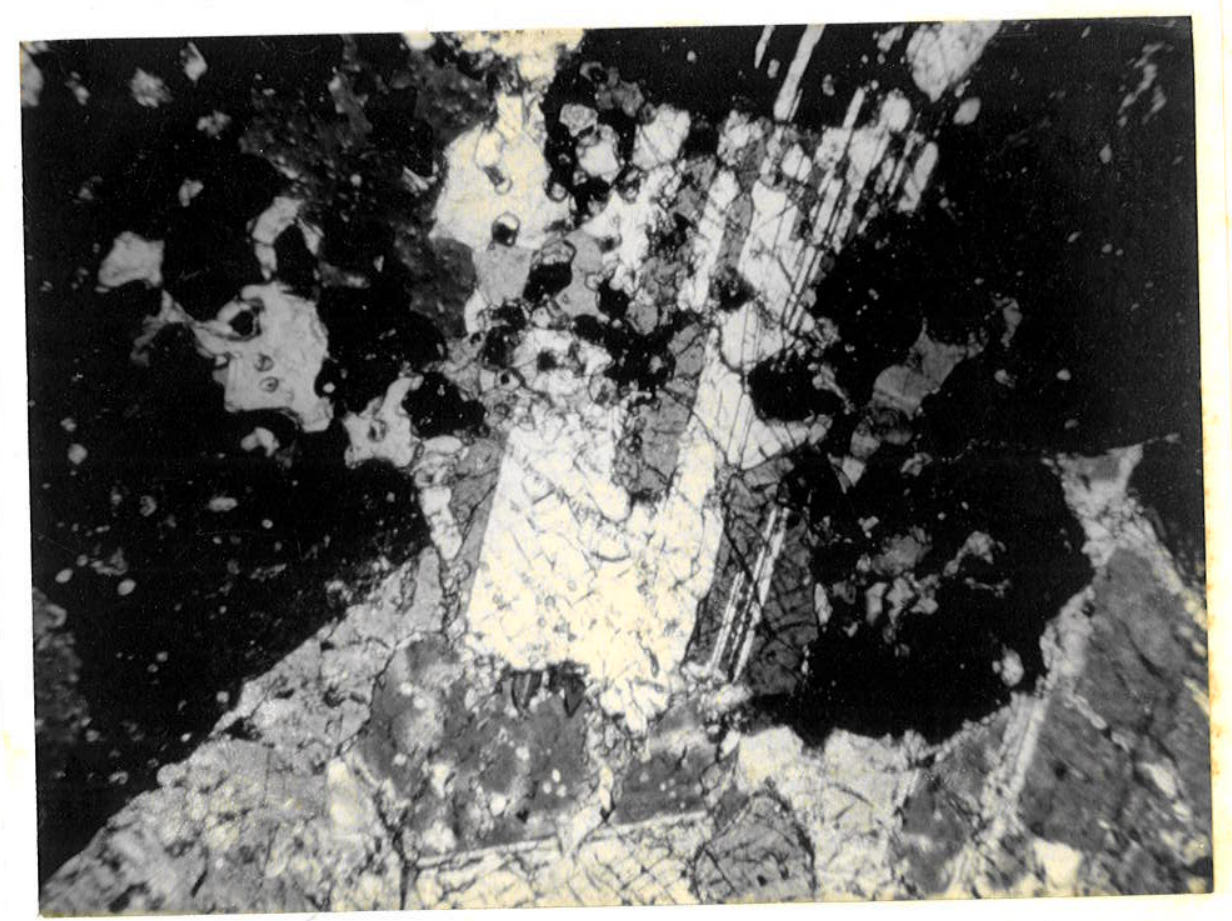

FOTO 31-Rocha calcossilicática. Clinopiroxênio (diopsỉidio) com inclusões de carbonato (calcita) e granada, apresentando geminação polissintética, associa do à granadas (extintas), carbonato e microclínio. Textura granobilástica. Amostra B5-10-67,1m. N. cruzados, X 88. 


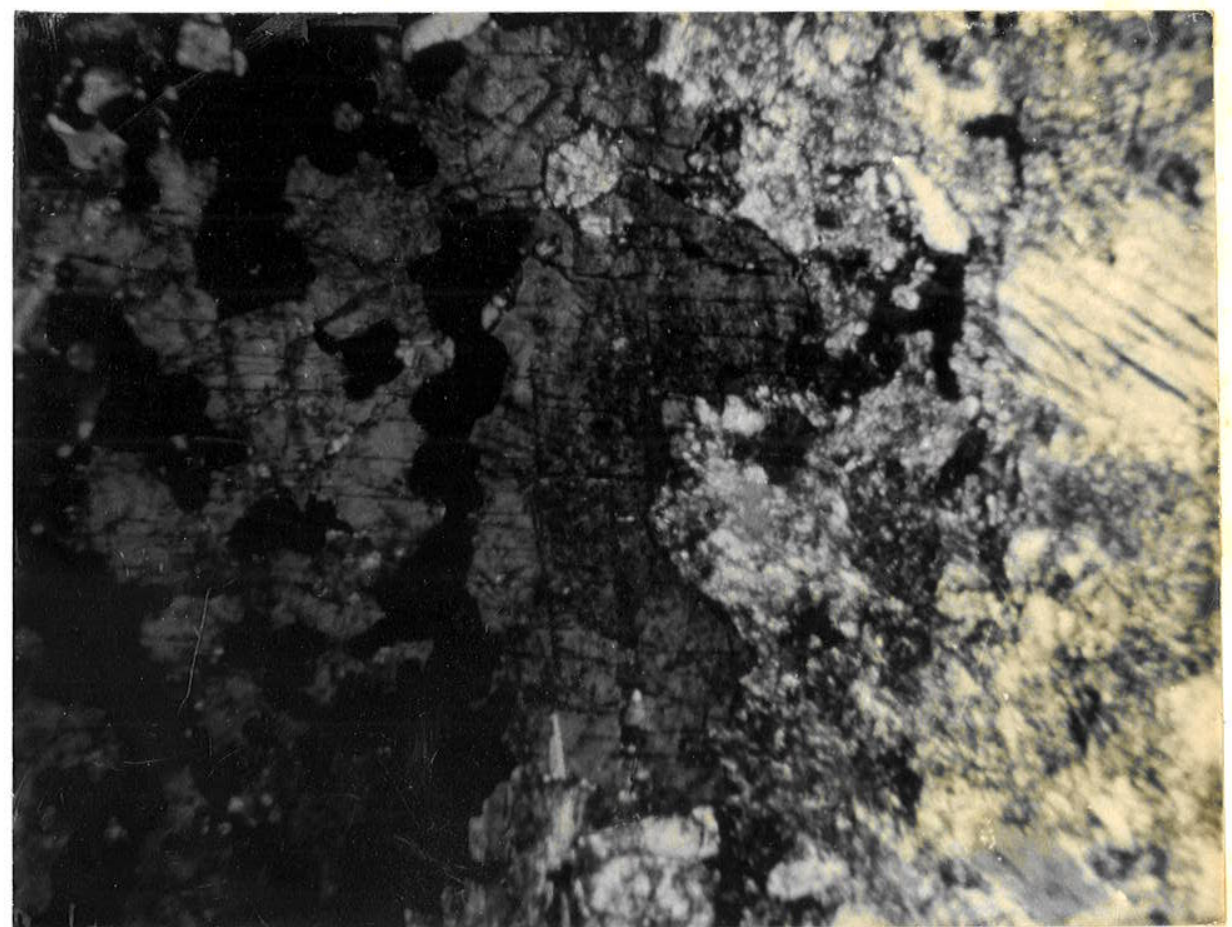

FOTO 32-Protominério de manganês. Braurita märmore. Porfiroblasto de rodo nita sendo cortada ou englobando opacos (braunita e hausmanita) associado a carbonatos (Mn-calcita), biotita e microclínio. Amostra B5-10-89,6m. N.cruzados, X 88 . 
CAPITULO IV

JAZIDA DE MANGANES DE SERRA DO NAVIO

IV - I - ASPECTOS GEOLOGICOS DE SERRA DO NAVIO

Os depōsitos de Manganēs de Serra do Navio estão loca lizados na parte este da Bacia Amazōnica, no centro do Territó rio Federal do Amapā, às margens do rio Amapari, a cerca de $1^{\circ}$ de latitude norte e $52^{\circ}$ de longitude este (SCARPELLI, 1963, 1968 e 1973, do qual a maioria dos dados deste tópico foram obtidos).

A região de Serra do Navio ē uma das mais acidentadas de todo o territorio sendo recoberta por florestas densas. Suas elevações mäximas, no entanto, não ultrapassam $360 \mathrm{~m}$.

No Distrito de Serra do Navio são distinguidos três ni veis de erosão estando o inferior situado ao redor da cota de $100 \mathrm{~m}$.

o Distrito è parte do escudo Prë-Cambriano das Guianas que nessa região $\bar{e}$ composto principalmente por gnaisses, conten do ainda em menor quantidade anfibolitos, xistos e quartzitos a]ēm de pegmatitos e veios de quartzo (Figura 8 ).

As rochas mais antigas da região são constituĩdas por gnaisses polimetamörficos Prë-Cambrianos, predominantemente leu cocräticos, contendo quartzo, microclínio, com ou sem oligocla a sio e biotita, possuindo zonas ricas em hornblendas escuras ge ralmente paralelas ä foliação.

Sobrepondo-se concordantemente aos gnaisses mais anti gos, estā a Sërie Amapä (denominação estratigräfica local) cor respondente ao Grupo Vila Nova que começa por anfibolitos do Gru po Jornal, localmente com lentes de xistos, gnaisses e quartzi 


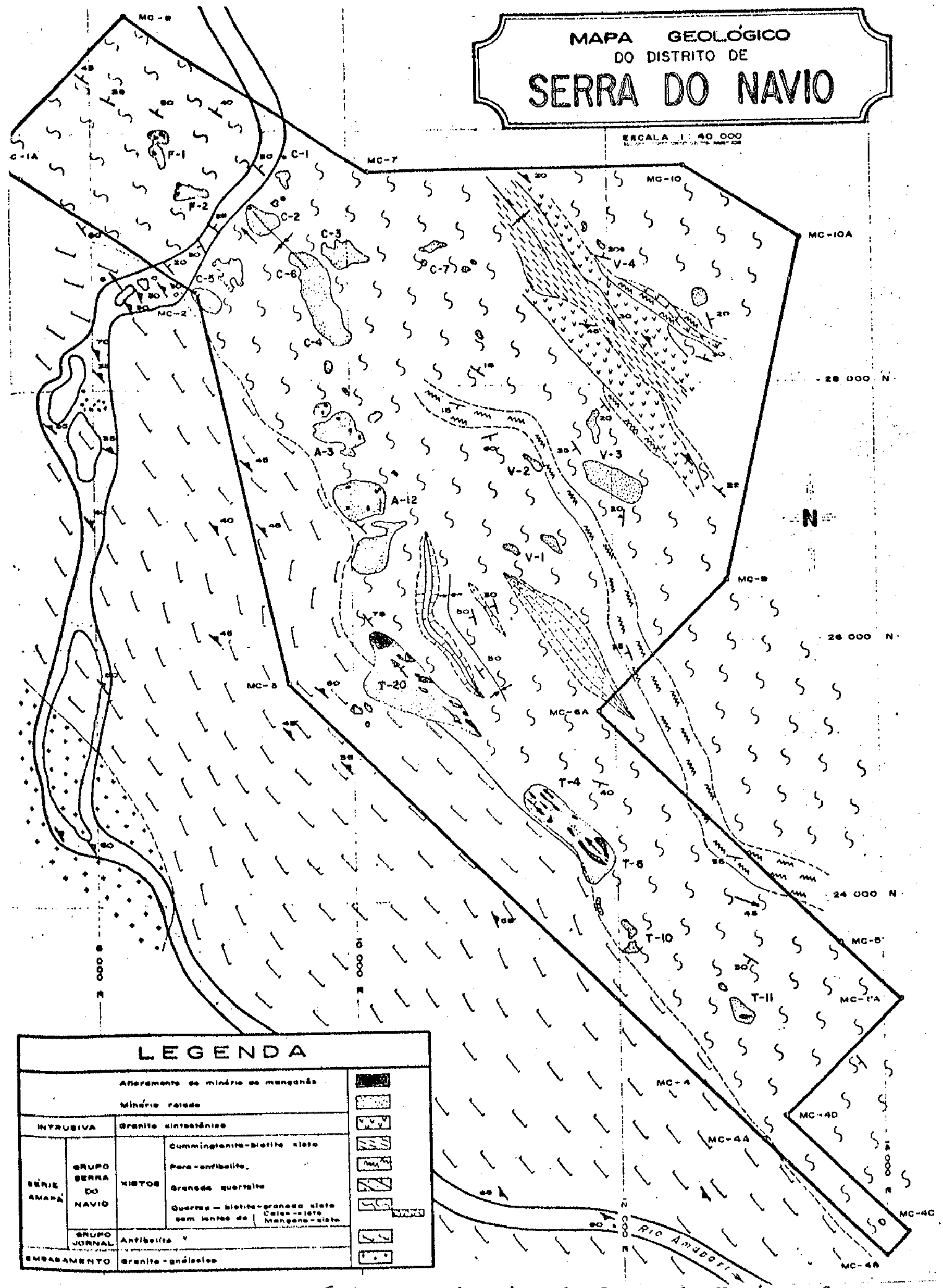

Figura 8 - Mapa geológico do Distrito de Serra do Navio - Segundo BARBOUR, 1965 - ICOMI. 
tos.

Esses anfibolitos são heterogēneos apresentando varia ções considerāveis, na textura e composição mineralógica, mesmo a pequenas distāncias, sendo constituỉdos principalmente por hornblenda verde seguida por andesina-oligocläsio. Em quantida des menores são encontrados quartzo, magnetita, titanita, diops dio, tremolita, carbonato e sulfetos. o quartzo ocorre também em veios.

SCARPELLI (1973) admite a possibilidade de que os anf $i$ bolitos sejam derivados de uma sequéncia heterogēnea de rochas, pela ocorrência das intercalações de quartzitos, gnaisses e bio tita xistos de foliação concordante.

Segundo esse autor, as evidências de campo não permi tem conclusões quanto à origem dos anfibolitos, entretanto, exis tem indicios de que pelo menos parte da sequência anfibolitica seja de origem sedimentar constatada pelas intercalações de quartzitos. Por outro lado, alguns gnaisses intercalados pos suem uma textura reliquiar tipicamente porfiritica indicando or gem ïgnea.

Anälises quïmicas realizadas por HERZ \& BANERJEE (1973) nos anfibolitos de Serra do Navio permitiram concluir que a ori gem ignea è a mais provävel.

Sobre os anfibolitos, existe uma nova sequência de me tassedimentos da. Série Amapä, Grupo Serra do Navio, composta de quartzitos, xistos e camadas ricas em carbonato, unidades essas que se alternam num padrão relativamente cĩclico repetido ao me nos trēs vezes.

Essas unidades são divididas em trēs fäcies distintas que contēm basicamente a mesma composição mineral, porëm em por centagens diferentes e que controlam a localização dos protomine rios de manganẽs.

A fäcies quartzîtica é composta por camadas silicosas rica's em quartzo e plagiocläsio, de granulação fina, com peque nas intercalações de rochas calcossilicatadas contendo minerais 
tais como, diopsidio, tremolita, titanita ou mesmo hornblenda.

A fäcies biotîtica ē representada por biotita xisto de granulação mais grosseira que as outras duas unidades, devido a recristalização mais intensa. Essa unidade è muito aluminosa e rica em minerais tipicamente produzidos por metamorfismo de sedi mentos peliticos, como: almandina, sillimanita, andalusita, bioti. ta e cordierita.

A fäcies grafitosa apenas se distingue das outras duas por sua alta concentração em grafita. Algumas vezes apresenta granulação fina, alto conteūdo em quartzo e acamamento bem pre servado, assemelhando-se ao da fäcies quartzïtica. Outras vezes apresenta maior semelhança com a fäcies biotîtica, possuindo gra nulaçãomais grosseira, boa foliação e planos de acamamento pou co reconheciveis.

os protominērios de manganês ocorrem na parte superior da fäcies grafitosa, como lentes de extensão e espessuras variă veis. Existem dois tipos de protominērios: protominērio carbonä tico que ocorre na parte imediatamente superior ā fäcies grafito sa e protominērio silicätico no contato entre o protominërio car bonätico e os xistos encaixantes.

ocasionalmente o protominērio ē associado as outras duas fäcies, porēm representando ocorrēncias menores (constitui das por lentes de apenas alguns decĩmetros de espessura).

A este do Distrito (SCARPELLI, 1966) ocorre uma intru são granîtica sintectōnica encaixada no pacote de xistos do Gru po Serra do Navio da Sērie Amapä, ocupando o alto de uma dobra anticlinal. E formada por um granito leucocrätico de granulação mëdia a grossa e às vezes pegmatöide. A orientação das micas e os planos de cizalhamento conferem a esse corpo uma xistosidade incipiente.

Ocorrem ainda localmente no Distrito alguns pegmatitos, veios de quartzo, diques de diabāsio e pequenos veios hidroter mais. 
Estruturalmente, a região de Serra do Navio é pouco co nhecida devido a escassez de afloramentos e a presença de rochas idênticas em diversos nïveis da coluna estratigräfica o que difi culta as correlações laterais.

As dobras variam de abertas a fechadas, mergulhando a NW e SE com ângulos variando de pequenos a moderados, tendo seus planos axiais mergulhando a NE. Localmente se tornam isoclinais com os flancos paralelos merguihando para NE.

os depositos de Manganēs da região foram formados por enriquecimento secundārio de protominērios carbonāticos e silicā ticos que ocorrem no Grupo Serra do Navio.

os principais minerais de minērio são essencialmente: criptomelana, polianita e pirolusita e subordinadamente a litio forita (VALARELLI, 1967, 1975).

IV - 2 - ESTUDO DOS PROTOMINERIOS E ENCAIXANTES DE SERRA DO NAVIO

$$
\text { IV - } 2-1-\text { GENERALIDADES }
$$

Normalmente os protominērios de manganēs de Serra do Navio são referidos como: a) protominërio carbonātico ou märmore manganesifero e, b) protominērio graratifero, algumas vezes de signado de "gonditico" ou sîlico carbonātico (SCARPELLI, 1963, $1968,1973)$.

No capitulo referente aos aspectos geolögicos de Serra do Navio foi vista de maneira geral a relação entre esses proto minērios e as rochas encaixantes de acordo com SCARPELLI, 1963 , 1968,1973 .

Os perfis das Figuras 9 e 10 são os que melhor repre sentam as estruturas e as relações entre protominērios e encaixan tes. 
Nota-se na Figura 9 (secção $\left.c_{2}-14+20\right)$ que o protominerio carbonätico é como que capeado por protominērio granatífero, ambos apresentando-se como lentes de dimensões variāveis interca ladas nos xistos encaixantes.

As lentes de protominērio carbonätico apresentam, de maneira geral, espessuras maiores que as de protominërio granati fero, e constituem o principal protominērio de manganês alcançan do em mëdia um teor de $30 \%$ de $\mathrm{Mn}$. O protominërio granatīfero con tëm de 5 a $20 \%$ de $\mathrm{Mn}$.

$$
\begin{aligned}
& \text { IV - } 2-2-\text { DESCRIÇÃO DE FUROS DE SONDA } \\
& \text { IV }-2-2-1-\text { FurO C-2-37 }
\end{aligned}
$$

0 furo 37 da jazidaC-2 atingiu uma profundidade de $135 \mathrm{~m}$, e cortou um pacote espesso de xistos encaixantes (Figura 9) atē $80 \mathrm{~m}$ constituîdos essencialmente de biotitas orientadas, sillimanita além de quartzo, plagioclāsios, anfibólios, gra nadas, cloritas e opacos (Fotos 33 e 34 ).

Importante $\bar{e}$ a presença de sillimanita em grande quan tidade em algumas amostras em forma de cristais fibrosos - ( $f \underline{j}$ brolita), assim como a presença de cordierita (Fotos $34,35,36$, $37,38)$.

Em alguns casos foi constatada andalusita frequentemente em transformação, para sillimanita (Foto 39). Em alguns casos ela sofre alteração restando apenas cristais sericitiza dos, muitas vezes somente com o nūcleo inalterado (Amostra $\mathrm{C}-2$ 37-99). Andaluzita ocorre também preservada dentro de cristais de granada (Fotos 40 e 41 ).

A porcentagem relativa dos minerais mencionados varia de acordo com a profundidade. Foram observadas amostras cons 


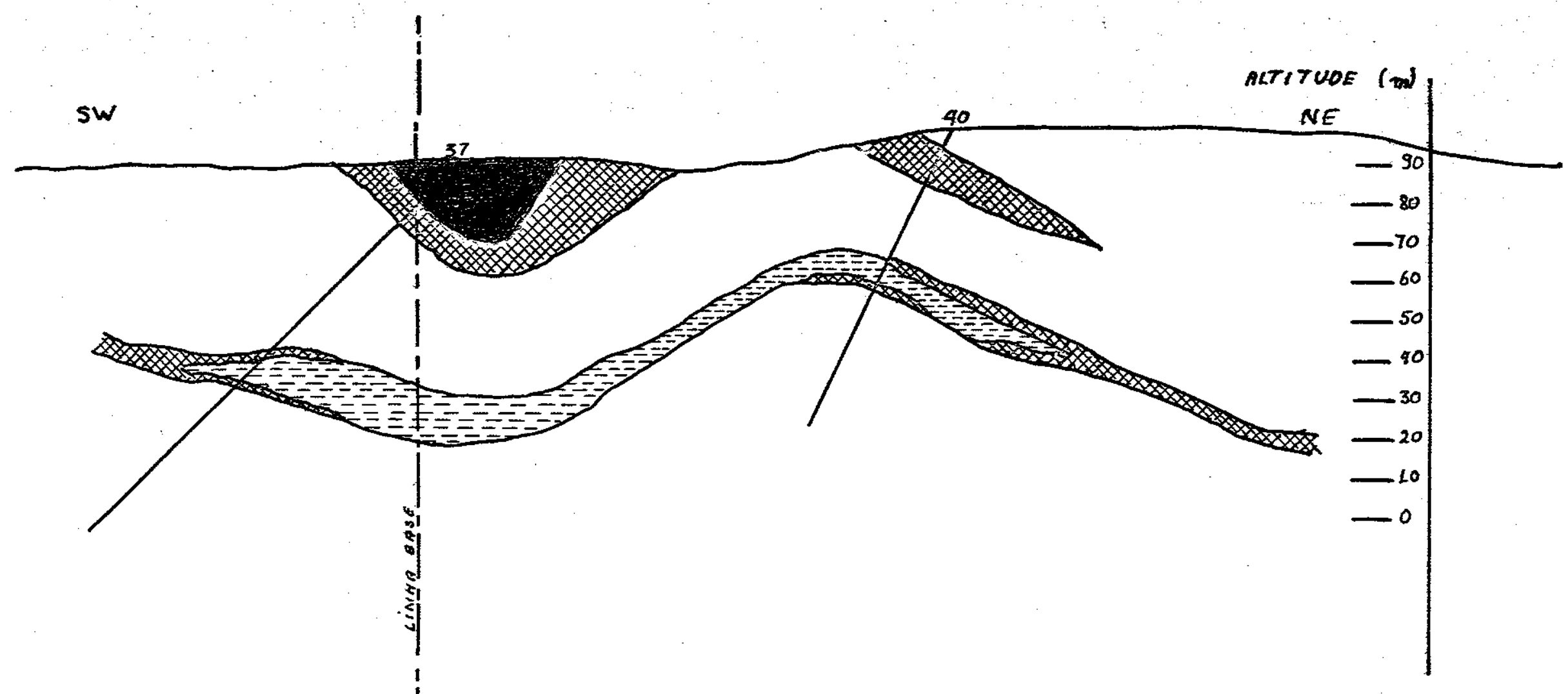

\section{UIII MINERIO GRANATIFERO}

MINERIO MACIÇO
MINERIO ROLADO
PROTOMINERIO GRANATIFERO
PROTOMINERIO CARBONATICO
JAZIDA C-2 SEÇAO $\quad 14+20$
ESCALA $1: 1000$

Figura 9 - Perfil geolögico da jazida C-2 - Seção 14+20 - ICoMI - 1965 - Escala $1: 1000$ com reducão de $38,5 \%$ 
tituĩdas por grande quantidade de quartzo e feldspato em detri mento de minerais micáceos e amostras em que estes minerais pre dominam ao lado de sillimanita e grande quantidade de opacos fi nos.

Amostras situadas mais prōximas ao contato com o proto minērio, apresentam porfiroblastos de granada em quantidade con siderävel (Fotos 40 e 41 ).

Acima do pacote de $x$ istos, entre os niveis $80 \mathrm{~m}$ e $65 \mathrm{~m}$, aproximadamente, o furo 37 corta uma lente de märmore manganes fero capeado no topo e na base por protominērio sîlico carbonä tico. A rocha silico carbonätica é constituida essencialmente de granada (espessartita) com uma quantidade relativa de 60 a $80 \%$, ao lado de quartzo, anfibö1io, carbonato,piroxenōides e/ou tefroita. Outro constituinte principal è a grafita, que ocorre disseminada por toda a rocha, e acessórios como apatita e pirofa nita.

Os carbonatos apresentam textura granoblästica em mo säico podendo tambëm aparecer com granulação fina e mal cristali zados principalmente dentro de granadas. Estas constituem, na maioria das vezes, porfiroblastos incluindo grafita e carbonatos finos, aparecendo tambëm como cristais pequenos com muito pouca inclusão, ou mesmo sem nenhuma. Piroxenöides e olivinas são tam bëm encontrados como porfiroblastos distribuĩdos de maneira uni forme por toda rocha.

os märmores manganesïferos cortados pelo furo 37 são rochas de textura granoblästica contendo essencialmente carbona tos ao 1 ado de espessartita, tefroita e grafita disseminada na massa de carbonatos. Em menor quantidade ocorrem piroxenóides e acessörios como anfibólios, pirofanita e sulfetos (Fotos 42 e 43).

Como no caso anterior, a granada contëm grande quanti dade de carbonato fino disseminado. os carbonatos das amostras estudadas apresentam-se bem cristalizados com textura em mosäico, salvo carbonatos finos "incluidos" em granadas. As olivinas e piroxenöides apresentam-se como porfiroblastos. Os piroxenóides 
foram tambēm, em alguns casos, constatados em veios. Veios de sericita proveniente da alteração de piroxenóides tambēm foram observados. Esta rocha constitui o principal protominērio de manganês pelo seu alto teor, $30 \% \mathrm{Mn}$.

$$
\text { IV }-2-2-2-\text { Furo } C-2-40
$$

0 furo 40 da jazida $C_{2}$ atinge uma sequencia de rochas xistosas que constituem as encaixantes de protominërio.

Trata-se de rochas orientadas, constituidas principal mente de biotita, sillimanita, quartzo e em alguns casos de cor dierita ao lado degranadas às vezes poiquiloblästicas. Como aces sōrios são comuns turmalina, apatita e titanita (Amostras C-2-40$-84 \mathrm{~m}$ e $(-2-40-66 \mathrm{~m}$ ) (Fotos $44,45,46$ e 47 ).

Nesse mesmo pacote existem ainda intercalações de ro chas calcossilicáticas constituĩdas por faixas alternadas de di ferentes granulações, possuindo em sua maior parte quartzo si tuado em faixas de granulação mais grosseira, ao lado de porfi blastos de granada, podendo ocorrer ainda epidoto, anfibölios, clinopiroxênios, flogopita e localmente carbonatos (Fotos 48 e 49). Nas faixas de granulação mais fina ocorrem epidoto, musco vita e prehnita, alēm de opacos finos e clorita. os cristais de epỉdoto às vezes aparecem cortados por veios de prehnita (Amos tra $c-2-40-72 \mathrm{~m})$. A titanita ocorre como acessōrio sendo que vāa rios cristais estão sofrendo alteração apresentando-se rodeados por opacos finos.

Acima da sequência de xistos e rochas călcossilicäti cas, o furo de sonda atravessa uma lente de rochas formadas principalmente por porfiroblastos de granada (espessartita) ao lado de feldspatos, grafita, anfibölios e biotita, tendo como acessōrios: apatita, pirofanita, titanita e alanita com uma textura granoblástica (Amostra c-2-40-55 m). 
0 märmore manganesîfero cortado por este furo (Figura 9) ë constituĩdo principalmente por carbonatos com textura em mo säico, granadas porfiroblästicas ou como cristais menores, sem pre poiquiloblásticas com inclusões de carbonato, tendo como aces sörio constante a grafita (Fotos 50, 51).

ocorrem ainda olivina, ora como pequenos cristais, ora como porfiroblastos incluindo carbonato e opacos (Fotos 50,51 , $52,53)$; rodonitas localizadas em contato com as olivinas e em alguns casos clorita em veios. E comum a presença de clorita den tro de granada. Pirofanita e apatita ainda ocorrem como acessó rios.

Acima dessas rochas existe uma sequencia de xistos com intercalações calcossilicáticas seguidas por uma lente com uma es pessura de $10 \mathrm{~m}$ de protominērios granatiferos.

$$
\text { IV }-2-2-3-\text { Furo F-12-76 }
$$

A Figura 10 mostra uma secção da Jazida F-12 onde se pode ver lentes mais espessas de protominërio carbonätico in tercaladas com lentes de protominërio silicătico, assim como sua alteração a minērios de manganês.

0 furo 76 dessa jazida atingiu espessa zona de protom $\underline{i}$. nërio carbonätico entre os nîveis 86 e $135 \mathrm{~m}$, cujas amostras fo ram estudadas em detalhe (vide dados de microssonda).

os principais minerais encontrados nessa rocha são: carbonatos com textura em mosáico; granadas às vezes porfirobläs ticas incluindo carbonatos finos; tefroitas ora porfiroblás ticas poiquiloblästicas, englobando carbonatos, ora como cris tais pequenos, ao lado de Mn-flogopita em quantidades variāveis de amostra para amostra. Piroxenöides de manganês são minerais comuns em muitas amostras às vezes em contato com tefroitas. Em alguns casos são tambëm poiquiloblästicos englobando carbonatos. Ainda podem ocorrer anfibölios, pirofanita e opacos finos (grafi 


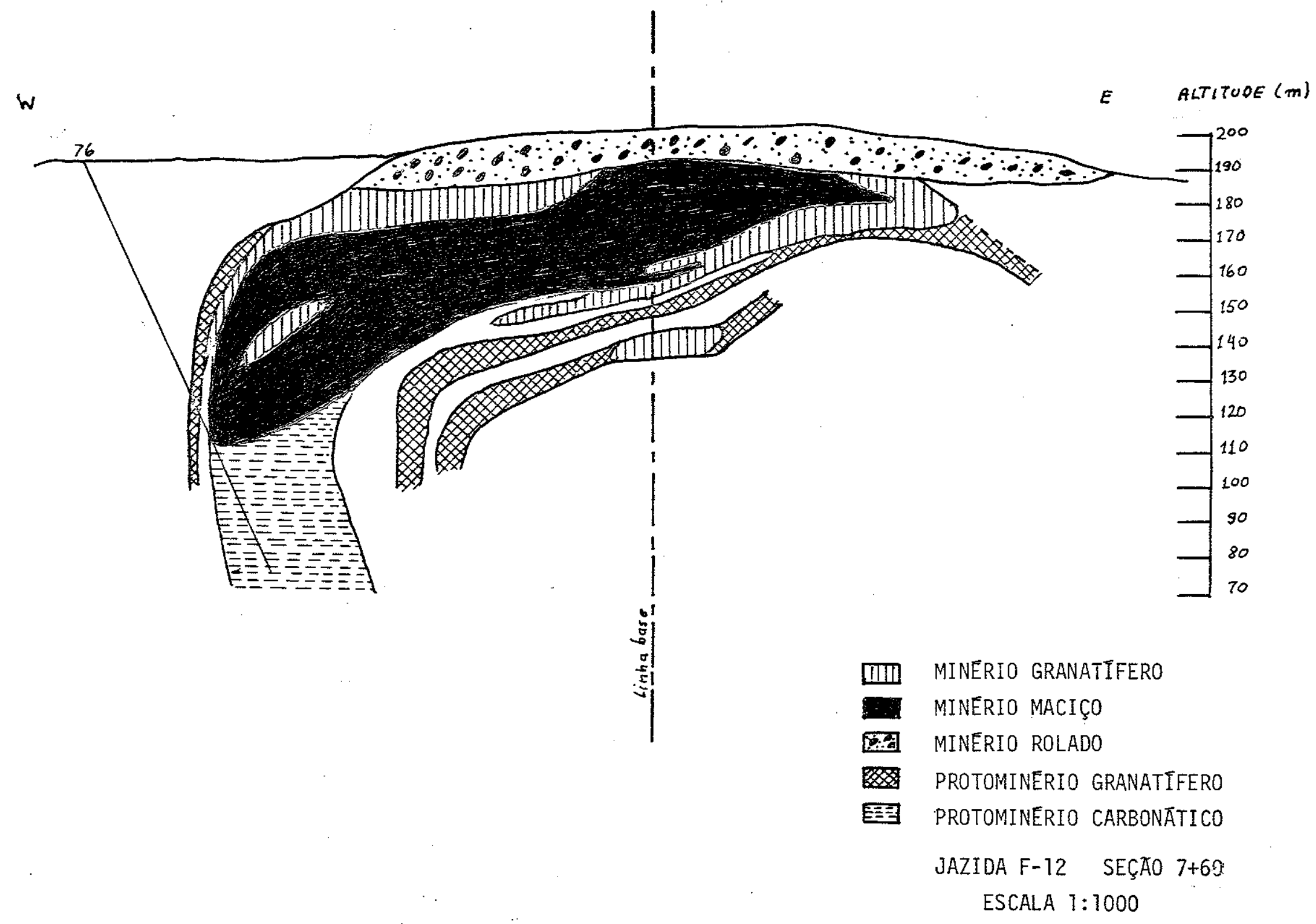

Figura 10 - Perfil geolögico da jazida F-12 - Seção 7+60 - ICOMI - 1965 - Escala 1:1000 com redução de $38,5 \%$ 
ta) (Fotos $54,55,56,57)$. Em algumas amostras è notävel a quantidade de pirofanita, disposta em faixas inclusive dentro de granadas, ocorrendo ao lado de Mn-flogopita (Fotos 58 e 59).

(Amostra F-12-76-117). A grafita encontra-se disseminada por toda a rocha (Fotos $54,55,58$ ).

Em algumas amostras os cristais de carbonato mostram- se relativamente alongados e orientados conferindo a rocha uma textura granoblästica orientada (Amostra F-12-76-94,8 m) (Foto 56).

Amostras dessa sequência foram bem caracterizadas como protominērios de manganēs carbonāticos.

$$
\text { IV }-2-2-4 \text { - Outras Amostras }
$$

Foram tamberm estudadas em detalhe amostras dos furos 74 da Jazida F-12, alêm da Jazida A-12 (Furos 12, 48, 25 e 50) e Jazida $T_{6}$ - furo 59 , de grande semelhança na composição das ro chas encaixantes bem como na dos protominērios jä descritos, o que mostram as Fotos 60 a 66 .

$$
\text { IV - } 2-3-\text { TIPOS DE PROTOMINERIO }
$$

Com base nestes estudos, pode-se concluir que de manei ra genërica existem dois tipos de protominērios em Serra do Na vio - carbonätico e granatifero.

0 protominērio carbonätico (Fotos $42,43,50,51,52$, $53,54,55,56,57,58,59)$ ou märmore manganesífero é formado essencialmente por Ca-kutnahorita-Caurodocrosita (carbonato) ao 1a do de espessartita, tefroita e grafita. Em menor quantidade ocorrem piroxenóides manganesiferos e acessörios como anfibölios, biotita, feldspato potässico e sulfetos. 
o protominērio granatífero (ou sîlico-carbonätico, ou queluzito) possui um alto conteúdo de espessartita ao lado de quartzo, clinoanfibölio e grafita que constituem os principais minerais. Podem ainda ser encontradas quantidades variāveis de acessörios como carbonato, titanita, biotita, clinopiroxênio,pi rofanita e sulfetos.

IV - 3 - MINERALOGIA DO PROTOMINERIO

Neste töpico serão descritas as propriedades dos mine rais constituintes dos protominērios de manganēs carbonätico e granatīfero, que foram determinadas atravës de tēcnicas de raios $X$, petrografia optica, anälises em Platina Universal de Federov e tēcnicas de microssonda eletrōnica.

As descrições texturais e as paragēneses desses mine rais, alëm de terem sido descritas e ilustradas anteriormentese rão objeto de novas considerações no item referente às condi ções de metamorfismo.

$$
\text { IV }-3-1-\text { CARBONATOS }
$$

Os carbonatos encontrados nos protominerios de serra do Navio (Fotos $43,44,51,52,54,56$ ) pertencem à série Ca-kutnahorita-Ca-rodocrosita.

os dados de composição química dos carbonatos deter minados atravēs da microssonda eletrōnica encontram-se na Tabe 1 a $X$ que fornece dados de porcentagem em peso e em porcentagem molar dos componentes detectados $-\mathrm{MnCO}_{3}, \mathrm{CaCO}_{3}, \mathrm{MgCO}_{3}$ e $\mathrm{FeCO}_{3}$.

$\mathrm{Na}$ mesma tabela, assim como na Figura 11 observa-se que a razão, Ca/Mn è aproximadamente constante em uma mesma amostra, apresentando porëm grande variação em diferentes furos 
TABELA $X$

ANALISES DE MICROSSONDA DE CARBONATOS DE PROTOMINERIOS DE Mn DE SERRA DO NAVIO

Peso\%

\begin{tabular}{|c|c|c|c|c|c|}
\hline AMOSTRA N & No & $\mathrm{NnCO}_{3}$ & $\mathrm{CaCO}_{3}$ & $\mathrm{MgCO}_{3}$ & $\mathrm{FeCO}_{3}$ \\
\hline$(2-37-81,1$ I & $I$ & 47,62 & 45,77 & 5,30 & 0,42 \\
\hline$(2-37-81,1 \quad I$ & I I & 48,13 & 44,20 & 6,20 & 0,43 \\
\hline$C 2-37-81,1 \mathrm{I}$ & II & 46,40 & 46,53 & 5,95 & 0,41 \\
\hline$(2-37-81, I I$ & I v & 45,54 & 46,83 & 5,42 & 0,57 \\
\hline$(2-37-81,1 \quad y$ & $y$ & 50,29 & 42,69 & 5,54 & 0,39 \\
\hline$C 2-37-81,1 \quad V$ & II & 46,68 & 46,00 & 5,49 & 0,57 \\
\hline$C 2-40-53,5$ I & 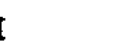 & 39,30 & 55,90 & 4,50 & 0,50 \\
\hline$C 2-40-53,5$ I & 11 & 39,10 & 56,20 & 4,50 & 0,48 \\
\hline $\mathrm{C} 2-40-53,5 \mathrm{I}$ & II & 38,90 & 56,90 & 4,10 & 0,56 \\
\hline $\mathrm{C} 2-40-53,5 \mathrm{I}$ & IV & 36,40 & 59,70 & 4,10 & 0,35 \\
\hline $\mathrm{C} 2-40-53,5 \mathrm{~V}$ & 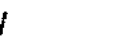 & 40,20 & 54,40 & 4,90 & 0,54 \\
\hline $\mathrm{C} 2-40-53,5 \mathrm{~V}$ & 11 & 40,40 & 54,90 & 4,90 & 0,68 \\
\hline$F 12-76-94,8$ & $I$ & 67,75 & 16,53 & 8,57 & 5,32 \\
\hline F $12-76-94,8$ & 11 & 69,19 & 14,83 & 9,02 & 5,39 \\
\hline$F 12-76-94,8$ & IV & 68,43 & 16,19 & 8,52 & 5,32 \\
\hline$F 12-76-122$ & 1 & 70,06 & 15,63 & 9,91 & 3,21 \\
\hline F $12-76-122$ & II & 69,66 & 16,99 & 8,90 & 2,60 \\
\hline$F 12-76-1<2$ & III & 69,29 & 18,24 & 8,85 & 2,58 \\
\hline F 12-76-122 & IV & 69,29 & 18,24 & 8,85 & 2,59 \\
\hline $512-76-111,7$ & $I$ & 70,45 & 15,23 & 9,45 & 2,12 \\
\hline$F 12-76-111,7$ & III & 69,94 & 15,81 & 9,33 & 2,07 \\
\hline$F 12-76-111,7$ & IV & 70,66 & 15,13 & 3,53 & 2,15 \\
\hline$F 12-76-111,7$ & $v$ & 71,20 & 15,15 & 9,43 & 2,15 \\
\hline F 12-76-117 & $I$ & 63,77 & 28,54 & 6,82 & 1,92 \\
\hline$F 12-76-117$ & IV & 58,44 & 31,56 & 6,67 & 1,46 \\
\hline$F 12-76-117$ & V & 56,05 & 35,31 & 6,06 & 1,43 \\
\hline$F 12-76-117$ & VI & 54,63 & 36,63 & 5,72 & 1,41 \\
\hline$F 12-76-117$ & VII & 61,59 & 28,78 & 7,07 & 1,66 \\
\hline$T 12-12-90,5$ & $I$ & 69,69 & 27,30 & 6,57 & 1,18 \\
\hline $112-12-90,5$ & III & 67,36 & 21,36 & 7,93 & 1,22 \\
\hline$T 12-12-90,5$ & IV & 69,21 & $20,5]$ & 7,82 & 1,27 \\
\hline T $12-12-90,5$ & VI & 68,08 & 21,24 & 7,93 & 1,28 \\
\hline
\end{tabular}

Mol \%

$\begin{array}{llll}\mathrm{MnCO}_{3} & \mathrm{CaCO}_{3} & \mathrm{MgCO}_{3} & \mathrm{FeCO}_{3} \\ 44,16 & 48,75 & 6,70 & 0,38 \\ 44,70 & 47,10 & 7,80 & 0,40 \\ 42,80 & 49,30 & 7,50 & 0,40 \\ 41,80 & 51,30 & 6,50 & 0,40 \\ 46,90 & 45,70 & 7,00 & 0,40 \\ 43,40 & 49,10 & 7,00 & 0,50 \\ 36,14 & 57,99 & 5,41 & 0,46 \\ 35,92 & 58,24 & 5,40 & 0,43 \\ 35,70 & 58,88 & 4,91 & 0,50 \\ 33,26 & 61,54 & 4,89 & 0,32 \\ 37,05 & 56,55 & 5,89 & 0,49 \\ 36,93 & 56,61 & 5,84 & 0,62 \\ 65,34 & 18,31 & 11,26 & 5,09 \\ 66,61 & 16,40 & 11,84 & 5,15 \\ 65,86 & 17,89 & 11,17 & 5,08 \\ 66,91 & 17,15 & 12,90 & 3,04 \\ 67,00 & 18,77 & 11,67 & 2,56 \\ 66,05 & 19,96 & 11,50 & 2,49 \\ 66,05 & 19,96 & 11,50 & 2,49 \\ 68,40 & 17,05 & 12,51 & 2,05 \\ 67,99 & 17,65 & 12,36 & 2,00 \\ 68,50 & 16,84 & 12,60 & 2,07 \\ 68,74 & 16,80 & 12,41 & 2,06 \\ 58,80 & 30,70 & 8,70 & 1,80 \\ 55,53 & 34,44 & 8,65 & 1,39 \\ 52,73 & 38,15 & 7,78 & 1,34 \\ 56,83 & 23,46 & 8,59 & 1,12 \\ 58,11 & 22,50 & 10,19 & 1,21 \\ 65,11 & 23,33 & 10,34 & 1,21\end{array}$




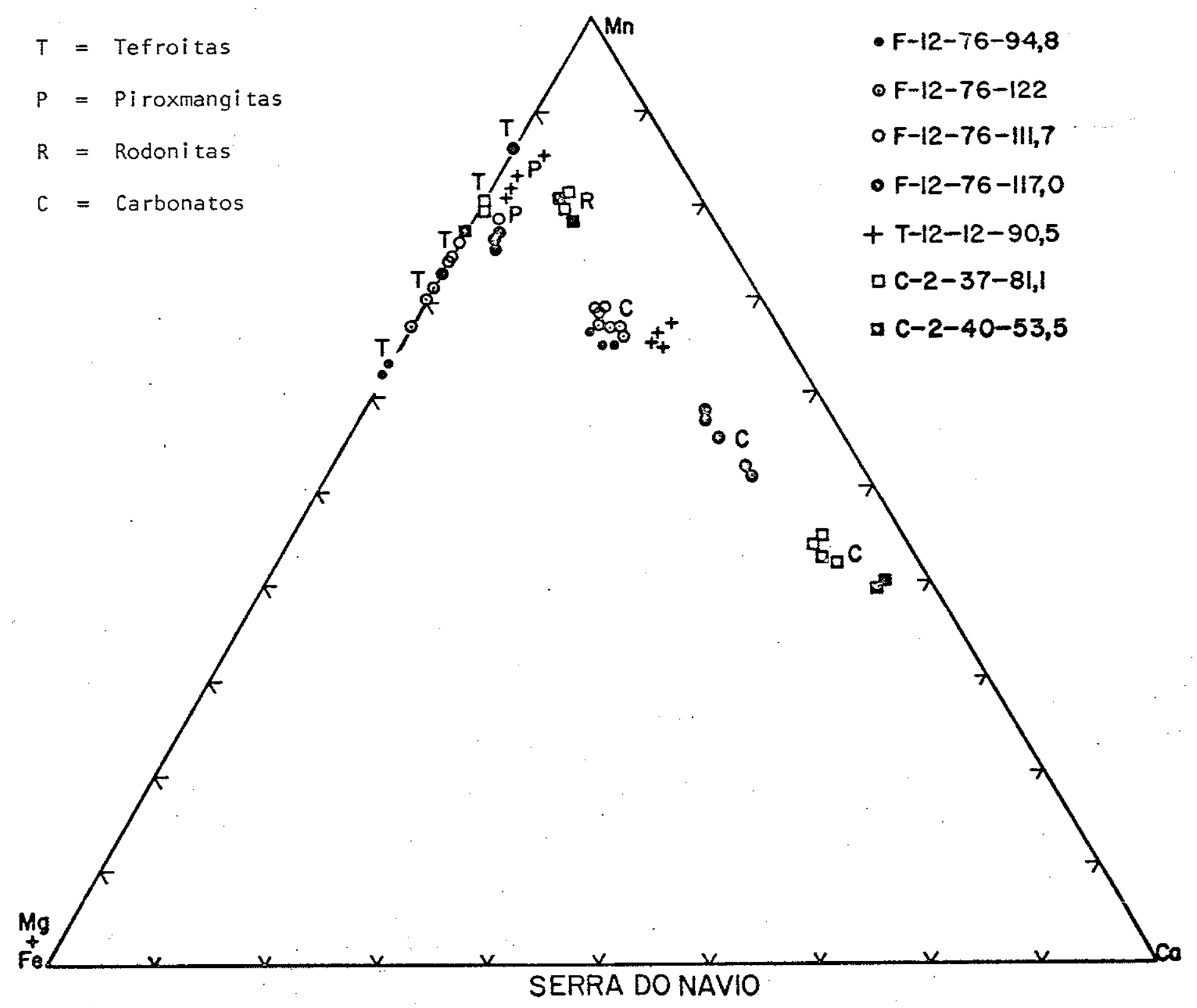

Figura 11 - Diagrama triangular em porcentagem molar de (Mn)-(Ca)-(Fe+Mg) de carbonatos, rodonitas, piroxmangitas e tefroitas de amostras de protominério de manganês de Serra do Navio. 
de sonda e em diferentes minas. A quantidade de $M g$ e Fe dos car bonatos estä relacionada à razão $\mathrm{Ca} / \mathrm{Mn}$; quanto maior essa rela ção menor o conteūdo de $(\mathrm{Fe}+\mathrm{Mg})$ dos carbonatos.

Alēm desses dados foram feitas medidas do indice de re fração $n_{w}$ variando entre 1,72 e 1,78 e determinação de $\Delta d_{104}=$ $(0,14$ a 0,06$)$ em estreita correlação com os dados de microsson da.

\section{IV - 3-2-PIROXENOIDES}

Dois tipos de piroxenöides, rodonita (Foto 42) e pirox mangita (Fotos $54,55,58$ ) foram encontrados nos protominërios de Serra do Navio.

A piroxmangita é encontrada mais frequentemente e como pode ser observado pelas Figuras 11 e 27 é associada a carbona tos mais ricos na molēcula $\mathrm{MnCO}_{3}$.

Em três lâminas delgadas foram realizadas dezoito de terminações de propriedades ópticas da piroxmangita tais como me dida do ângulo $2 \mathrm{~V}$ entre os eixos ópticos, medida do ângulo entre as clivagens (110) (110) e medida do ângulo entre direçóes ōpti cas e direções cristalogräficas $(\gamma \wedge z)$.

Para o ângulo axial $2 \mathrm{~V}$ obteve-se uma variação mëdia de 42,7 a $43,0^{\circ}$; o ângulo entre as clivagens variou de $89,5^{\circ}$ a $90,8^{\circ}$ (média) e o valor médio do ângulo entre o indice de refra ção maior $\gamma$ e a direção cristalogräfica $Z$ variou de $43,0^{\circ}$ a $44,0^{\circ}$ (Tabela XVI).

Dados öpticos das rodonitas foram obtidos em ' värias secções delgadas. De uma maneira geral, o valor do ângulo axial $2 V$ variou de $60,0^{\circ}$ a $64,0^{\circ}$, o ânguro entre o indice $\gamma$ e o eixo $Z$, de $34,0^{\circ}$ a $40,0^{\circ}$ e os ângulos entre as clivagens de $88,0^{\circ}$ a $93,0^{\circ}$.

A porcentagem em peso dos componentes $\mathrm{SiO}_{2}$, MnO, CaO, 
Mg0 e Fe0, obtidos por microssonda eletrônica, de piroxmangitas e rodonitas, bem como os dados relativos ao nümero de ions com base em três oxigênios, estão na Tabela XI. Observa-se que 0 conteūdo de $\mathrm{CaSiO}_{3}$ das piroxmangitas não ultrapassa a $3,5 \mathrm{~mol} \%$, enquanto que para as rodonitas o mais baixo teor de $\mathrm{CaSiO}_{3} \overline{\mathrm{e}}$ de $7 \mathrm{~mol} \%$.

Na Figura 11 vemos que a rodonita coexiste com carbona tos mais ricos em cálcio e a piroxmangita com carbonatos mais ricos na motécula $\mathrm{MnCO}_{3}$.

Ainda com base na Tabela XI constata-se que o teor de $\mathrm{FeSiO}_{3}+\mathrm{MgSiO}_{3}$ das piroxmangitas varia de 12 a 27 mol\% sendo, portanto, maior que para as rodonitas.

Nos protominêrios de Serra do Navio não foram encon trados clinopiroxénios coexistentes com rodonita.

$$
\text { IV }-3-3-\text { TEFROITAS }
$$

A tefroita alèm dos carbonatos é o mineral mais comum nos protominërios carbonäticos de manganës. Aparece na maioria das vezes como porfiroblastos englobando outros minerais principalmen te carbonatos (Fotos 42, 50, 51, 52, 53, 55, 57).

Dados opticos de Platina Universal para as tefroitas são apresentados na Tabela XVII.

A variação mëdia obtida para o ângulo $2 \mathrm{~V}$. foi de $51,3^{\circ}$ a $60,1^{\circ}$ e os àngulos entre as clivagens muitas vezes mal de finidas variaram de $87,5^{\circ}$ a $91,6^{\circ}$.

Dados de microssonda eletrōnica de tefroitas. (Tabela XII) mostram que ao lado de manganēs, encontram-se quantidades apreciāveis de magrēsio e ferro dependendo da composição dos car bonatos coexistentes, relação que tambëm pode ser vista na Figu ra 11 . 
TABELA XI - ANALISES DE MICROSSONDA DE PIROXENOIDES DE PROTOMINERIOS DE Mn DE SERRA DO NAVIO

\begin{tabular}{|c|c|c|c|c|c|c|c|c|c|c|c|}
\hline \multirow{3}{*}{ AMOSTRA NO } & \multicolumn{6}{|c|}{ Peso \% } & \multicolumn{5}{|c|}{ Nümero de ions com base em 3 oxigēnios } \\
\hline & & $\mathrm{SiO}_{2}$ & Mno & $\mathrm{CaO}$ & $\mathrm{MgO}$ & $\mathrm{FeO}$ & si & $M n$ & $\mathrm{Ca}$ & $\mathrm{Mg}$ & $\mathrm{Fe}$ \\
\hline & \multicolumn{11}{|c|}{ Piroxmangitas } \\
\hline$F 12-76-111,7$ & II & 49,96 & 43,20 & 0,96 & 5,02 & 2,53 & 1,02 & 0,75 & 0,02 & 0,15 & 0,04 \\
\hline F12-76-117 & II & 47,71 & 43,08 & 1,26 & 5,12 & 3,25 & 1,00 & 0,76 & 0,03 & 0,16 & 0,06 \\
\hline F12-76-117 & IV & 49,05 & 43,62 & 1,17 & 5,10 & 2,90 & 1,01 & 0,76 & 0,03 & 0,16 & 0,05 \\
\hline F12-76-117 & $\mathrm{v}$ & 48,75 & 44,17 & 1,27 & 4,85 & 3,09 & 1,00 & 0,77 & 0,03 & 0,15 & 0,05 \\
\hline F12-76-117 & VI & 48,85 & 44,19 & 1,29 & 4,74 & 3,04 & 1,00 & 0,77 & 0,03 & 0,14 & 0,05 \\
\hline F12-76-117 & VII & 48,32 & 44,79 & 1,21 & 4,59 & 2,87 & 1,00 & 0,78 & 0,03 & 0,14 & 0,05 \\
\hline$T 12-12-90,5$ & I & 48.97 & 46,27 & 1,07 & 3,77 & 1,78 & 1,01 & 0,81 & 0,02 & 0,12 & 0,03 \\
\hline$T 12-12-90,5$ & II I & 47,87 & 47,55 & 1,17 & 2,76 & 1,59 & 1,01 & 0,85 & 0,03 & 0,09 & 0,03 \\
\hline$T 12-12-90,5$ & IV & 48,44 & 46,56 & 1,09 & 3,40 & 1,73 & 1,01 & 0,82 & 0,02 & 0,11 & 0,03 \\
\hline$T 12-12-90,5$ & $V I$ & 48,16 & 46,96 & 1,24 & 3,36 & 1,69 & 1,00 & 0,83 & 0,03 & 0,10 & 0,03 \\
\hline \multicolumn{12}{|c|}{ Rodonitas } \\
\hline$C 2-37-81,1$ & I & 48,43 & 45,94 & 3,31 & 3,20 & 0,89 & 1,00 & 0,81 & 0,07 & 0,10 & 0,02 \\
\hline$c 2-37-81,1$ & II & 48,06 & 46,14 & 3,02 & 3,42 & 0,90 & 1,00 & 0,81 & 0,07 & 0,11 & 0,02 \\
\hline$(2-37-8], 1$ & III & 48,38 & 45,24 & 3,24 & 3,41 & 0,99 & 1,00 & 0,80 & 0,07 & 0,11 & 0,02 \\
\hline$C 2-37-81,1$ & IV & 48,70 & 46,64 & 3,27 & 3,18 & 0,71 & 1,00 & 0,81 & 0,07 & 0,10 & 0,01 \\
\hline$(2-37-81,1$ & $v$ & 48,72 & 45,93 & 3,04 & 3,24 & 1,24 & 1,00 & 0,80 & 0,07 & 0,10 & 0,02 \\
\hline$c 2-40=53,5$ & I & 47,32 & 44,39 & 3,50 & 3,38 & 1,28 & 1,00 & 0,79 & 0,08 & 0,11 & 0,02 \\
\hline$C 2-40-53,5$ & III & 47,52 & 44,05 & 3,52 & 3,46 & 1,43 & 1,00 & 0,79 & 0,08 & 0,11 & 0,03 \\
\hline$c 2-40-53,5$ & IV & 47,69 & 43,97 & 3,40 & 3,58 & 1,65 & 1,00 & 0,79 & 0,08 & 0,11 & 0,03 \\
\hline$c 2-40-53,5$ & VI & 47,95 & 43,61 & 4,01 & 3,50 & 1,58 & 1,00 & 0,77 & 0,09 & 0,11 & 0,03 \\
\hline
\end{tabular}


TABELA XII - ANALISES DE MICROSSONDA DE TEFROITAS DE PROTOMINERIOS DE Mn DE SERRA DO NAVIO

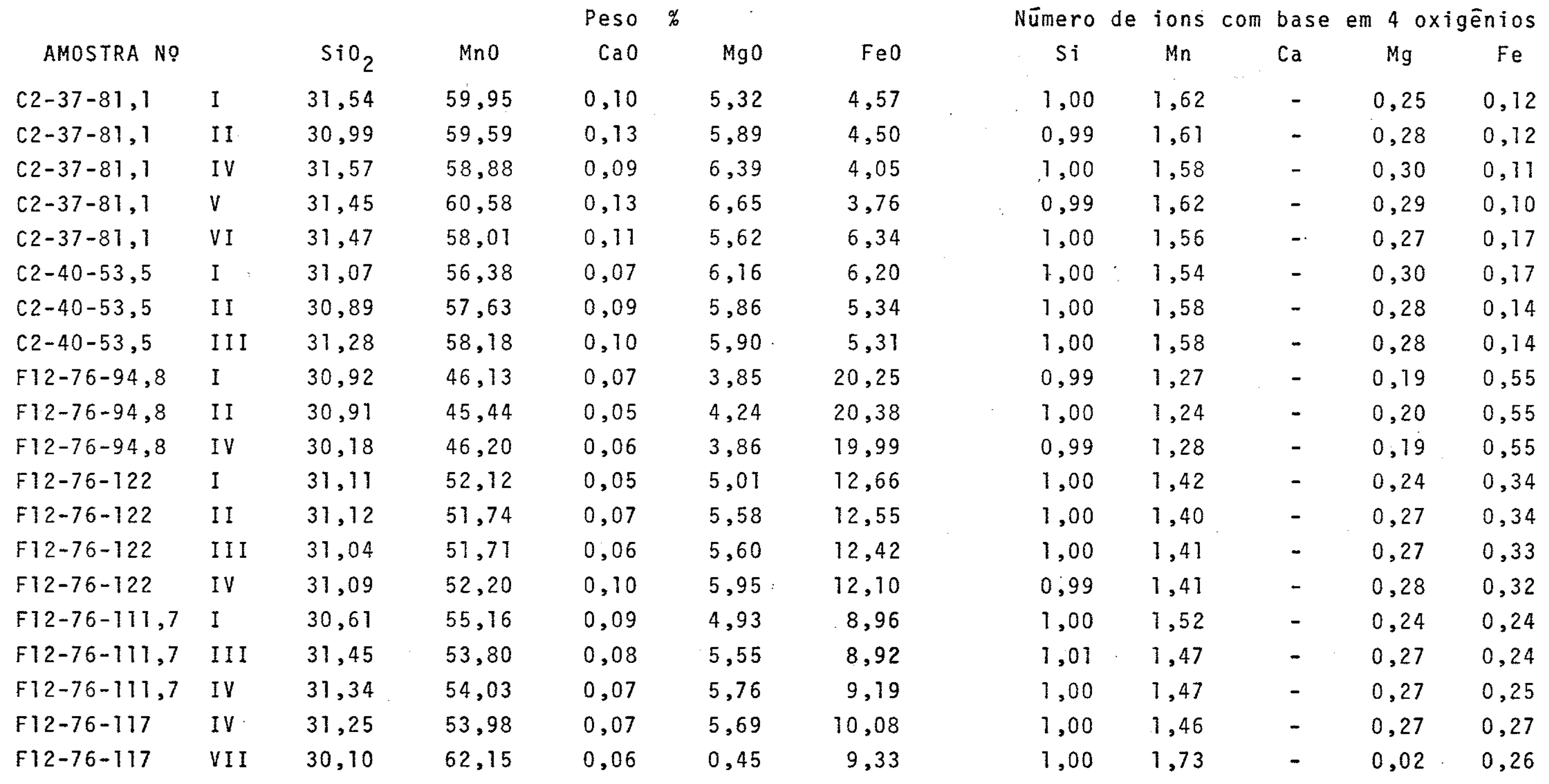


Nas olivinas, as relações $\left(\mathrm{Mg}^{2+}+\mathrm{Fe}^{2+}\right) / \mathrm{Mn}^{2+}$ e $\mathrm{Fe}^{2+} /$ $\left(\mathrm{Fe}^{2+}+\mathrm{Mg}^{2+}\right)$ são maiores que nos carbonatos e piroxenöides coe xistentes, ao mesmo tempo, as porcentagens de $\mathrm{Ca}_{2} \mathrm{SiO}_{4}$ (larnita) nessas tefroitas ē muito baixa.

$$
\text { IV }-3-4-\text { ESPESSARTITA }
$$

A espessartita $\vec{e}$ encontrada principalmente nos proto minērios queluzīicos, podendo porém aparecer em grandes quantida des nos protominērios carbonāticos. Espessartita ocorre como cristais grandes poiquiloblästicos ou pequenos, sendo que os maiores possuem muita inclusão de grafita e carbonato fino dis seminado (Fotos 43, 50, 51, 53, 54,55, 58, 59).

os resultados das anälises por microssonda eletrōnica das granadas acham-se tabelados (Tabela XIII). Nessa tabela ve rifica-se que o conteüdo do componente espessartita ē muito al to, cerca de $90 \%$, possuindo em menores quantidades os componen tes grossularia, almandina e piropo.

As quantidades de grossularia e almandina estão rela cionadas à composição dos carbonatos coexistentes; o conteüdo de piropo è aproximadamente constante o que indica que seu 1 imi te de solução sölida foi atingido.

Medidas de indices de refração assim como o estudo de raios $X$ com medidas de parāmetros da cela das granadas confir mam dados de microssonda eletrónica (Tabela XIII).

$$
\text { IV - } 3-5-\text { FLOGOPITA MANGANESTFERA }
$$

Essa flogopita $\bar{e}$ um mineral muito comum em amostras que possuem carbonatos ricos em magnésio (Fotos 54, 55, 56, 57, 58, 59). Medidas öpticas forneceram āngulo entre os eixos ōp 
TABELA XIII - ANALISES DE MICROSSONDA DE ESPESSARTITAS DE PROTOMINERIOS DE Mn DE SERRA DO NAVIO

\begin{tabular}{|c|c|c|c|c|c|c|c|c|c|c|c|c|c|c|c|}
\hline \multirow{2}{*}{\multicolumn{2}{|c|}{ AMOSTRA NO }} & \multirow[b]{2}{*}{$\mathrm{SiO}_{2}$} & \multicolumn{4}{|c|}{ Peso \% } & & \multirow[b]{2}{*}{$\mathrm{TiO}_{2}$} & \multicolumn{2}{|c|}{ Nümero de } & ions & \multicolumn{2}{|c|}{ om base em 12} & \multicolumn{2}{|c|}{ oxigennios } \\
\hline & & & $\mathrm{A}_{2} 2^{\mathrm{O}} 3$ & Cao & Mno & $\mathrm{MgO}$ & & & $\mathrm{Ti}$ & si & Al & $\mathrm{Ca}$ & $\mathrm{Mn}$ & $\mathrm{Mg}$ & $\mathrm{Fe}$ \\
\hline$C 2-37-81,1$ & I & 37,34 & 20,74 & 1,91 & 40,26 & 0,59 & 0,82 & n.d. & - & 3,01 & 1,97 & 0,76 & 2,75 & 0,07 & 0,06 \\
\hline$C 2-37-81,1$ & II & 37,47 & 21,22 & 1,73 & 40,69 & 0,61 & 0,66 & n.d. & - & 2,99 & 2,00 & 0,15 & 2,75 & 0,07 & 0,04 \\
\hline$(2-37-81,1$ & V & 37,63 & 20,62 & 1,78 & 40,47 & 0,63 & 0,58 & n.d. & - & 3,02 & 1,95 & 0,15 & 2,75 . & 0,07 & 0,04 \\
\hline$C 2-40-53,5$ & I & 36,63 & 20,86 & 2,51 & 38,36 & 0,61 & 0,88 & n.d. & - & 2,99 & 2,07 & 0,22 & 2,65 & 0,07 & 0,06 \\
\hline$C 2-40-53,5$ & V & 36,95 & 21,27 & 1,88 & 39,14 & 0,64 & 1,09 & n.d. & - & 2,98 & 2,02 & 0,16 & 2,68 & 0,08 & 0,07 \\
\hline F12-76-122 & I & 37,31 & 21,64 & 1,15 & 39,03 & 0,66 & 2,21 & n.d. & - & 2,99 & 2,04 & 0,10 & 2,64 & 0,08 & 0,15 \\
\hline$F 12-76-122$ & II & 37,62 & 21,27 & 1,59 & 38,77 & 0,70 & 2,39 & 0,06 & - & 3,00 & 2,00 & 0,14 & 2,62 & 0,08 & 0,16 \\
\hline$F 12-76-122$ & III & 37,28 & 27,51 & 1,97 & 38,72 & 0,66 & 2,19 & n.d. & - & 2,98 & 2,02 & 0,17 & 2,62 & 0,08 & 0,13 \\
\hline $\mathrm{F} 12-76-111,7$ & IV & 37,46 & 20,84 & 1,29 & 39,25 & 0,69 & 1,60 & n.d. & - & 3,02 & 1,98 & 0,11 & 2,68 & 0,08 & 0,11 \\
\hline $512-76-111,7$ & V & 36,60 & 20,81 & 1,65 & 38,83 & 0,79 & 1,45 & 0,32 & 0,04 & 2,99 & 2,00 & 0,14 & 2,68 & 0,10 & 0,10 \\
\hline Fi2-76-117 & II & 37,20 & 20,89 & 1,81 & 39,25 & 0,66 & 1,57 & 0,76 & 0,02 & 3,00 & 1,99 & 0,16 & 2,68 & 0,08 & 0,11 \\
\hline F12-76-117 & V & 37,35 & 20,95 . & 1,83 & 39,65 & 0,56 & 1,65 & n.d. & - & 3,00 & 1,98 & 0,16 & 2,70 & 0,07 & 0,11 \\
\hline F12-76- 117 & VI & 37,21 & 21,20 & 1,95 & 39,06 & 0,53 & 1,64 & n.d. & - & 2,99 & 2,01 & 0,17 & 2,66 & 0,06 & 0,11 \\
\hline T12-12-90,5 & I & 37,46 & 21,39 & 1,28 & 40,42 & 0,60 & 0,32 & n.d. & - & 3,00 & 2,02 & 0,11 & 2,74 & 0,07 & 0,06 \\
\hline$T 72-72=90,5$ & III & 36,90 & 21,23 & 1,21 & 40,47 & 0,50 & 0,96 & n.d. & - & 2,98 & 2,02 & 0,11 & 2,77 & 0,06 & 0,07 \\
\hline$T 72-12-90,5$ & IV & 36,98 & 21,41 & 1,19 & 40,47 & 0,62 & 0,95 & n.d. & - & 2,98 & 2,03 & 0,10 & 2,76 & 0,07 & 0,06 \\
\hline$T 12-12-90,5$ & VI & 37,32 & 21,13 & 1,57 & 39,73 & 0,64 & 0,06 & n.d. & - & 3,00 & 2,00 & 0,14 & 2,71 & 0,08 & - \\
\hline
\end{tabular}


ticos (2V) aproximadamente igual a $34-35^{\circ}$. Ocorrem como placas com pleocroismo variando de amarelo esverdeado a castanho claro.

Na Tabela XIV são vistos os dados de microssonda da flogopita. Seu conteūdo de manganēs. é aproximadamente constan te, mas a razão $\mathrm{Fe}^{2+} / \mathrm{Fe}^{2+}+\mathrm{Mg}^{2+}$ estä relacionada com os carbona tos e tefroitas coexistentes.

$$
\text { IV }-3-6-\text { ANFIBOLIOS }
$$

Anfibōlios são raros nos protominērios carbonäticos, onde parecem ter sido formados a partir de piroxmangita e olivi na. (Fotos 57,58$)$.

Estudos öpticos mostraram tratar-se de um anfibōlio in color, às vezes amarelado e sem nenhum ou com muito pouco pleo croismo. Geminação, polissintētica foi observada em alguns cris tais e medidas dos āngulos entre os eixos öpticos $2 v x$ forneceram valores entre $83^{\circ}$ e $86^{\circ}$.

Dados de microssonda eletrônica são apresentados na Ta bela XV onde se observa a porcentagem em peso do Mgo variando de 19,02 a 20,37; a do MnO de 17,04 a 19,19 e a de Fe0 de 0,53: a 2,64 .

Esses anfibölios podem ser classificados como cummingto nita rica em manganēs ou como uma danemorita rica em magnësio.

Em muitos casos o crescimento dos anfibólios $\bar{e}$ poste rior à formação das principais assemblēias metamörficas, prova velmente como resultado de valor maior de $x_{H_{2}} 0$ dos fluidos dos poros durante uma fase de metamorfismo retrógrado. 
TABELA XIV - ANALISES DE MICROSSONDA DE FLOGOPITAS MANGANESIFERAS DE PROTOMINERIOS DE Mn DE SERRA DO NAVIO

\section{Peso $\%$}

\begin{tabular}{|c|c|c|c|c|c|c|c|c|c|c|}
\hline AMOSTRA NO & & $\mathrm{SiO}_{2}$ & $\mathrm{Al}_{2} \mathrm{O}_{3}$ & $\mathrm{CaO}$ & $\mathrm{MgO}$ & MnO & FeO & $\mathrm{TiO}_{2}$ & $\mathrm{Na}_{2} \mathrm{O}$ & $\mathrm{K}_{2} \mathrm{O}$ \\
\hline$F 12-76-94,8$ & I & 37,48 & 14,06 & - & 18,59 & 3,10 & 9,79 & 0,66 . & 0,16 & 8,83 \\
\hline F12-76-94,8 & II & 37,59 & 13,06 & 0,02 & 18,37 & 2,99 & 9,76 & 0,61 & 0,15 & 9,05 \\
\hline$F 12-76-111,7$ & II I & 40,72 & 13,29 & - & 23,23 & 3,03 & 9,36 & 0,44 & 0,42 & 9,27 \\
\hline$F 12-76-117$ & II & 39,72 & 12,71 & - & 22,25 & 3,43 & 5,45 & 0,76 & 0,12 & 9,46 \\
\hline
\end{tabular}

Nümero de ions com base em 22 oxigēnios

\begin{tabular}{|c|c|c|c|c|c|c|c|c|c|c|}
\hline AMOSTRA NO & & $\mathrm{Si}$ & A 7 & $\mathrm{Ca}$ & $\mathrm{Mg}$ & $M n$ & $\mathrm{Fe}$ & $\mathrm{Ti}$ & $\mathrm{Na}$ & $k$ \\
\hline$F 12-76-94,8$ & I & 5,65 & 2,50 & - & 4,18 & 0,40 & 1,23 & 0,07 & 0,05 & 1,70 \\
\hline$F 12-76-94,8$ & II & 5,71 & 2,34 & - & 4,27 & 0,38 & 1,24 & 0,07 & 0,04 & 1,75 \\
\hline$F \mid 2-76-111,7$ & I I I & 5,89 & 2,27 & - & 5,01 & 0,37 & 0,41 & 0,05 & 0,12 & 1,71 \\
\hline $512-76-117$ & II & 5,86 & 2,21 & - & 4,89 & 0,43 & 0,67 & 0,08 & 0,03 & 1,78 \\
\hline
\end{tabular}


TABELA XV - ANALISES DE MICROSSONDA DE ANFIBÖLIOS DE PROTOMINERIOS DE Mn DE SERRA DO NAVIO

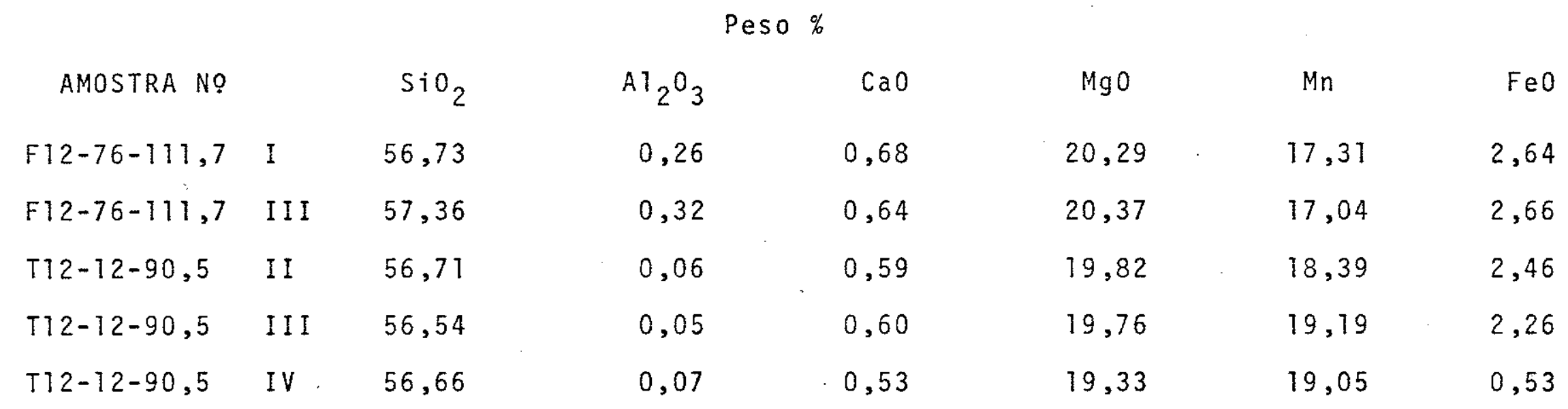

Nümero de ions com base em 23 oxigēnios

\begin{tabular}{|c|c|c|c|c|c|c|c|}
\hline AMOSTRA NO & & $\mathrm{Si}$ & Al & $\mathrm{Ca}$ & $\mathrm{Mg}$ & $M n$ & $\mathrm{Fe}$ \\
\hline$F 12-76-111,7$ & I & 8,07 & 0,04 & 0,10 & 4,30 & 2,08 & 0,31 \\
\hline$F 12-76-111,7$ & I I I & 8,09 & 0,05 & 0,09 & 4,28 & 2,84 & 0,31 \\
\hline T12-12-90,5 & II & 8,05 & 0,01 & 0,09 & 4,20 & 2,21 & 0,29 \\
\hline$T ? 2-12-90,5$ & III & 8,03 & 0.01 & 0,09 & 4,18 & 2,31 & 0,27 \\
\hline T12-12-90,5 & IV. & 8,14 & 0,01 & 0,08 & 4,14 & 2,32 & 0,06 \\
\hline
\end{tabular}


TABELA XVI - DADOS ŌPTICOS DE PI'ROXENŌIDES DE PROTOMINERIOS DE Mn DE SERRA DO NAVIO

\begin{tabular}{|c|c|c|c|c|c|c|}
\hline AMOSTRA NC & & Sinal ōptico & $2 V_{\gamma}$ & $\begin{array}{l}\text { C1 ivagem } \\
(110 \text { NTTO })\end{array}$ & $\gamma \wedge z$ & Mineral \\
\hline$T 12-12-90,5$ & 1 & $\mathrm{~B}^{+}$ & $43,0^{\circ}$ & $95,0^{\circ}$ & $28,0^{\circ}$ & Piroxmangita \\
\hline T12-12-90,5 & 2 & $\mathrm{~B}^{+}$ & $46,0^{\circ}$ & $90,0^{\circ}$ & $39,0^{\circ}$ & Piroxmangita \\
\hline T12-12-90,5 & 3 & $\mathrm{~B}^{+}$ & $48,0^{\circ}$ & $89,0^{\circ}$ & $52,0^{\circ}$ & Piroxmangita \\
\hline$T 12-12-90,5$ & 4 & $B^{+}$ & $39,0^{\circ}$ & $89,0^{\circ}$ & $73,0^{\circ}$ & Piroxmangita \\
\hline$T 12-12-90,5$ & 5 & $\mathrm{~B}^{+}$ & $42,0^{\circ}$ & - & - & Piroxmangita \\
\hline T12-12-90,5 & 6 & $\mathrm{~B}^{+}$ & $40,0^{\circ}$ & $93,0^{\circ}$ & $30,0^{\circ}$ & Piroxmangita \\
\hline média & & & $43,0^{\circ}$ & $91,2^{\circ}$ & $44,4^{\circ}$ & \\
\hline$F 12-76-117$ & 1 & $\mathrm{~B}^{+}$ & $42,0^{\circ}$ & $92,0^{\circ}$ & $53,0^{\circ}$ & Piroxmangita \\
\hline F $12-76-117$ & 2 & $B^{+}$ & $46,0^{\circ}$ & $90,0^{\circ}$ & $40,0^{\circ}$ & Piroxmangita \\
\hline$F 12-76-117$ & 3 & $\mathrm{~B}^{+}$ & $46,0^{\circ}$ & $88,0^{\circ}$ & $39,0^{\circ}$ & Piroxmangita \\
\hline$F 12-76-117$ & 4 & $B^{+}$ & $41,0^{\circ}$ & $91,0^{\circ}$ & $50,0^{\circ}$ & Piroxmangita \\
\hline F12-76-117 & 5 & $\mathrm{~B}^{+}$ & $38,0^{\circ}$ & $91,0^{\circ}$ & $34,0^{\circ}$ & Piroxmangita \\
\hline$F 12-76-177$ & 5 & $\mathrm{~B}^{+}$ & $43,5^{\circ}$ & $86,0^{\circ}$ & $42,0^{\circ}$ & Piroxmangita \\
\hline mëdia & & & $42,8^{\circ}$ & $89,7^{\circ}$ & $43,0^{\circ}$ & \\
\hline
\end{tabular}


TABELA XVII - DADOS OPTICOS DE OLIVINAS DE PROTOMINERIOS DE Mn DE SERRA dO NAYIO

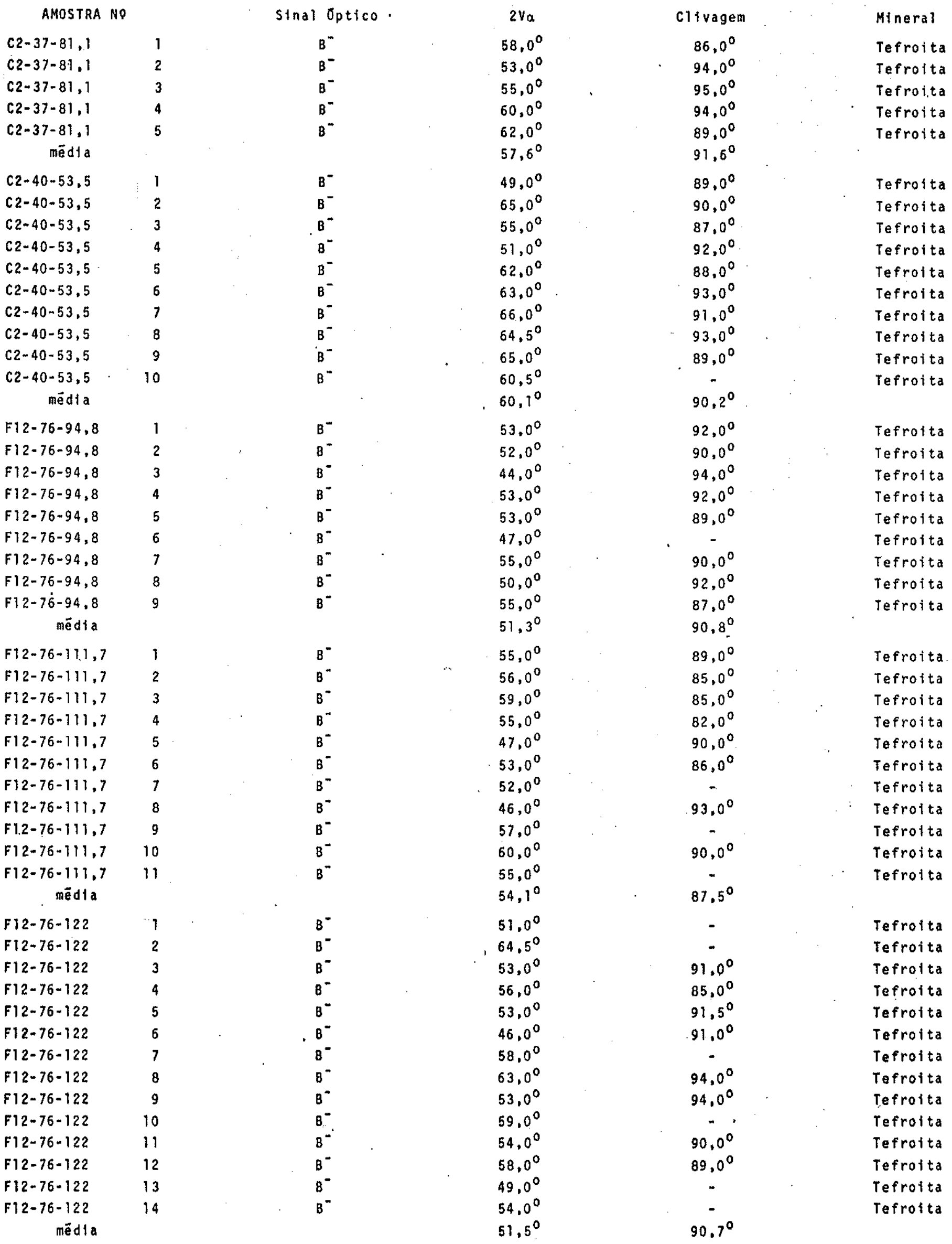




\section{IV - 3- 7 - MINERAIS METALICOS E ACESSORIOS}

A grafita $\vec{e}$ o principal mineral opaco de Serra do $\mathrm{Na}$ vio, encontrando-se sempre disseminada nos protominērios e nas rochas encaixantes, principalmente no xisto de fäcies grafitosa (SCARPELLI, 1973).

A grafita encontra-se tambëm incluída poiquiloblästi camente nos carbonatos, nas granadas, onde às vezes forma zo nas concēntricas e/ou disposições radiais e na cordierita (GIRAR DI et al., 1965) (Fotos 50, 51, 52, 53, 54, 55, 58, 59).

0 minério de Serra do Navio assemelha-se ao de Lafaie te, $M G$, e distingue-se daquele de Buritirama, pela presença de grafita que impede a formação de ōxidos de manganês de alta tem peratura nos protominerios das duas primeiras jazidas.

A pirofanita (Fotos $42,51,52,56,58,59$ ) e a apati ta constituem acessörios comuns em muitas läminas. A primeira apresenta-se tambëm disseminada ou em massas informes de agre gados de cristais vermelhos translücidos e pleocröicos (aniso tropos).

Sulfetos comumente encontrados em veios cortando as encaixantes, como calcopirita e pirrotita, são mais raramente ob servados nos protominērios, pröximos a veios serpentinizados. Alëm dos citados foram encontrados tambëm alabandita e esfaler ta, em raros cristais isolados. 


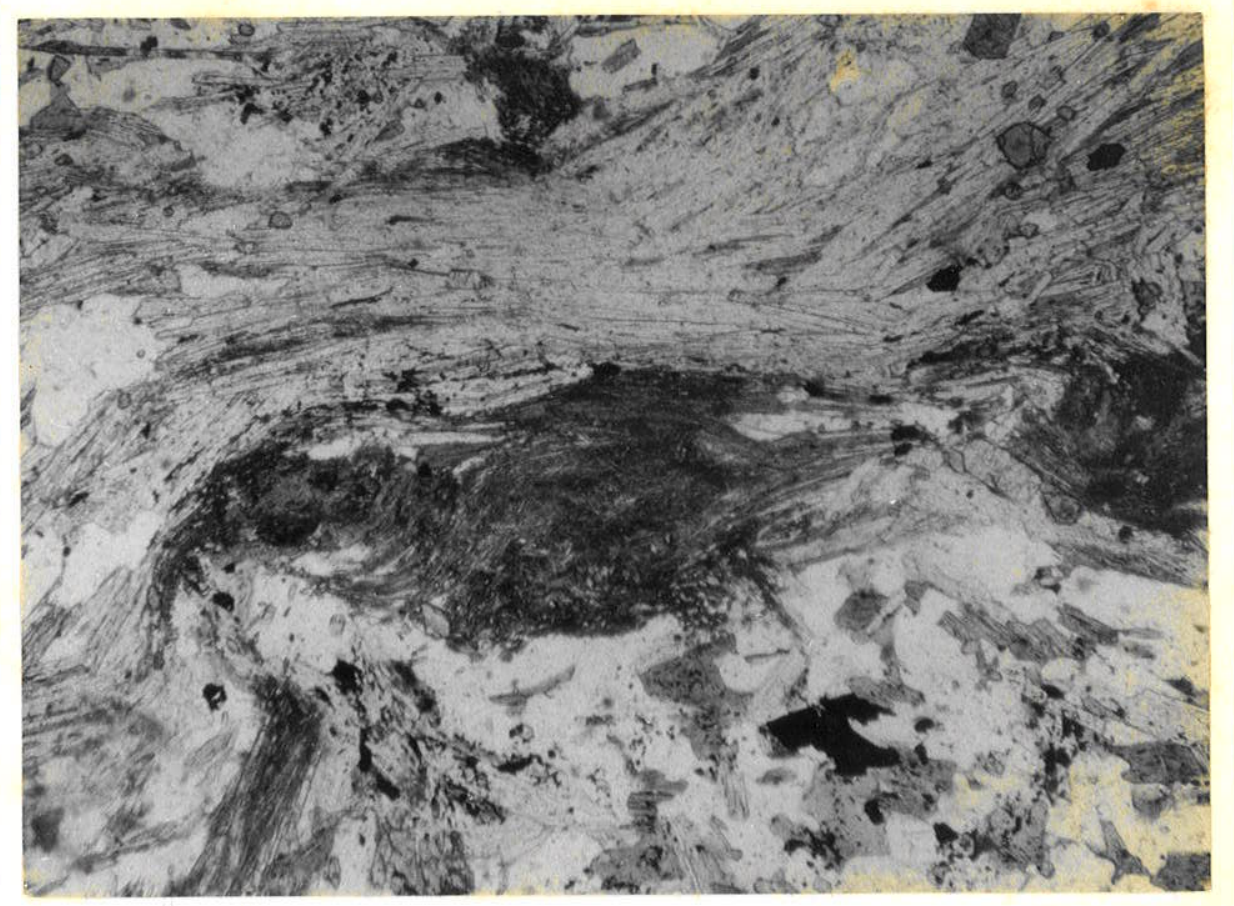

FOTO 33-Rocha metapelítica.Sillimanita-biotita xisto. Rocha de textura lepi doblástica constituída por leitos de sillimanita fibrosa (fibrolita) dis ś cordantes de biotitas mais novas, ao lado de muscovita, quartzo e plagió clásio. Amostra C2-37-134m. N. descruzados, X 35 .

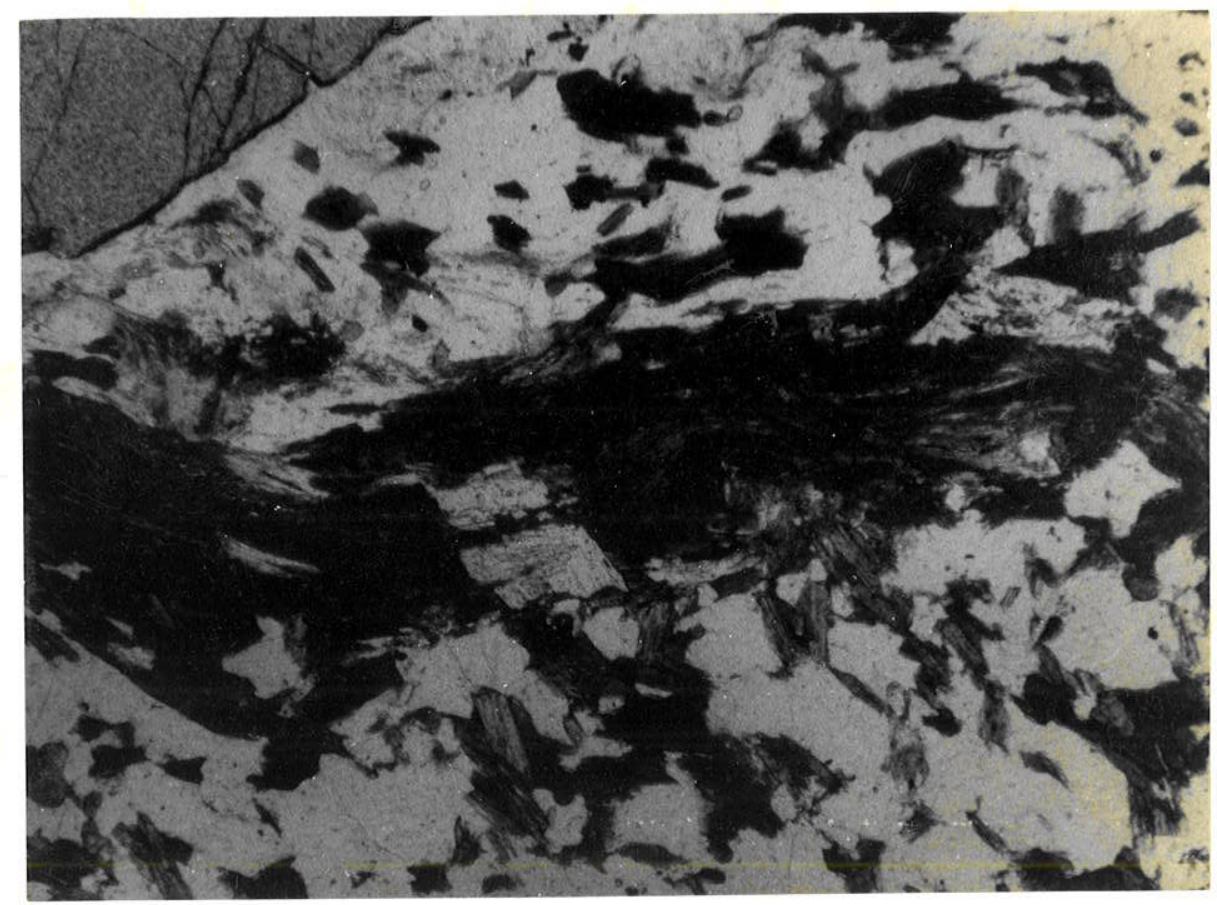

FOTO 34-Rocha metapelîtica. Sillimanita - granada xisto. Textura lepidoblás tica com porfiroblastos de granada. Associação de quartzo, biotita, grana da (porfiroblástica) e sillimanita fibrosa (fibrolita). Amostra C2-37-120m. N. descruzados, X 35 . 


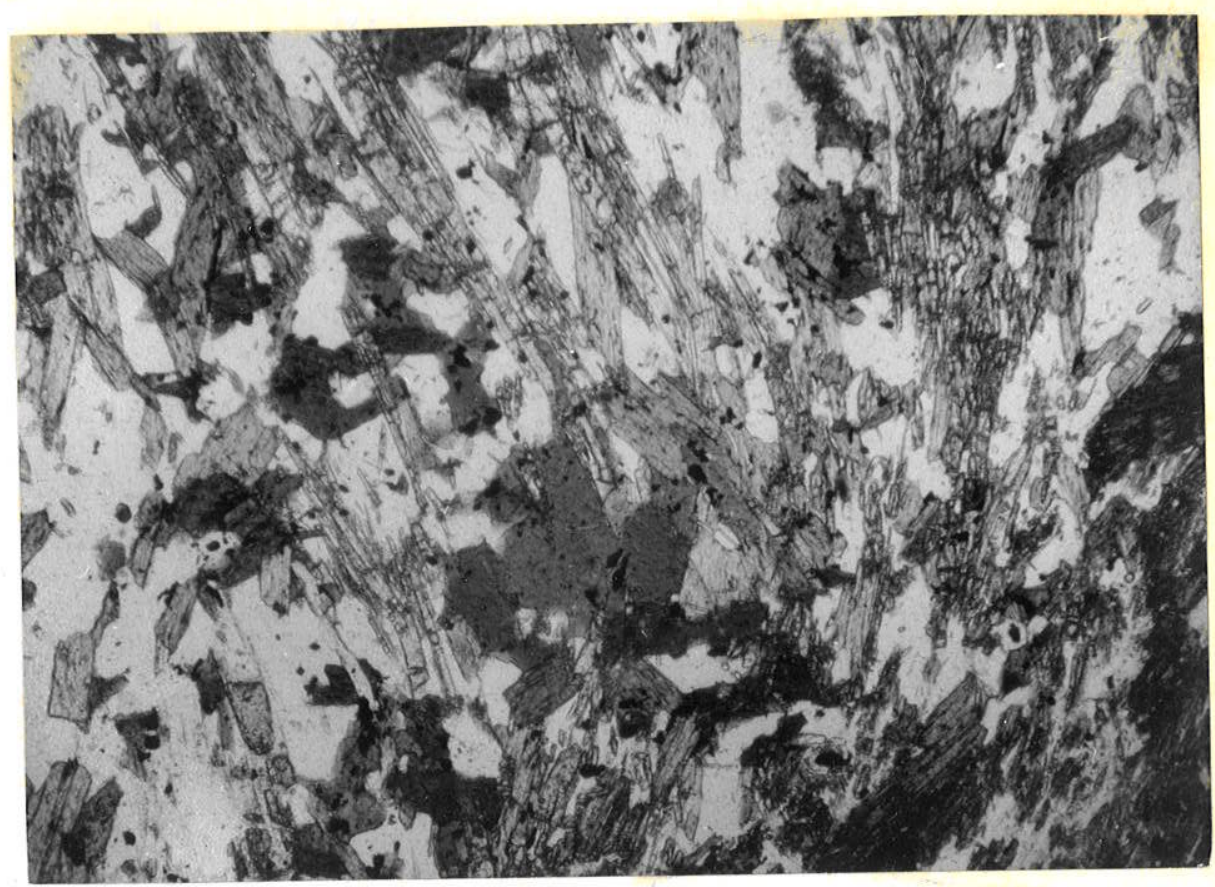

FоTо 35-Rocha metapelítica. Sillimanita-granada xisto. Sillimanita fibrosa orientada (fibrolita) ocorre ao lado de quartzo, biotita e pequena quantidade de muscovita. Em alguns casos observa-se a sillimanita transformando- se em biotita. Textura lepidoblástica. Amostra C2-37-120m. N. descruzados, X 35 .

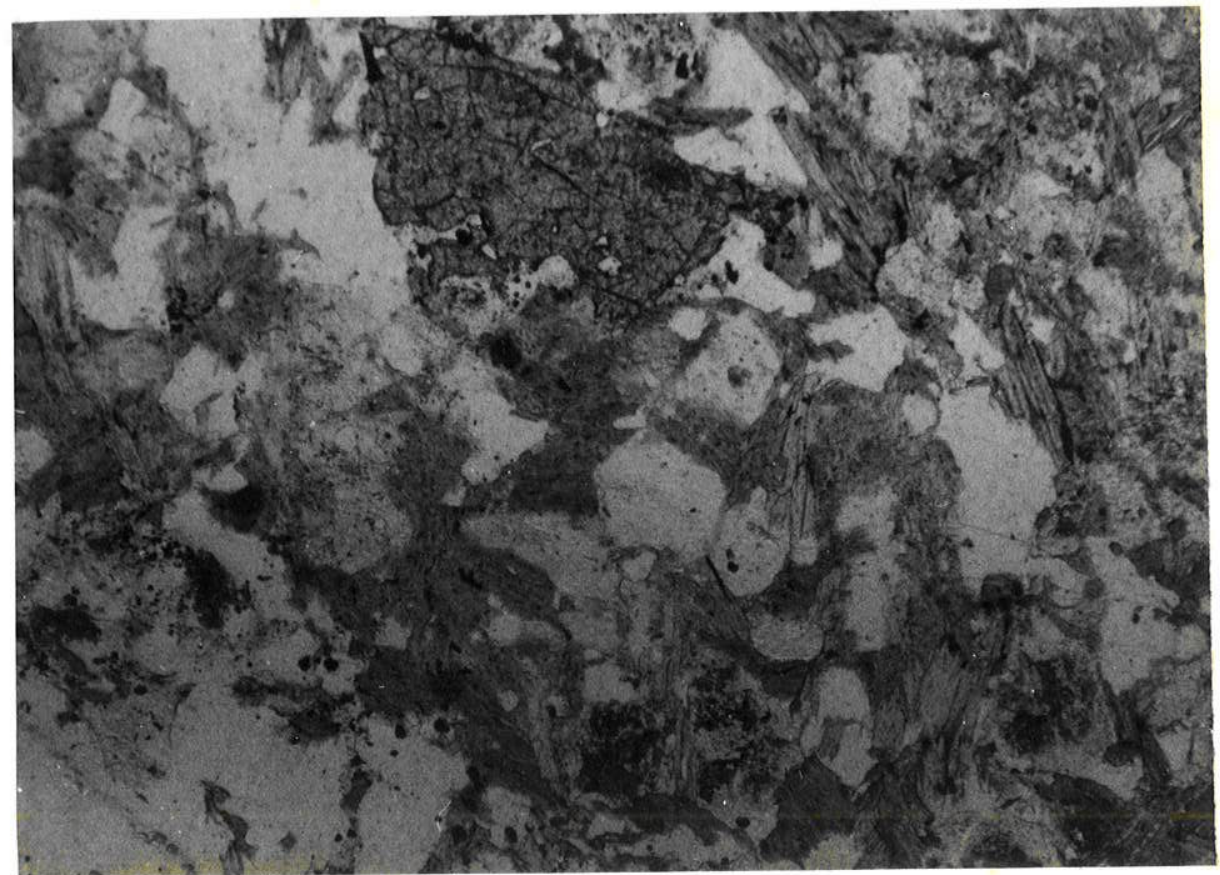

FOTO 36-Rocha metapelítica.Sillimanita-granada-biotita xisto com cordierita. Rocha de textura lepidoblástica com porfiroblastos de granada que se encon tra associada a cordierita, quartzo e biotita orientada. A cordierita se apresenta pouco alterada. Amostra C2-37-99m. N. descruzados, X 35 . 


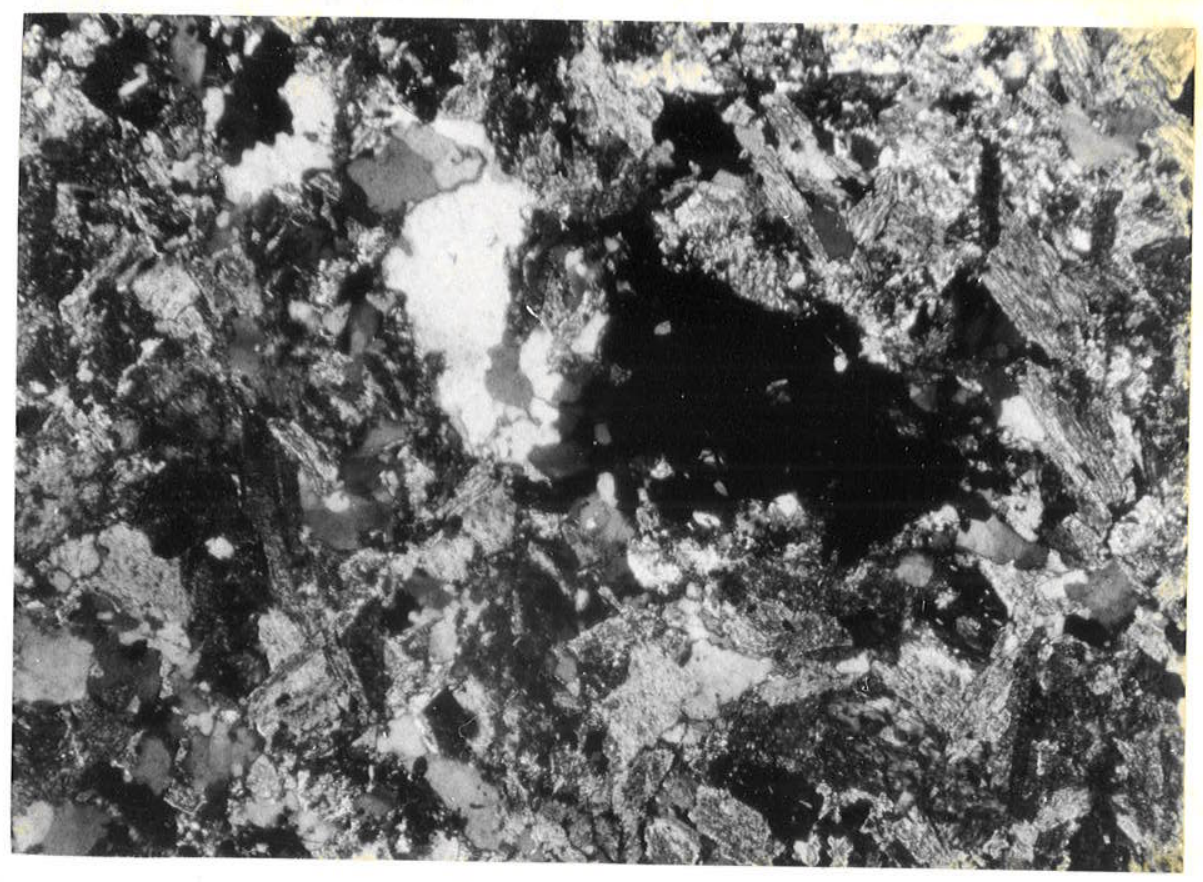

FOTO 37-Idem, foto anterior. Amostra C2-37-99m. N. cruzados, X 35.

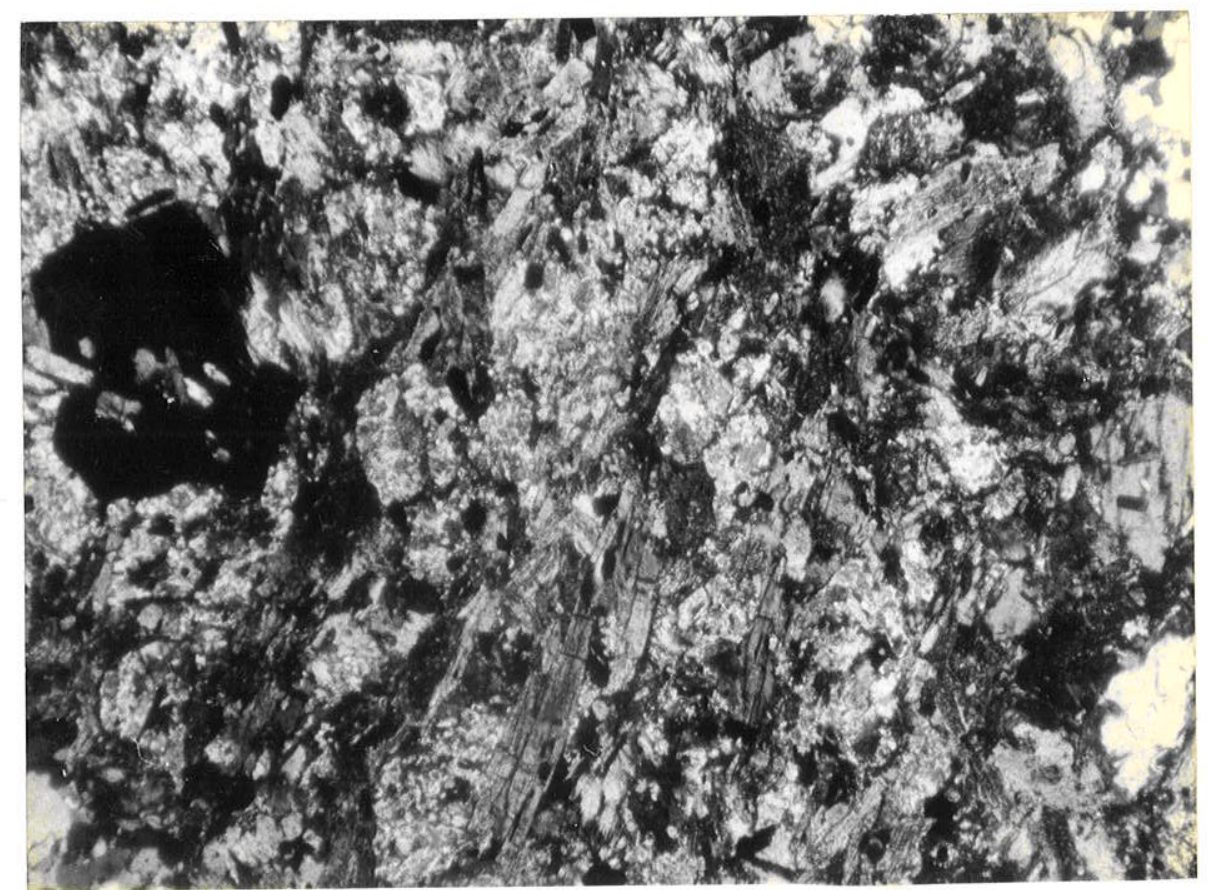

FOTO 38-Rocha metapelîtica.Sillimanita-granada-biotita xisto com cordierita. Porfiroblasto de granada (extinto) com inclusões poiquilíticas de andalusi ta. Outros minerais associados são:sillimanita e biotita orientadas, cor dierita com alguma alteração e opacos. Textura lepidoblástica. Anostra C2-37-99m. N. cruzados, X 35. 


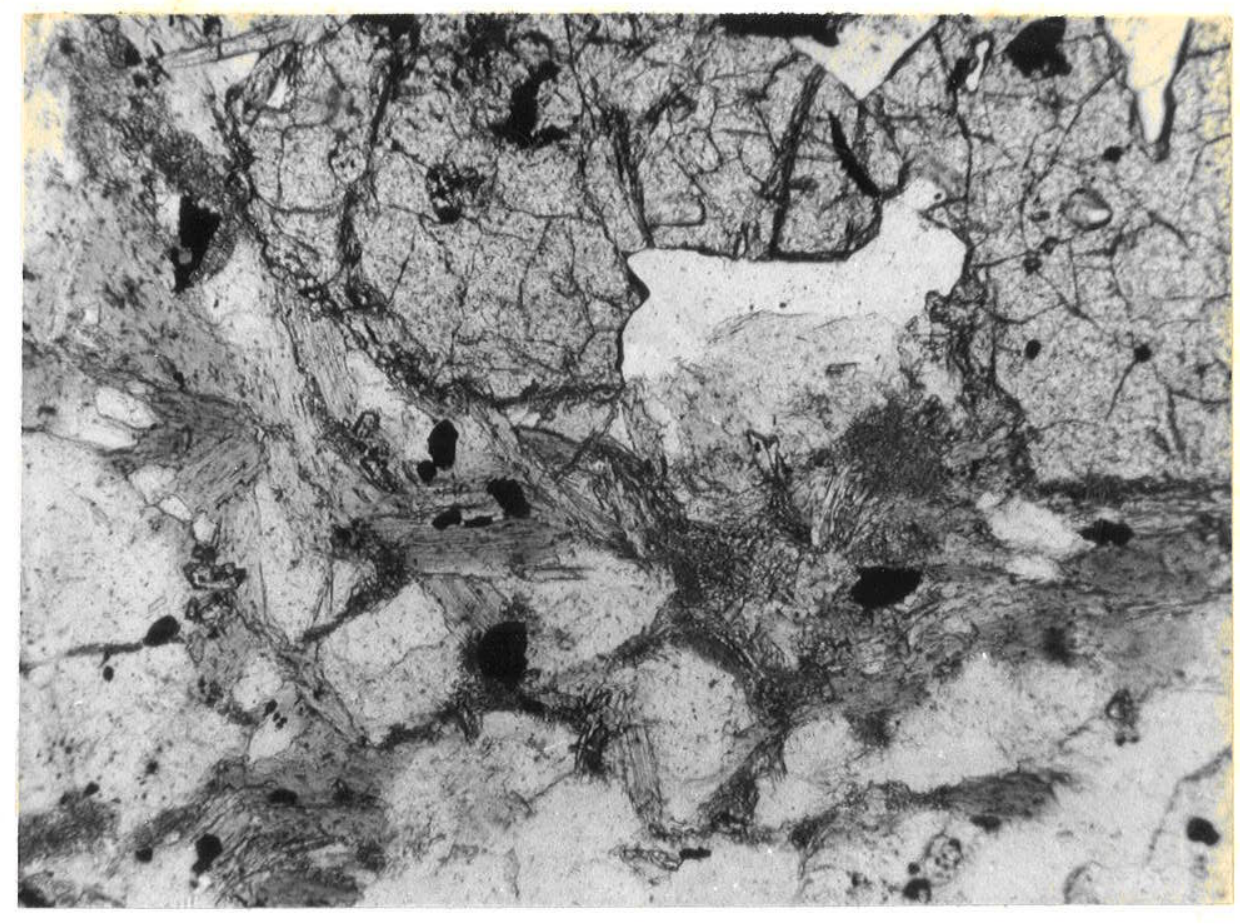

FOTO 39-Rocha metapelîtica.Sillimanita-granada-biotita xisto com cordierita. Granada porfiroblästica encontra-se associada à cordierita, biotita, andalusita, sillimanita, quartzo e opacos. A granada possui inclusões poiquilí ticas de quartzo e opacos. Andalusita transformando-se em sillimanita. Tex tura lepidoblástica. Amostra C2-37-99m. N. descruzados, X 88.

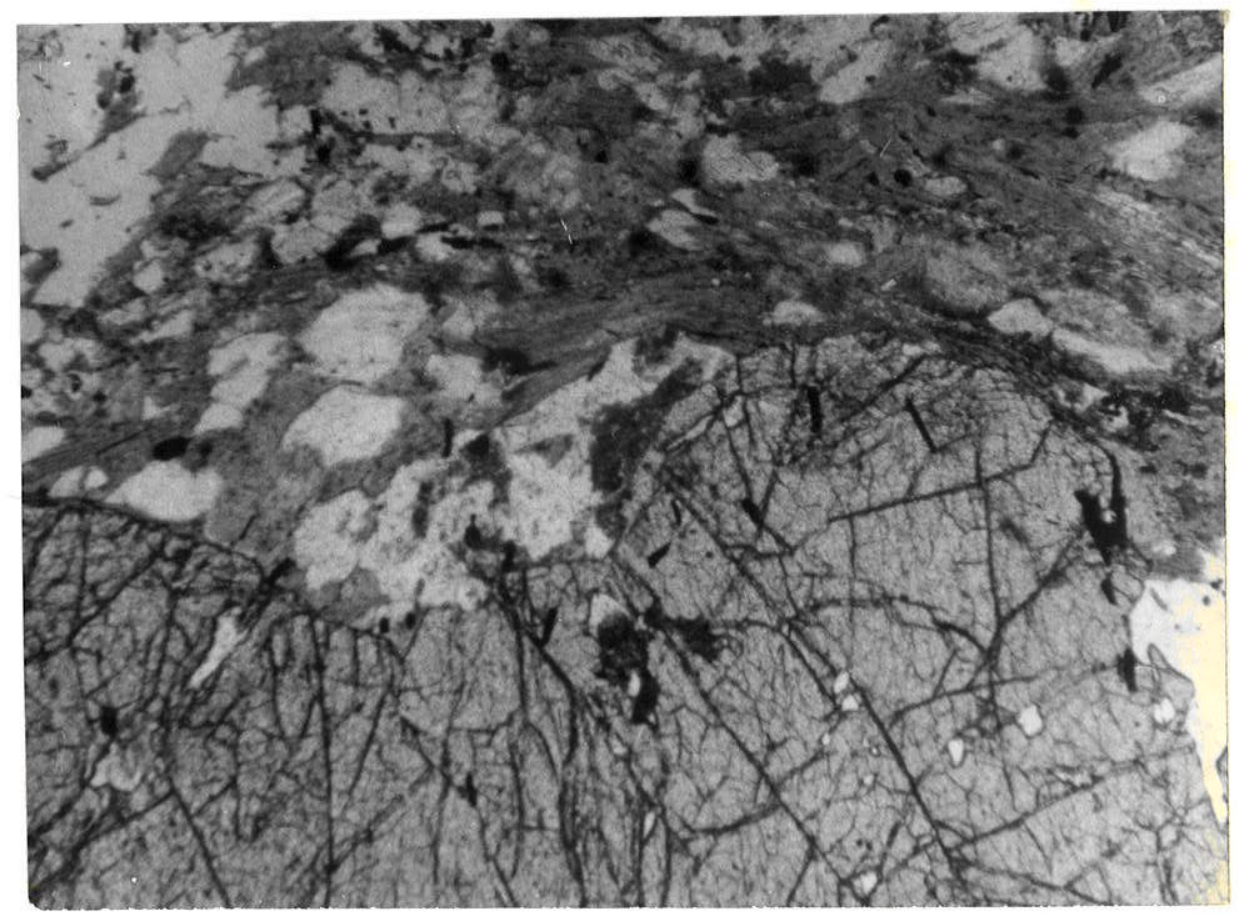

FOTO 40-Rocha metapelítica. Sillimanita-granada-biotita xisto com cordierita. Detalhe onde é observado um macrocristal de granada com inclusões poiquilíticas de andalusita e opacos. Associados à granada, encontramos cristais de sillimanita e biotita orientados, além de andalusita. A andalusita é obser vada transformando-se em sillimanita e esta em biotita. Amostra C2-37-99 m. N. descruzados, X 225 . 


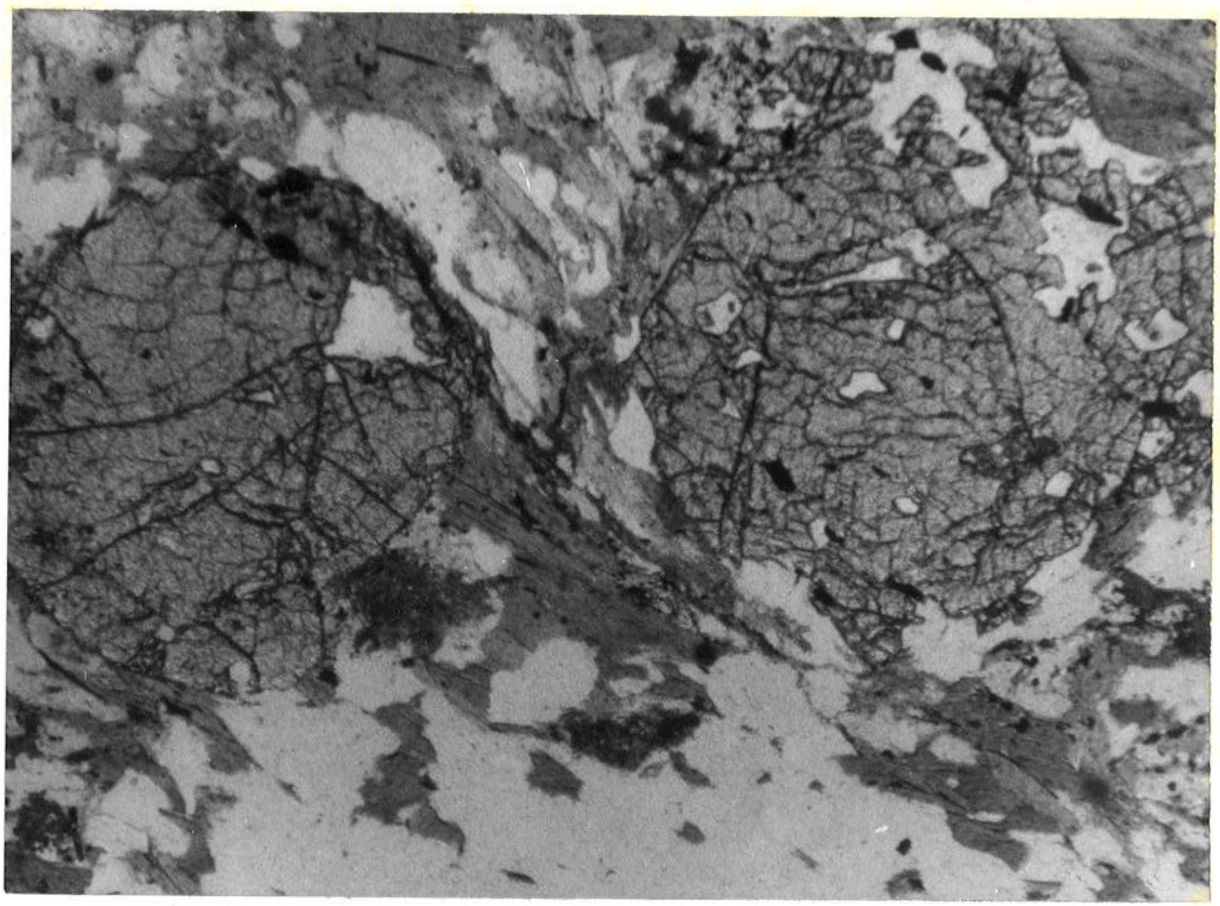

FOTO 41-Rocha metapelítica. Sillimanita-granada-biotita xisto com cordierita. Associação de granada, andalusita, sillimanita, biotita e quartzo. Porfiroblastos de granada com inclusões de andalusita. A andalusita permanece in tacta no interior das granadas, transformando-se, externamente, em sillimanita. A transformação de sillimanita em biotita é também observada. Biotitas posteriores são vistas em torno das granadas. Amostra C2-37-99m. N.descruza dos. X 35.

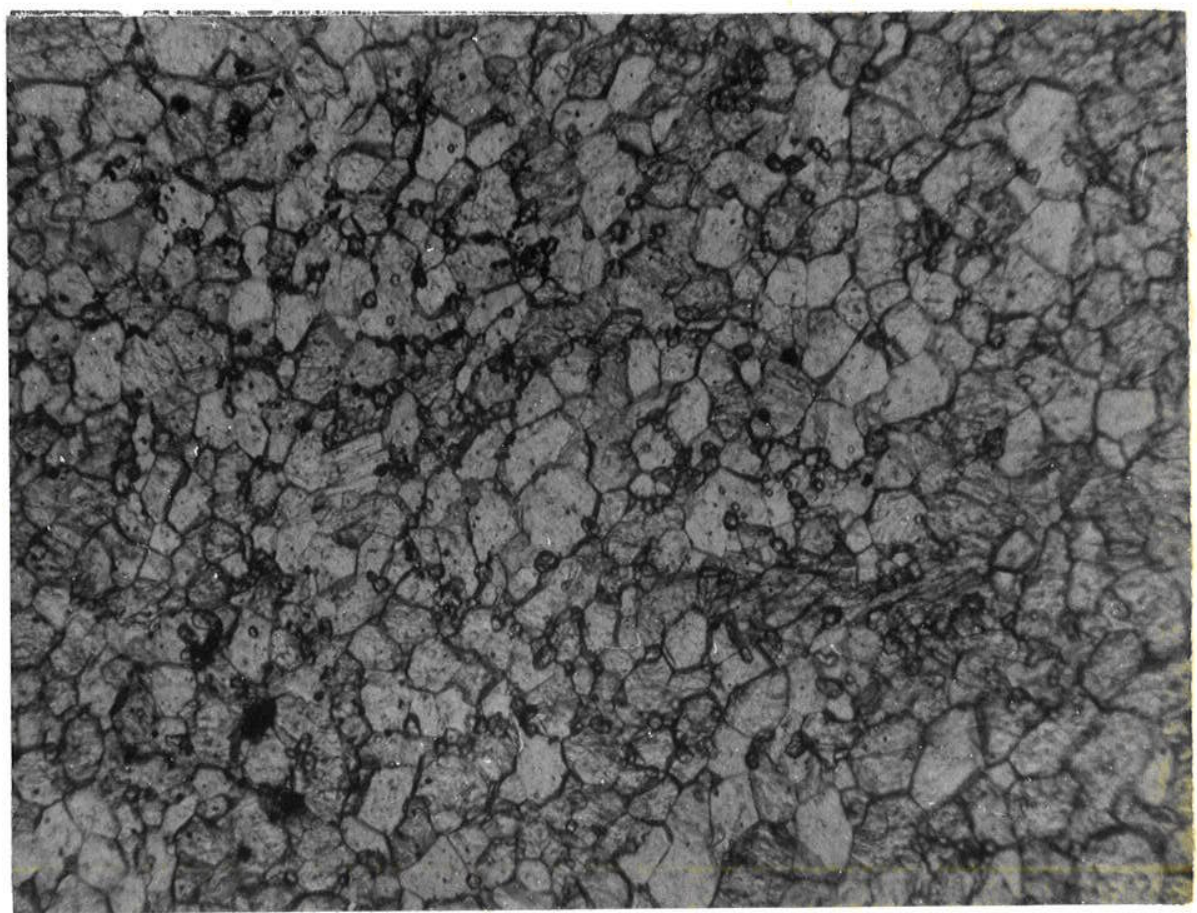

FOTO 42-Protominério carbonático de manganês. Märmore manganesífero. Carbona tos (Ca-kutnahorita), de granulação fina e textura em mosáico, con inclū sões de granadas (espessartitas) mais finas. Textura granoblástica. Amostra C2-37-81m. N. descruzados, X 88 . 


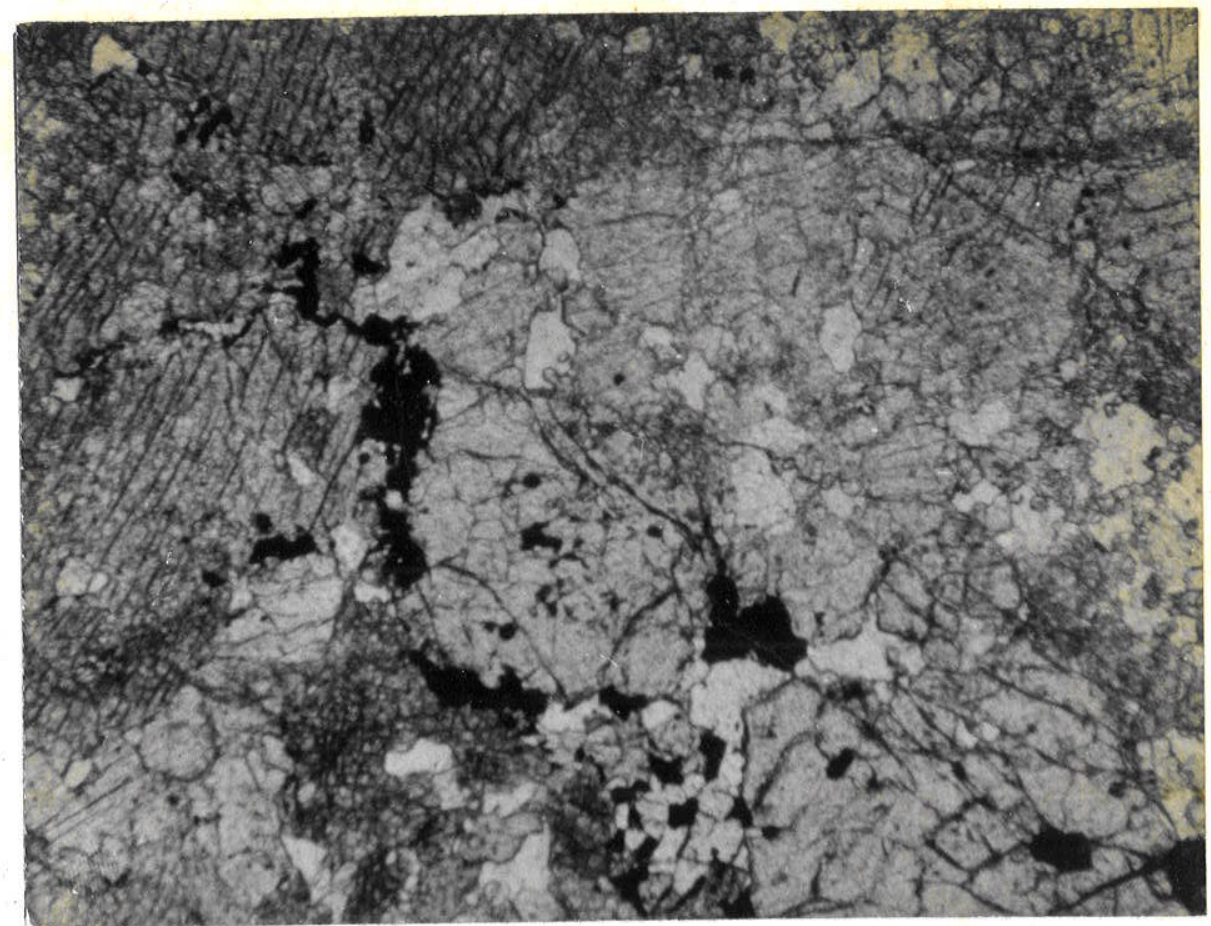

Foto 43-Protominério carbonático de manganês. Mārmore manganesífero. Porção da lâmina onde ocorrem porfiroblastos de piroxenóides (rodonita) e de olivina (tefroita) ambos com inclusões poiquilíticas de carbonato e granada.As sociados a esses minerais ocorrem carbonatc (Ca-kutnahorita), granada(espes sartita), grafita e pirofanita com textura granoblástica. Amostra C2-37-81m N. descruzados, X 35 .

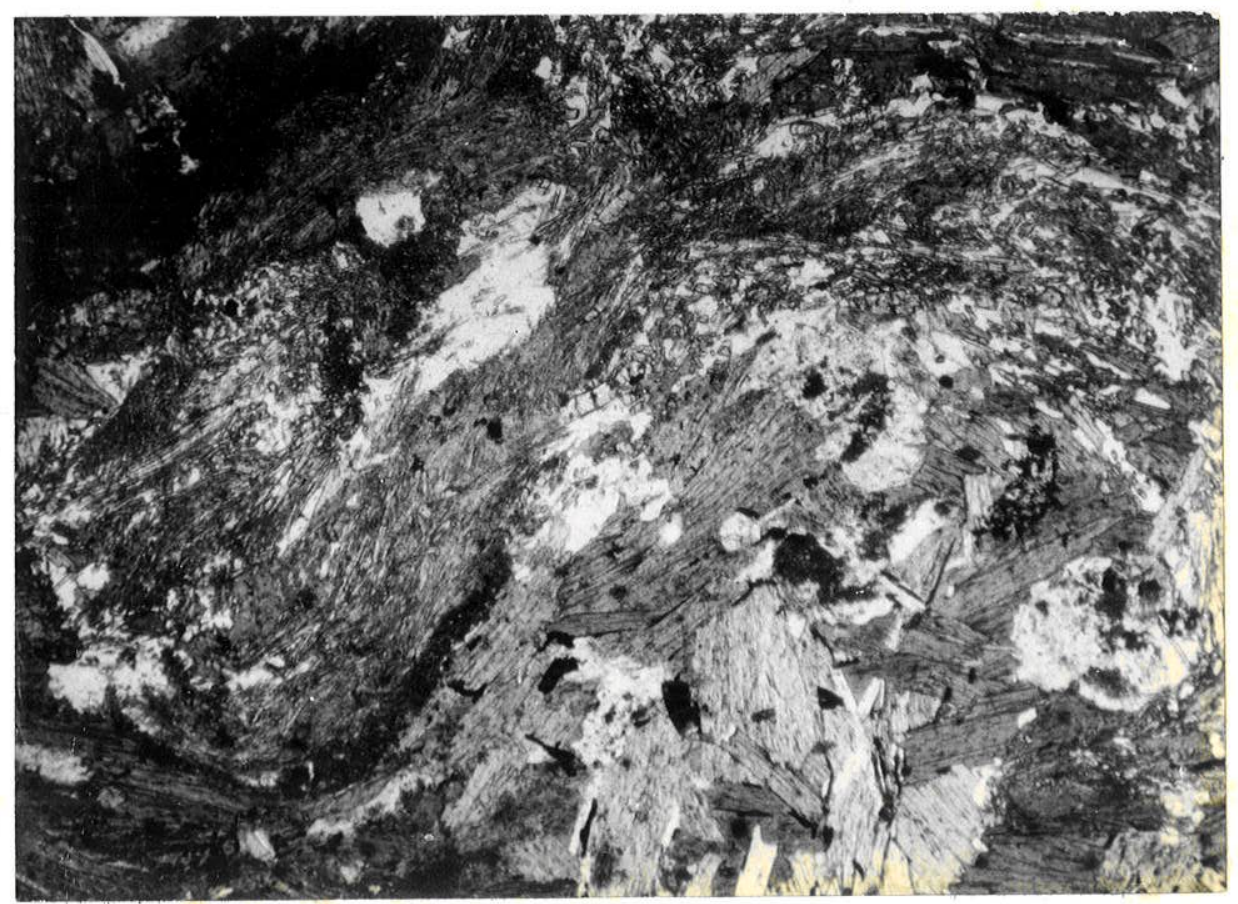

FOTO 44-Rocha metapelïtica.Sillimanita-granáda xisto-Associação de granada, sillimanita, biotita, quartzo, plagioclásic e andalusita. Observa-se trans formação de sillimanita em biotita. Crenulação salientada pela orientaçăo de sillimanita (fibrolita) e biotita. Textura lepidoblástica. Amostra C2$-40-84 \mathrm{~m}$. N. descruzados, X 35 . 


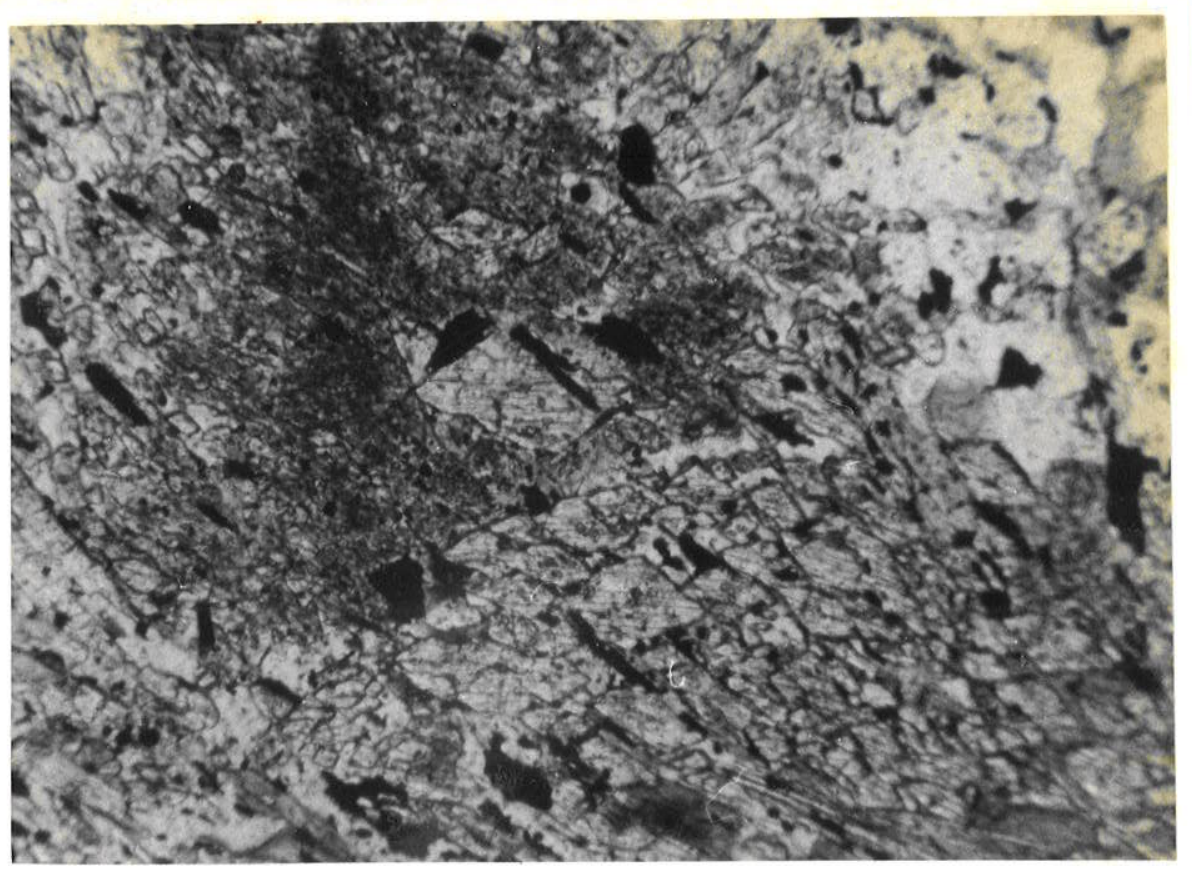

FOTO 45-Rocha metapelîtica.Sillimanita-biotita xisto. Associação de sillima nita, andalusita, quartzo, biotita e opacos. Agregados de andalusita trans formando-se em sillimanita da qual são observados ora cortes paralelos à secção 100, (prismas), ora cortes paralelos à secção 001 (1osangos). Textu ra lepidob1ástica. Amostra C2-40-66m. N.descruzados, X 88.

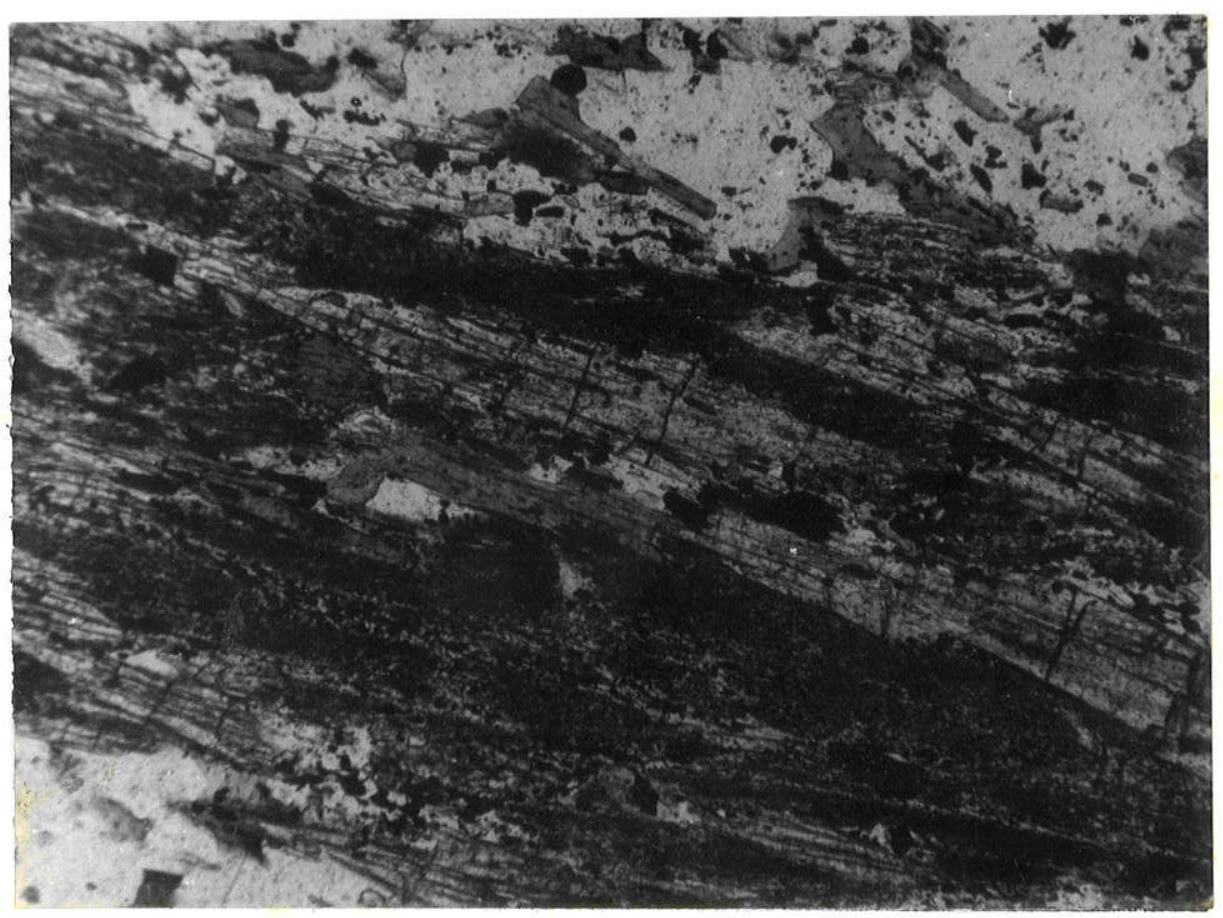

FOTO 46-Rocha metapelítica. Sillimanita-granada xisto com cordierita. Porção da lâmina onde ocorrem macrocristais prismáticos de sillimanita orientada, às vezes transformando-se em biotita, ao lado de quartzo, cordierita e opa cos. Textura lepidoblástica. Amostra C2-40-66m. N.descruzados, X 35 . 


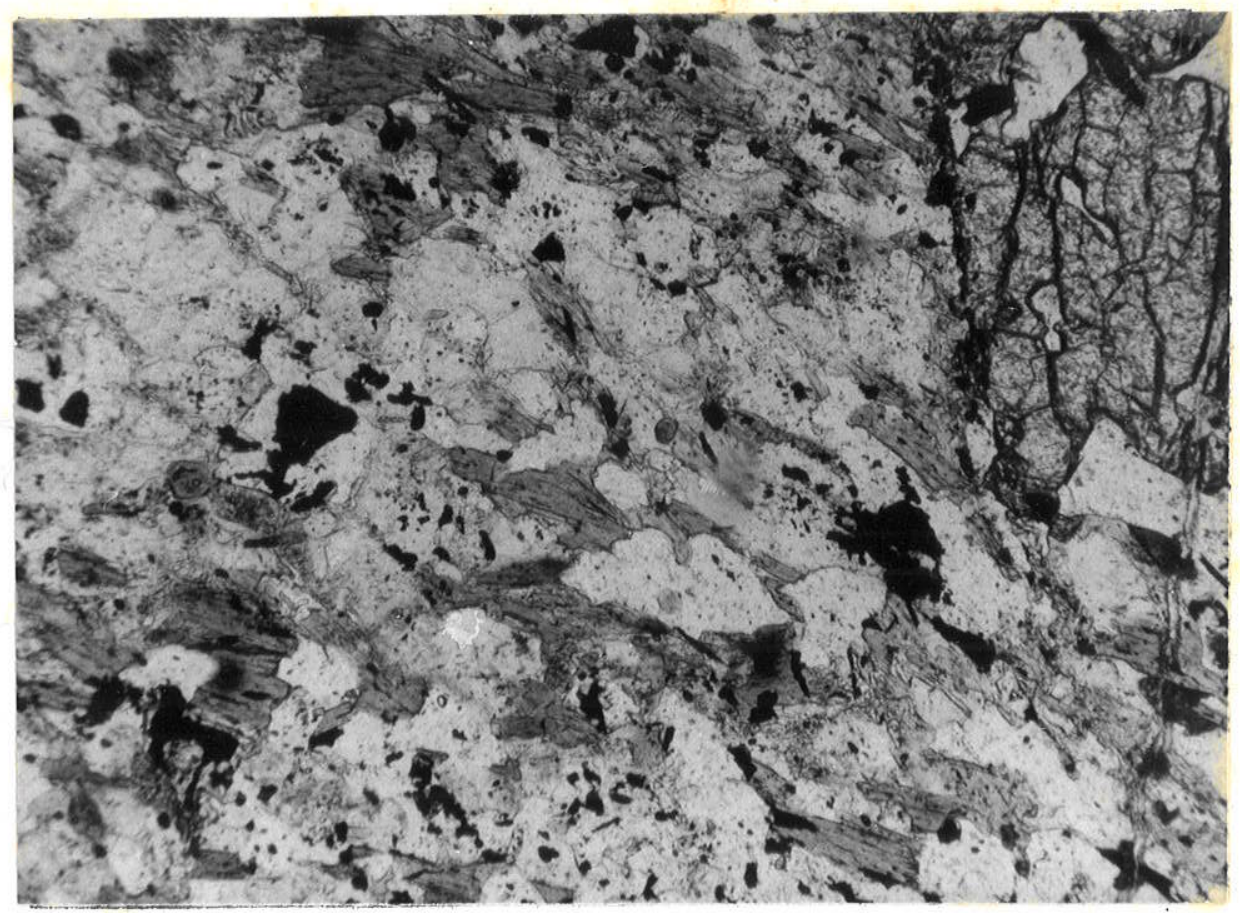

$-93-$

FOTO 47-Rocha metapelítica. Sillimanita-granada xisto com cordierita. Asso ciação de cordierita, granada, quartzo, biotita e opacos. A granada possüi inclusões poiquilíticas de quartzo. Textura lepidoblástica dada por biotitas orientadas. Amostra C2-40-66m. N. descruzados, X 88.

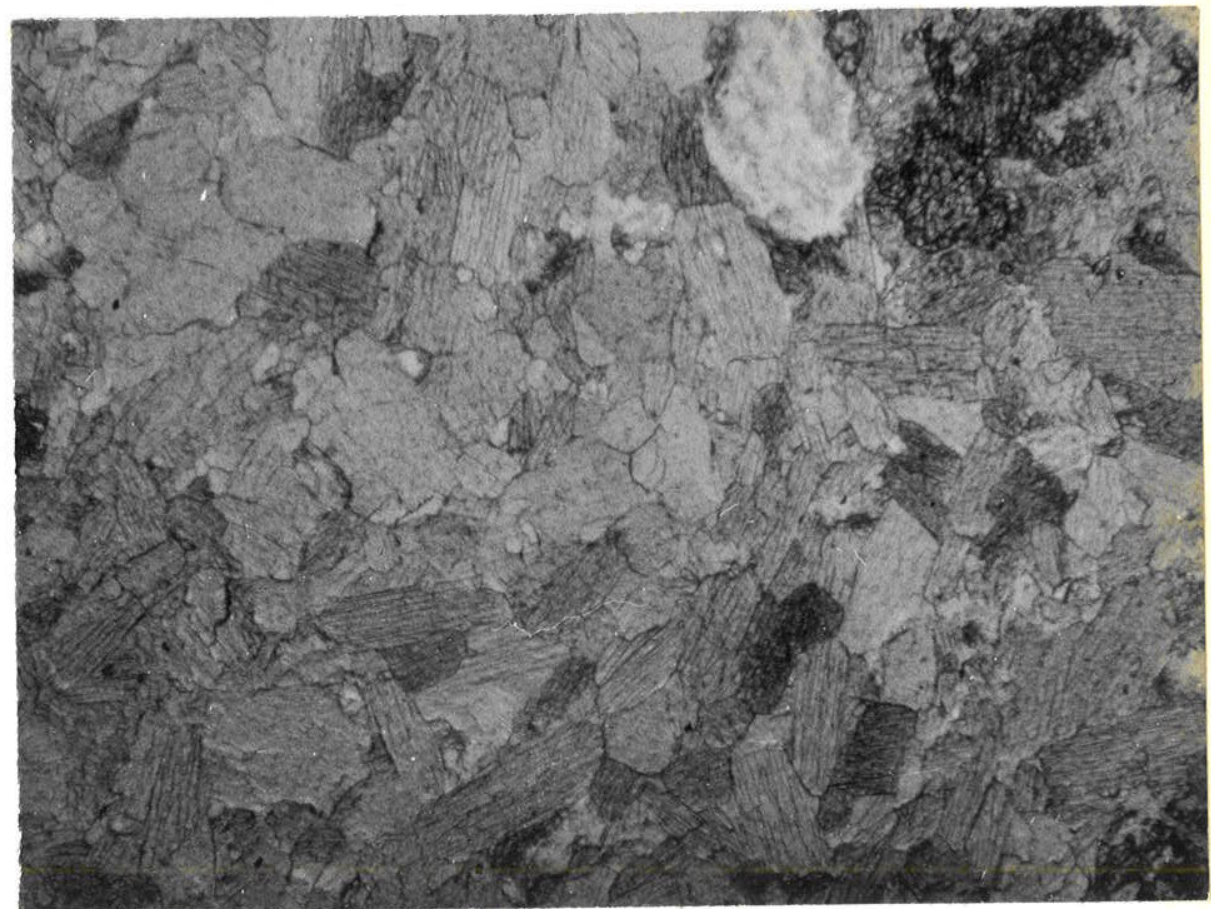

FOTO 48-Rocha calcossilicática. Rocha de textura granoblästica e granulação relativamente uniforme constituída por calcita, diopsídio, tremolita e quartzo. Amostra C2-40-72m. N. descruzados, X 35 . 


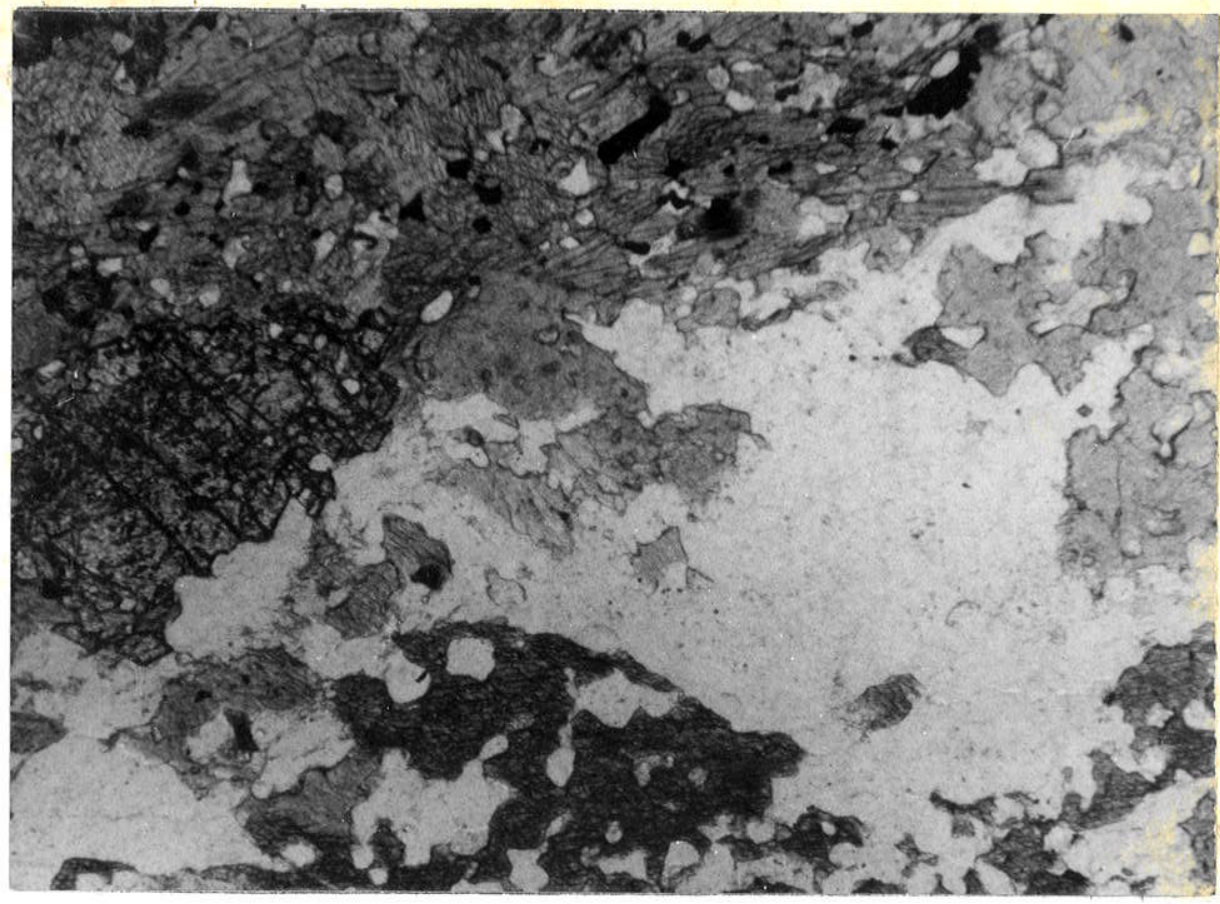

FOTO 49-Rocha calcossilicática. Parte da lâmina onde aparece granada porfiro blástica associada a calcita, tremolita, quartzo e diopsídio. Textura granoblästica. Amostra C2-40-72m. N. descruzados, X 35 .

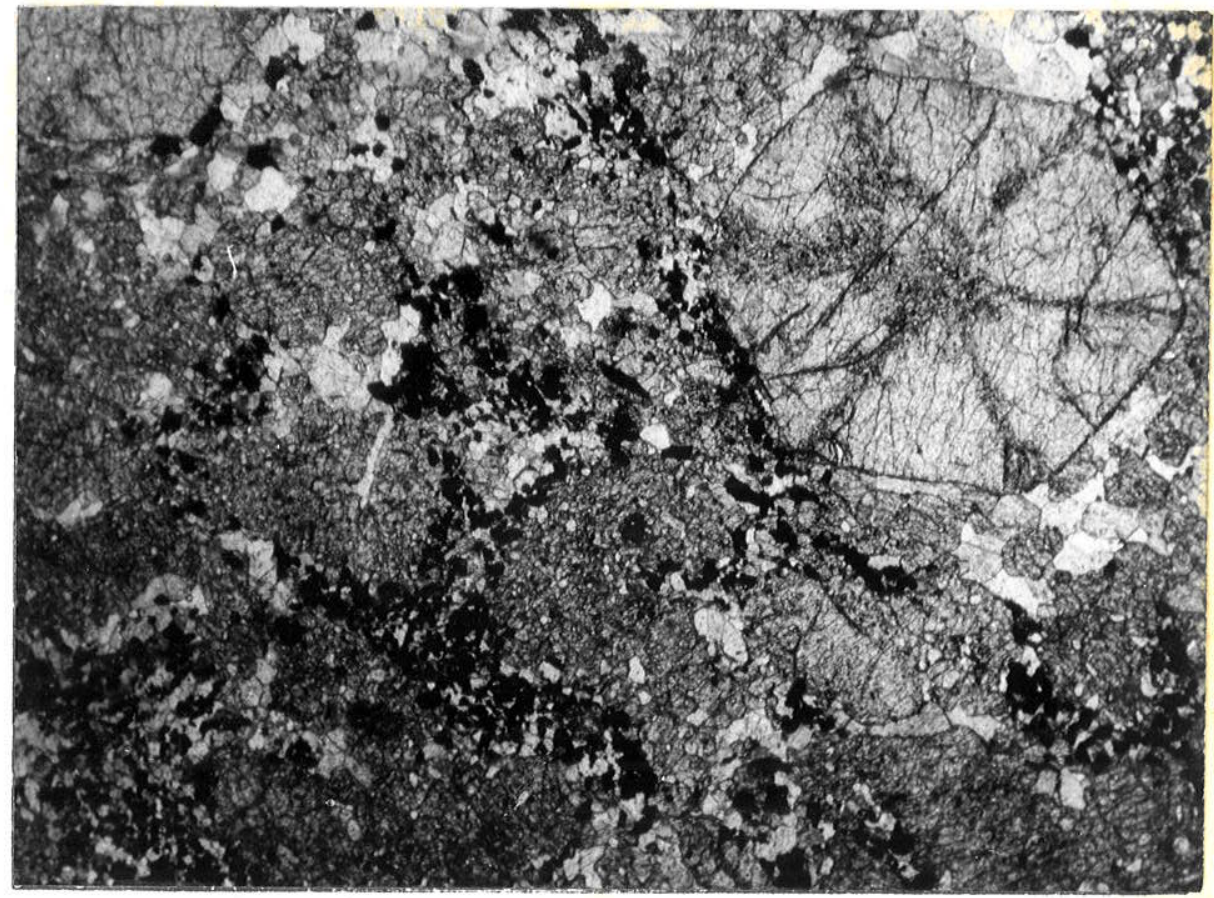

FOTO 50-Protominério carbonático de manganês. Tefroita märmore com espessar tita. Marmore de textura granoblástica com porfiroblastos de espessartita e tefroita. Tefroita poiquiloblástica, com inclusões dé carbonato e grafi ta, associada a carbonato (Ca-kutnahorita), granada (espessartita) e opa cos (grafita e pirofanita). A espessartita contém inclusões radiais de car bonato e grafita. Amostra C2-40-53,5m. N. descruzados, X 35 . 


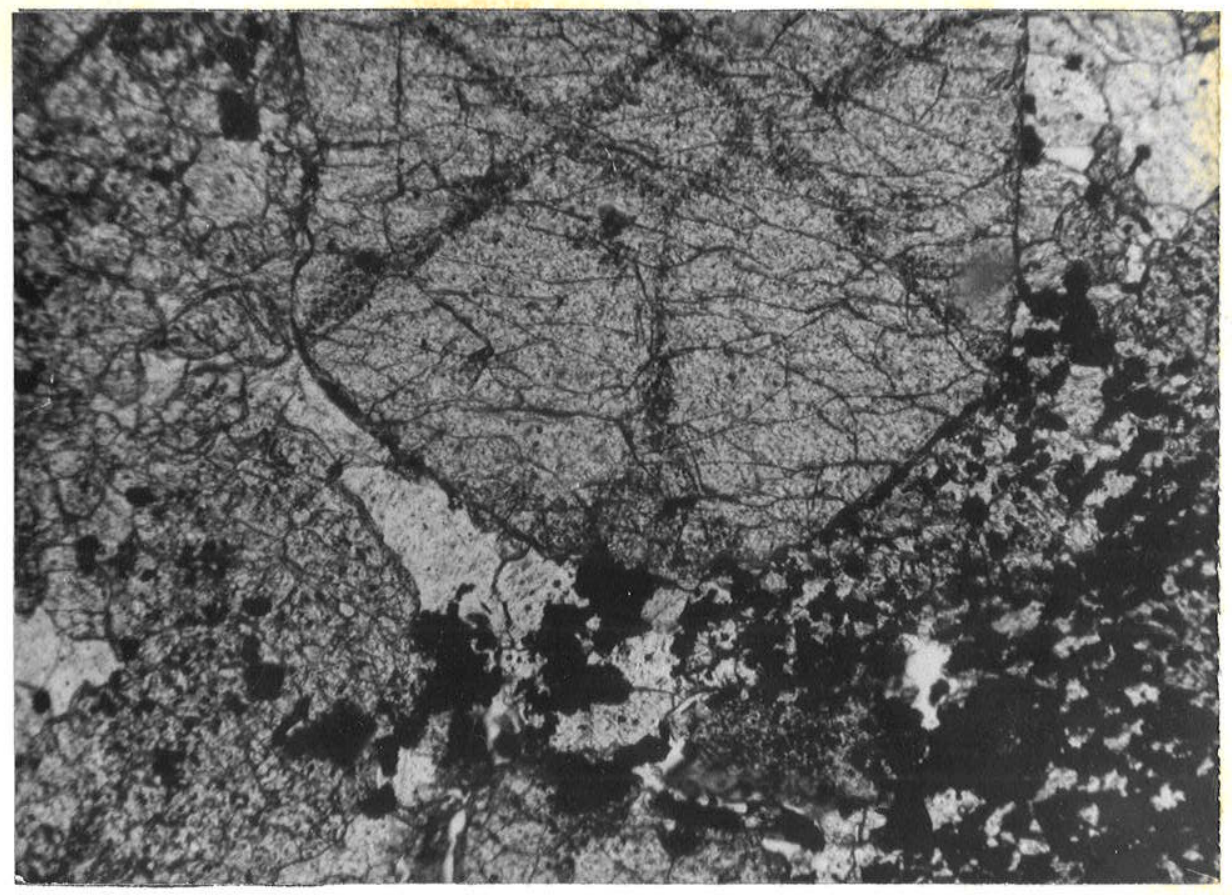

FOTO 51-Protominērio carbonático de manganês. Tefroita märmore com espessạr tita. Porfiroblastos de granada (espessartita) e olivina (tefroita) associa dos a carbonato (Ca-kutnoharita), grafita e pirofanita. A espessartita pos sui inclusões radiais de carbonato fino e grafita; a tefroita inclui carbō nato, grafita e pirofanita.Amostra C2-40-53,5m.N.descruzados, X 88 .

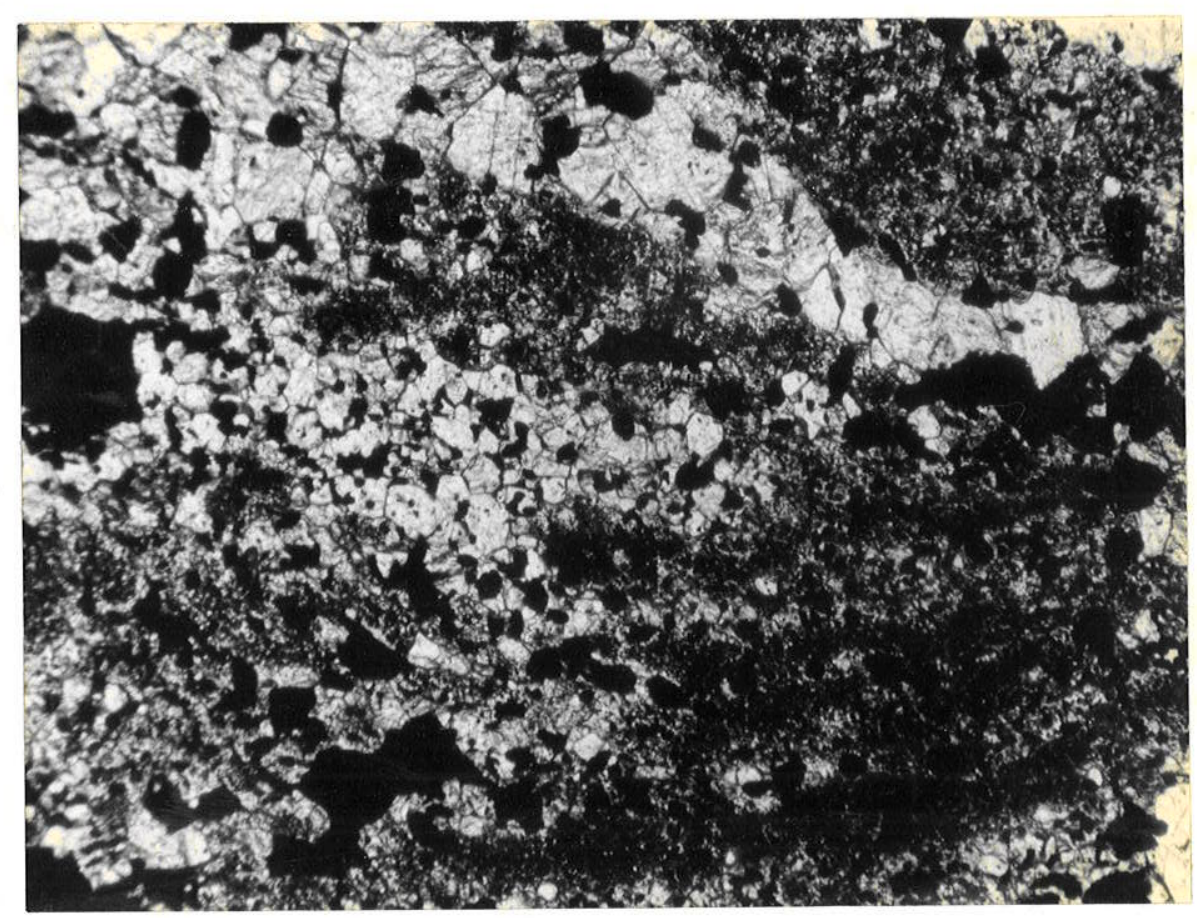

FOTO 52-Protominērio carbonático de manganês. Tefroita märmore. Associação de carbonato (Ca-kutnahorita), olivina (tefroita), grafita, pirofanita e sulfetos. A grafita aparece finamente disseminada nas olivinas posfiroblás ticas. O carbonato apresenta textura granoblástica em mosáico, possuindo em certas faixas granulação maior. Amostra C2-40-48,5m. N.descruzados, X 88 . 


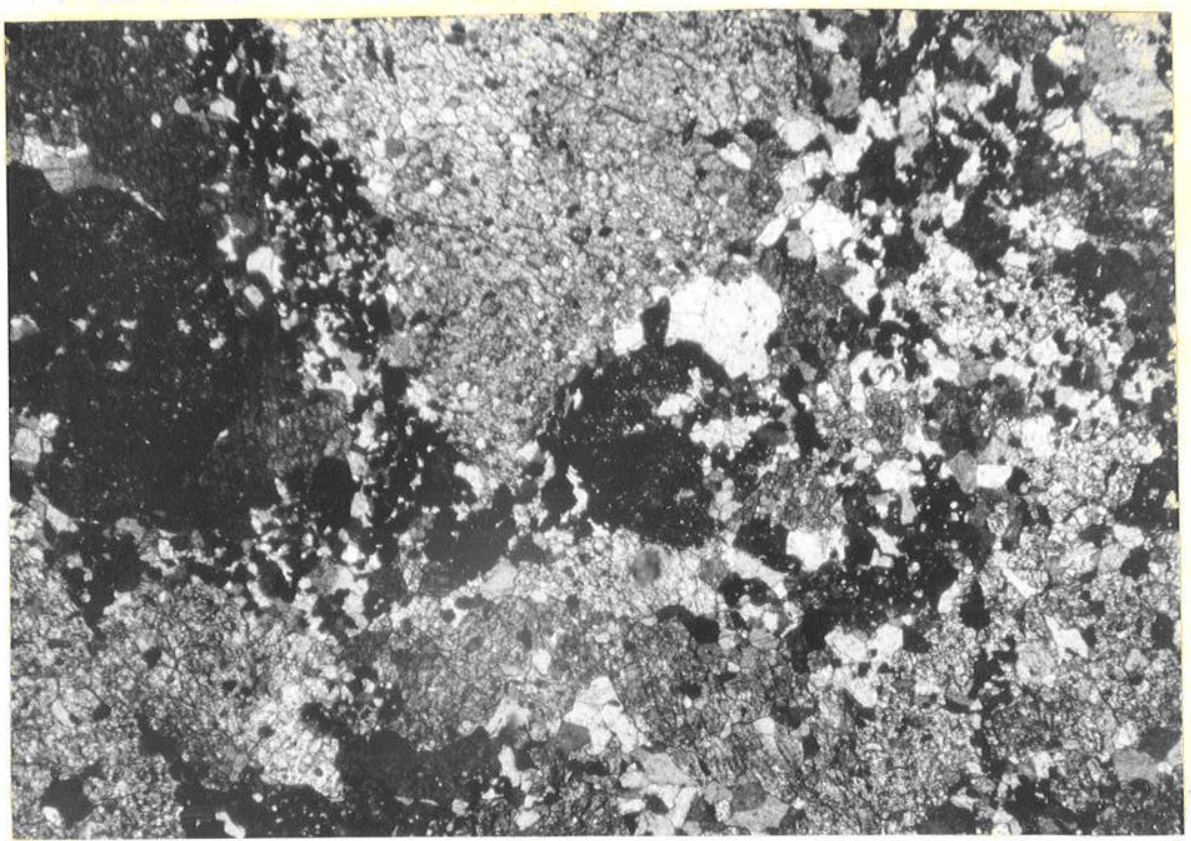

FOTO 53-Protominério carbonātico de manganês. Tefroita mármore com espessar tita. Associação de tefroita, carbonato (Ca-kutnahorita), granada (espes sartita), grafita e pirofanita. As olivinas e as granadas, são porfiroblás ticas e possuem inclusões de carbonato e grafita. Amostra C2-40-53,5m, N, cruzados, X 35 .

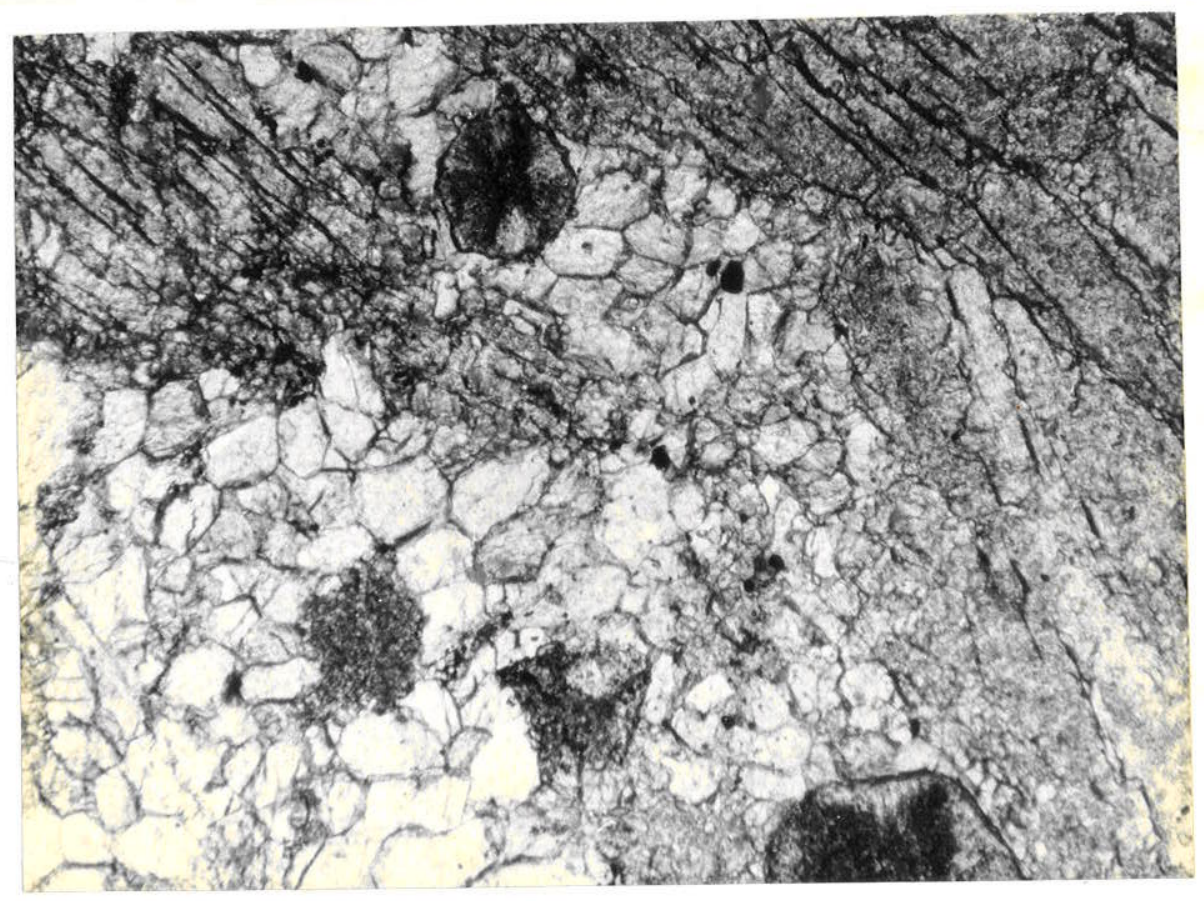

FOTO 54-Protominério carbonático de manganês. Carbonato (Ca-rodocrosita) com textura em mosäico associado a granada (espessartita), manganofilita e pi roxmangita porfiroblástica com inclusões de carbonato. A granada possuí muita inclusão de grafita e de carbonatos finos disseminados. Amostra:F12$-76-91 \mathrm{~m}$. N. descruzados, X 35 . 


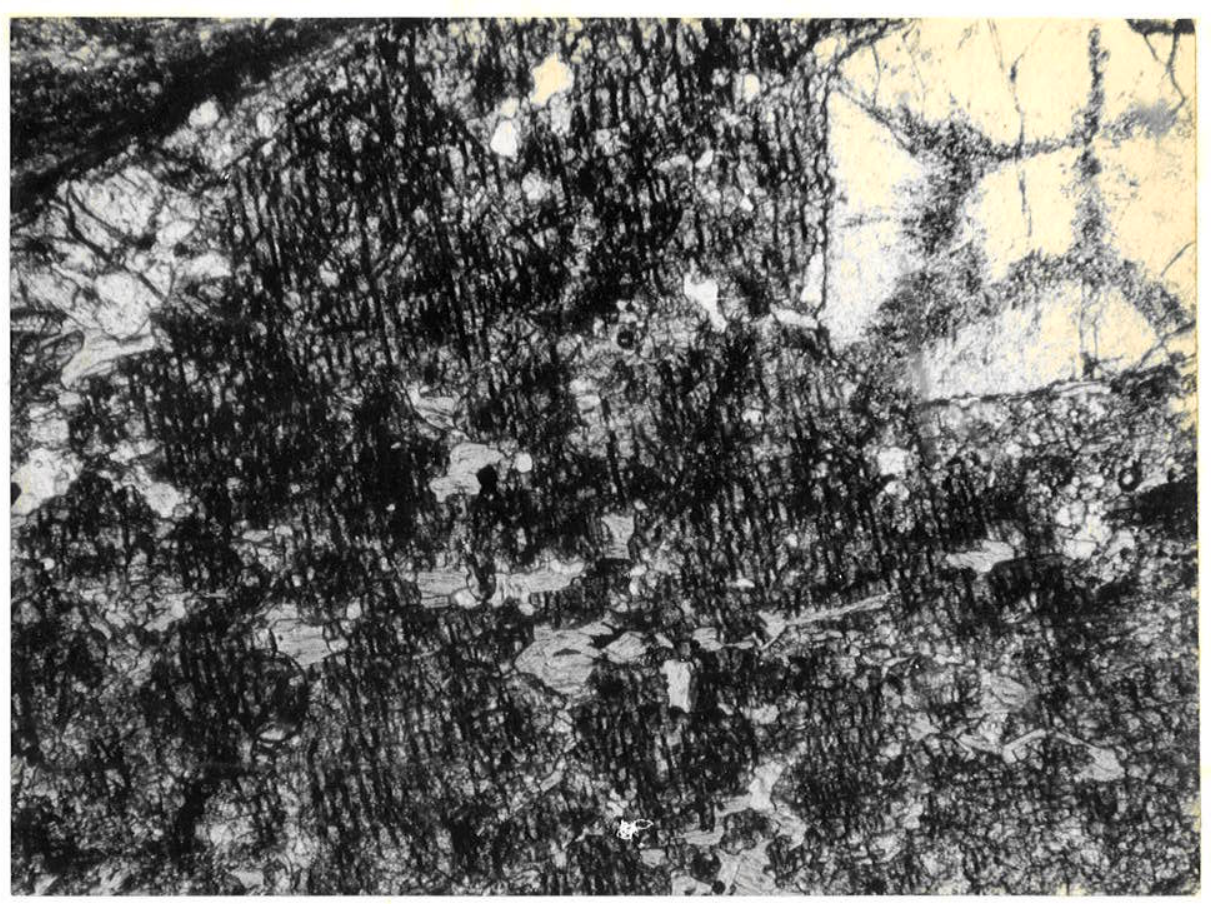

FOTO 55-Protominério carbonático de manganês. Macrocristal de piroxenóide (piroxmangita) com inclusões poiquilíticas de carbonato (Mn-kutnahorita) e manganofilita, associado a tefroita, espessartita e opacos (grafita e pirofanita). A granada é porfiroblástica e contém inclusões de grafita e de carbonatos finos. Amostra F12-76-117m. N. descruzados, X 35 .

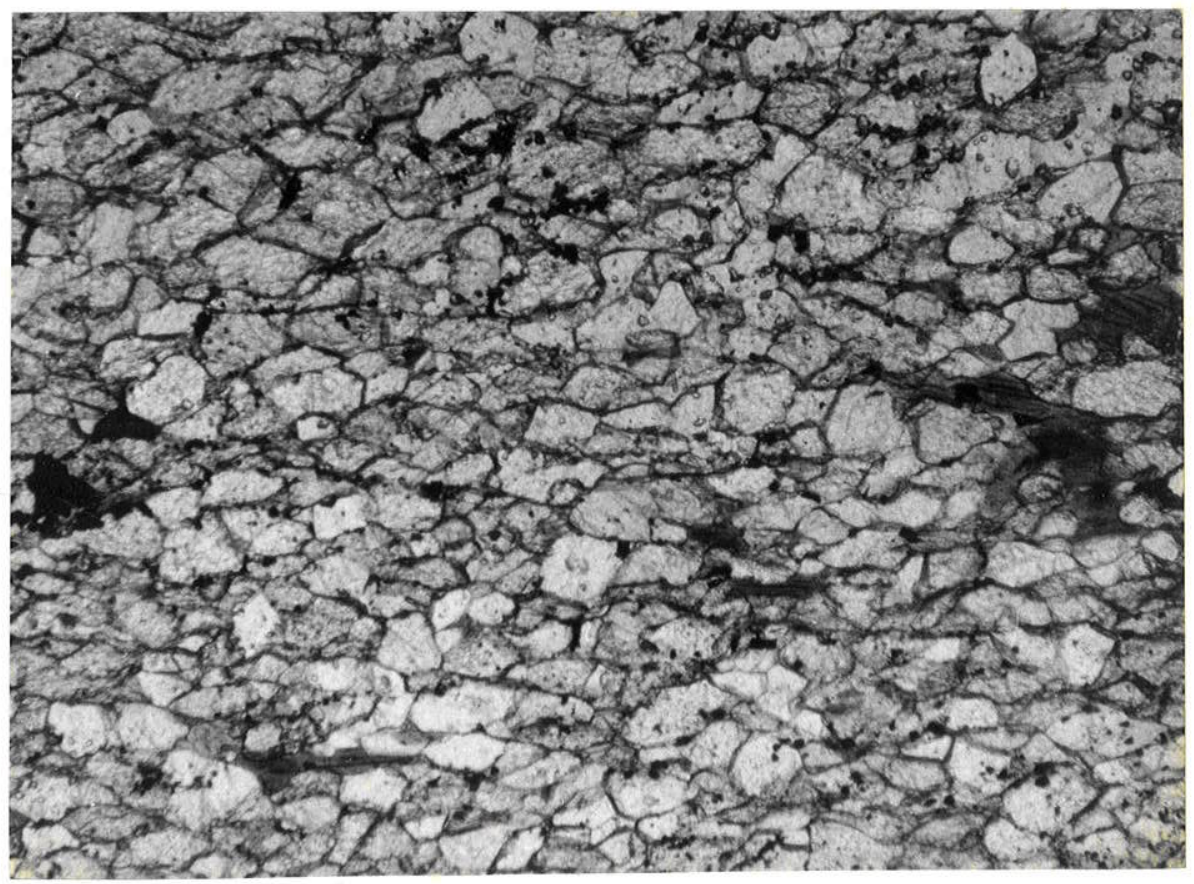

FOTO 56-Protominério carbonático de manganês. Mármore constituỉdo por carbo nato (Ca-rodocrosita) com textura em mosäico, manganofilita, pirofanita e opacos finos (grafita). Os carbonatos são alongados e junto às manganofilí tas, conferem uma orientação à rocha.Textura granoblástica orientada.Amostra F12-76-94.8m. N. descruzados, X 35. 


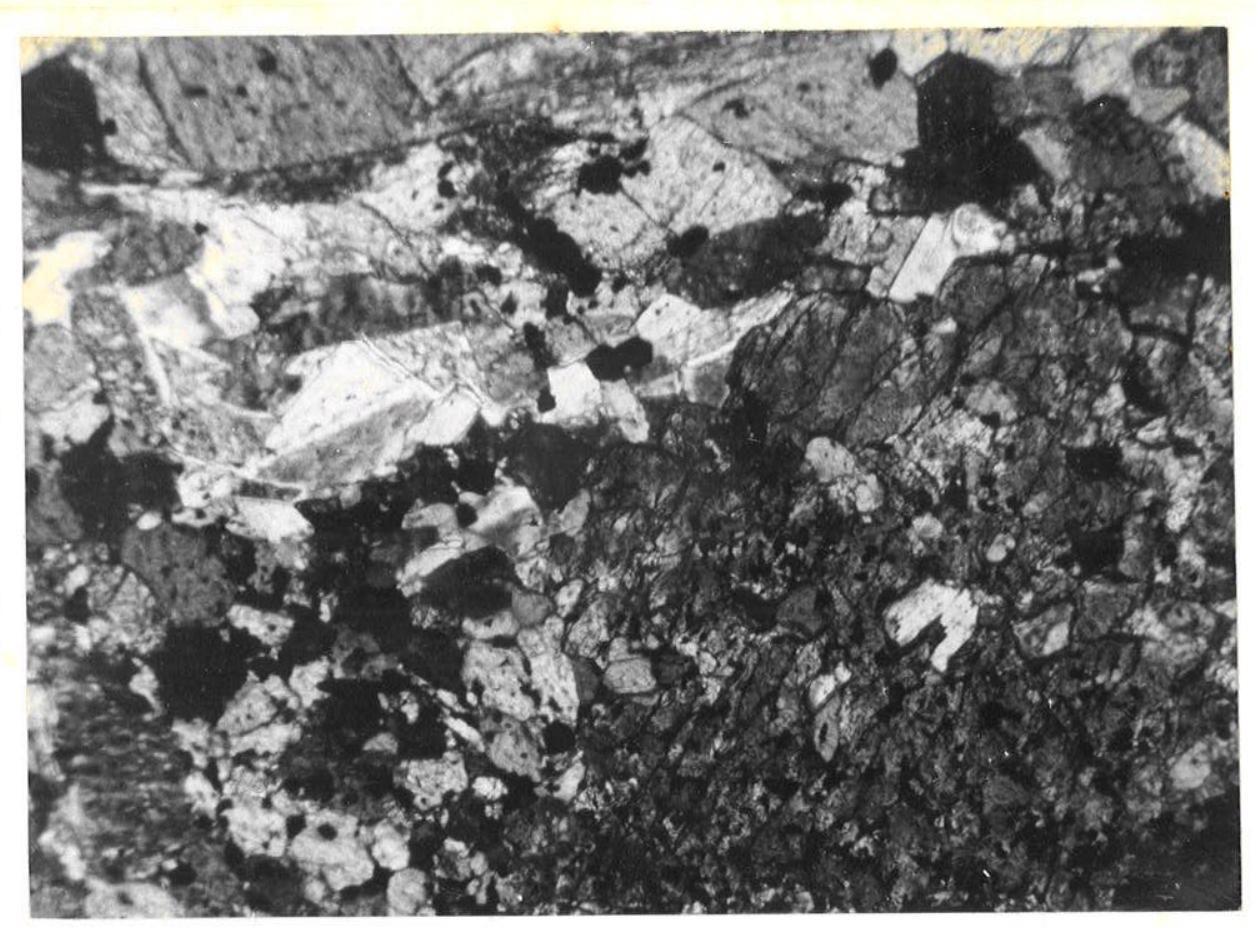

FOTO 57-Protominério carbonātico de manganês. Olivina (tefroita) porfiroblás tica incluindo carbonato, granada e grafita, associada à granada (espessartita), manganofilita, carbonato (Ca-rodocrosita), anfibólio manganesífero e opacos (grafita e pirofanita). Amostra F12-76-106,7m. N.cruzados, X 88.

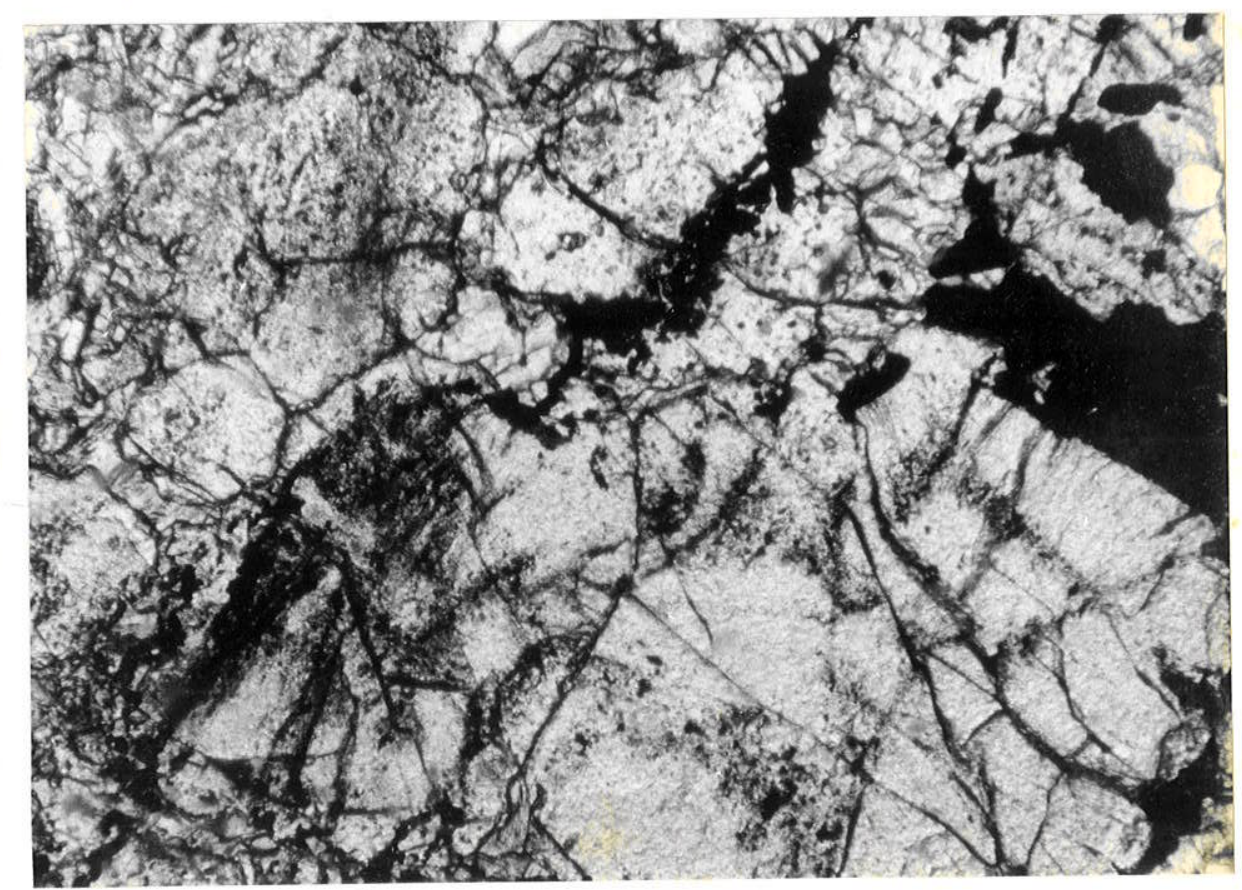

FOTO 58-Protominério carbonático de manganês. Associação de piroxmangitá,gra nada (espessartita), anfibólio manganesífero, carbonato (Mn-kutnahorita), manganofilita e faixas de pirofanita. A granada é porfiroblástica contendo inclusões poiquilíticas de grafita e pirofanita. Amostra F12-76-117m. N.des cruzados, X 35 . 


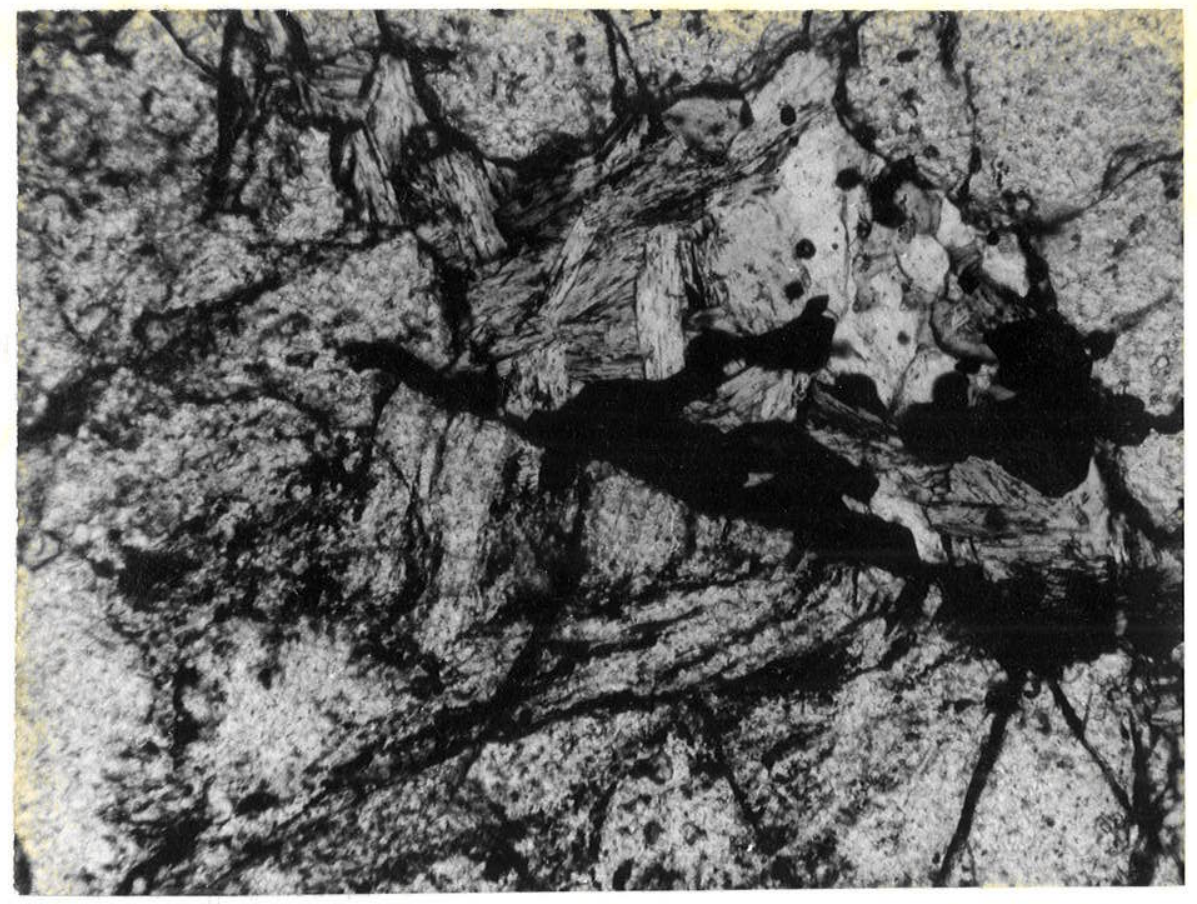

Fото 59- Protominério carbonätico de manganês. Detalhe onde aparece a associação: carbonato (Mn-kutnahorita), espessartita, pirofanita, manganofili ta e grafita. A espessartita possui inclusões de carbonato, grafita e de faixas de pirofanita. Amostra F12-76-117m. N.descruzados, X 88 .

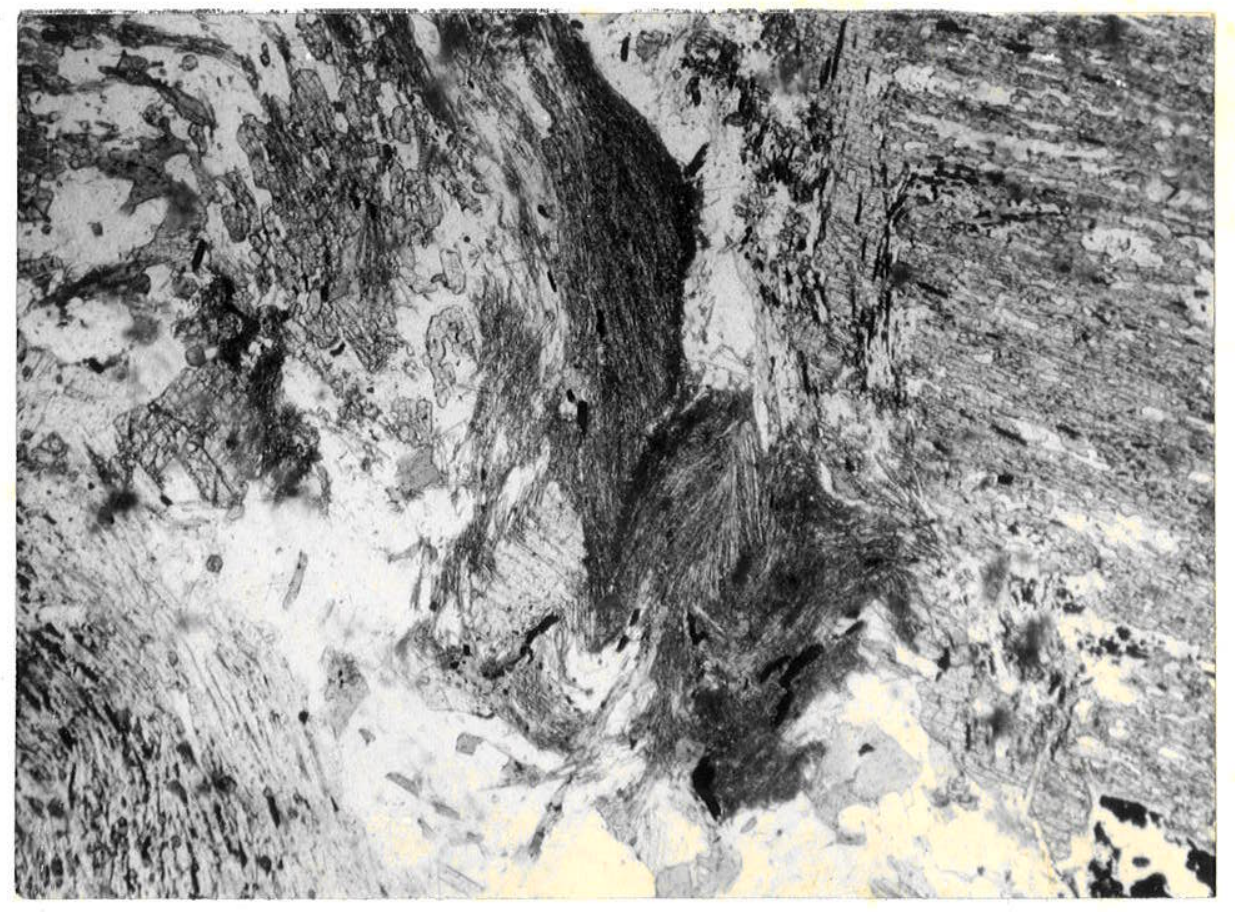

FOTO 60-Rocha metapelítica. Sillimanita-biotita xisto com andalusita. Macro cristais de andalusita de primeira geração (pré ou sintectônica) com in clusões planares e às vezes levemente encurvadas, de quartzo, muscovita, grafita e biotita. Crescimento de sillimanita posterior, a partir da anda lusita. A sillimanita ocorre como cristais fibrosos (fibrolita) orientados à $90^{\circ}$ da xistosidade primária. Andalusita de segunda geração, formada a par tir da sillimanita, contém inclusões orientadas na mesma direção da xistosí dade das sillimanitas. Amostra C2-32-148m. N. descruzados, X 35. 


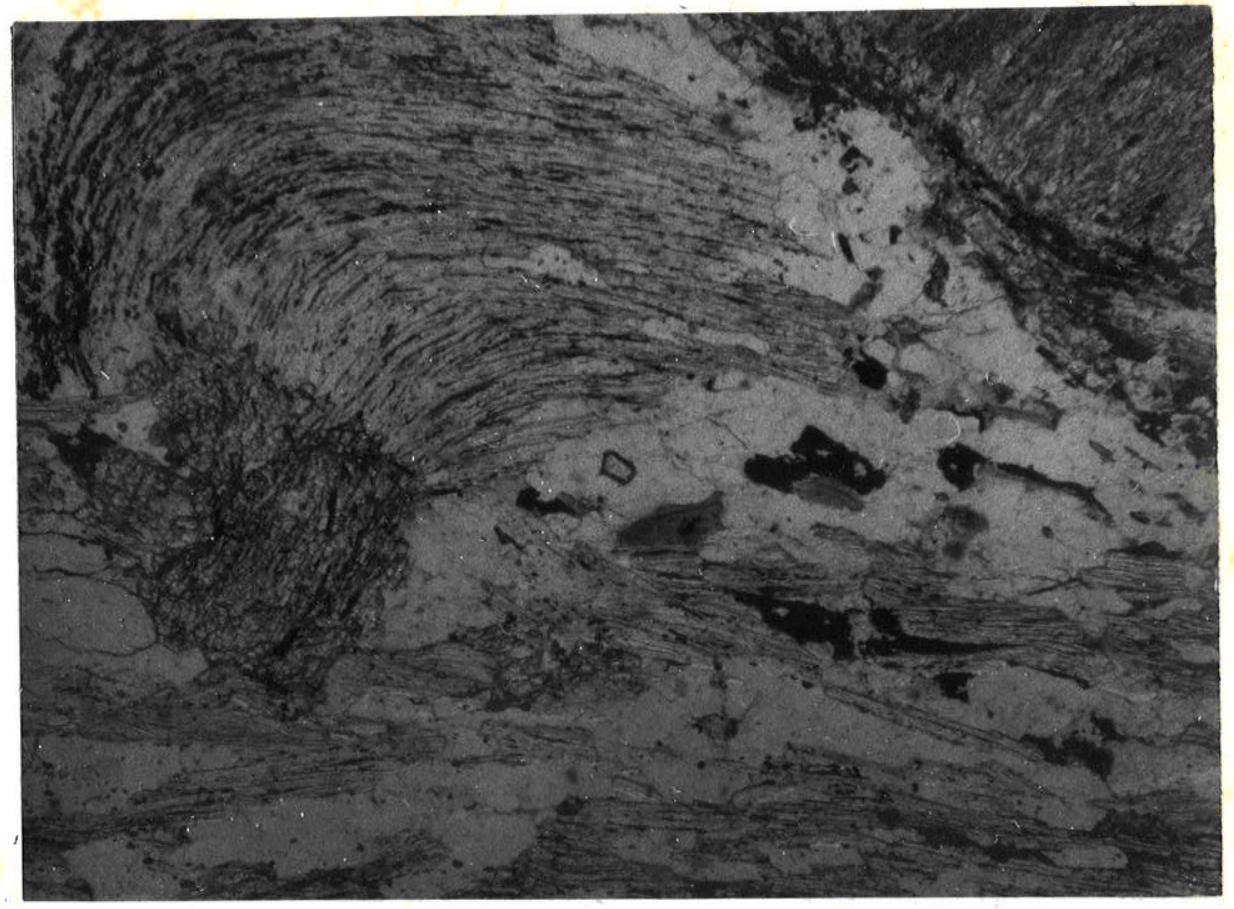

FOTO 61-Rocha metapelïtica. Sillimanita-biotita xisto com andalusita. Deta The onde aparecem cristais de andalusita de segunda geração formados a partir da sillimanita, ao lado da sillimanita (fibrolita), muscovita, bio tita e opacos. Textura lepidoblástica com crenulação salientada pela orien tação da sillimanita. Amostra C2-32-148m. N. descruzados, X 35 .

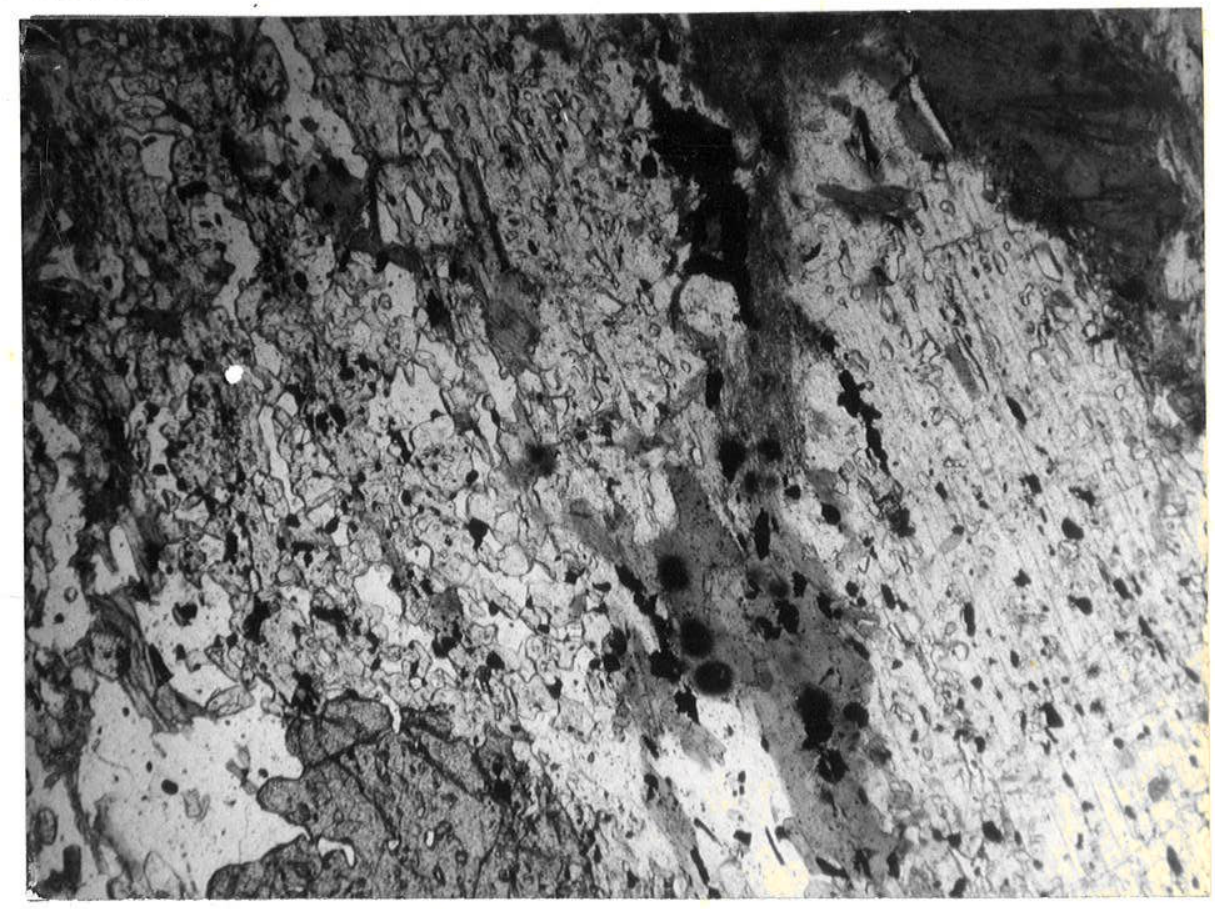

FOTO 62-Rocha metapelítica.Granada-biotita xisto com andalusita. Porfiroblas tos de andalusita com inclusoes poiquilíticas de quartzo, biotita e opacos. A andalusita está associada à granada, quartzo, biotita, muscovita e grafita. A grana ḑa tambèm possui inclusões poiquilíticas de quartzo e opacos.Tex tura lepidob́lástica com macrocristais de andalusita e granada. Amostra A12$-48-140 \mathrm{~m}$. N. descruzados, X 35 . 


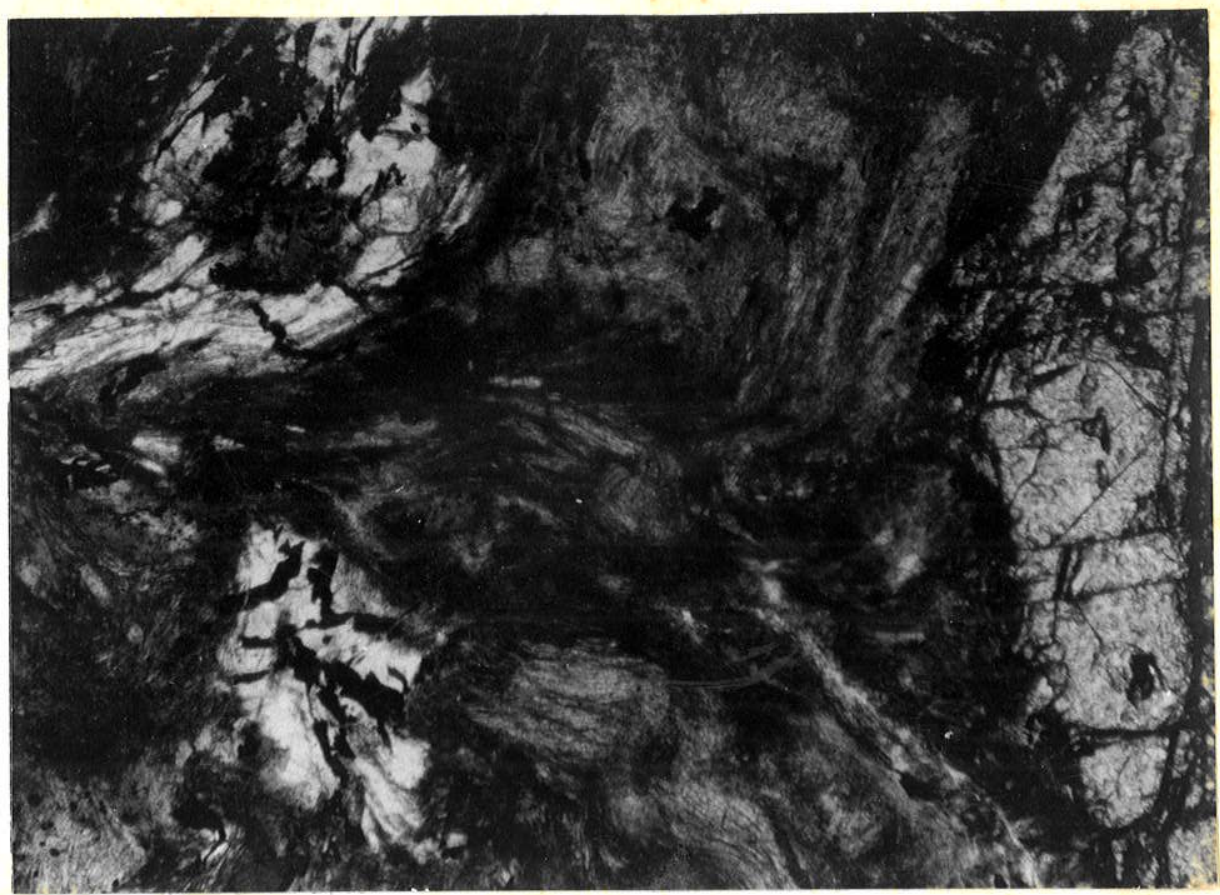

FOTO 63-Rocha metapelïtica.Sillimanita-granada-biotita xisto com cordierita. Associação de granada, sillimanita, cordierita, biotita, muscovita e opacos.Sombra de granada constituída por sillimanita (fibrolita) e cordierita. Transformação de sillimanita e biotita em cordierita e muscovita. Textura lepidoblästica com granadas porfiroblásticas. Amostra A12-48-139m. N. des cruzados, X 35 .

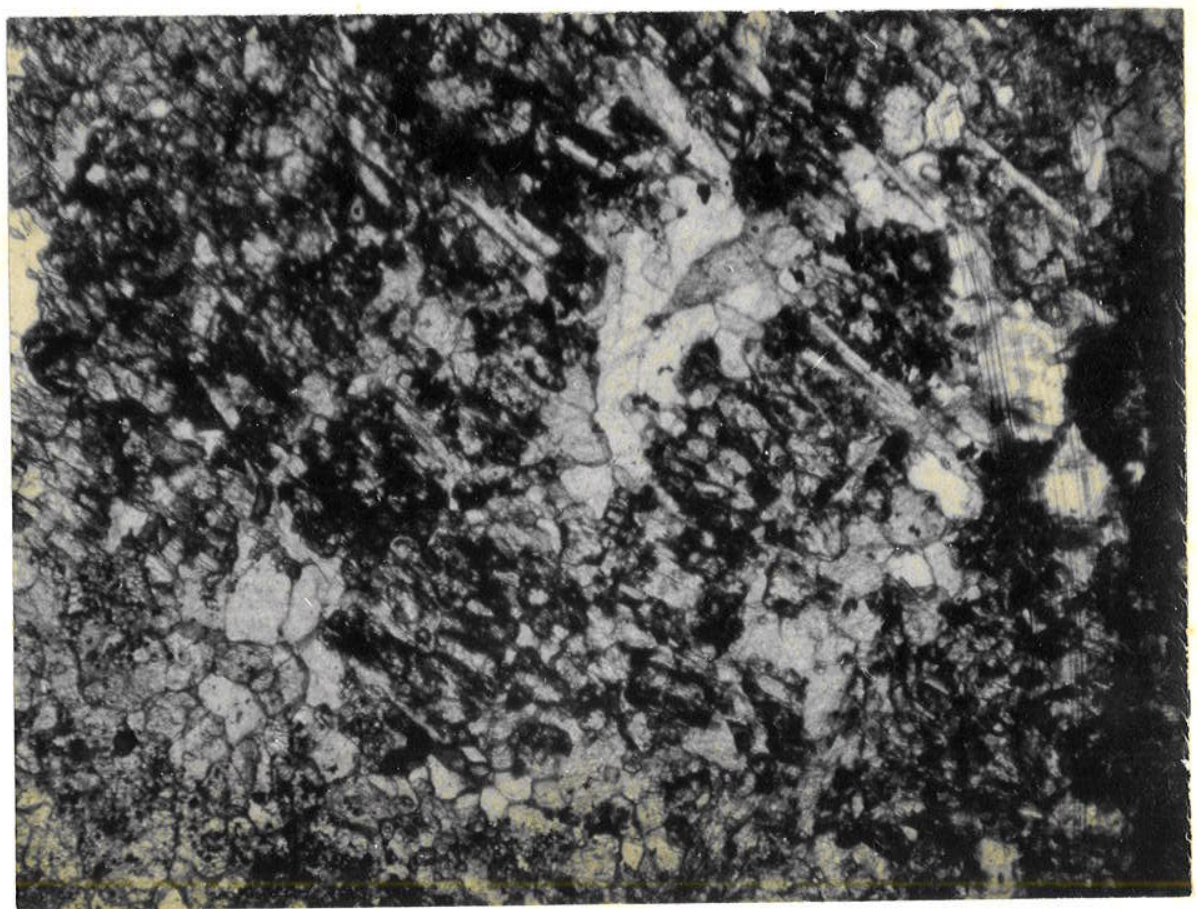

FOTO 64-Rocha calcossilicática. Associação de diopsídio e feldspato potássi co transformando-se em tremolita, calcita, muscovita e (quartzo). Textura nematoblástica dada por tremolita orientada e granoblástica devido aos de mais minerais. Amostra T6-59-118m. N. descruzados, X 35 . 


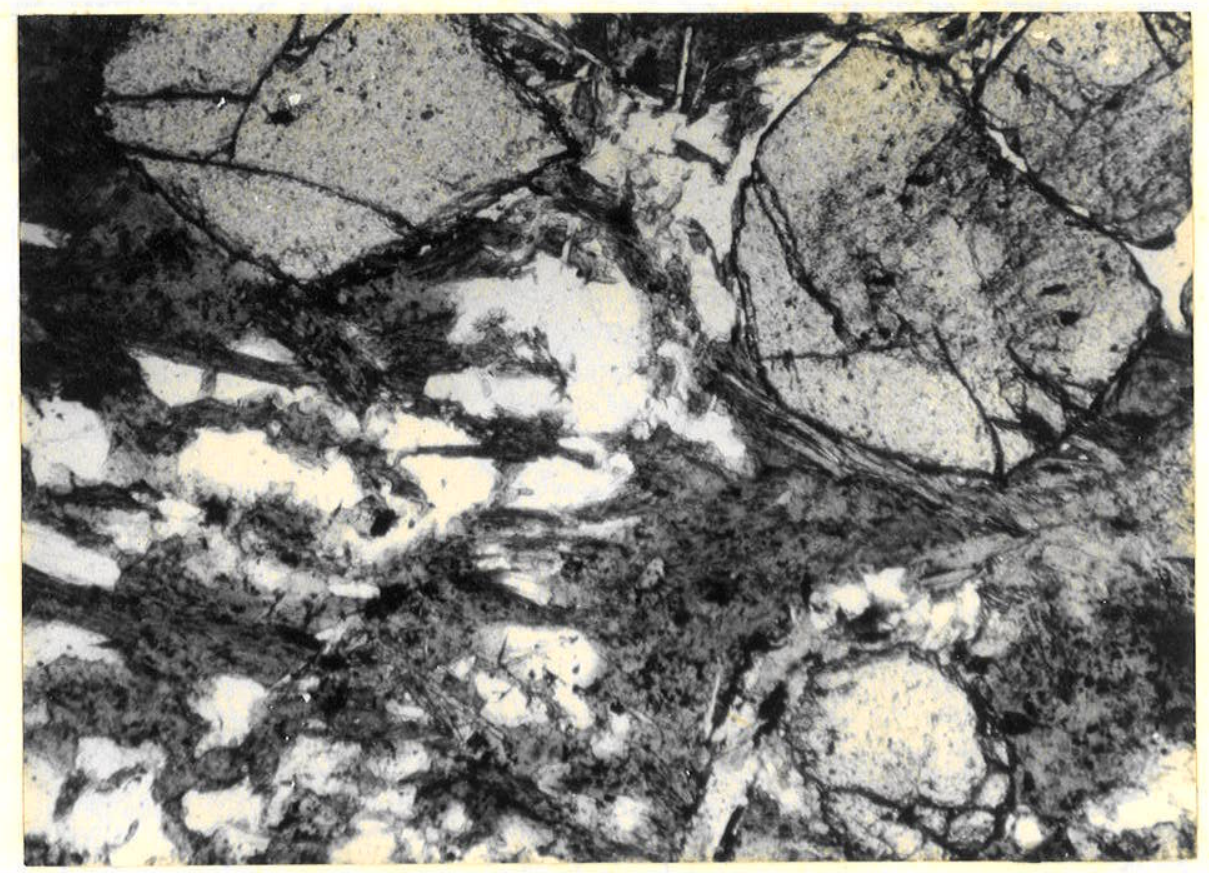

FOTO 65-Rocha rica em granada, contendo ainda quartzo, biotita e opacos, so frendo alteração com o aparecimento de muscovita, clorita (e epídoto ?). Partes claras-quartzo; cinza claras - clorita; ripas cinza claras - muscovita; cinza médias - biotita. Amostra T6-59-102m.N.descruzados. X 35 .

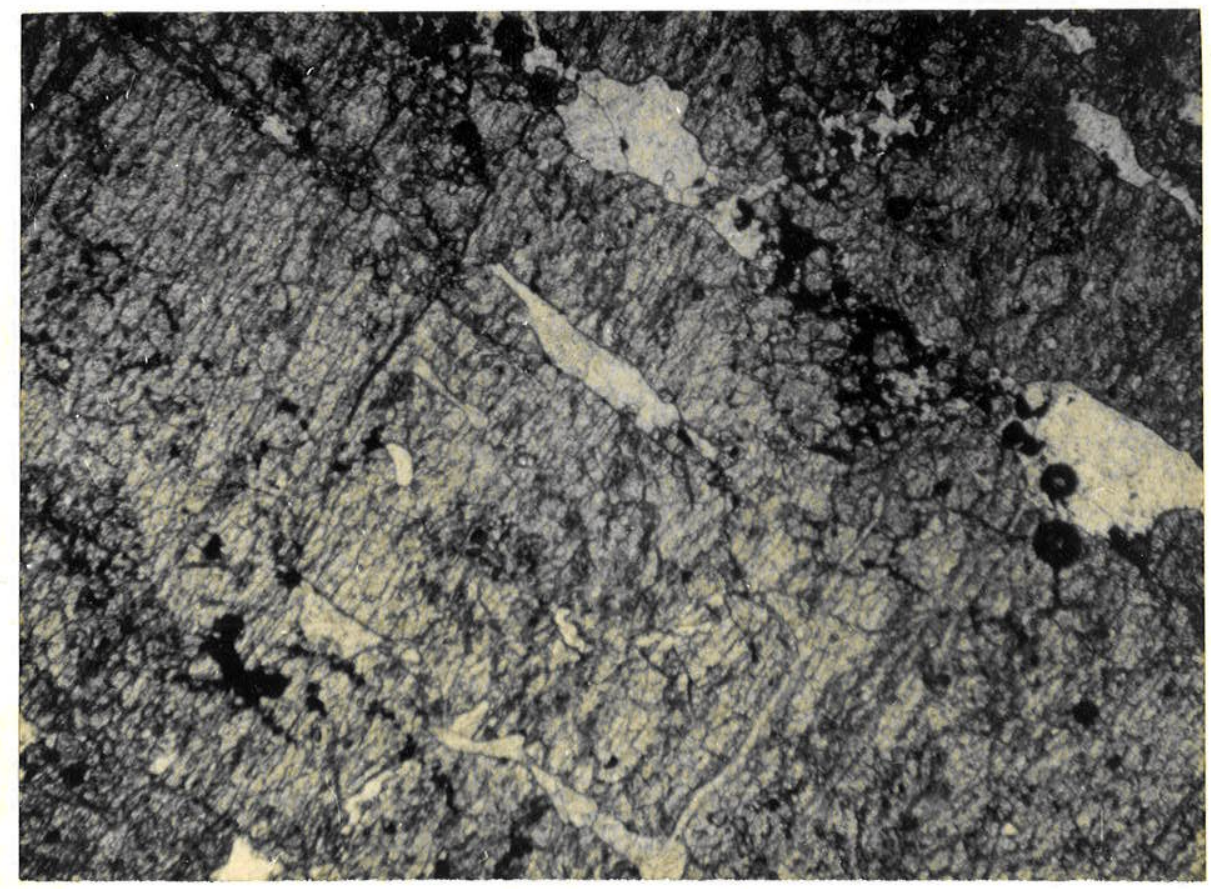

FOTO 66-Protominério carbonático de manganês. Porfiroblastos de tefroitas com inclusões poiquilíticas de granada (espessartita), carbonato e opacos (grafita). As tefroitas constituem macrocristais relativamente orien tados conferindo à rocha uma textura granoblästica orientada. Amostra $\mathrm{C} \overline{2}-$ $-43-48 \mathrm{~m}$. N. descruzados, X 35 . 


\section{CAPITULO $V$}

\section{DISCUSSAOO DOS RESULTADOS}

V - I - CONDIÇסES FISICO-QUIMICAS DO METAMORFISMO DE BURITIRAMA

o estudo mineralögico do protominério de Buritirama permitiu a caracterização de vărias associações mineralögicas as quais estão relacionadas abaixo:

(1) - carbonato + piroxmangita + tefroita

(2) - tefroita + carbonato + espessartita + pirofanita

(3) - tefroita + carbonato + piroxmangita + espessartita

(4) - carbonato + tefroita + espessartita + alabandita + + (esfaierita)

(5) - carbonato + braunita + manganofilita + Mn-anfibólio

(6) - Mn-clinopiroxênio + carbonato + manganofilita + + espessartita

(7) - Mn-clinopiroxênio + rodonita + carbonato

(8) - rodonita + carbonato + espessartita

(9) - Mn=clinopiroxênio + rodonita + carbonato + braunita

(10) - Mn-clinopiroxēnio + Mn=clinoanfibólio + manganofilita + + espessartita + carbonato

(11) - piroxmangita + manganofilita + carbonato

(12) - piroxmangita + Mn-ciinoanfibōlio + carbonato + + espessartita

(13) - piroxmangita + carbonato + espessartita + manganofilita

(14) - carbonato + braunita + hausmanita

(15) - carbonato + hausmanita

Analisando-se essas associações pela regra das fases, pode-se, numa primeira aproximação, considerar um sistema de 
cinco componentes fixos: Mn-Ca-Mg-Al-Si (desprezando-se Fe e K) e de três componentes möveis: $\mathrm{CO}_{2}, \mathrm{H}_{2} \mathrm{O}$ e $\mathrm{S}_{2}$ (fase fluida). Dessa maneira paragêneses de quatro fases sólidas indicam um sistema trivariante. E o que acontece em geral com parageneses sem flo gopita. Adicionando-se esta ūitima equivale a considerar um sis tema a seis componentes com a inclusão do potāssio e o sistema permanece trivariante para associações com cinco fases sölidas e uma fase fluida, normalmente observadas.

A paragênese $(1)$ = carbonato manganesifero + piroxman gita + tefroita (Fotos 28 e 30 ) é prevista no sistema teörico Mn-Si-C-O-H como resultado da reação.

$\mathrm{MnCO}_{3}+\mathrm{MnSiO}_{3}=\mathrm{Mn}_{2} \mathrm{SiO}_{4}+\mathrm{CO}_{2}$ (rodocrosita + piroxmangi ta $=$ tefroita) - (PETERS et al., 1974).

A Figura 12 mostra essa reação sob no 10 num diagrama isobärico $\mathrm{Tx}_{\mathrm{logf}} \mathrm{O}_{2}$ supondo $\mathrm{X}_{\mathrm{CO}_{2}}=1$. 0 efeito da pressäio tótal tende a aumentar a temperatura de equilibrio dessa reaçäo, ao mesmo tempo que fração molar de $\mathrm{CO}_{2}$ inferior a 1 tende a diminuí-. -1 a. A paragēnese $(9)=$ clinopiroxēnio manganesífero + rodonita + + braunita + carbonato manganesiffero (Fotos 10,32) apresenta gran de importância salientando a influência do cao no politipismo do piroxenóide manganesífero.

A associação de clinopiroxênio manganesifero (johanse nita) com os piroxenóides de manganēs (piroxmangita, rodonita e bustamita) foi objeto de trabalho de ABRECHT \& PETERS (1975). Em bora o diagrama experimental apresentado seja um diagrama de sin tese efetuado à 2.000 bars, existe a possibilidade da associação johansenita-rodonita ser estävel acima de $500^{\circ}$, afirmação que $\bar{e}$ tanto mais verdadeira quanto maior for a pressão total (Figura 25).

A paragênese $(14)$ = carbonato + braunita + hausmanita no sistema puro $\mathrm{Mn}-\mathrm{Si}-\mathrm{C}-\mathrm{O}-\mathrm{H}$ corresponde a um ponto isobärico in variante que fixaria $\log \mathrm{f}_{\mathrm{O}_{2}}$ eln -8 aproximadamente e temperatura .em torno de $450^{\circ}$ a 2.000 bars, considerando-se $x_{\mathrm{CO}_{2}}=1$. (Figura 


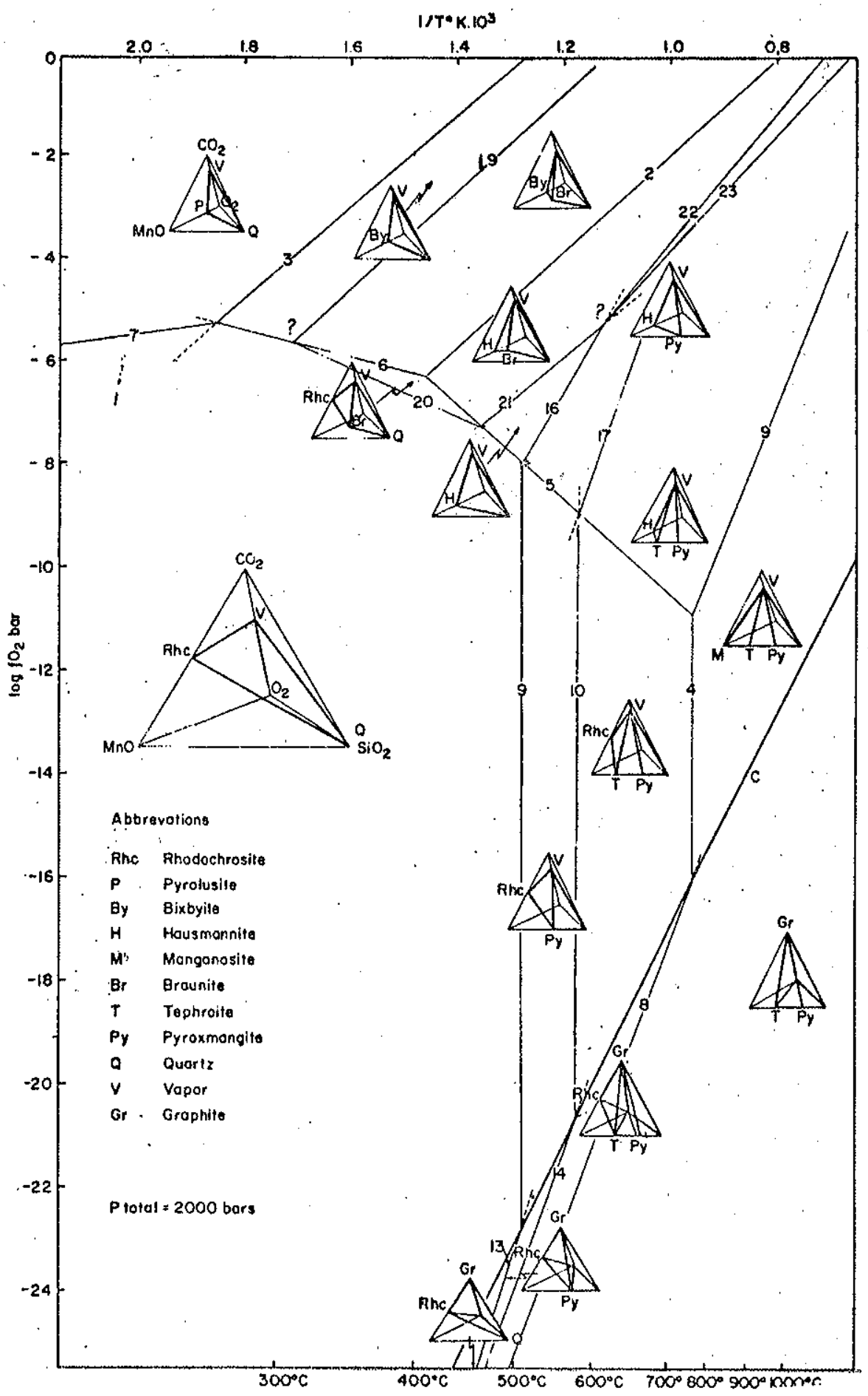

Figura 12 - Diagrama isobärico $\mathrm{T}-1 \mathrm{log} \mathrm{fO}_{2}$ para o sistema $\mathrm{Mn}-\mathrm{C}-\mathrm{Si}-\mathrm{O}-\mathrm{H}$ à pressão total 2.000 bars e $\mathrm{XCO}_{2}=1$ - Segundo $\mathrm{PE}-$ TERS et al., 1974 . 
12, reação 20). No entanto, o carbonato associado à braunita no braunita mārmore $\vec{e}$, frequentemente, mangano calcita, devendo-se na interpretação desses dados levar em conta a atividade do $\mathrm{MnCO}_{3}$ neste carbonato. A mangano calcita é uma solução sōlida de $\mathrm{CaCO}_{3}$ e $\mathrm{MnCO}_{3}$ significando que a atividade do $\mathrm{MnCO}_{3}$ nesse car bonato è menor que 1 , implicando num aumento da fugacidade de $\mathrm{O}_{2}$ quando comparado $\mathrm{Com} \mathrm{MnCO}_{3}$ puro.

A braunita pode ser formada atravēs de vārias reações: reação entre rodocrosita e quartzo, oxidação da piroxmangita ou ainda pela reação entre óxidos de manganēs e quartzo ou piroxe nóides. (reações $18,20,21,22$ e 23 de PETERS, VALARELLI \& CAN DIA, 1974).

A reação entre rodocrosita e quartzo no metamorfismo progressivo tende a formar normalmente piroxenōides associados à rodocrosita ou raramente a quartzo quando houver excesso de silli. ca. Por outro lado, em nenhum caso foi observada oxidação de pi. roxenóides. Quando estes ūltimos são afetados por veios ou por retrometamorfismo, nota-se seja serpentinização, seja transforma ção em anfibôlios.

Em algumas lâminas (Foto 9) nota-se uma estrutura ban deada imposta a sedimentos interestratificados compostos essen cialmente de carbonatos e óxidos. Isso indica que provavelmente a braunita formou-se a partir da reação entre quartzo e óxidos de manganês (hausmanita ou bixbyita). Estes ültimos poderiam ser produto de metamorfismo de hidrōxidos sedimentares ou então da decomposição de mangano calcita que na impossibilidade de formar piroxenóides e muito menos wollastonita, ter-se-ia decomposto em oxido de manganês + calcita, segundo GOLDSMITH \& GRAF (1957), jus tificando assim a paragênese = carbonato + hausmanita.

Veios e massas silicāticas encontrados no braunita mär more apresentam paragēneses complexas. Algumas vezes a partir de um nūcleo de quartzo + apatita + barita + feldspato potássico hā passagem gradual para zonas de rodonita granoblástica de gra nulação grosseira (atē $7 \mathrm{~mm}$ ). No contato entre as zonas de rodo 
nita e as massas de braunita + Mn-flogopita + Mn-calcita, existe uma faixa milimétrica de clinopiroxênio + clinoanfibölio e Mn-flo gopita (Fotos 10, 26).

Provavelmente, trata-se de fenōmeno de remobilização de sîlica que ocorreu a pequenas distâncias em condições metamōrfi. cas talvez não longe do pico do metamorfismo, visto os resulta dos das inclusões fluidas dos cristais de quartzo.

A rodonita dessas faixas representariam reação entre a sîica e carbonatos manganesīferos enquanto que a associação cli nopiroxênios, clinoanfibölios, Mn-flogopita deve representar rea ção entre carbonatos pouco manganesiferos e a mesma sijica acom panhada pela alteração de silicatos e aluminossilicatos.

Infelizmente faltam dados teöricos e experimentais pa ra analisar a influência da espessartita, da manganofilita e dos clinoanfibölios manganesifferos vistos em diversas associações, no deslocamento ou na particularização dos equilïbrios. Muito fa] ta ainda para a anāise completa da presença de alabandita, espj. nēilo, pirofanita e outros acessörios.

Se nos protominērios hä predominäncia de minerais cal comanganesiferos, nas rochas encaixantes predominam minerais calco-magnesianos.

Nas rochas encaixantes mais carbonäticas è relativamen te comum a associação isobärica divariante calcita + diopsídio + + tremolita (Fotos 2, 4, 11, 12) cujos campos de estabilidade são muito variāveis em função de $\mathrm{P}, \mathrm{T}$ e $\mathrm{X}_{\mathrm{CO}_{2}}$ (SKIPPEN, 1974). Em aI gumas lâminas a associação isobārica univariante calcita + diop sidio + tremolita + quartzo foi encontrada (Foto 17), indicando pressão de fluido superior a $1,5 \mathrm{~Kb}$ à temperaturas superiores a $550^{\circ} \mathrm{C}$ indicada pela missibilidade dos carbonatos vista anterior mente. Segundo WINKLER (1976) esse equilíbrio apresenta um pata mar em diagrama isobärico $\left(\mathrm{T} \times \mathrm{X}_{\mathrm{CO}_{2}}\right)$ com seu mäximo valor de $\mathrm{X}_{\mathrm{CO}_{2}}$ $=0,8$ e variando de $540^{\circ} \mathrm{C}$ à pressão de $1 \mathrm{~Kb}$ até $655^{\circ} \mathrm{C}$ à $5 \mathrm{~Kb}$ ( $\mathrm{F} \underline{\mathrm{i}}$ guras 15a, 15b e Figura 9-6. de WINKLER, 1976, p. 122). 
A associação calcita + dolomita + quartzo + diopsĩdio + tremolita tambēm foi encontrada representando um ponto isobä rico invariante e elevada fração molar do $\mathrm{CO}_{2}$.

Essa associação pode ser vista no diagrama isobärico $\mathrm{T} \times \mathrm{X}_{\mathrm{CO}_{2}}$, da Figura 13 (SKIPPEN, 1974) no ponto (2) indicando um alto valor da fração molar do $\mathrm{CO}_{2}$ e uma temperatura entre 500 e $600^{\circ} \mathrm{C}$ dependendo da pressão total (Figura 15a, ponto II).

Alguns grãos de quartzo de massas silicosas concordan tes preservadas nos protominērios de manganês de Buritirama fo ram selecionados para o estudo das inclusões fluidas. Tal estu do (VALARELLI \& VON RAUMER, 1975) revelou a presença de inclü sões fluidas de vārias gerações com diferentes frações de $\mathrm{CO}_{2}$.

As inclusões primärias eram mono e bifásicas e conti nham quase que exclusivamente $\mathrm{CO}_{2}$, sendo que nas inclusões tar dias a concentração de $\mathrm{CO}_{2}$ diminuia aparecendo inclusões trifá sicas com $\mathrm{CO}_{2}$ líquido, $\mathrm{CO}_{2}$ găs e $\mathrm{H}_{2} \mathrm{O}$ lîquido de alta salinidade.

Nas inclusões bifásicas, $\mathrm{CO}_{2}(1)$ e $\mathrm{CO}_{2(\mathrm{~g})}$, as homogenei zações tenderam a formar uma sö fase liquida.

A Figura 14 apresenta os resultados do estudo de 394 inclusões, constando dela as temperaturas de homogeneização ob tidas, e as correspondentes densidades criticas do $\mathrm{CO}_{2}$ de cada uma (LANDOLF-BOERNSTEIN tables, 1960).

o valor médio da temperatura de homogeneização estā entre $8-9^{\circ} \mathrm{C}$ correspondendo a uma densidade critica do $\mathrm{CO}_{2}$ de $0,87 \mathrm{~g} / \mathrm{cm}^{3}$, que conforme os dados de KENNEDY (1954) representa um gradiente de $10^{\circ} \mathrm{C} / 53$ bars $\left(54^{\circ} \mathrm{C} / \mathrm{Km}\right)$.

Em vista dos dados paragenéticos discutidos anterior mente dos protominérios e das encaixantes de Buritirama, pode- se supor uma temperatura de $550 \pm 50^{\circ} \mathrm{C}$ para o pico do metamor fismo. Assim, os dados de inclusões fluidas fornecem pressões totais da ordem de $3.000 \pm 300$ atmosferas. 

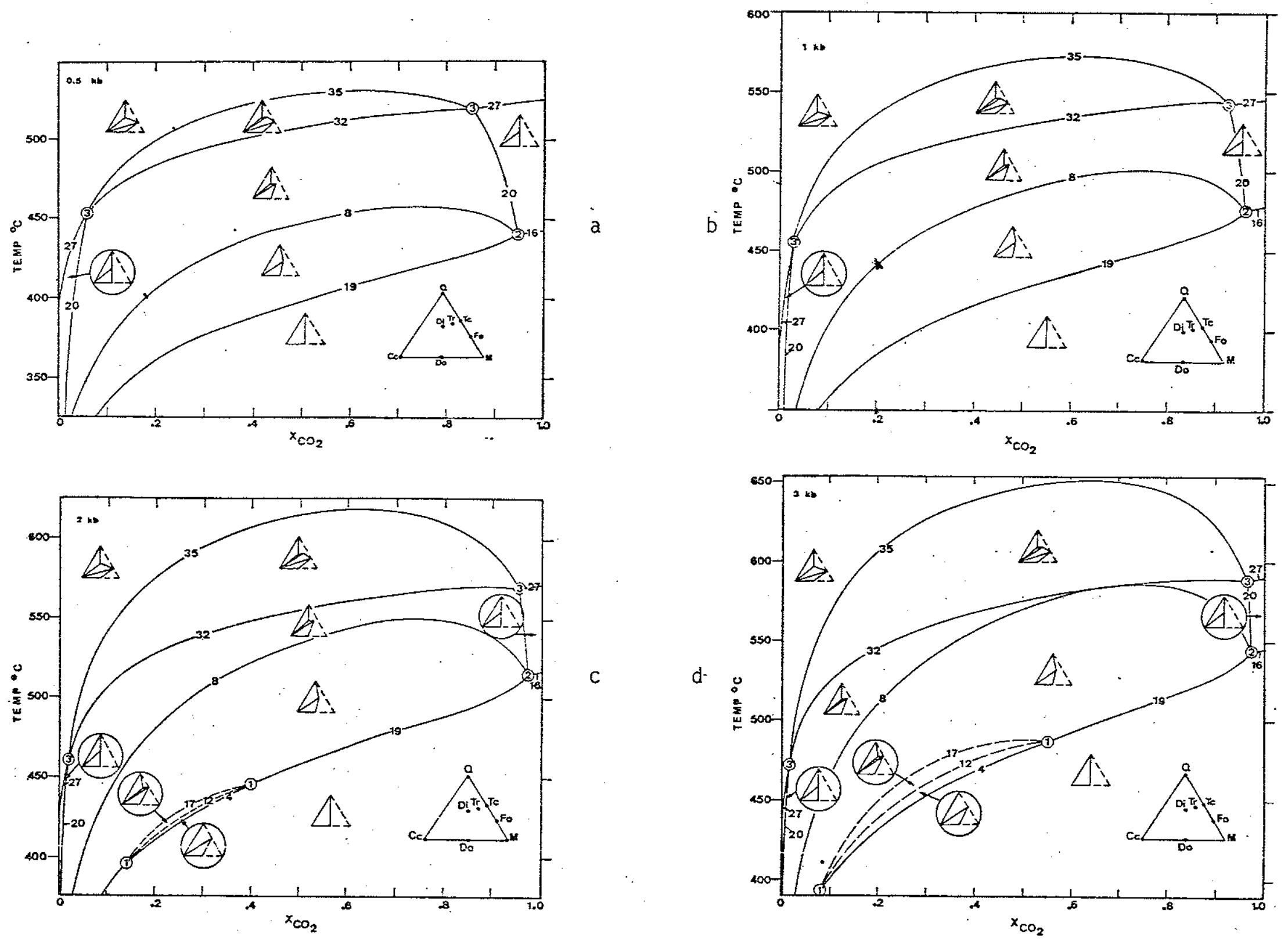

Figura 13 - Diagrama isobärico $\mathrm{T}-\mathrm{XCO}_{2}$ para o sistema $\mathrm{CaO}-\mathrm{MgO}-\mathrm{SiO}_{2}-\mathrm{H}_{2} \mathrm{O}-\mathrm{CO}_{2}$ à vārias pressões totais - Segundo SKIPPEN, 1974. 


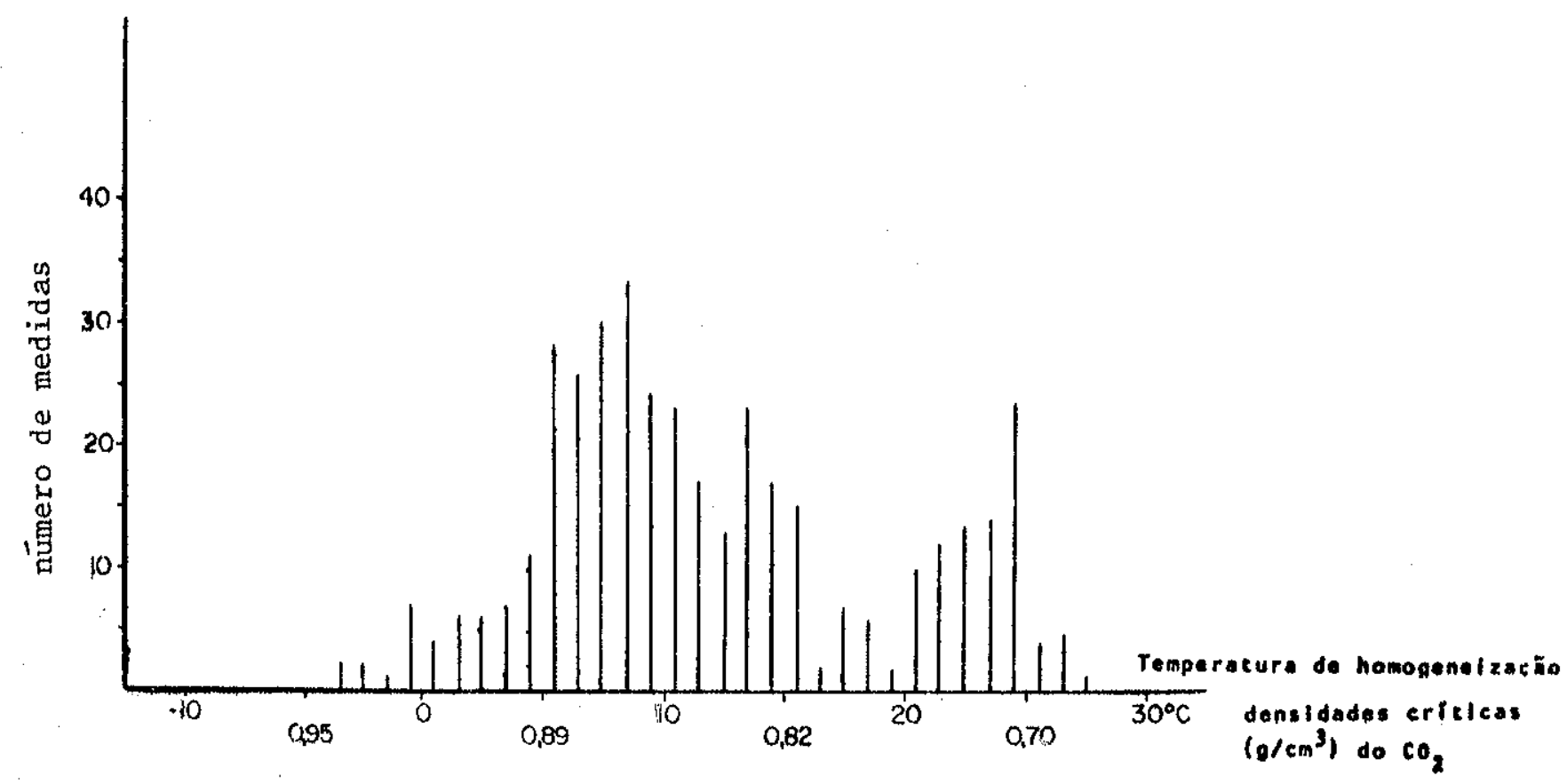

Figura 14 - Densidades criticas de $\mathrm{CO}_{2}\left(\mathrm{~g} / \mathrm{cm}^{3}\right)$ e temperatura de homo geneização de 394 inclusões fluidas em cristais de quartzo preservados no Braunita mármores de Buritirama (furo de sonda $35-10$ ) - Segundo VON RAUMER \& VALARELLI, 1977 。 
V - 2 - CONDIÇÕES FISICO-QUIMICAS DO METAMORFISMO DE SEFRA DO NAVIO

As seguintes paragēneses são comuns nos protominērios de Serra do Navio:

(1) carbonato + rodonita + tefroita \pm espessartita + + grafita

(2) carbonato + tefroita + grafita

(3) carbonato + tefroita + espessartita + grafita

(4) rodonita + carbonato + grafita

(5) espessartita + rodonita + carbonato + grafita

(6) carbonato + tefroita + Mn-flogopita + grafita

(7) carbonato + tefroita + Mn-flogopita + espessarti ta+grafita

(8) tefroita + Mn-anfibölio + carbonato + Mn-flogopita + grafita

(9) carbonato + piroxmangita + Mn-flogopita + grafita

(10) espessartita + piroxmangita + carbonato + Mn-flogopita + grafita

(11) piroxmangita + carbonato + tefroita + grafita

(12) piroxmangita + carbonato + Mn-anfibölio + + espessartita + grafita

Considerando $\mathrm{H}_{2} \mathrm{O}, \mathrm{CO}_{2}$ e $\mathrm{S}$ como componentes möveis e seis componentes fixos: $\mathrm{Si}, \mathrm{Al}, \mathrm{Mn}, \mathrm{Ca}, \mathrm{K},(\mathrm{Fe}+\mathrm{Mg})$, as paragê neses observadas de um mäximo de cinco fases sōlidas e uma fase fluida indicam um sistema trivariante.

A paragênese $(1)=$ carbonato manganesifero + rodonita + tefroita \pm espessartita + grafita (Foto 42) e a paragênese (11) piroxmangita + kutnahorita + tefroita + grafita (Foto 55), são importantes pois mostram a coexistência da rodonita com car bonato mais rico em călcio e da piroxmangita com carbonato mais rico em manganês, isto è, a importāncia do cālcio no tipo de pi roxenóide formado. 
A menos da grafita, a associação de piroxenóide-olivi na-carbonato é isobärica univariante, coincidente com a reação 10 de PETERS et al., 1975 , à temperatura constante $\cong 600^{\circ} \mathrm{C}, \quad \mathrm{f}$ xando-se $\mathrm{X}_{\mathrm{CO}_{2}}=1, P=2.000$ bars, e independente da fugacidade de oxigênio.

A presença de grafita nessa associação passa a ter uma importāncia muito grande pois ela indica um equilibrio em que a grafita funciona como tampão. Esse equilíbrio ē visto em PETERS et al., 1975, reação 14, que naquelas condições experimentais consideradas $\left(P=2.000\right.$ bars e $\left.X_{\mathrm{CO}_{2}}=1\right)$ determinam uma tempera tura māxima de aproximadamente $600^{\circ} \mathrm{C}$ e fugacidade mäxima segundo $\log \mathrm{fo}_{2}<-21$.

Das outras paragẽneses observadas, algumas estão conti das nas analisadas e em outras aparecem minerais tais como a es pessartita, manganofilita e anfibōito manganesífero, cuja in fluência nas condições de equilíbrio não podem ser deduzidas de vido a falta de dados teóricos e experimentais.

Lentes de rochas calcossilicăticas, que ocorrem inter caladas nas encaixantes mais quartzosas dos protominērios, apre sentam como minerais caracteristicos, calcita, tremolita e diop sidio (e ocasionalmente, hornblenda) (Fotos 48,49 e 64). Esses minerais ocorrem em bandas milimétricas a centimétricas parale las ao bandeamento da rocha, em porcentagens variāveis. Em mär mores calciticos claros ocorrem quartzo, biotita, tremolita,diop sidio, titanita, sulfetos e grafita.

A associação calcita + tremolita + diopsídio encontra da nessas rochas (Fotos 48 e 49 ) possui um amplo campo de estabi lidade, o que pode ser visto no diagrama isobärico $\mathrm{T} \times \mathrm{X}_{\mathrm{CO}_{2}}$ da

Figura 13 existindo atê um mäximo de $650^{\circ} \mathrm{C}$ quando é considerada a pressão constante de $3 \mathrm{~kb}$. Esse valor de temperatura porém serä maior para pressões maiores. No diagrama isobärico da Figu ra 15 (WINKLER, 1976) construído à $P=5 \mathrm{~kb}$, observa-se essa as sociação existindo atē aproximadamente $730^{\circ}$. 
a
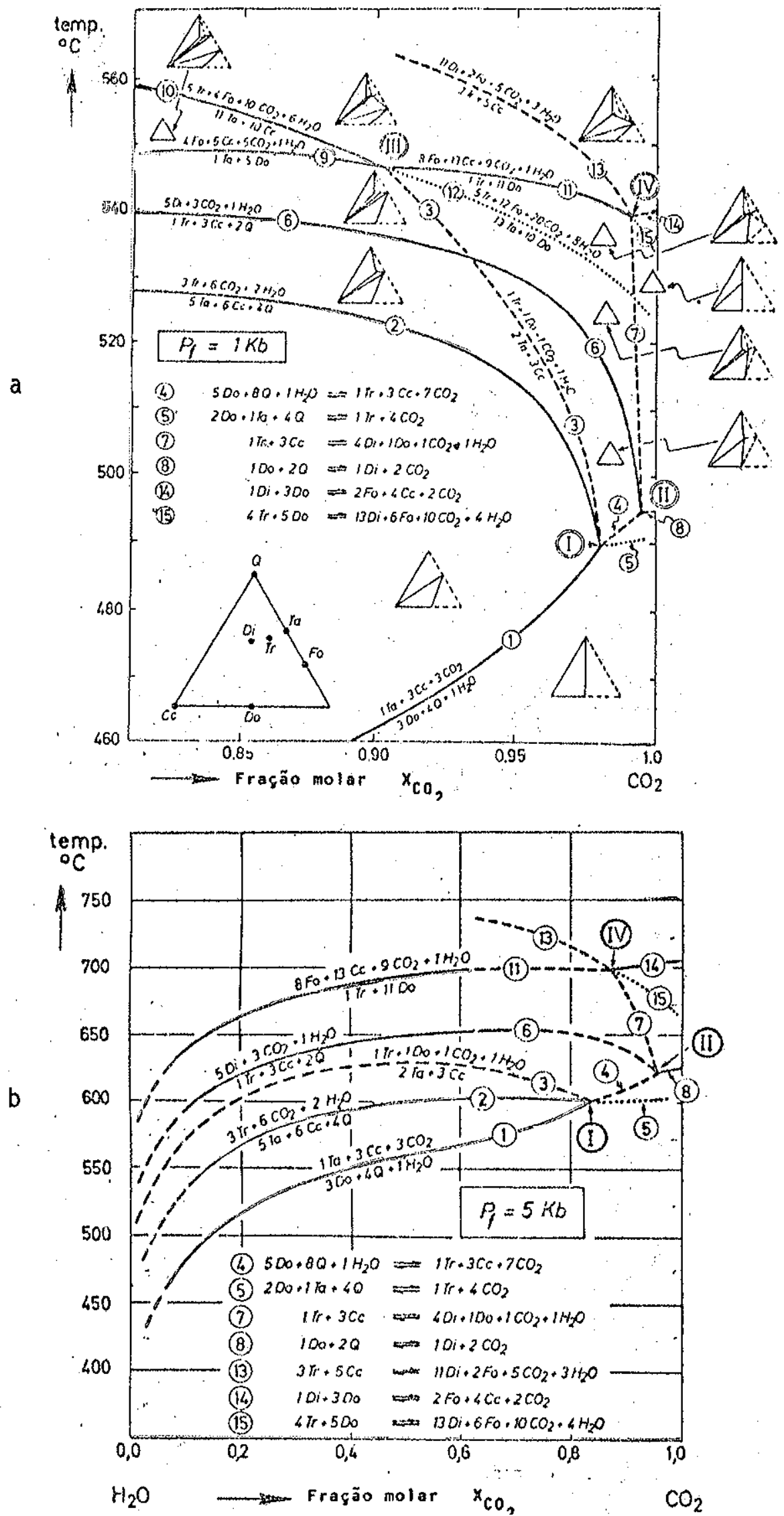

Figura 15 - Diagrama isobarico $\mathrm{T}-\mathrm{X}_{\mathrm{CO}_{2}}$ para o sistema CaO-MgO$\mathrm{SiO}_{2}-\mathrm{H}_{2} \mathrm{O}-\mathrm{CO}_{2}:$ à $\mathrm{PE}=1 \mathrm{~Kb} \mathrm{e} \cdot \mathrm{Pf}=5 \mathrm{~Kb}-$ 
A presença de quartzo (Fotos 48 e 49) nessa associa ção como jā foi mencionado na paragēnese de Buritirama, corres ponde a um equilíbrio isobārico univariante com os pares $P, T \bar{a}$ $\mathrm{X}_{\mathrm{CO}_{2}}=0,7-0,8: 500^{\circ} \mathrm{C}-1 \mathrm{~Kb} ; 550^{\circ} \mathrm{C}-2 \mathrm{~kb} ; 580^{\circ} \mathrm{C}-3 \mathrm{~kb}$; $620^{\circ} \mathrm{C}-4 \mathrm{~Kb}$ e $650^{\circ} \mathrm{C}-5 \mathrm{~Kb}$ (SKIPPEN, 1974).

As encaixantes metapelïticas correspondentes aos xis tos, grafitosos ou não, possuem associações mineralōgicas muito variāveis. As principais paragêneses encontradas são as seguin tes:

(13) biotita - quartzo - grafita - andalusita - sillimanita

(14) andalusita - biotita - muscovita - quartzo

(15) biotita - quartzo - plagiocläsio - cordierita - sulfetos - grafita

(16) cordierita - quartzo - biotita - granada - silli manita - andalusita

(17) granada - biotita - quartzo - estaurolita - sil1 i manita - turmalina + sulfetos + grafita

(18) biotita - quartzo - estaurolita - almandina - sillimanita - grafita

(19) cordierita - biotita - granada - estaurolita (cordierita cloritizada)

As trēs üttimas associações provēm de SCARPELLI (1968).

Em rochas mais silicäticas encontraram-se:

(20) quartzo - plagiocläsio - muscovita - sillimanita (21) muscovita - turmalina - quartzo - plagiocläsio - grafita

(22) quartzo - plagiocläsio - biotita - clorita - cordierita

A estaurolita è um mineral importante presente em vă rias associações observadas. Reações que envolvem o desaparec mento da estaurolita se dão a temperaturas mäximas superiores a 
$700^{\circ} \mathrm{C}$, dependendo dos minerais a ela associados. Quando a estau rolita está associada à muscovita e ao quartzo temos a seguinte reação significativa:

(a) estaurolita + muscovita + quartzo = biotita + $+\mathrm{Al}_{2} \mathrm{SiO}_{5}+\mathrm{H}_{2} \mathrm{O}$.

Essa reação, se considerarmos uma $T \cong 675^{\circ} \pm 15^{\circ} \mathrm{C}$, ocor re à pressão total de aproximadamente $5,5 \mathrm{~kb}$.

A pressões mais elevadas encontra-se a seguinte reação:

(b) estaurolita + muscovita + quartzo $=\mathrm{Al}_{2} \mathrm{SiO}_{5}+$ + almandina + biotita $+\mathrm{H}_{2} \mathrm{O}$ (THOMPSON \& NORTON, 1968).

Se a muscovita não está presente, a estaurolita persis te a té temperaturas mais elevadas, destacando-se as seguintes reạções:

Biotita associada à estaurolita e quartzo

(c) estaurolita + biotita + quartzo = cordierita + gra nada + muscovita $+\mathrm{H}_{2} \mathrm{O}$ que ocorre a temperaturas mais elevadas que $675 \pm 15^{\circ} \mathrm{C}$ (HOFFER, 1975).

(d) estaurolita + quartzo $=\mathrm{Al}_{2} \mathrm{SiO}_{5}+$ almandina + cor dierita

(e) estaurolita + quartzo $=\mathrm{Al}_{2} \mathrm{SiO}_{5}+$ almandina $+\mathrm{H}_{2} \mathrm{C}$

Esta ūitima reação se dā a uma temperatura de $700^{\circ} \mathrm{C}$ a $P=5 \mathrm{~Kb}$ sendo apenas ligeiramente dependente da pressão.

Nas paragêneses encontradas nas encaixantes metapeli ticas de Serra do Navio, a estaurolita está geralmente associa da à biotita, quartzo, granada e sillimanita indicando uma tem peratura superior a $675^{\circ} \mathrm{C}$ para pressões de $5,5 \mathrm{~Kb}$ segundo as reações (b) e (e).

Tambëm foi observada a cordierita coexistindo com gra nada, biotita e estaurolita. Segundo a reação (c), essa associação ocorre a temperaturas superiores a $675^{\circ} \mathrm{C}$.

As paragêneses das rochas metapeliticas em geral en 
contram-se entre os equilíbrios das reações:

$$
\begin{aligned}
& \text { estaurolita + muscovita + quartzo = sillimanita + bio } \\
& \text { tita }+\mathrm{H}_{2} \mathrm{O} \text { (HOSCHEK, 1969) } \\
& \text { muscovita + quartzo }=\text { sillimanita }+\mathrm{K} \text { feldspato }+\mathrm{H}_{2} \mathrm{O} \\
& \text { (CHATTERJEE \& JOHANNES, 1974) } \\
& \text { estaurolita + quartzo }=\text { sillimanita + granada }+\mathrm{H}_{2} \mathrm{O} \\
& \text { (RICHARDSON, 1968). } \\
& \text { Excetuando-se a verossemelhança da segunda reação pe }
\end{aligned}
$$
10 fato de ter-se plagiocläsio em Serra do Navio mais comumente que feldspato alcalino, as paragêneses indicam que o pico do me tamorfismo pode ser estabelecido à temperaturas de $700 \pm 30^{\circ} \mathrm{C}$ e pressão total de $5,5 \pm 1 \mathrm{~Kb}$ (Figura 16).

Ao lado desses dados temos ainda a coexistēncia de cordierita e almandina ao lado de sillimanita, quartzo e bioti ta, associação que foi estudada por HENSEN (1971), HENSEN \& GREEN (1971, 1972 e 1973) e CURRIE,(1971). Essa associação è apenas possivel à altas temperaturas e dentro de um restrito in tervalo de pressões.

De acordo com os autores citados, a razão Feo/Feo + + Mgo da rocha é responsável pela posição e largura da faixa di variante no plano $P$, $T$, na qual coexistem granada e cordierita. Se essa razão decresce, aumenta a pressão de formação da grana da e a cordierita persiste até pressões mais elevadas, ou seja, a faixa divariante no plano $P$, T onde coexistem cordierita e granada, se desloca na direção de pressões mais elevadas quando as composições se tornarem mais ricas em magnēsio.

GIRARDI, COUTINHO \& VALARELLI (1965) determinaram o valor dessa relação para cordieritas de Serra do Navio como sen do aproximadamente 0,4 .

Segundo CURRIE, 1971 (Figura 17) tal cordierita esta em equilíbrio à $700^{\circ} \mathrm{C}$ com granada de relação FeO/FeO + Mgo= $=0,85, \bar{a}$ pressão de aproximadamente $5,5 \mathrm{~kb}$.

Essas condições são concordantes com as obtidas ou es 


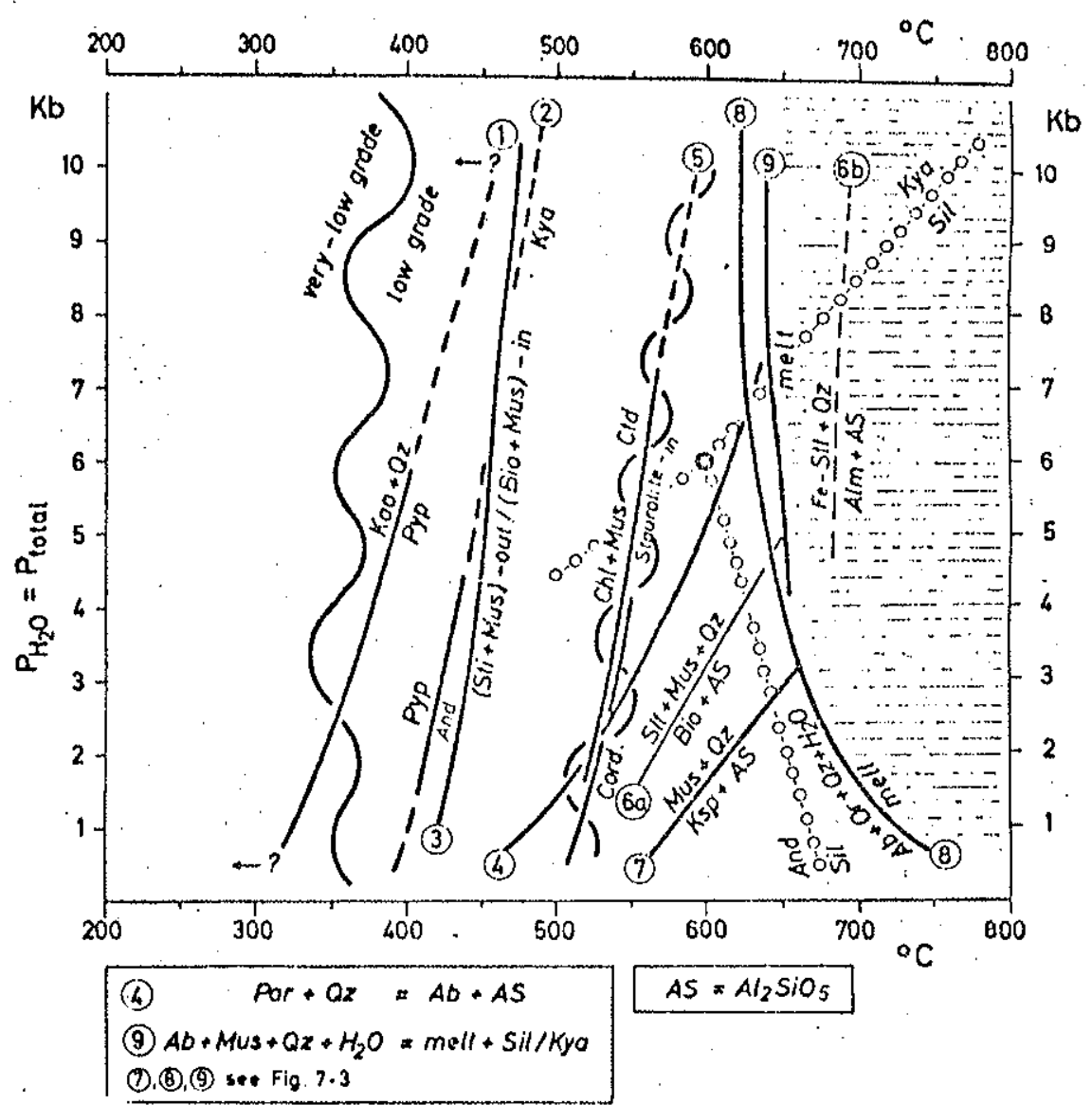

igura 16 - Diagrama $\mathrm{P}-\mathrm{T}$ : reações metamōrficas em rochas peliticas - Segundo WINKLER, 1976.

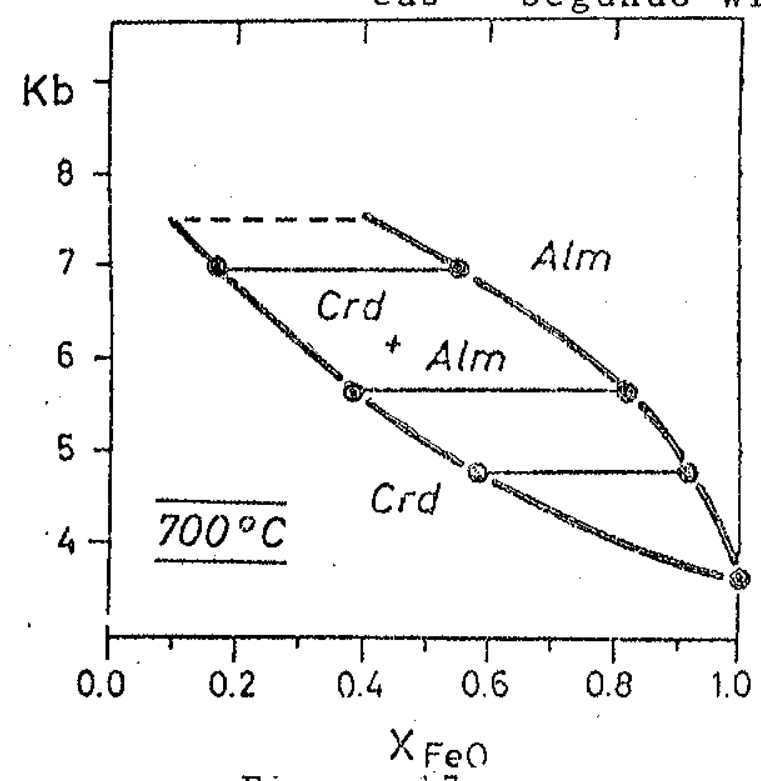

Figura 17

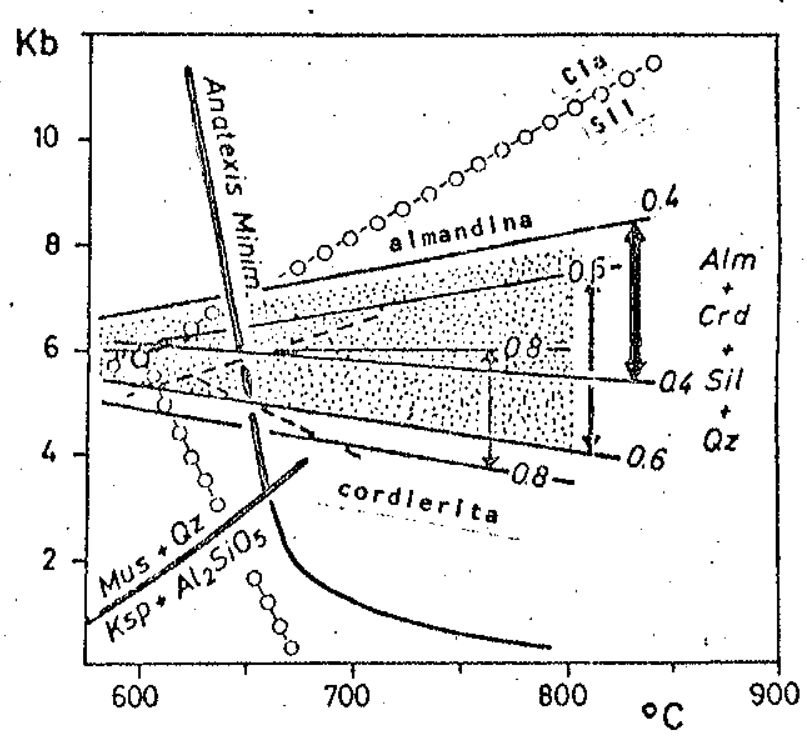

Figura 18

Figura 17 - Diagrama $P-X_{F e 0}$ de granadas e cordieritas coexisten tes na presença de sillimanita e quartzo a $700^{\circ} \mathrm{C}$ Segundo CURRIE, 1971 in WINKLER, 1976.

Figura 18 - Diagrama $P-T$ para a associação cordieritatalmandina + sillimanita + quartzo para värios valores da rela ção Feo/Feo+MgO de composição total - Segundo WIN KLER, 1976. 
timadas por outras paragêneses, mesmo que seja desconhecida a composição total da amostra em termos de Feo/Feo + MgO (Figura 18).

As diversas parageneses estudadas indicam que o pico do metamorfismo pode ser estabelecido à temperatura de $700 \pm$ $30^{\circ} \mathrm{C}$ e pressão total de $5,5 \pm 1 \mathrm{~Kb}$.

Essas condições de $P$, $T$ são suficientes para provocar migmatização, pegmatitização e palingênese. Assim, os mencio nados pegmatitos e granitos sintectōnicos (SCARPELLI e.t. al., 1963, 1968, 1973) devem ter origem anatëctica.

Inümeras associações demonstram os fenômenos de migma tização com formação de fases graniticas: quartzo - muscovita - plagioclásio e turmalina, e como acessörios zircão, grafita, sulfetos e titanita.

Vārios indīcios de uma segunda fase metamōrfica foram observados principalmente nas rochas encaixantes. Esta segunda fase esta bem caracterizada nas rochas peliticas onde se obser va, comumente, a formação de andalusita de segunda geração a partir de sillimanita (Foto 60). Algumas vezes observa-se a for mação de andalusita associada a microclīnio (ou muscovita e quartzo) a partir de sillimanita e ortoclásio (Fotos 60 e 61), bem como sillimanita e biotita transformando-se em cordierita e muscovita (Foto 63). Nas rochas calcossilicatadas o principal indício deste segundo metamorfismo è a transformação de diops dio + feldspato potássico em flogopita + calcita (Foto 64).

Este metamorfismo pode ser caracterizado como de grau mëdio, fácies anfibolito sob condições semelhantes às ocorridas em Buritirama, e com valores de $\mathrm{X}_{\mathrm{CO}_{2}}$ bem inferiores às do pri. meiro metamorfismo.

Ligadas ou consequentes a esta fase, vārias outras transformações "retrometamörficas" ou de ação de remobilização de soluções foram observadas, tanto nos protominérios como nas rochas encaixantes: 
rodocrosita + rodonita cortada por veios de quartzo,al bita e Mn-anfibólio, este ūitimo formado por alteração do piroxé nóide;

$$
\text { rodonita transformando-se em Mn-anfibōlio + rodocrosi }
$$

ta;

$$
\begin{aligned}
& \text { tefroita + rodocrosita + granada, cortados por rodonita; } \\
& \text { tefroita + espessartita + rodocrosita + grafita sendo }
\end{aligned}
$$
anfibolitizada com o aparecimento de carbonato manganesiffero fi no;

$$
\text { cloritização de plagioclásios de rochas calco-silica }
$$
ticas e de cordierita e biotita de metapelitos; bem como, trans formação de sillimanita em andalusita ou biotita nas rochas meta. peliticas (Fotos $35,36,37,40,51,44,46,48$ ). 
V - 3 - PARTIÇÃO DE ELEMENTOS

Nas Figuras 7 e 11 os dados de microssonda dos piroxe nöides, olivinas, carbonatos e clinopiroxênios de Buritirama e de Serra do Navio são plotados em diagrama triangular com vérti ces $(\mathrm{Mn})$ - $(\mathrm{Ca})-(\mathrm{Mg}+\mathrm{Fe})$ em porcentagem molar. A simbologia indica a coexistência entre as fases numa mesma lâmina.

Os dados desses diagramas ressaltam mais uma vez a in fluência da composição dos carbonatos no tipo de piroxenóide man ganesifero coexistente. Alëm disso são observados os "trends"dé composição dos diferentes minerais considerados. Esses diagra mas indicam que as tefroitas são magnesianas, denominadas por alguns autores de picrotefroita. Os dados de composição dos pi roxenōides (rodonita e piroxmangita), coincidem com as anālises de minerais semelhantes tabelados em DEER, ROWIE \& ZUSSMAN (1963). Nota-se uma diferença entre os "trends" de carbonatos de Buriti rama e de Serra do Navio que serā comentada mais adiante. Alëm disso observa-se que os clinopiroxēnios coexistem com rodonitas e carbonatos pobres em manganēs. Sem analisar os "gaps" de com posição dos carbonatos, pode-se dizer que eles constituem uma so lução sölida entre mangano-calcita e mangano-kutnahorita, ambas magnesianas (com pouco de Fe).

A Figura 19 mostra a distribuição, em peso por cento de cätions, de $\mathrm{Ca}^{2+} / \mathrm{Ca}^{2+}+\mathrm{Mn}^{2+}+\mathrm{Mg}^{2+}+\mathrm{Fe}^{2+}$ entre carbonatos e es pessartitas coexistentes. Nota-se que existe uma lei de distri buição regular entre os dois minerais analisados a menos de uma ligeira dispersão dos pontos na região de carbonatos pobres em cálcio. A granada, provavelmente formou-se a partir da reação entre carbonato manganesifero, silica e filossilicatos,do tipo:

$12\left(\mathrm{Mn}_{\mathrm{x}} \mathrm{Ca}_{\mathrm{y}} \mathrm{Mg}_{z} \mathrm{Fe}_{\mathrm{W}}\right) \mathrm{CO}_{3}+2 \mathrm{SiO}_{2}+\mathrm{Al}_{4} \mathrm{Si}_{4}{ }_{10}(\mathrm{OH})_{8}=$

$=2\left(\mathrm{Mn}_{p} \mathrm{Ca}_{q} \mathrm{Mg}_{r} \mathrm{Fe}_{s}\right)_{3} \mathrm{Al}_{2} \mathrm{Si}_{3} \mathrm{O}_{12}+6\left(\mathrm{Mn}_{x-p} \mathrm{Ca} y-q \mathrm{Mg}_{z-r} \mathrm{Fe}_{w-s}\right) \mathrm{CO}_{3}+4 \mathrm{H}_{2} \mathrm{O}+6 \mathrm{CO}_{2}$ 
A dispersão de pontos observada na distribuição de ele mentos entre espessartita e carbonato pode ser devida a cresci mento porfiroblástico e zonado das granadas que muitas vezes pos suem inclusões poiquiliticas do carbonato original, tendendo a equilibrios parciais seja durante o metamorfismo progressivo, quanto durante o metamorfismo retrögrado ou metamorfismo poste rior de mais baixo grau.

Nas Figuras 20 e 27 são vistas as distribuições $\mathrm{Ca}^{2+} / \Sigma$ cātions bivalentes $\left(\Sigma M^{2+}\right.$ ) entre carbonatos e piroxenōides coexis tentes: rodonita ou piroxmangita. Nota-se que existem leis de distribuição regular do tipo potencial, do cālcio entre o carbo nato e os piroxenóides, independentemente do fato das rodonitas de uma dada jazida serem sempre mais ricas nesse elemento do que as piroxmangitas.

A regularidade dessas distribuições indicam que as fa ses consideradas estão em equilỉbrio, destacando-se para a forma ção dos piroxenōides a seguinte reação:

$2\left(\mathrm{Mn}_{x} \mathrm{Ca}_{y} \mathrm{Mg}_{z} \mathrm{Fe}_{w}\right) \mathrm{CO}_{3}+\mathrm{SiO}_{2}=\left(\mathrm{Mn}_{\mathrm{p}} \mathrm{Ca}_{q} \mathrm{Mg}_{r} \mathrm{Fe}_{s}\right) \mathrm{SiO}_{3}+\mathrm{CO}_{2}+\left(\mathrm{Mn}_{x-p} \mathrm{Ca} y-\mathrm{Mg} z-r \mathrm{Fe}{ }_{w-s}\right) \mathrm{CO}_{3}$

A natureza do inossilicato de cadeia simples depende da relação $\mathrm{Ca}^{2+} / \mathrm{Mn}^{2+}$ que decresce na seguinte ordem:

piroxênio > rodonita > piroxmangita

Nas figuras de distribuição mencionadas acima observa- se uma tendëncia dos pontos referentes a Serra do Navio concen trarem-se na extremidade mais pobre em Ca dos carbonatos. Em Ser ra do Navio a temperatura māxima atingida pelo metamorfismo supe rou em pelo menos $150^{\circ} \mathrm{C}$ a de Buritirama. Esses fatos sugerem uma diferenciação tērmica segundo a qual à mais altas temperaturas, os piroxenóides e a espessartita admitem relativamente mais manga nẹs e provavelmente tambēm mais $\mathrm{Fe}$ e $\mathrm{Mg}$ do que Ca.

A Figura 22 apresenta os dados de distribuição de $\mathrm{Ca}^{2+} / \Sigma \mathrm{M}^{2+}$ entre carbonatos e anfibölios manganesiferos coexisten 
tes. Embora existam poucos dados, pode-se inferir uma certa re gularidade dos pontos sugerindo equilibrios entre as fases em contato. Ao mesmo tempo nota-se uma certa constância do ca nos anfibolios, embora coexistam com carbonatos relativamente pobres nesse elemento em Serra do Navio e carbonatos mais ricos em Bur tirama.

A distribuição $\mathrm{Ca}^{2+} / \Sigma \mathrm{M}^{2+}$ entre olivinas e carbonatos coexistentes apresentou valores semelhantes e muito pequenos de vido ao constante baixo teor de cao das olivinas. A relação $\mathrm{Mn}^{2+}+\mathrm{Ca}^{2+} / \Sigma \mathrm{M}^{2+}$ mostrou-se tambëm regular para esse par de mine rais (Figura 23).

Para a formação das olivinas existem duas reações prin cipais:

$$
\begin{aligned}
& 2 M^{2+} \mathrm{CO}_{3}+\mathrm{SiO}_{2}=M_{2}^{2+} \mathrm{SiO}_{4}+2 \mathrm{CO}_{2} \\
& M^{2+} \mathrm{CO}_{3}+M^{2+} \mathrm{SiO}_{3}=M_{2}^{2+} \mathrm{SiO}_{4}+\mathrm{CO}_{2}
\end{aligned}
$$

a partir respectivamente de carbonato e quartzo ou de carbonato e piroxenōide. Essas reações diferem fundamentalmente entre si pela pressão parcial do $\mathrm{CO}_{2}$ de equilïbrio. A primeira delas ëdi ficilmente realizävel no metamorfismo progressivo de rochas car bonäticas pois a 2.000 bars, a fração molar do $\mathrm{CO}_{2}$ para o equil brio dessa reação deve ser pröxima de 0,01 , sendo que as paragê neses e alguns dados de inclusões fluidas indicam fração molar de $\mathrm{CO}_{2}$ elevada $(>0,8)$.

Essa distribuição apresenta uma certa dispersäo talvez devida ao fato de que a maioria das olivinas formou-se a partir de piroxenöide e carbonato, sendo importante considerar..se em cada caso o tipo estrutural do piroxenöide original. Alëm disso, muitas olivinas são porfiroblästicas e poiquiloblästicas.

Analisando-se as Figuras 24 e 11 , observa-se que as pi roxmangitas de Serra do Navio coexistem com carbonatos com valo 


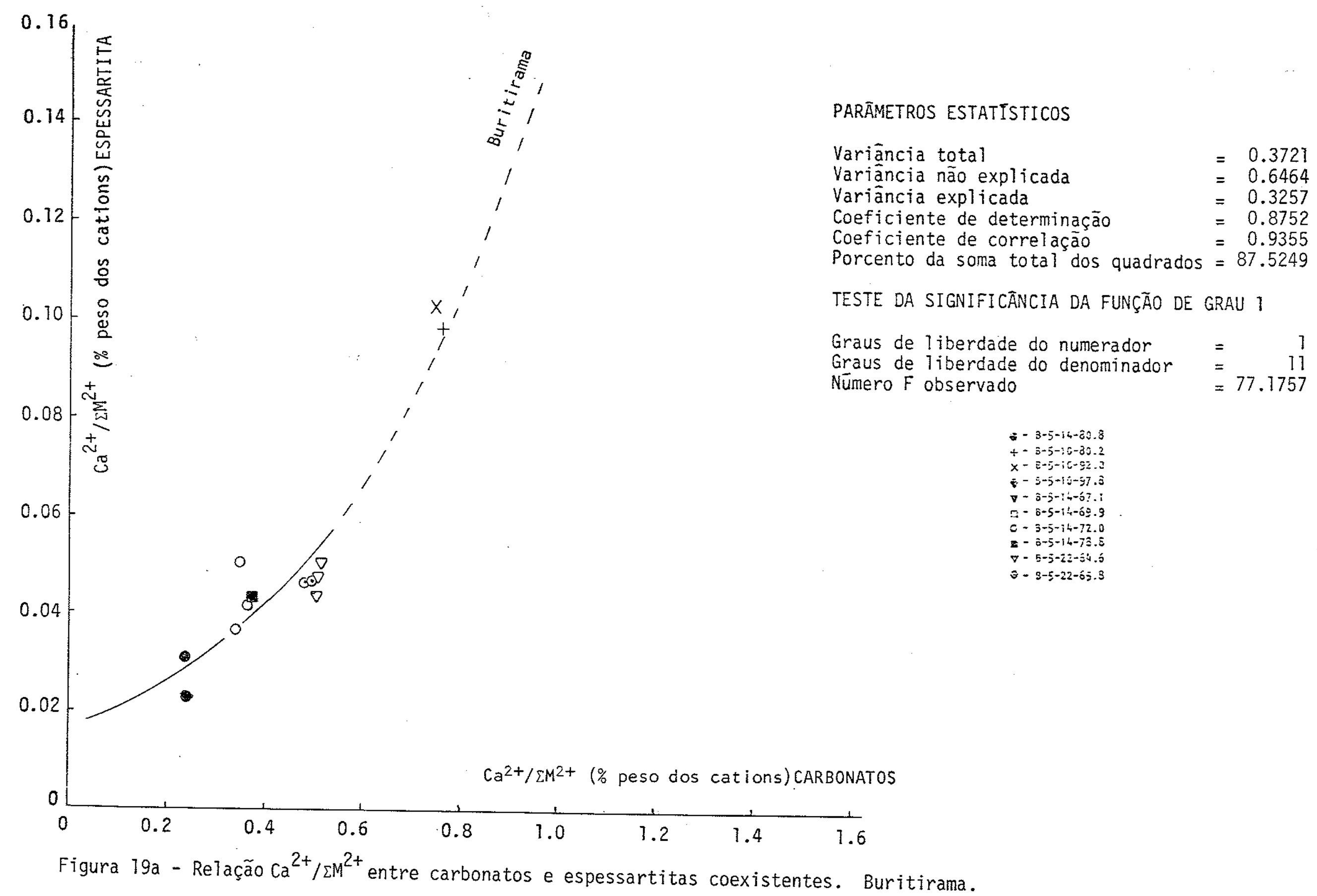




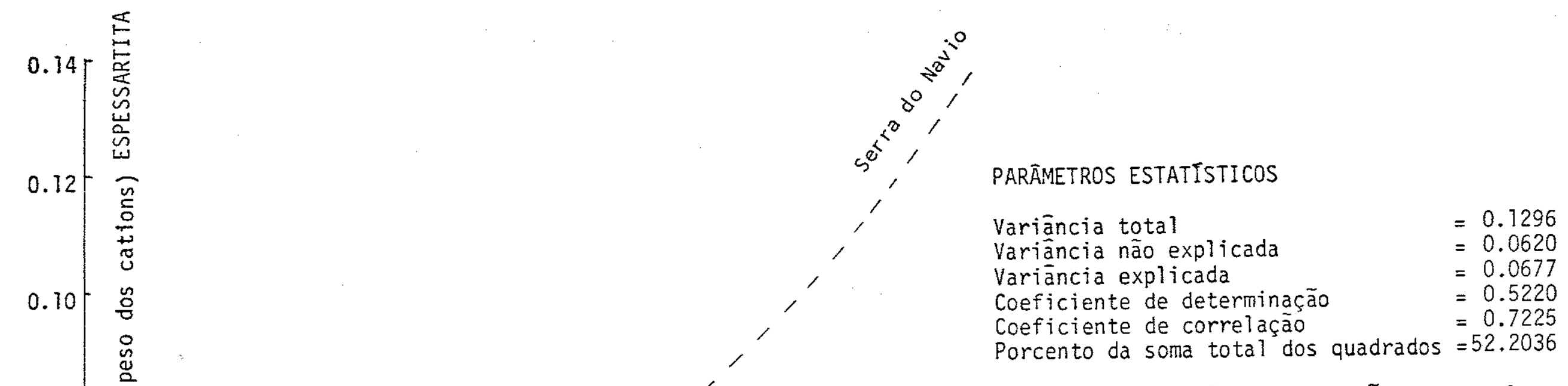

TESTE DA SIGNIFICÂNCIA DA FUNÇÃO DE GRAU 1

Graus de liberdade do numerador $=17$

$\begin{array}{rlr}\text { Graus de liberdade do denominador } & =15 \\ \text { Numero F observado } & =16.3831\end{array}$

- $E-12-76-94.8$

०- $F-12-76-122$

$0-F-12-75-11 i .7$

$+T-12-12-90.5$

(1) $c-2-37-81$

- $c-2-40-53.5$

0.02

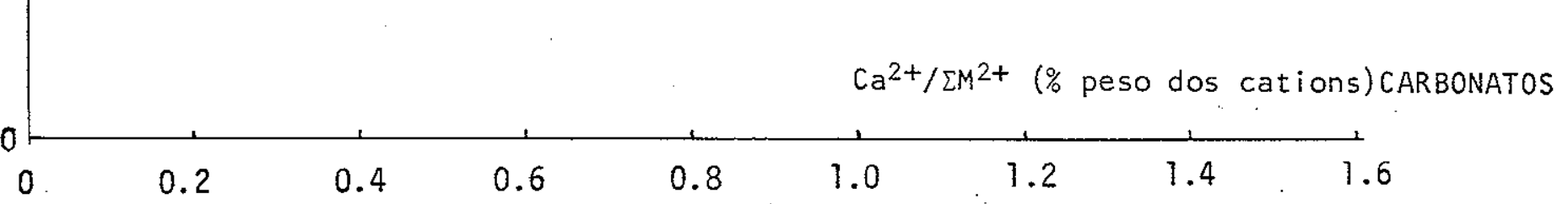

Figura $19 b$ - Relação $\mathrm{Ca}^{2+} / \mathrm{LM}^{2+}$ entre carbonatos e espessartitas coexistentes. Serra do Navio. 


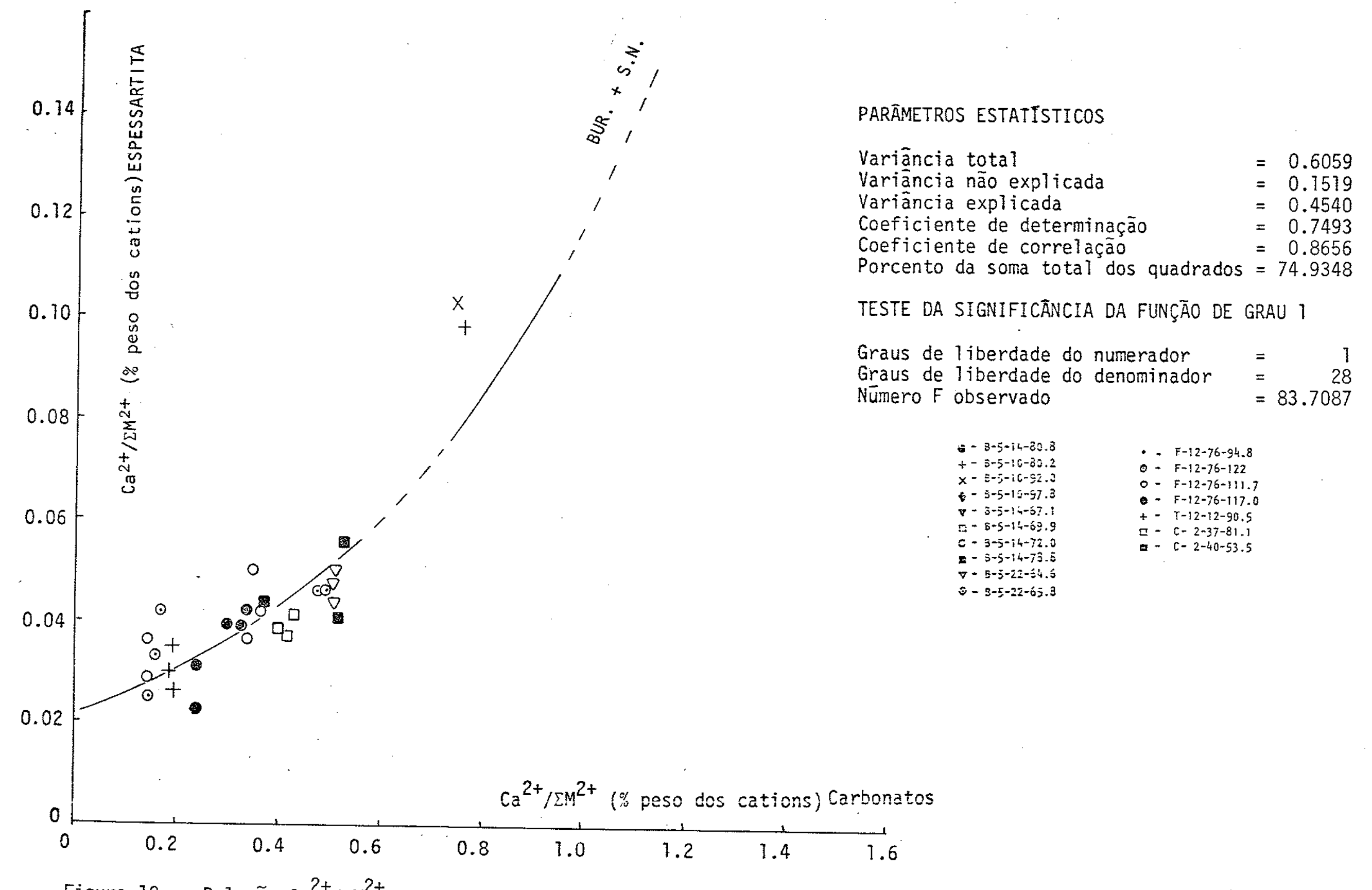

Figura $19 \mathrm{c}$ - Relação $\mathrm{Ca}^{2+} / \Sigma \mathrm{M}^{2+}$ entre carbonatos e espessartitas coexistentes. Buritirama e Serra do Navio. 


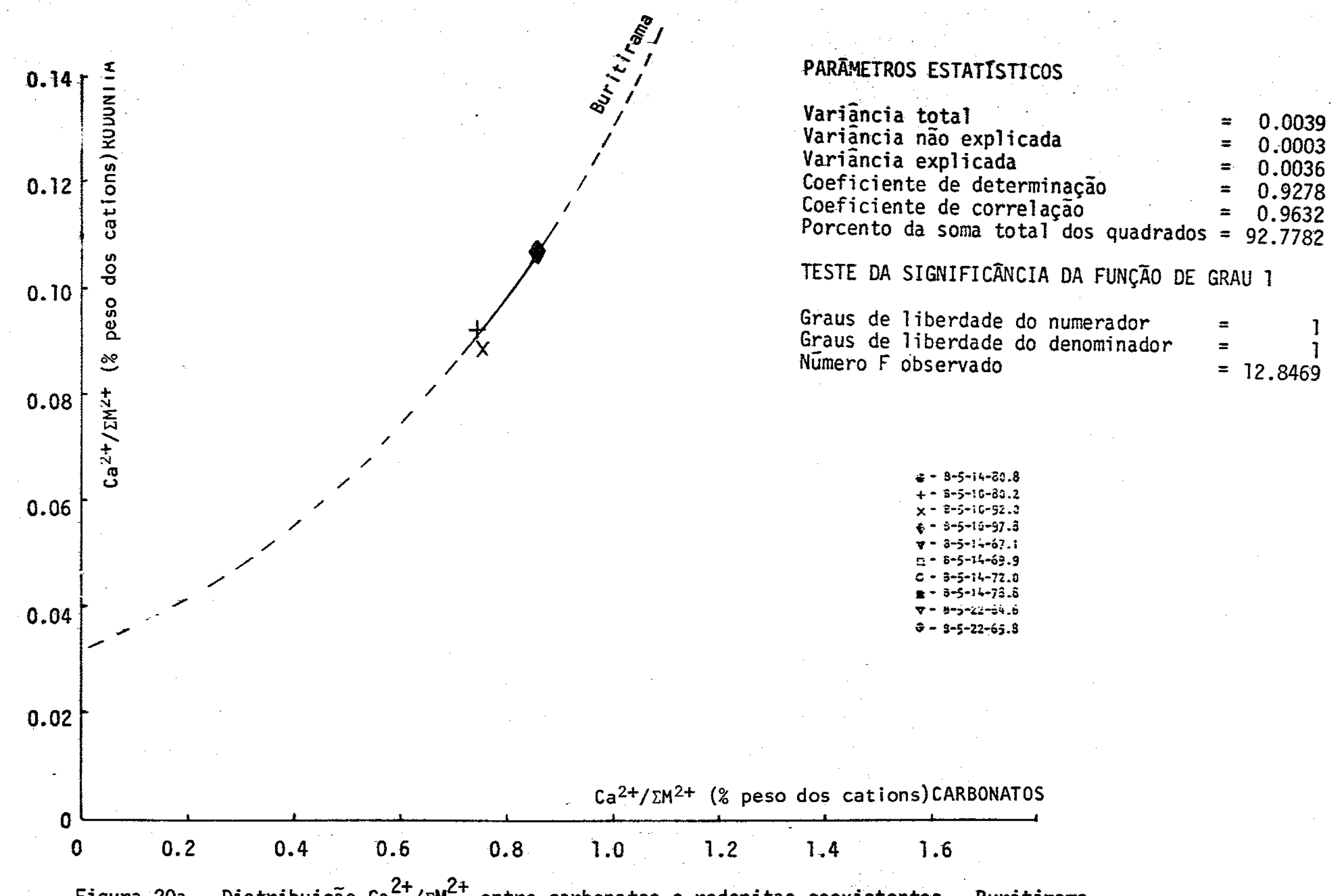

Figura 20a - Distribuição $\mathrm{Ca}^{2+} / \Sigma \mathrm{M}^{2+}$ entre carbonatos e rodonitas coexistentes. Buritirama. 


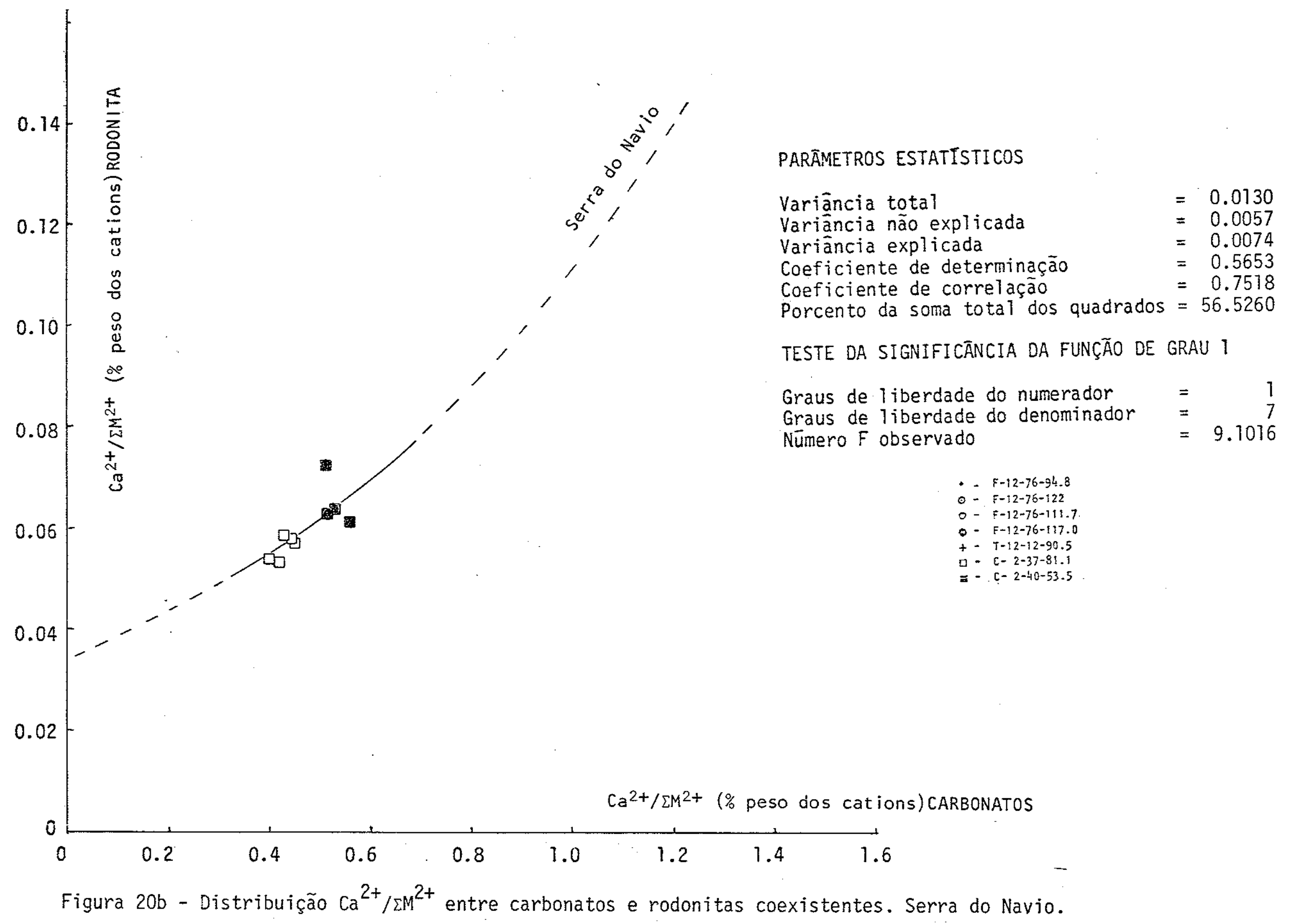




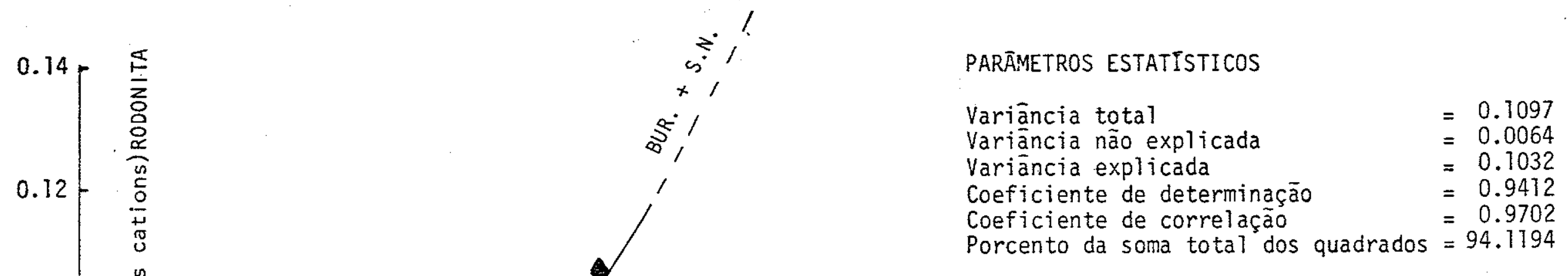

Variāncia não explicada

Variäncia explicada

TESTE DA SIGNIFICÃNCIA DA FUNÇĀO DE GRAU 1

Graus de liberdade do numerador =

$\begin{array}{rlr}\text { Graus de liberdade do denominador } & =10 \\ \text { Nümero F observado } & =160.0517\end{array}$

\begin{tabular}{|c|c|}
\hline & \\
\hline$=-3-5-i 4-60.8$ & $\therefore \quad F-12-76-94.8$ \\
\hline $\begin{array}{l}+-3+5-10-60.3 \\
-\equiv-5-i c-52.2\end{array}$ & $0=F-12-76-122$ \\
\hline $\begin{array}{l}5-5-i 6-52.2 \\
3-5-1 j-57.3\end{array}$ & $0: F-12-76-111.7$ \\
\hline 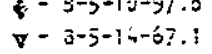 & $F-12+76-117.0$ \\
\hline$-8-5-1 \div-60.9$ & $\begin{array}{l}+T-12-12-90.5 \\
\end{array}-[-2-37-8]$ \\
\hline$-5-5-14-72.0$ & $-2-40-53.5$ \\
\hline $\begin{array}{l}3-5-14-73.5 \\
E-5+23-54.6\end{array}$ & \\
\hline$+2<-34.0$ & \\
\hline
\end{tabular}

$\mathrm{Ca}^{2+} / \Sigma^{2+}$ (\% peso dos cations)CARBONATOS

0.2

0.4

0.6

0.8

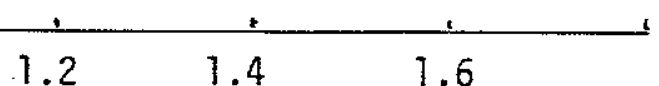

Figura 20c - Distribuição $\mathrm{Ca}^{2+} / \Sigma \mathrm{M}^{2+}$ entre carbonatos e rodonitas coexistentes. Buritirama e Serra do Navio. 


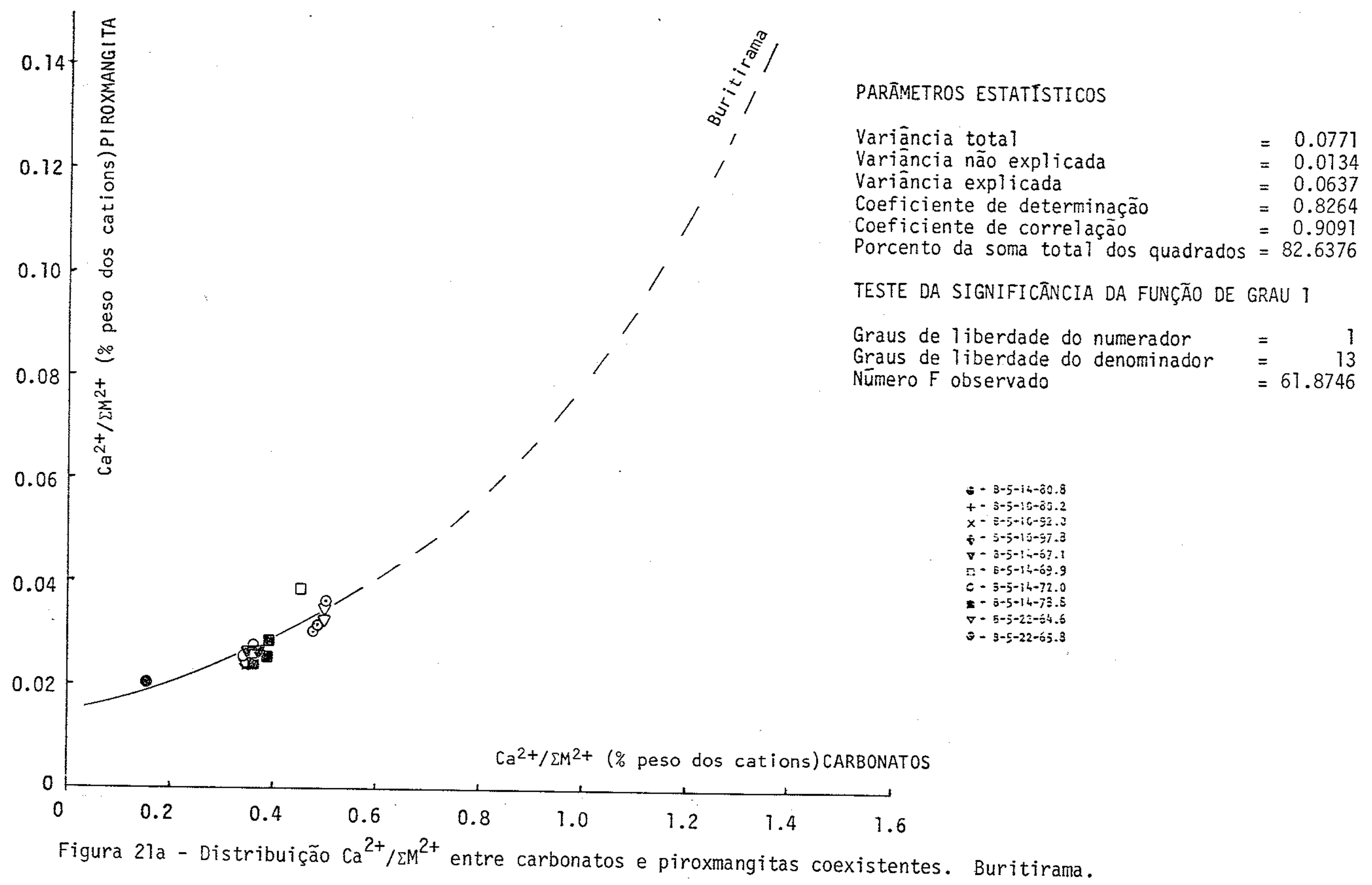




\subsection{6}

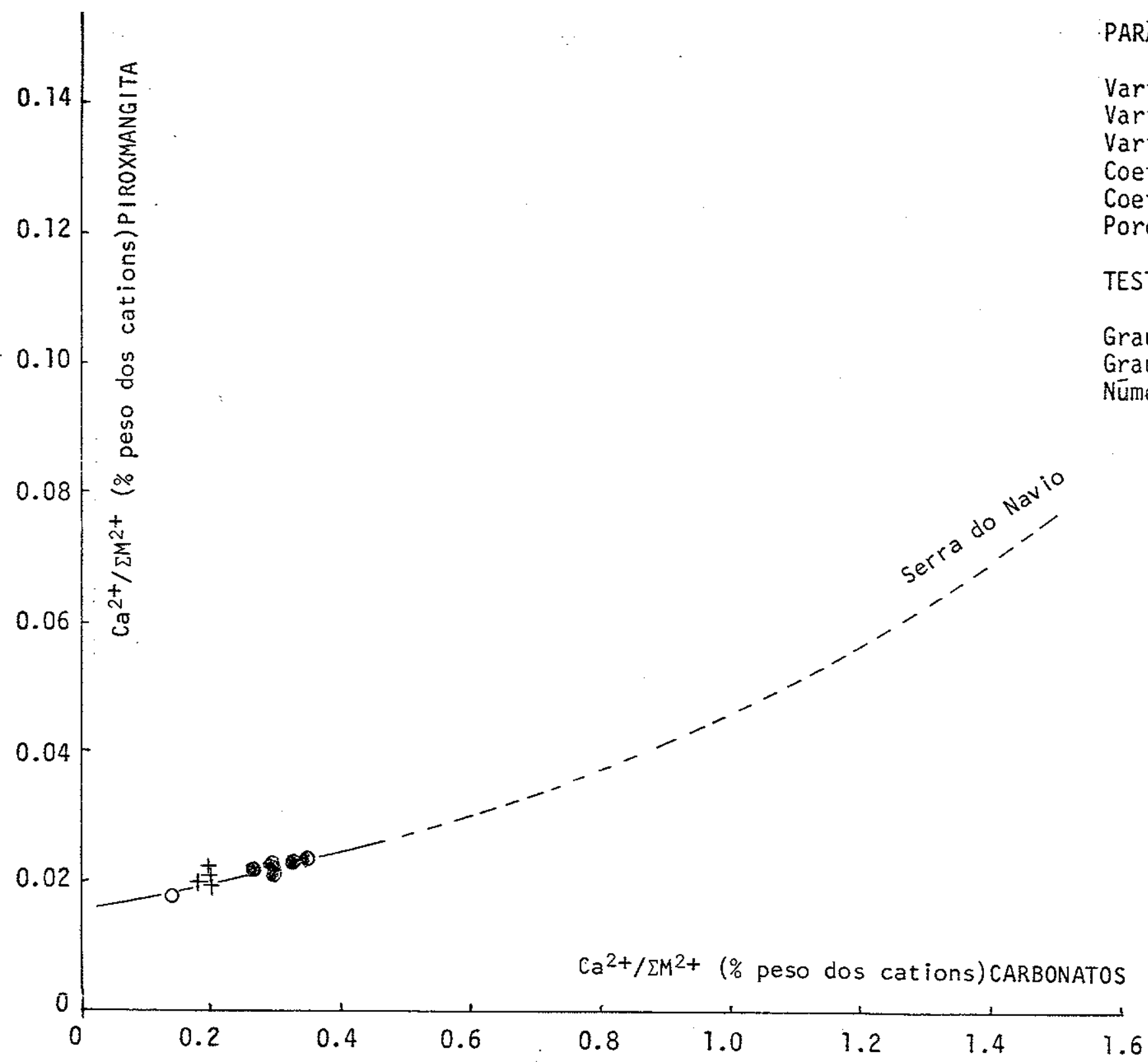

PARÂMETROS ESTATISTICOS

Variäncia total

Variäncia não explicada

Variancia explicada

Coeficiente de determinação

Coeficiente de correlação

Porcento da soma total dos quadrados $=69.5129$

TESTE DA SIGNIFICÂNCIA DA FUNÇÃO DE GRAU 1

Graus de liberdade do numerador

Graus de liberdade do denominador

Numero $F$ observado

$$
\begin{aligned}
& =\quad=12-76-94.8 \\
& 0=8-12-76-122 \\
& 0=\quad=-12-75-111.7 \\
& 0=\quad=-12-76-117.0 \\
& +=7-12-12-90.5 \\
& 0=[-2-37-81.1 \\
& =c-2-40-53.5
\end{aligned}
$$

$=0.0126$

$=0.0038$

$=0.0087$

$=0.6951$

0.8337

Figura $21 \mathrm{~b}$ - Distribuição $\mathrm{Ca}^{2+} / \Sigma \mathrm{M}^{2+}$ entre carbonatos e piroxmangitas coexistentes. Serra do Navio. 


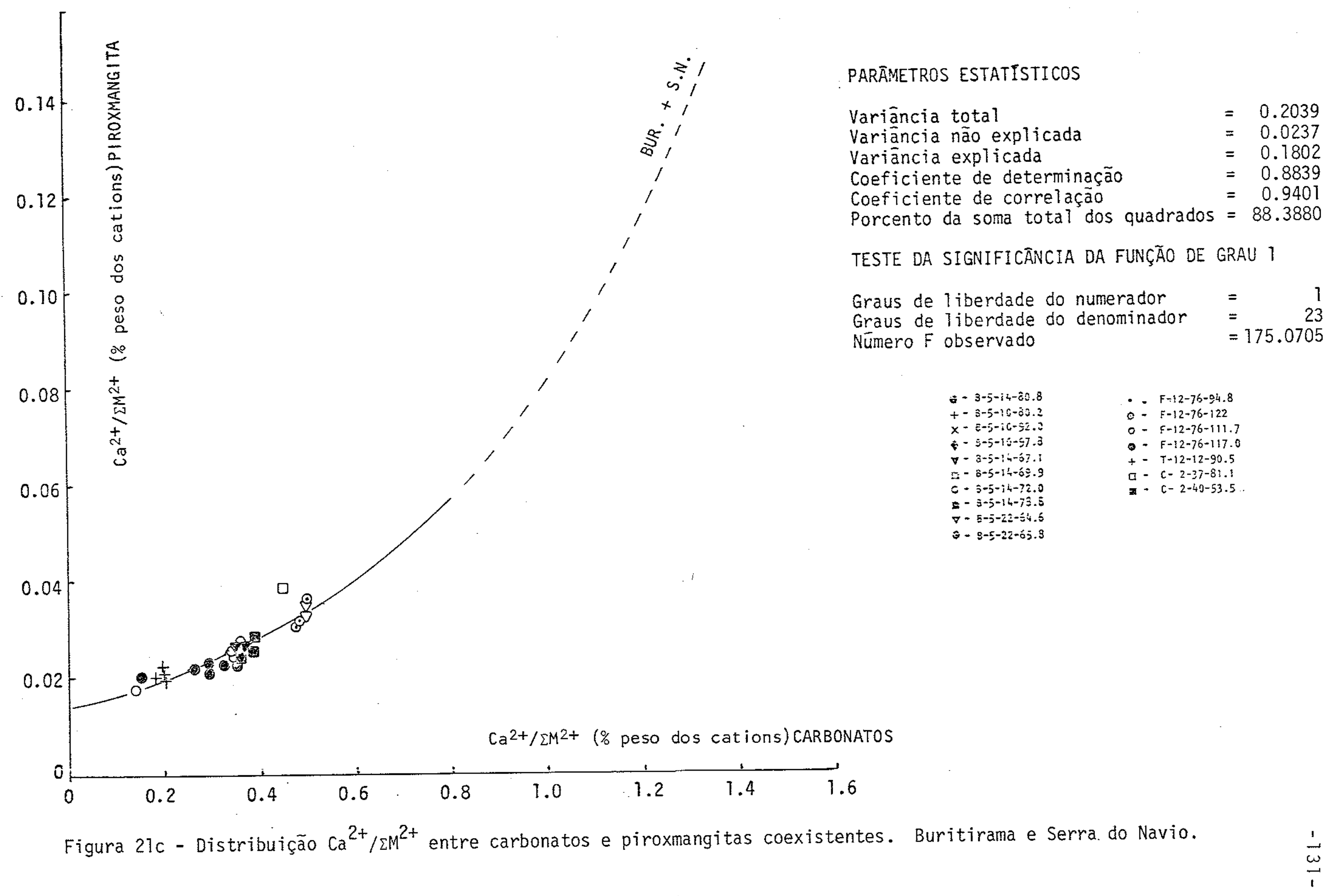




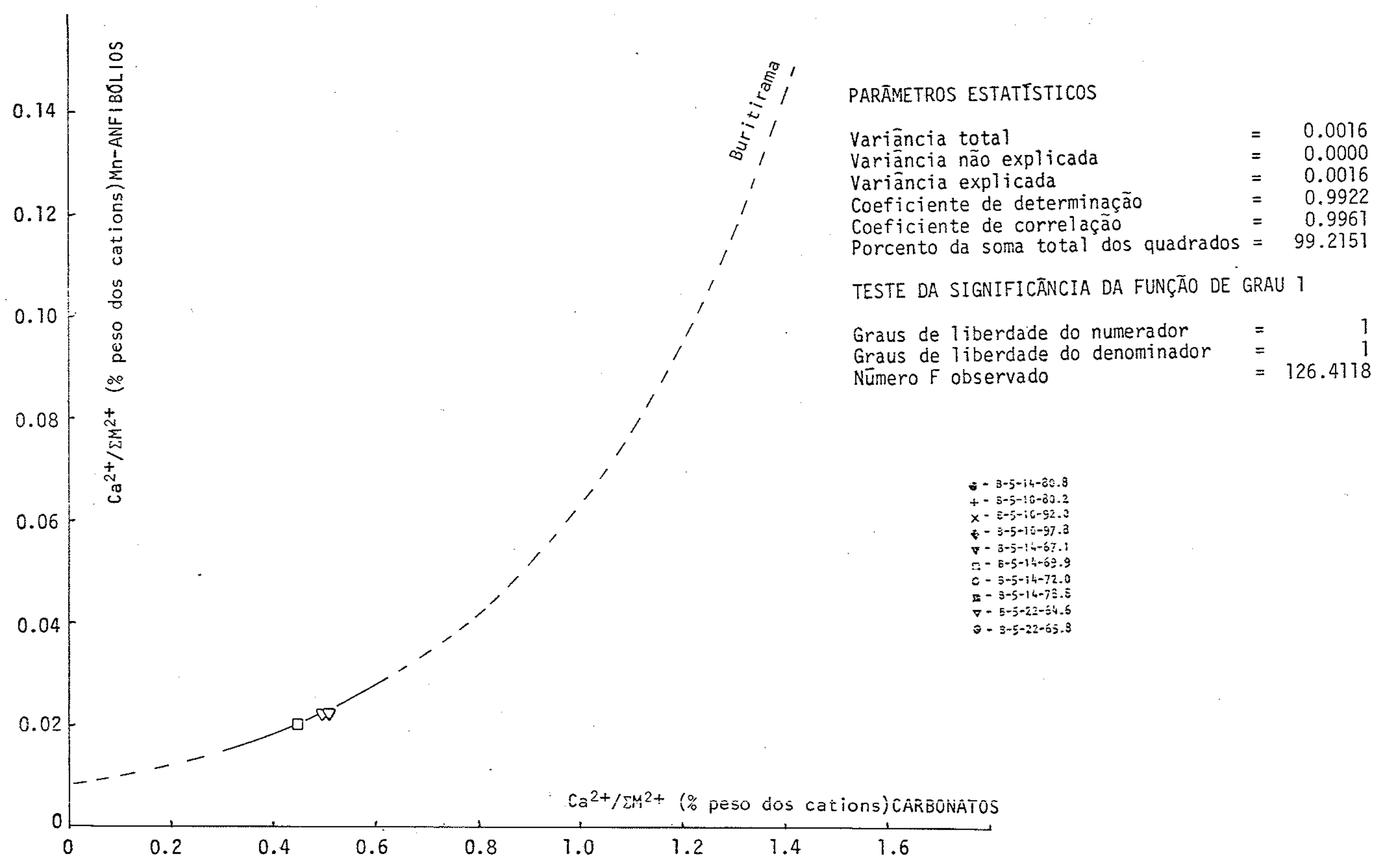

Figura 22a - Distribuição $\mathrm{Ca}^{2+} / \mathrm{LM}^{2+}$ entre carbonatos e anfibōlios manganesiferos coexistentes. Buritirama. 
PARĀMETROS ESTATISTICOS

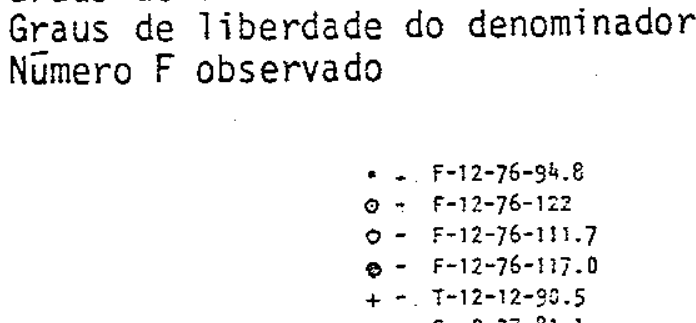
Graus de liberdade do denominador Numero $F$ observado

$=0.0055$

$=0.0011$

$=0.0044$

$=0.7954$

$=0.8919$

79.5427
Figura 22b - Distribuição $\mathrm{Ca}^{2+} / \Sigma \mathrm{M}^{2+}$ 


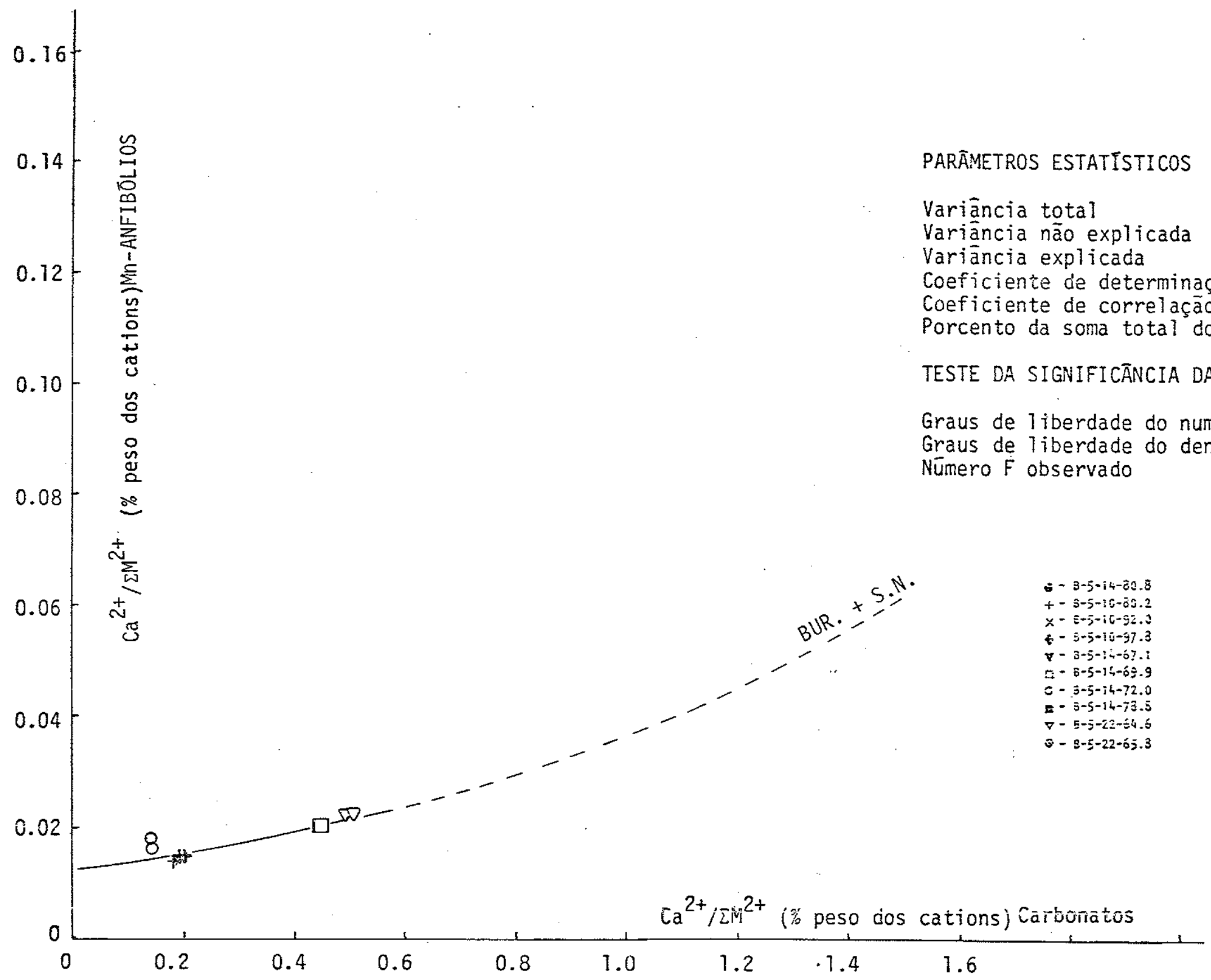

Figura 22C - Distribuição $\mathrm{Ca}^{2+} / \Sigma^{2+}$ entre carbonatos e anfibōlios manganesiferos coexistentes. Buritirama e Serra do Navio. 
PARĀMETROS ESTATISTICOS

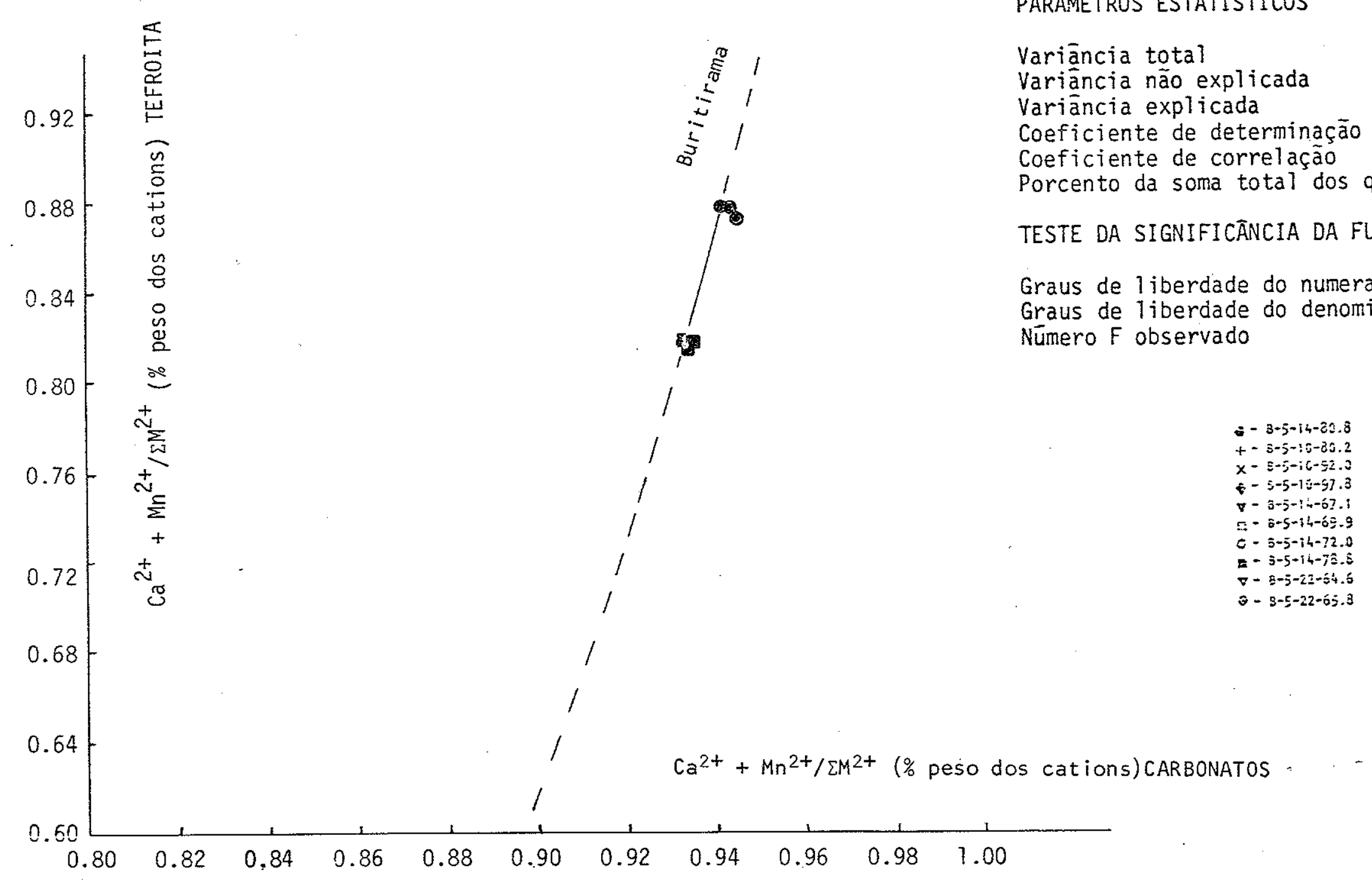

Figura 23a - Distribuição $\mathrm{Ca}^{2+}+\mathrm{Mn}^{2+} / \mathrm{\Sigma M}^{2+}$ entre carbonatos e tefroitas coexistentes. Buritirama. 


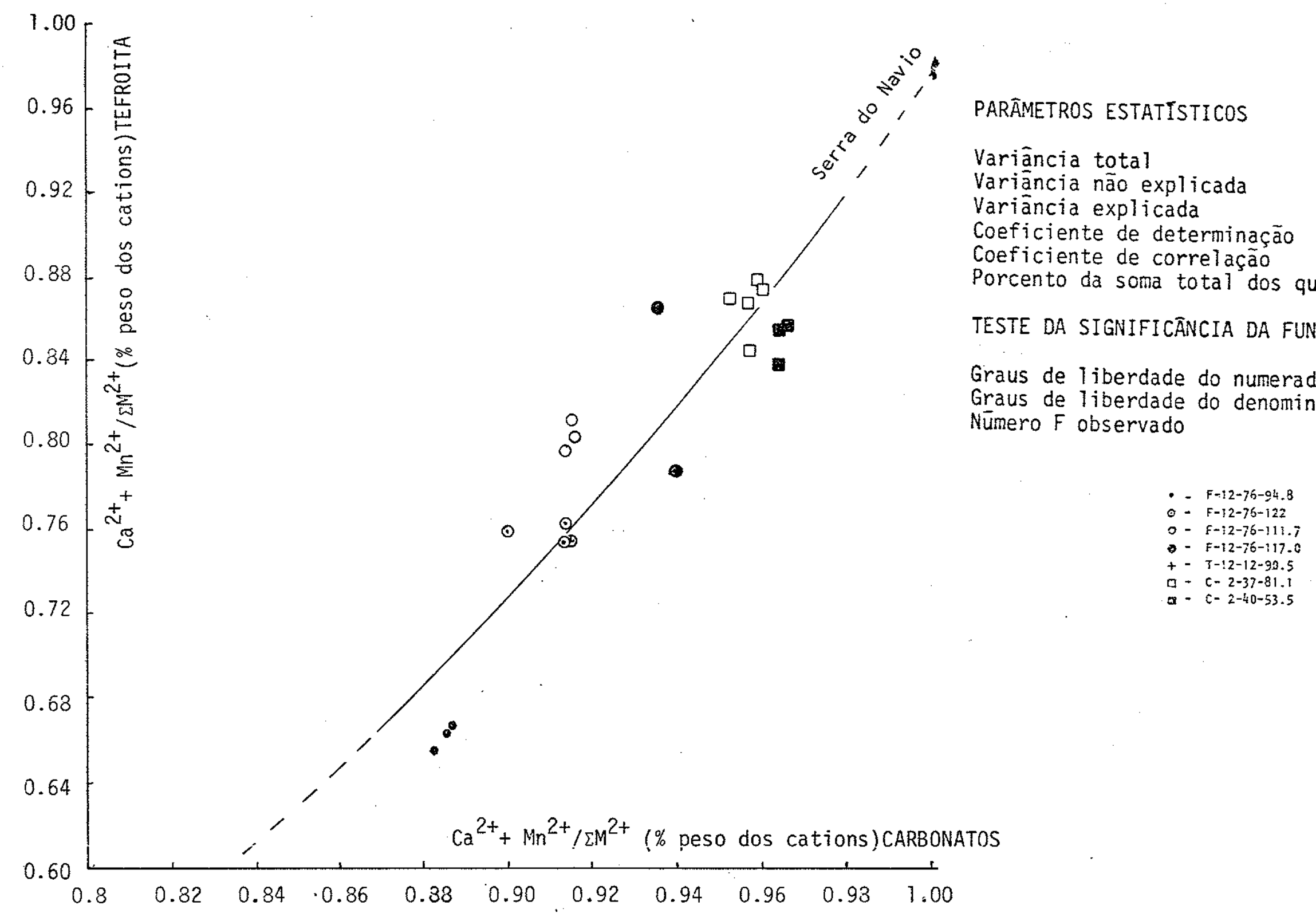

Figura 23b - Distribuição $\mathrm{Ca}^{2+}+\mathrm{Mn}^{2+} / \Sigma \mathrm{M}^{2+}$ entre carbonatos e tefroitas coexistentes. Serra do Navio: 


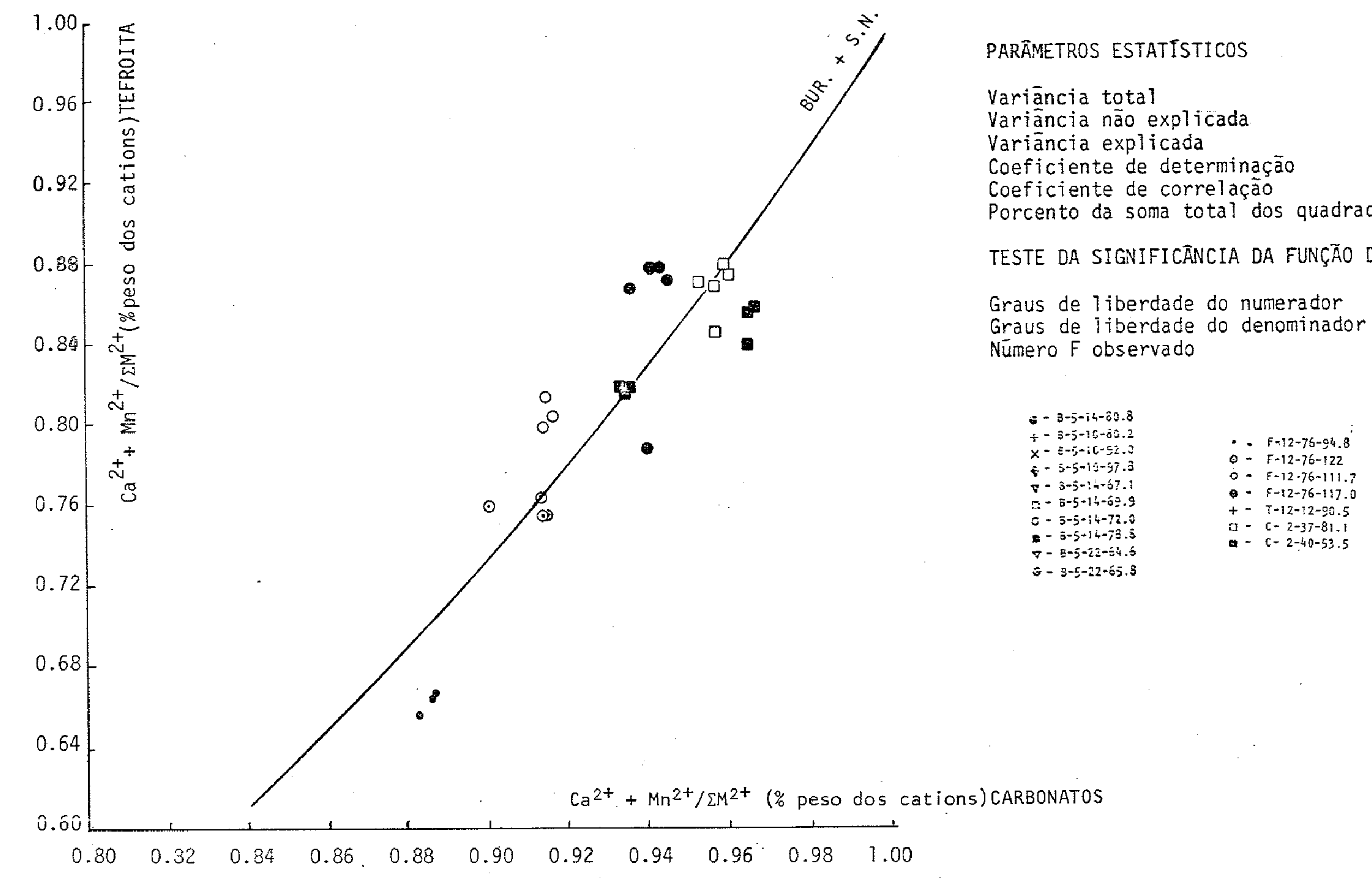

Figura $23 \mathrm{C}$ - Distribuição $\mathrm{Ca}^{2+}+\mathrm{Mn}^{2+} / \mathrm{LM}^{2+}$ entre carbonatos e tefroitas coexistentes. Buritirama e Serra do Navio.

$=0.0361$

$=0.0078$

$=0.0283$

$=0.7843$

$=0.8856$

78.4277

\section{TESTE DA SIGNIFICÃNCIA DA FUNÇÃO DE GRAU 1}

Graus de liberdade do numerador Graus de Tiberdade do denominador $\begin{array}{ll}= & 1 \\ = & 25\end{array}$ $=90.8894$

Figura 23 c - Distribuição Cazt + Mn $/ 2 M$ entre carbonatos e tetrot tas coe. 


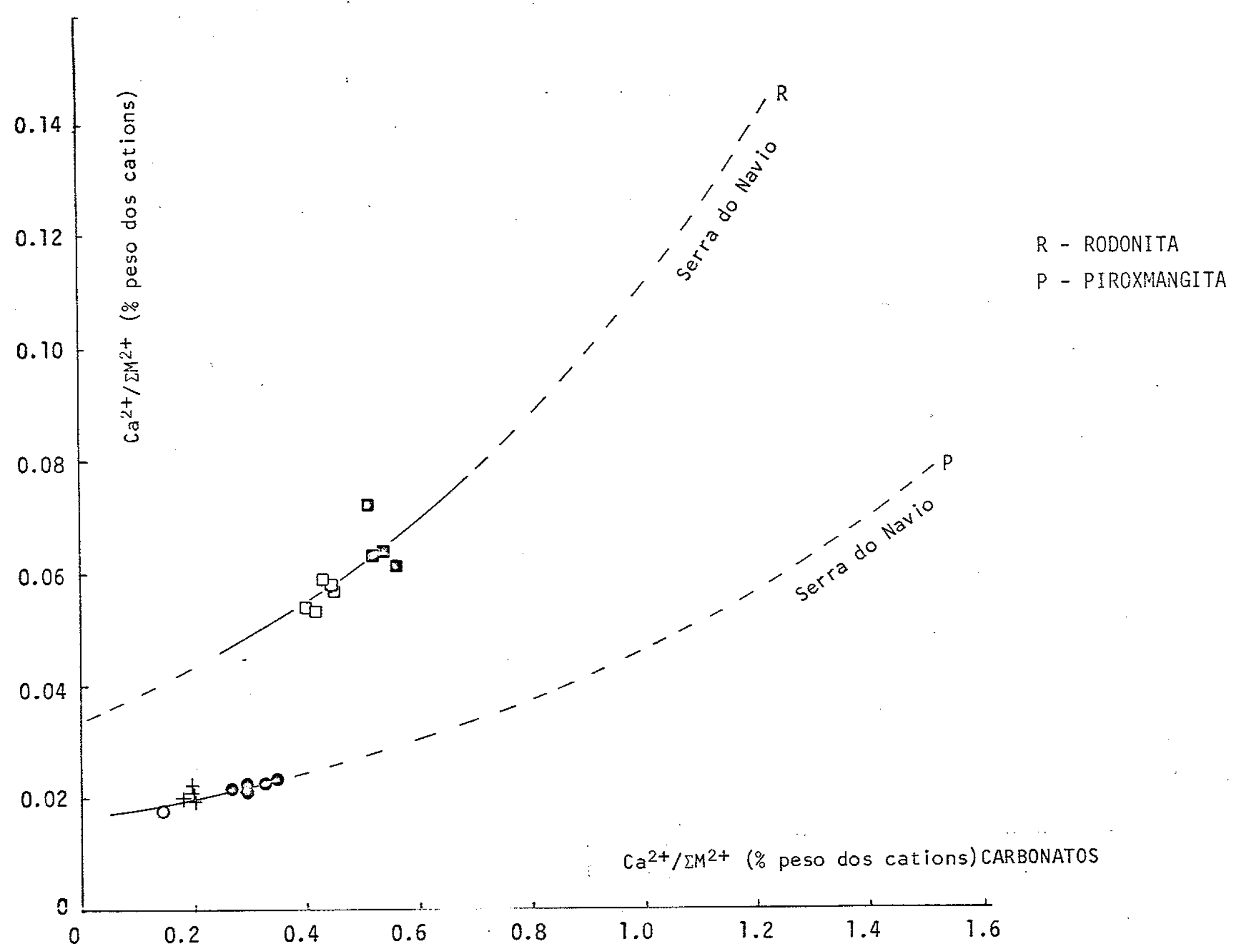

- $=5-12-75-94.8$ o - $=-12-76-122$ - $5-12-76-111.7$ T-12-12-90.5 ㄷ. - $5-2-37-81.1$ . $c-2-40-53.5$

Figura 24 - Distribuição $\mathrm{Ca}^{2+} / \Sigma \mathrm{M}^{2+}$ entre carbonatos e os piroxenōides de Serra do Navio. 
res de $\mathrm{Ca}^{2+} / \Sigma \mathrm{M}^{2+}$ atë 0,35 (correspondendo a uma composiçăo $\mathrm{Mn}_{0,52}$, $\left.\mathrm{Ca}_{0,40}, \mathrm{Mg}_{0,07}, \mathrm{Fe}_{0,01} \mathrm{CO}_{3}\right)-$. Entre os valores 0,35 e 0,40 não existem piroxenóides, mas a partir de 0,40 forma-se a rodonita. $\mathrm{Na}$ Figura 26 (coexistência de carbonatos com piroxenóides de Bu ritirama) observa-se que o limite dessa relação nas piroxmangi tas é de 0,51 , e que as rodonitas formam-se somente a partir de 0,74 , existindo um "gap" entre esses valores.

Estes dados vem corroborar com o trabalho experimental de ABRECHT \& PETERS (1975) dando-1he uma interpretação dinâmica apenas sugerida pelos autores. A tolerância de substituição de Mn por Ca nas piroxmangitas depende de temperatura. Quanto me nor a temperatura, maior o limite dessa substituição (Figura 25), confirmando temperatura māxima do metamorfismo de Buritirama in ferior à de Serra do Navio. Esses fatos explicam o maior teor de Ca das piroxmangitas de Buritirama quando comparadas com as piroxmangitas de Serra do Navio. O mesmo fato $\bar{e}$ verificado quan do se comparam as rodonitas das duas ocorrências.

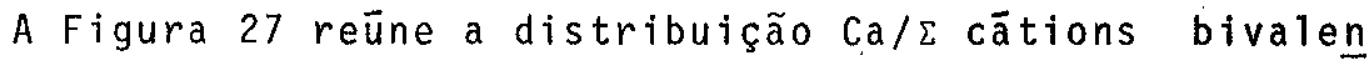
tes de vărios minerais contra a mesma relação dos carbonatos coe xistentes. Essa figura tem o mérito de ressaltar intervalos de porcentagem em peso do Ca, no qual não existem carbonatos e con sequentemente não è plotado nenhum outro mineral.

Nas amostras dos protominērios de Serra do Navio não foram encontrados carbonatos com distribuição de ca maior que 0,56. A rigor, neste caso não se pode falar em intervalo:

Em Buritirama è nitida a falta de carbonatos com valo res $\mathrm{Ca}^{2+} / \Sigma \mathrm{M}^{2+}$ entre 0,52 e 0,75 .

Os dados da Figura 27 auxiliados pela observação dos "trends" vistos nas Figuras 7 e 11 sugerem que os carbonatos de Buritirama dispõem-se de um 1 ado e do outro do "solvus" do siste ma $\mathrm{MnCO}_{3}-\mathrm{CaCO}_{3}-\mathrm{MgCO}_{3}$, desprezando-se o conteüdo de Fe. A pro jeção do "solvus" desse sistema ternärio deve interceptar o 


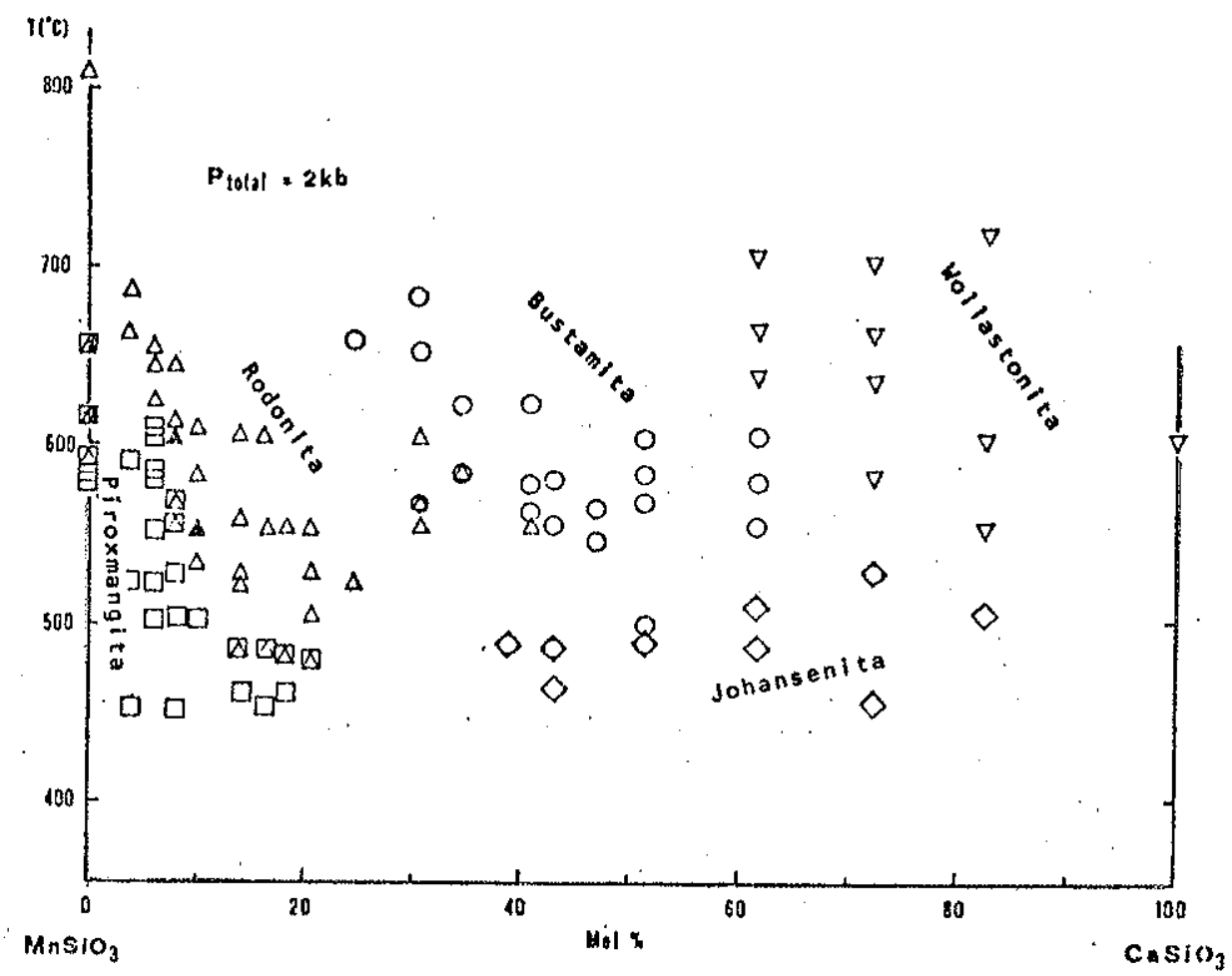

Figura 25 - Resultados experimentais de sintese atravēs da reação $(\mathrm{Mn}, \mathrm{Ca}) \mathrm{CO}_{3}+\mathrm{SiO}_{2}:=$ $(\mathrm{Mn}, \mathrm{Ca}) \mathrm{SiO}_{3}+\mathrm{CO}_{2}$ à $\mathrm{P}$ total $=2 \mathrm{~Kb}$ $\mathrm{X}_{\mathrm{CO}_{2}}$ variando entre 0,3 e 0,6 - Se-gundo ABRECHT \& PETERS, 1975. 


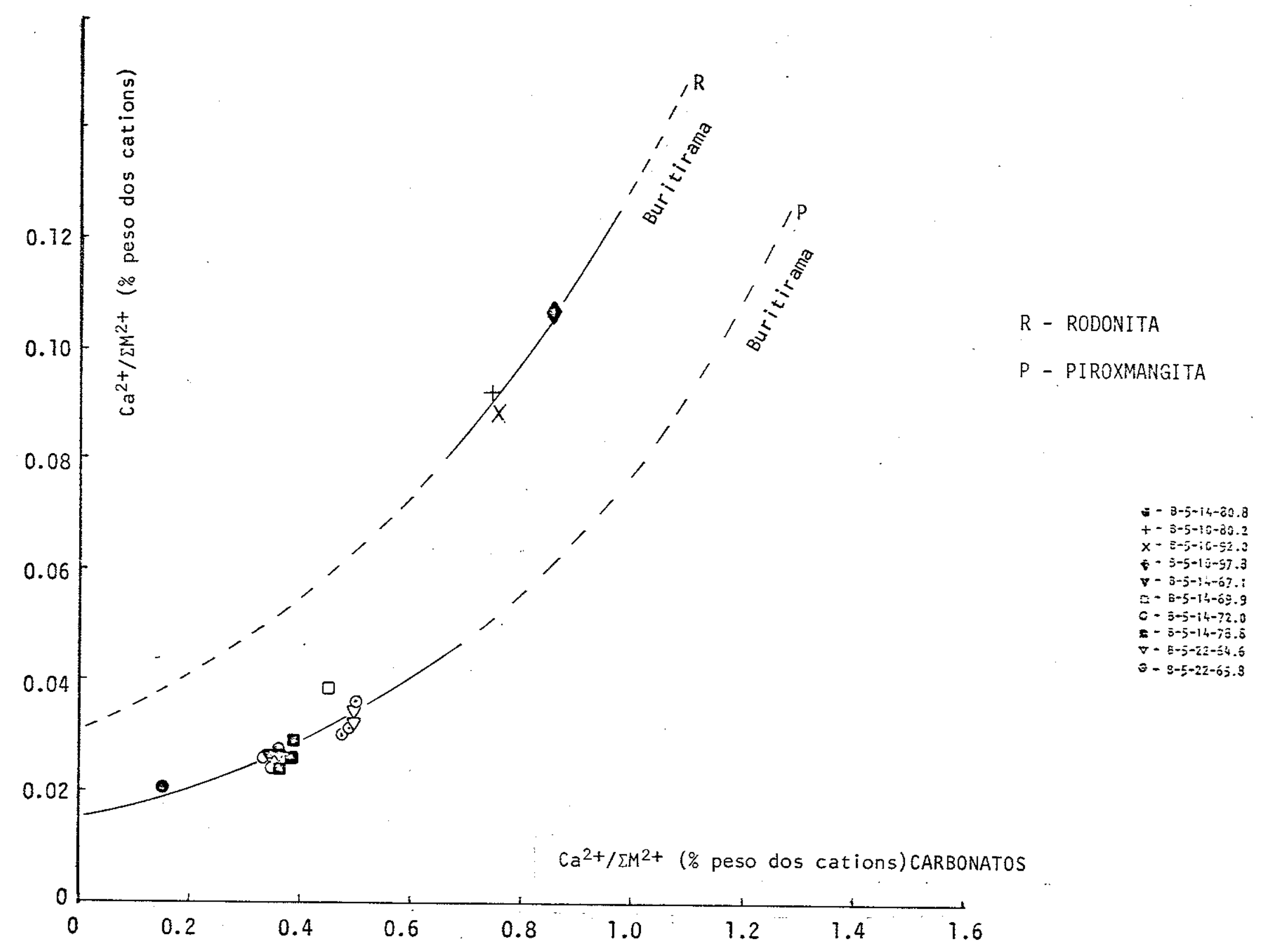

Figura 26 - Distribuição $\mathrm{Ca}^{2+} / \Sigma \mathrm{M}^{2+}$ entre carbonatos e os piroxenöides de Buritirama. 

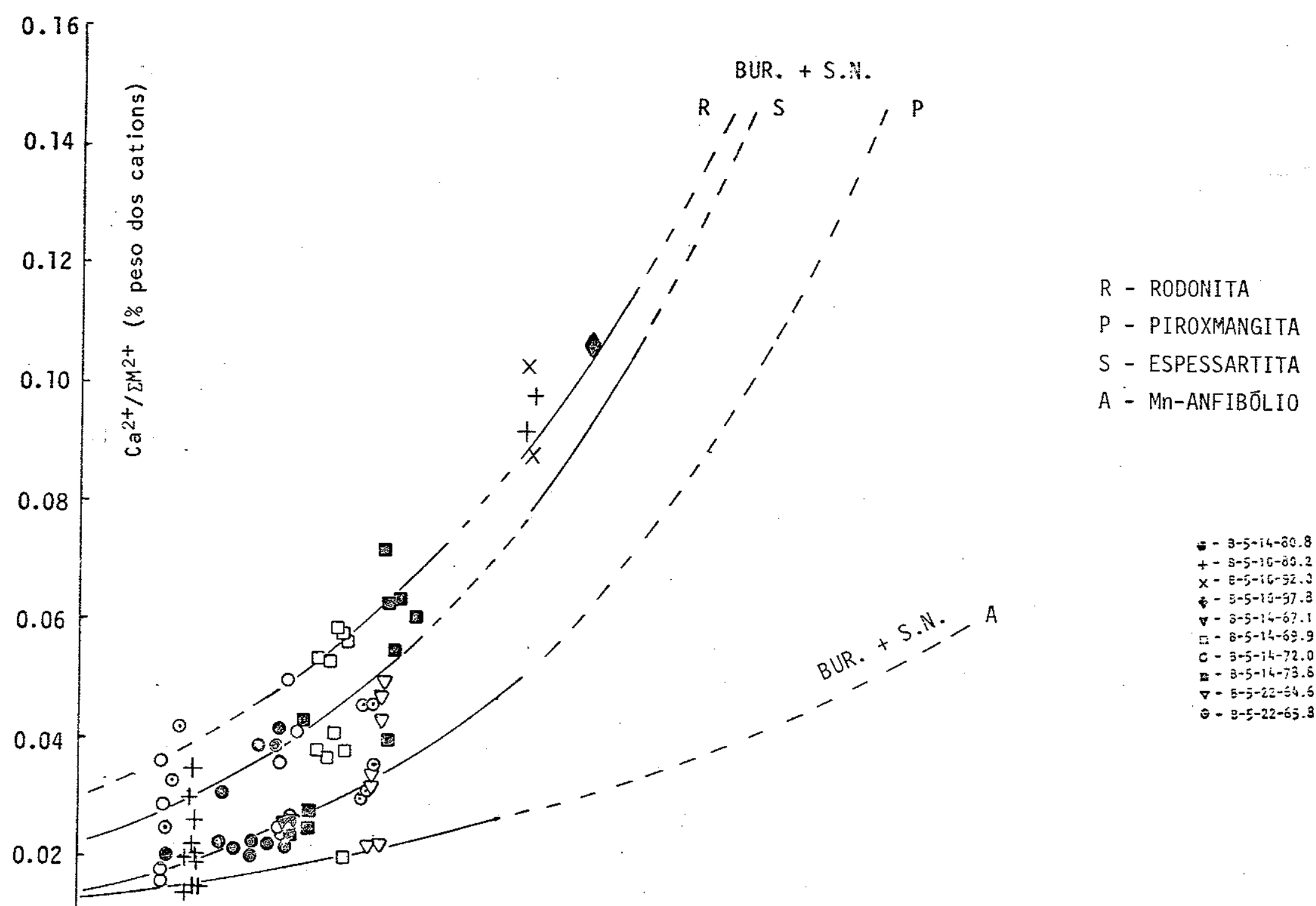

8

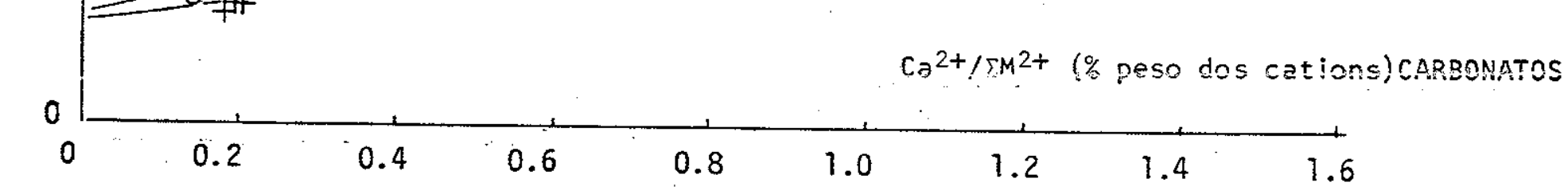

Figura 27 - Distribuição $\mathrm{Ca}^{2+} / \Sigma \mathrm{M}^{2+}$ entre carbonatos e rodonitas, piroxmangitas, espessartitas e anfibölios manganesifferos de Buritirama e Serra do Navio. 
"trend" de composição dos carbonatos nos pontos $\mathrm{Ca}_{0,80} \mathrm{Mn}_{0,18}$ $\mathrm{Mg}_{0,03} \mathrm{CO}_{3}$ e Ca $0,56 \mathrm{Mn}_{0,36} \mathrm{Mg}_{0,08} \mathrm{CO}_{3}$ (ärea calcita-dolomita-kutna horita). Além disso dois carbonatos da amostra B-5-14 - 80,8m não se alinham no "trend" geral sugerindo que talvez tambëm nes te caso tivesse havido influência do "solvus" da ärea compreendi da entre os carbonatos dolomita-kutnahorita-rodocrosita-magnesita.

$\mathrm{Na}$ Figura 27 são interpretados esses fenômenos basea dos nos dados de observação das amostras de Buritirama e nos dia gramas a $500^{\circ} \mathrm{C}$ e $600^{\circ} \mathrm{C}$ de GOLDSMITH \& GRAF (1960). Por esses dá dos mais uma vez confirma-se uma temperatura entre 500 e $600^{\circ} \mathrm{C}$ para o pico do metamorfismo de Buritirama. (Figura 28).

os "trends" de composição dos carbonatos de Serra do. Navio (Figura 11) aproximam-se ma is dos termos magnesianos, "de maneira continua indicando, não tereminterceptado nenhum"solvus" do referido sistema e portanto indicando uma temperatura reinan te maior do que a de Buritirama.

Estes dados são referentes aos protominërios manganes feros sillico-carbonáticos, e as conclusões a respeito das condi ções de $P$ e $T$, diferentes nas duas jazidas, implicam no reconhe cimento do fato que essas paragêneses refletem os picos do meta morfismo, independentemente da existência de um segundo metamor fismo em Serra do Navio, semelhante ao que ocorreu em Buritirama.

Nos märmores manganesifferos e nos protominērios sïlico- carbonáticos sem aluminossilicatos de Serra do Navio, o efeito do segundo metamorfismo restringiu-se a pequenas āreas ou a veios onde foi possivel o caminho de soluções com inversão nos valores das frações molares de $\mathrm{CO}_{2}$ e $\mathrm{H}_{2} \mathrm{O}$. 

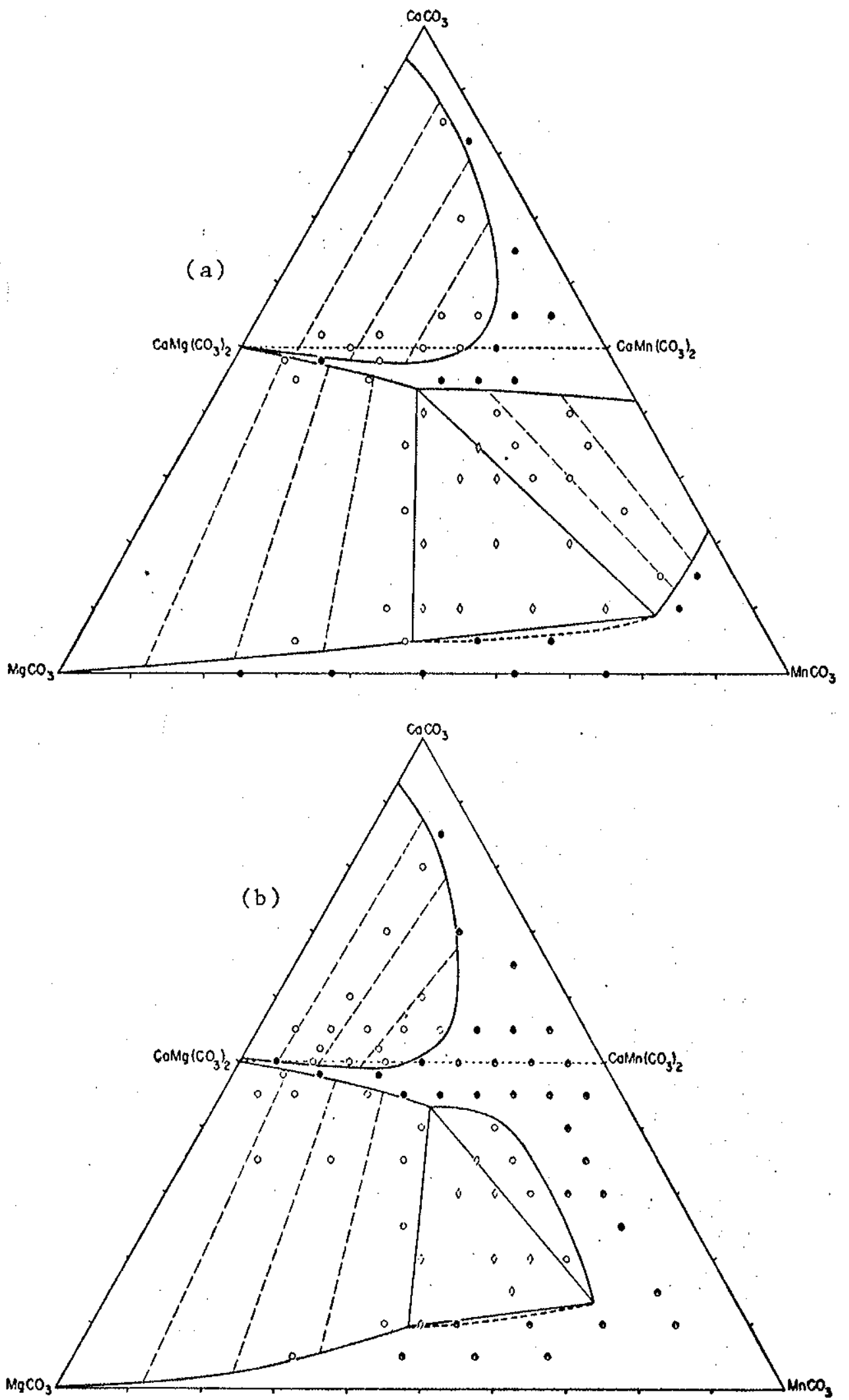

Figura 28, - Soluções sólidas no sistema $\mathrm{CaCO}_{3}-\mathrm{MgCO}_{3}-\mathrm{MnCO}_{3}$ a:

(a) $500^{\circ} \mathrm{C}$ e Pressão total de $10 \mathrm{~Kb}$;

(b) $600^{\circ} \mathrm{C}$ e Pressão total de $10 \mathrm{~Kb}$;

Segundo GOLDSMITH \& GRAF, 1960. 

$\begin{aligned} & V-4 \text { - } \text { CORRELAÇÃO ENTRE O METAMORFISMO, A GEOTECTONICA E A } \\ & \text { GEOCRONOLOGIA }\end{aligned}$

Na Serra de Buritirama ocorre uma sequencia meta-sedi mentar (Grupo Grão Parä) que se sobrepõe discordantemente ao em basamento antigo denominado Complexo Xingu. Em Serra do Navio a situação estratigräfica e semelhante: rochas meta-sedimentares (Grupo Vila Nova) assentando-se sobre o embasamento antigo do Complexo Guianense. Uma ārea pertence ao Craton Guianes e outra ao Craton do Guaporé separados pela Sinēclise do Amazonas, mas ambas pertencentes a Plataforma Amazōnica cuja continuidade $\bar{e}$ assegurada por grandes feições estruturais como: cinturc̄es de do bramentos de metassedimentos, estruturas de fluxo das rcchas ana tecticas dos complexos e feições lineagēnicas motivadas por oro genias e ativações de plataforma (MONTALVAO, 1976).

Ambas regiões pertencem à unidade geo-crono-tectōnica Cinturão Mövel Maroni-Itacaiūnas de idade compreendida $\in$ ntre 1.800 e $2.200 \mathrm{~m} . \mathrm{a}$. (CORDANI et al., 1977 e TASSINARI, 1s78), ci clo orogenētico Transamazōnico.

Em Serra do Navio tem sido obedecida uma estratigrafia local estabelecida por NAGELL (1962) e seguida pelos gecilogos da ICOMI, até SCARPELLI (1973). Trabalhos posteriores ao projeto RADAM (LIMA et al., 1974; CORDANI, 1974; MONTALVAO, 1976; CORDANI et al., 1977; e TASSINARI, 1978), consideram os metassedimentos como pertencentes ao Grupo Vila Nova, antiga Sërie Vila Nova de ACKERMAN (1948) reunida com as ocorrēncias manganesiferás da Ser ra do Navio.

Uma isōcrona Rb/Sr de ectinitos do Grupo Vila Nova (CORDANI, 1974) forneceu idade de $2.090 \mathrm{~m} . \mathrm{a}$. Datações K/Ar dos metassedimentos da Serra do Navio forneceram idades entre 1.710 e $1.770 \mathrm{~m} . \mathrm{a}$. (SCARPELLI, 1973 e HERZ \& BANERJEE, 1973) e 1.800 m.a. (biotita dos xistos encaixantes do protominērio nanganes fero, segundo SCARPELLI, 1968).

A idade Rb/Sr em torno de $2.100 \mathrm{m.a}$. deve corresponder 
ao pico do metamorfismo regional que atingiu temperatura da or dem de $700^{\circ} \mathrm{C}$ e pressões de $5,5 \mathrm{~Kb}$. Apōs um período de resfria mento houve a superimposição de um segundo metamorfismo em con dições de grau médio (fäcies anfibolito), representando um rea quecimento desse cinturão mōvel, concomitantemente com fenôme nos de magmatismo ācido e intermediārio do Grupo vatumã. Os da dos tectōnicos e geocronológicos encontram apoio nas observa ções texturais, paragenéticas e mineralógicas deste trabalho.

Em Buritirama, existe uma isōcrona $\mathrm{Rb} / \mathrm{Sr}$ das rochas do Grupo Grão Pară na região do rio Itacaiūnas fornecendo idade de $1.960 \pm 20 \mathrm{~m} . a$. (GOMES et al., 1975). Ao mesmo tempo esses autores apresentam para um anfibolito da Serra de Buritirama ida des $\mathrm{K} / \mathrm{Ar}$ de $1.961 \pm 31 \mathrm{m.a}$. (amostra 8044 de GOMES et ä..,1975) e de $1.905 \pm 59 \mathrm{~m} . \mathrm{a}$. para as metavulcānicas básicas da serra dos Carajās. Na ārea existe tambēm magmatismo do episōdio llatumã a partir de $1.800 \mathrm{m.a}$. , representado pelo Granito Carajās com isō crona Rb/Sr (TASSINARI, 1978).

os metassedimentos de Buritirama estudados neste tra balho não sofreram reaquecimento, como sugere a concordäncia dos dados geocronológicos $\mathrm{K} / \mathrm{Ar}$ e Rb/Sr e os dados texturais, parage néticos e mineralögicos discutidos anteriormente. 


\section{AGRADECIMENTOS}

Vărias pessoas e instituições prestaram valiosa cola boração para a realização do presente estudo.

A Fundação de Amparo à Pesquisa do Estado de São Pau 10 (FAPESP) colaborou com auxîlio financeiro atravës das bolsas de Mestrado I e II, condição indispensāvel para o bom andamento das pesquisas desenvolvidas.

A Indüstria e Comërcio de Minërios S.A. - ICOMI auxi liou com um grande acervo de testemunhos de sondagem da ärea de Serra do Navio,fator imprescindĩvel para a realização deste es tudo:

A Companhia Meridional de Mineração colocou à disposi. ção seu arquivo de furos de sonda, também condição indispensa vel para a realização de grande parte deste estudo.

o Professor Doutor Jose Vicente Valarelli, do Departa mento de Mineralogia e Petrologia do Instituto de Geociências da Universidade de São Pauto, acompanhou e orientou todas as eta pas deste trabalho, desde a parte experimental até a redação fí. nal, fornecendo seu valioso apoio.

o Professor Doutor José Moacyr Vianna Coutinho, do De partamento de Mineralogia e Petrologia do Instituto de Geociên cias da U.S.P., prestou auxîlio valioso no estudo öptico de sec ções delgadas dos protominérios e encaixantes.

o Professor Doutor Tjerk Peters da Universidade de Berna, contribuiu com discussões e sugestões para melhoria des te trabalho.

o Professor Doutor J. Sommerauer, foi o responsāve1 pelos dados de microssonda eletrônica obtidos nos laboratórios do ETH, Instituto de Cristalografia de Zurich.

o Professor Doutor Jurgen von Raumer colaborou, junta mente com o Professor Doutor Josë Vicente Valarelli, com estu 
dos de inclusões fluidas em grãos de quartzo realizados nos labo ratórios de Mineralogia de Fribourg, Suiça.

0 Professor Rainer Shultz do Departamento de Mineralo gia e Petrologia do Instituto de Geociēncias, USP, forneceu aux $\bar{i}$ lio valioso para o enriquecimento de parte dos estudos.

0 Professor Doutor Raphael Hypölito do Departamento de Mineralogia e Petrologia do Instituto de Geociências, USP, pres tou sua colaboração para a melhoria do texto.

0 Professor Doutor Umberto G. Cordani e o Geólogo Co lombo Tassinari contribuiram com discussões de dados geocronolö gicos das duas äreas estudadas.

o Geōlogo Jorge Kazuo Yamamoto efetuou anālises esta tîsticas dos dados de microssonda eletrônica, contribuindo para o estudo da partição de elementos, utilizando computador eletrô nico do Instituto de Pesquisas Tecnolögicas onde trabalha.

o Senhor Paulo Mori e Senhor João Batista de Souza do Departamento de Mineralogia e Petrologia do Instituto de Geociēn cias, USP, prestaram sua colaboração com a obtenção de numerosos difratogramas e filmes de raios $X$.

Os Senhores Jaime de Souza Marcos, Luiz Alberto veira Bello e a Senhora Maria Antonieta G. Bello foram os res ponsāveis pela revelação e ampliação de parte das fotografias presentes no texto.

A Senhora Nair de Campos Louzada e os Senhores Jose Ponchirolli e Jayme Alves da Silva são os responsāveis pela dati lografia, paginação e impressão deste trabalho.

A Senhora Melany Thereza Isauk auxiliou com a confec ção das secções delgadas utilizadas neste estudo.

A todas as pessoas citadas que forneceram sua colabora ção, bem como as näo mencionadas que deram seu apoio e auxilio a realização deste estudo, a autora mostra-se profundarente re conhecida e expressa seus melhores agradecimentos. 


\section{BIBL IOGRAFIA}

ABRECHT, J. \& PETERS, Tj. - 1975 - Hydrothermal synthesis of pyroxenoids in the system $\mathrm{MnSiO}_{3}-\mathrm{CaSiO}_{3}$ at $\mathrm{Pf}=2 \mathrm{~Kb}$. Contrib. Mineral. Petrol. 50: 241-246.

ACKERMANN, F.L. - 1948 - Recursos minerais do Territörio Federal do Amapä.. Imp. Naciona 1, 30 .

ANDERSON, W.L., DYER, R.C. \& TORRES, D.D. - 1974. Ocorrências de manganès na Bacia do Rio Itacaiunas, Centro-Leste do Estado do Pará. Anais do XXVIII Congr. Bras. Geol., $6: 149-164$.

BARBOUR, A.P. - 1965 - Resumo da geologia dos depōsitos de manga nês de Serra do Navio. Ind. e Com. de Minērios S.A. ICOMI, $10 \mathrm{pp}$. (inēdito).

BEISEGEL, W.R., BERNARDELLI, A.L., DRUMMOND, N.F., RUFF:A.W. \& TREMAINE, J.W. - 1973 - Geologia e recursos minerais da Serra dos Carajäs. Rev.Bras.Geoc., 3 (4): 215-242.

BELLO, R.M.S., CANDIA, M.A.F., COUTINHO, J.M.V. \& VALARELLI, J.V. - 1976 - 0corrência simultânea de piroxmangita e rodo nita em protominērios de manganês brasileiros. XXIX Congr.Bras.Geol., Belo Horizonte, Resumos, p. 315.

BITTENCOURT, A.V.L. - 1973 - Contribuição ao estudo genëtico do minērio de manganês de Conselheiro Lafaiete, MG. Dis sertação de Mestrado apresentada ao Instituto de Geo. ciências da Universidade de São Paulo, $81 \mathrm{pp}$.

CASTRO, L.0. - 1963 - Study of the manganese ore deposit of the Serra do Navio District - Amapā, Brazil. Term. Paper, Stanford University, 1960. Rev.Bras.Geo1., 12 (1): 5-35 .

CHATTERJEE, N.D: \& JOHANNES, W. - 1974 - Thermal stability and standard termodynamic properties of synthetic $2 \mathrm{Ml}$ Muscovite, $\mathrm{KAl}_{2}\left[\mathrm{AlSi}_{3} \mathrm{O}_{10}(\mathrm{OH})_{2}\right]$ Contr.Mineral.Petrol., 48: 89-114 (in M. Frey 74/75). 
CORDANI, U.G. - 1974 - Comentärios - Amapä. Projeto RADAM (inē dito).

CORDANI, U.G., BASEI, M.A.S., TASSINARI, C.C.G., TEIXEIRA, W. \& KAWASHITA, K. - 1977 - Outline of the Precambrian tectonic provinces in the Amazonian Region. V Congres so Venezuelano de Geologia.

COUTINHO, J.M.V., PETERS, Tj., CANDIA, M.A.F. \& VALARELLI, J.V. - 1976 - Mineralogical study of the main manganese carbonate silicate protores (queluzites) from Brazil and their weathering products. $25^{\text {th }}$ International Geo logical Congress, Sydnei, Australia. Abstracts 3: 764-765 .

CURRIE, K.L. - 1971 - The Reaction 3 cordierite $=2$ garnet +4 sillimanite +5 quartzo as a geological thermometer in the opinicon Lake region, Ontario. Contr.Miner.Petrol., 33: 215-216 (in WINKLER, 1976).

DEER, W.A., HOWIE, R.A. \& ZUSSMAN, J. - 1963 - Rock forming minerals. William Clowes and Sons., Ltda., London.

DORR, J.V.N., HOREN, A. \& COELHO, I.S. - 1958 - Jazidas de man ganês de Minas Gerais, Brasil. DFPM, Bol. 105, $95 \mathrm{pp}$.

EBERT, H. - 1963 - The Manganese - bearing Lafaiete - Formation as a guide horizon in the Precambrian of Minas Gerais. An.Acad.Bras.Ciēnc., XXXV (4): 545-559.

FREY, M. - Gesteinsmetamorphose. Skriptum ws 74/75. Min. Petr. Institut der Uni. Bern, $139 \mathrm{pp}$.

GIRARDI, V.A.V., COUTINH0, J.M.V. \& VALARELLI, J.V. - 1965 - E $\underline{s}$ tudo ōptico e roentgenográfico das cordieritaś de Pau linia, SP e Serra do Navio, Amapā. Congr. SBPC, Belo Horizonte. Ciëncia e Cultura, 17 (2): 133-134.

GOLDSMITH, J.R. \& GRAF, D.L. - 1957 - The system CaO-MnO-CO 2 : Solid-solution and decomposition relations.Geochimica et Cosmochimica Acta, 11: 310-334.

GOLDSMITH, J.R. \& GRAF, D.L. - 1960 - Subsolidus reitations in the system $\mathrm{CaCO}_{3}-\mathrm{MgCO}_{3}-\mathrm{MnCO}_{3}$. Journal of Geology, 68: $324-335$. 
GOMES, C.B., CORDANI, U.G. \& BASEI, M.A.S. - 1975 - Radiometric ages from the Serra dos Carajäs area, Northern, Bra zi1. Geol.Soc.America Bu11., 86: 939-942.

HENSEN, B.J. - 1971 - Theoretical phase relations involving cordierite and garnet in the system $\mathrm{MgO}-\mathrm{FeO}-\mathrm{Al}_{2} \mathrm{O}_{3}-\mathrm{SiO}_{2}$. Contr.Miner.Petr., 33: 191-194.

HENSEN, B.J. \& GREEN, D.H. - 1971 - Experimental study of cordierite and garnet in pelitic compositions at high pressures and temperatures. I - Compositions with excess aluminosilicate. Contr.Miner. Petr., 33: 309-330 .

HENSEN, B.J. \& GREEN, D.H. - 1972 - Experimental study of cordierite and garnet in pelitic compositions at high pressures and temperatures. II - Compositions without excess aluminosilicate. Contr. Miner.Petr., 35: 331-334.

HENSEN, B.J. \& GREEN, D.H. - 1973 - Experimental study of cordierite and garnet in pelitic compositions at high pressures and temperatures. III -. Synthesis of experimental data and geological aplications. Contr. Miner. Petr., 38: 151-166.

HERZ, N. \& BANERJEE, S. - 1973 - Anfibolites of the Lafaiete, Minas Gerais, and the Serra do Navio manganese deposits, Brazil. Econ. Geo1., 68: 1289-1296.

HOFFER - personal comunication, 1975 (in WINKLER, 1976, p.224). HOSCHEK, G. - 1969 - The stability of staurolite and chloritoid and their significance in metamorphism of pelitic rocks. Contr.Min.Petr. Mitt, 20: 48-58 (in M. Frey$74 / 75)$.

HURLEY, P.M., ALMEIDA, F.F.M. de, MELCHER, G.C., CORDANI, U.G., RAND, J.R., KAWASHITA, K., VANDOROS, P., PENSON Jr., W.H. \& FAIRBAIN, H.W. - 1967 - Test of Continental Drift by comparison of radiometric ages. Science 157 $(3788): 495-500$. 
KENNEDY, G.C. - 1954 - Pressure - Volume - Temperature relations in $\mathrm{CO}_{2}$ at elevated temperatures and pressures. Amer. Journa1 Science, 252: 225-241.

KERN, M.R. \& WEISBROD, M.A. - 1964 - Termodynamic de base pour minēralogistes, pëtrographes et gëologues. Mas'son et: $c^{i e}$, Editeurs, 120, boul. Saint Germain, Paris (Vie); $243 \mathrm{pp}$.

LANDOLF-BOERNSTEIN - 1960 - Tables - Springer Verlag, Berlin- Gottingen-Heidelberg.

LEINZ, V. - 1948 - Estudo genētico do minērio de manganēs da Serra do Navio, Territōrio do Amapā. Acad.Bras. Ciēn., 20 (2): 211-221, Rio de Janeiro.

LIMA, M.I.C. de, MONTALVAO, R.M.G. de, ISSLER, R.S., OLIVEIRA, A. da S., BASEI, M.A.S., ARAUJ0, J.F.V. \& SILVA, G.C. da - 1974 - Geologia da Folha NA/BA. 22 Macapä. In Brasil DNPM - Projeto RADAM. Folha NA/NB. 22, Macapa (Levantamento de Recursos Naturais, 6).

MAROTTA, C.A., SCARPELLI, W., MARUO, J., BARBOUR, A.P., LIMA,L. G.B. - 1963 - Notas sobre o distrito manganesifero de Serra do Navio, Territörio Federal do Amapä, Brasil. Anais da VI Conferência Geolögica das Guianas e DNPM Avulso $41: 57-59,1966$.

MELFI, A.J. \& PEDRO, G. - 1973 - Etude sur l'altëration expērimentale de silicates manganēsiferes et la forma tion exogene des gisements de manganese. Bul1.Groupe franç. Argiles. $t$ XXVI: 91-105.

MONTALVÃo, R.M.G. de - 1976 - Esboço geolögicontectōnico do Cräton Guianês. Rev.Bras.Geoc., 6 (4): 230-245. NAGELL, R.H. - 1962 - Geology of the Serra do Navio manganese district, BraziT. Econ.Geol., 57: 481-498.

PARK, C.F., Jr. - 1956 - Manganese ore deposits of the Serra do Navio district, Federal Territory of Amapä, Erazil. $X X$ Int. Geol. Congr., Mexico, III: 347-376.

PETERS, Tj., VALARELLI, J.V. \& CANDIA, M.A.F. - 1974 - Petrogenetic Grids on the system Mn-Si-C-0-H. Rev.Bras.Geoc. 4 (1): 15-26. 
RIBEIRO FILHO, E. - 1968 - Geologia da região de Urandi e das jazidas de manganés Pedra Preta, Barreiro dos Campos e Barnabé, Bahia. Tese apresentada ao concurso de Li vre Docência da Faculdade de Filosofia, Ciências e Lé tras da Universidade de São Paulo, $83 \mathrm{pp}$.

RICHARDSON, S.W. - 1968 - Staurolite stability in a part of the system Fe-Al-Si-0-H. J.Petr. 9: 467-488.

SCARPELLI, W. - 1963 - Aspectos genéticos e metamōrficos das ro chas do Distrito de Serra do Navio, Território Federal do Amapā, Brasil. VI Conferência Geológica das Guianas, e DNPM Avulso no 41: 37-56, 1966.

SCARPELLI, W. - 1968 - Precambrian metamorphic rocks of Serra do Navio, Brazil, unpublished work. Stanford University, $50 \mathrm{pp}$.

SCARPELLI, W. - 1973 - The Serra do Navio manganese district (Brazil). Genesis of Precambrian iron and manganese deposits. Proc. Kiev: Symposium, 1970. Earth Sciences, 9: 217-222. Paris UNESCO.

SIlVA, A.R., SCARPElli, W., MARotTA, C.A. - 1961 - Contribuição ao estudo dos protominêrios de manganēs do distrito de Serra do Navio, Território Federal do Amapā. Anais XV Congr.Bras.Geol., Florianöpolis e Rev.Bras. Geol., 12 (1): $37-48,1963$.

SKIPPEN, G.B. - 1967 - An experimental study of the metamorphism of siliceous carbonate rocks. A dissertation submitted to the Johns Hopkins University in conformity with the requirements for the degree of Doctor of Philosophy. Baltimore, Maryland, $251 \mathrm{pp}$.

SKIPPEN, G.B. - 1974 - An experimental model for low pressures metamorphism of siliceous dolomitic marble. Aner. J. Sci. 274: 487-509.

TASSINARI, C.C.G - 1978 - Comunicação pessoal. 
THOMPSON, J.B. \& NORTON, S.A. - 1968 - Paleozoic regional metamorphism in New England and adjacent areas. In E-An Zen et al., eds. Studies of Appalachian Geology. Interscience Publisher (John Wiley \& Sons), New York. (in WINKLER, 1976, p. 223).

TOLBERT, G.E., TREMAINE, J.W., MELCHER, G.C. \& GOMES, C.B. - 1971 - The recently discovered Serra dos Carajás iron deposits, Northern Brazil. Econ.Geol., 66: 985-994.

TOLBERT, G.E. - 1973 - Geology and iron deposits of Serra dos Ca rajäs, Parā, Brazil, in Genesis of Precambrian iron and manganese deposits: UNESCO symposium, Kiev, 1970, Proc.: $271-280$.

VALARELLI, J.V. - 1963 - Contribuição a mineralogia do minërio de manganês da Serra do Navio, Amapă. Anais da VI Con ferência geológica das Guianas e DNPM, Avulso no 41: 83-98, 1966.

VALARELli, J.V. - 1967 - 0 minërio de manganēs da Serra do Navio, Amapä. Tese de Doutoramento apresentada a Faculdade de Filosofia, Ciências e Letras da Universidade de São Paulo, $149 \mathrm{pp}$.

VALARELLI, J.V. - 1975 - La 1 ithiophorite de 1 a Serra do Navio, Amapā, Brësil. Bu71. suisse Minëral. Petrogr. 55: 19-30 .

VALARELLI, J.V. - 1977 - Relatōrio sobre o minërio de manganēs do Azu1, $104 \mathrm{pp}$. (inëdito).

VALARELLI, J.V., COUTINHO, J.M.V. \& CANDIA, M.A.F. - 1976 Paragenetic relations among carbonates, olivines and pyroxenoids in metamorphic carbonate silicate manganese protores from Brazil. III Congr. Latinoamericano de Geo logia, México, Resumos, p. 142.

VALARELLI, J.V. \& CROSTA, A.P. - 1977 - Sintese de silicatos e alumino silicatos manganesíferos. Relatórios de Bolsa de Iniciação Cientîfica, FAPESP.

WINKLER, H.G.F. - 1976 - Petrogenesis of Metamorphic Rocks Springer-Verlag New York, Heidelberg, Berlin: 112-128; 202-233. 